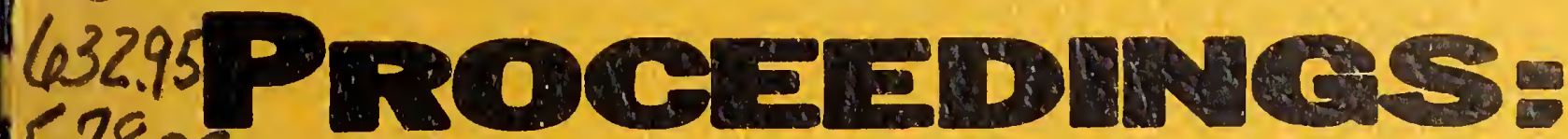
E78ps

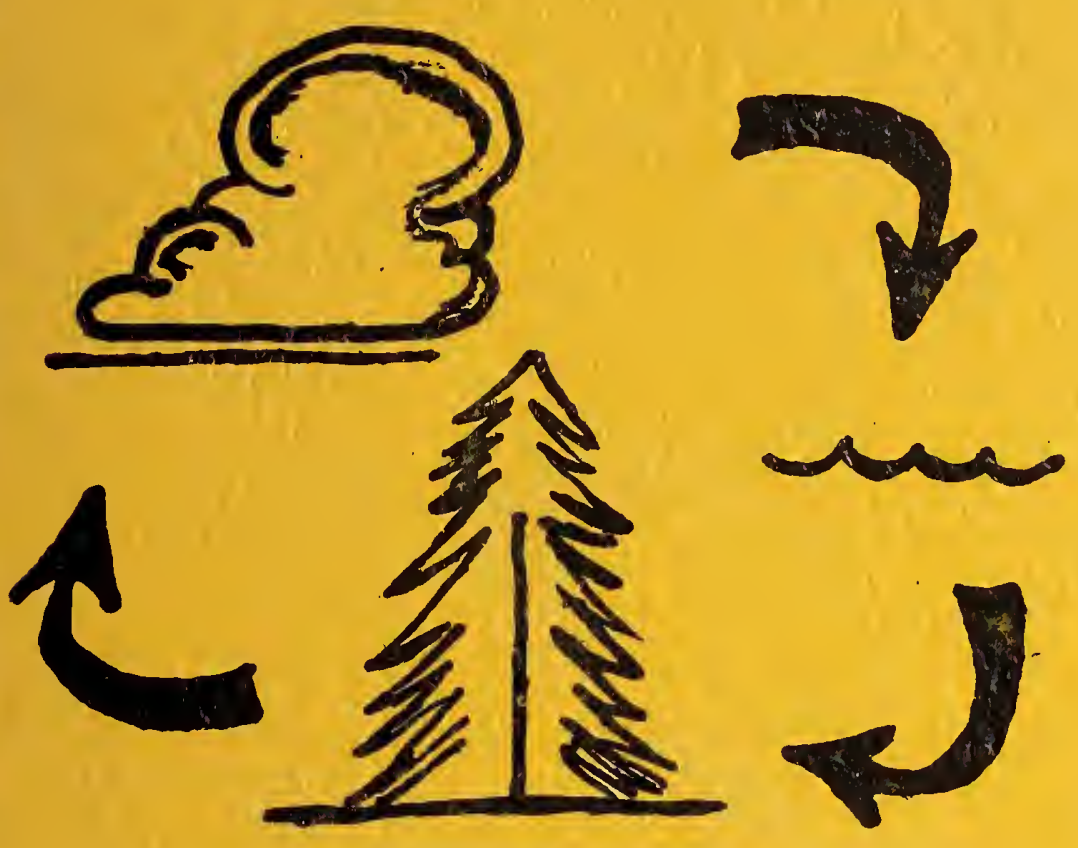

APP 27076

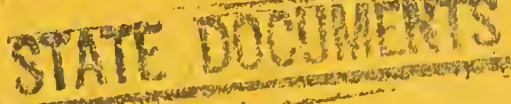

seminar.
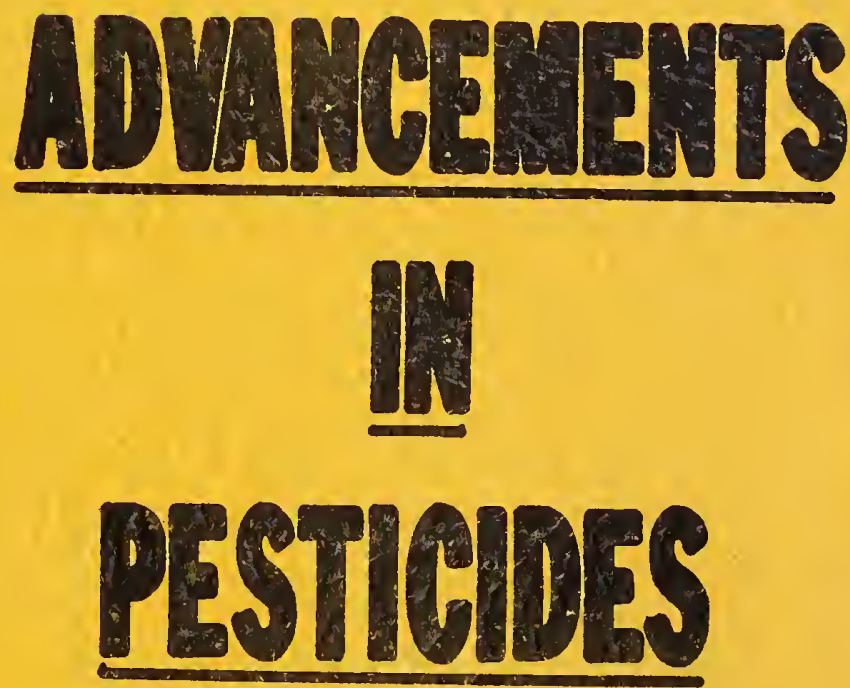

\title{
Sept. $16-18,1975$
}

State Department of Health and Environmental Sciences Environmental Sciences DivisioneSolid Waste Management BureauoPesticides Demonstration Program 
Advancements in pesticides :seminar, Sep |H|W| ||W|

Qt: 10 . dot 30864000205412 


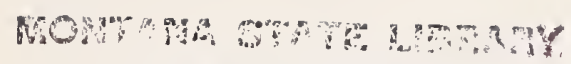

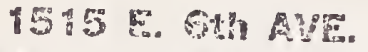

MELENA, MONTANA 59620

The Montana Pesticide Demonstration Program is supported by contract no. 68-01-2979 with the Air and Hazardous Materials Division, Pesticides Branch, Region VIII, EPA, Denver, Colorado 
Digitized by the Internet Archive in 2016 
1.

1. Speaker List... . . . . . . . . . . . . . . . . . . iv

2. Participant List. . . . . . . . . . . . . . . . . . . . vi

3. Keynote Address. . . . . . . . . . . . . . . . . . . . . . 1 Kit C. Walther

4. Insect Pest Management - The Thinking Man's Pest Control . . . . . . . 5 Leon Moore, Ph.D.

5. Nosema locustae: An Alternative Method of Grasshopper Control . . . . . 16 John E. Henry, Ph.D.

6. Advancements in Herbicides . . . . . . . . . . . . . . . . 29

L. E. Warren

7. Di lemma for Disposal of Herbicide Orange . . . . . . . . . . . . 65 Capt. Alvin L. Young, Ph.D.

8. A Plan for Determining Waste Pesticide Disposal Practices in EPA Region VIII.............................. Gary J. Mihlan

9. Political Factors in Animal Damage Control ............... 100 Dale A. Wade, Ph.D.

10. Control of Noxious Plants Through the Application of Rest Rotation Grazing Management . . . . . . . . . . . . . . . . . . . . . Harry R. Gosgriffe

11. Remarks by Hurlon Ray, OFFICE OF PESTICIDES, to the Seminar, Advancements in Pesticides . . . . . . . . . . . . . . . . . . . 13 Hurlon Ray

12. Effects of Sagebrush Control on Wildlife and Ecosystem Components Results of a Ten Year Study. . . . . . . . . . . . . . . . 145 Eugene 0 . Allen

13. Integrated Pest Management . . . . . . . . . . . . . . . . 170 Dallas Miller

14. Some Future Pest Control Methods . . . . . . . . . . . . . . . . . 177

L. Hopkins, Ph.D.

15. Zinc Phosphide - A Control Agent for Black-Tailed Prairie Dogs . . . . 189 Howard P. Tiet jen

16. Registration Procedures and Evaluation ............... 190 Herbert S. Harrison

17. Re-entry Studies in Washington Orchards and Monitoring Pesticides in the Columbia River Basin . . . . . . . . . . . . . . . . . 200 Lynden P. Baum

18. Discussions by Speakers not Submitting a Presentation for the Proceedings. 206 
1. Dipel $\mathbb{B}$ as a Control Agent for Western Spruce Budworm ilark D. McGregor

2. Efficiency of Seven 4-0il and Dylox for Control of Western Spruce Budworm Tom Flavell

3. EPA State Ass istance Programs James Boland - Ed Stearns

4. Degradation of Pesticides in the Soil

D. D. Kaufman, Ph.D.

5. Use of Strychnine Alkaloid for Striped Skunk (Mephitis mephitis) Rabies Control and Surveillance in Eastern Montana Gary Nesse

6. Experimental Use of Sodium Cyanide Spring Loaded Ejector Mechanism (M-44) for Predatory Animal Control in Montana

Ken Seyler

7. Pesticide Incineration

Thomas L. Ferguson

8. Montana Applicator Certification Plan

Gary L. Gingery

9. EPA Disposal Activities

Harry W. Trask 
Eugene 0 . Al len

Lynden Laum

Jimi joland

Thomas L. Ferguson

Tom Flavell

James H. Gillett, Ph.o.

Gary L. Gingery

ilarry R. Gosgriffe

Herbert Harrison

John E. Henry, Ph.D.

Lemac Hopkins, Ph.D.

D. D. Kaufman, Ph.D.

Mark D. McGregor

Gary J. Mihlan

Dallas Miller
Chief, Wildlife Research Section, Research Park Bldg., Department of Fish \& Game, State University, Bozeman, Montana

Pesticide Consultant, Washington State Health Services Division, Chemical Physical \& Radiological liazards Section, lenatchee, Vashington

Operations Division, Office of Pesticide Programs, EPA, Vashington, D.C.

Senior Chemical Engineer, Hidwest Research Institute, Kansas City, II issouri

Leader, Pilot Project Group, Division of State E Private Forestry, Environmental Protection, Rezion, 1, USFS, Mis soula, liontana

llational Environmental Research Center, Corvall is, Oregon

Administrator, Pesticides Control Division, Department of Agriculture, Helena, Hontana

Range Conservationist, Bureau of Land Management, Department of Interior, Billings, Montana

Uranch Chief, Registration Evaluation Branch, Registration Division, EPA, lashington, D.C.

Research Entomologist, Rangeland Insect Laboratory, Montana State University, Bozeman, Montana

Technical Advisor, Environmental Qual ity Chevron Chemical Company, San Francisco, California

Nicrobiologist, Pesticide Degradation Laboratory, Agricultural Environmental Quality Institute, Agricultural Research Center, Beltsville, Maryland

Entomologist, Division of State \& Private Forestry, Environmental Protection, Region 1, USFS, Missoula, Montana

Research Associate, Institute of Rural Environmental Heal th, Colorado Epidemiologic Pesticide Studies Center, Colorado State University, Fort Collins, Colorado

State Program Mlanager, State Assistance Section, Pesticides Branch, Air \& Hazardous Materials Division, Region VIII, Denver, Colorado 
Leon Moore, Ph.D.

Gary Nesse

Hurlon Ray

Kenneth Seyler

Edward L. Stearns

Howard Tietjen

Harry W. Trask

Dale A. Wade, Ph.D.

Kit C. Walther

L. E. Warren

Capt. Alvin L. Young, Ph.D.
Associate Professor and Extension Entomologist, Cooperative Extension Service, University of Arizona, Tucson, Arizona

Predatory Animal \& Rodent Control Biolosist, Central District Predatory Animal - Rodent Control Bureau, Department of Livestock, Lewistown, Montana

Special Assistant for the Deputy Assistant Administrator of Pesticide Programs, Washington, D.C.

Chief, Predatory Animal - Rodent Control Bureau, Department of Lives tock, Helena, Montana

State Program Manager, State Assistance Section, Pesticides Branch, Air \& Hazardous Materials Division, Region VIII, EPA, Denver, Colorado

U. S. Fish \& Wildlife Service, Denver Wildlife Research Center, Denver, Colorado

Program Manager, Pesticide Disposal \& Storage, Hazardous Was te Management Division, EPA, Washington, D.C.

Extension Wildi ife Specialist, Agricultural Extension, University of California, Davis, Cal ifornia

Pesticide Disposal Demonstration Prograri, Sol id laste Management Dureau, Department of iiealth and Environriental Sciences, Helena, Hontana

Field Research and Development, Ag-Jrganics Department, Dow Chemical Company, Davis, Cal ifornia

Associate Professor Life Sciences, Department of Life and Beinavioral Sciences, Department of the Air Force, USAF Academy, Colorado 


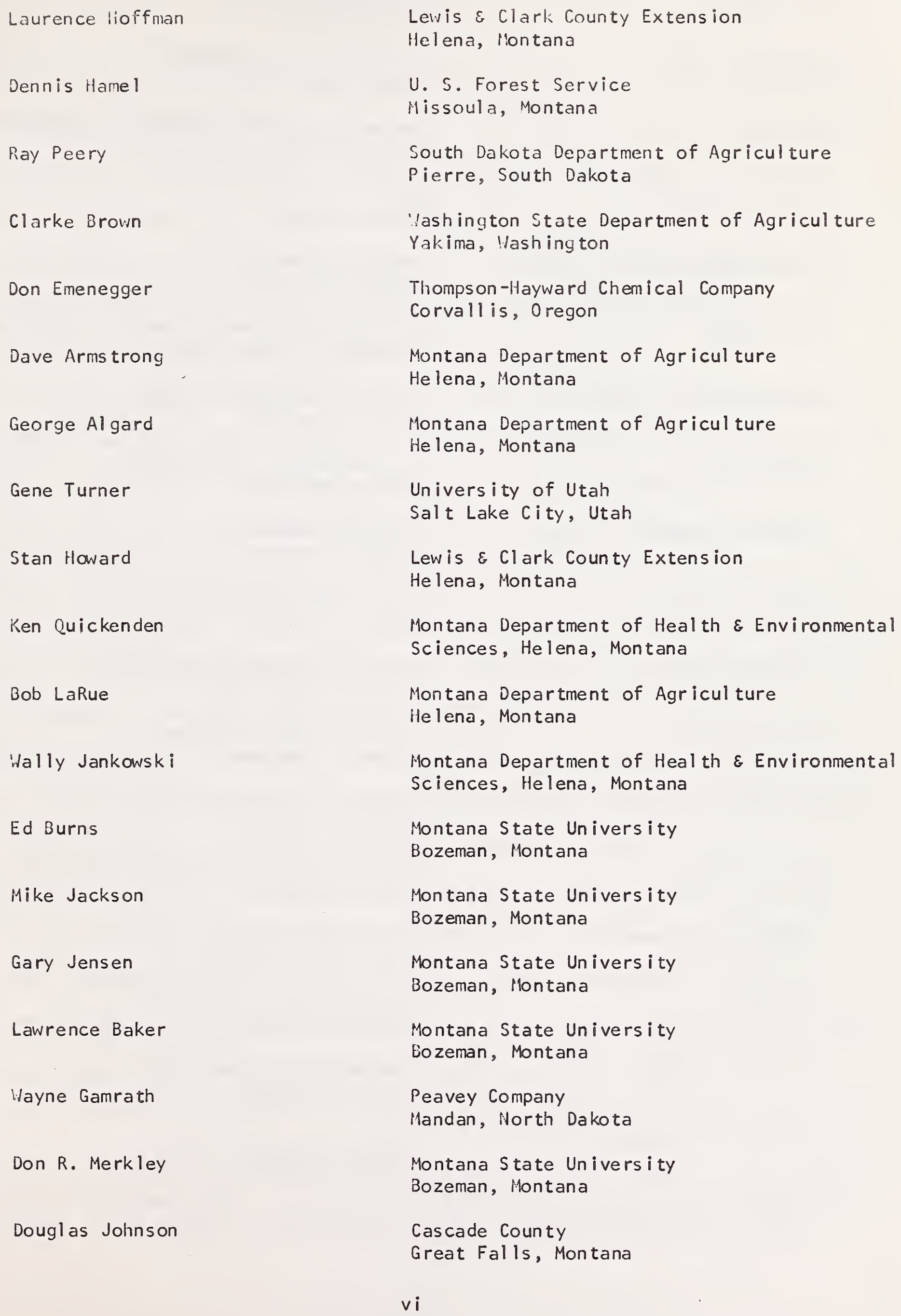




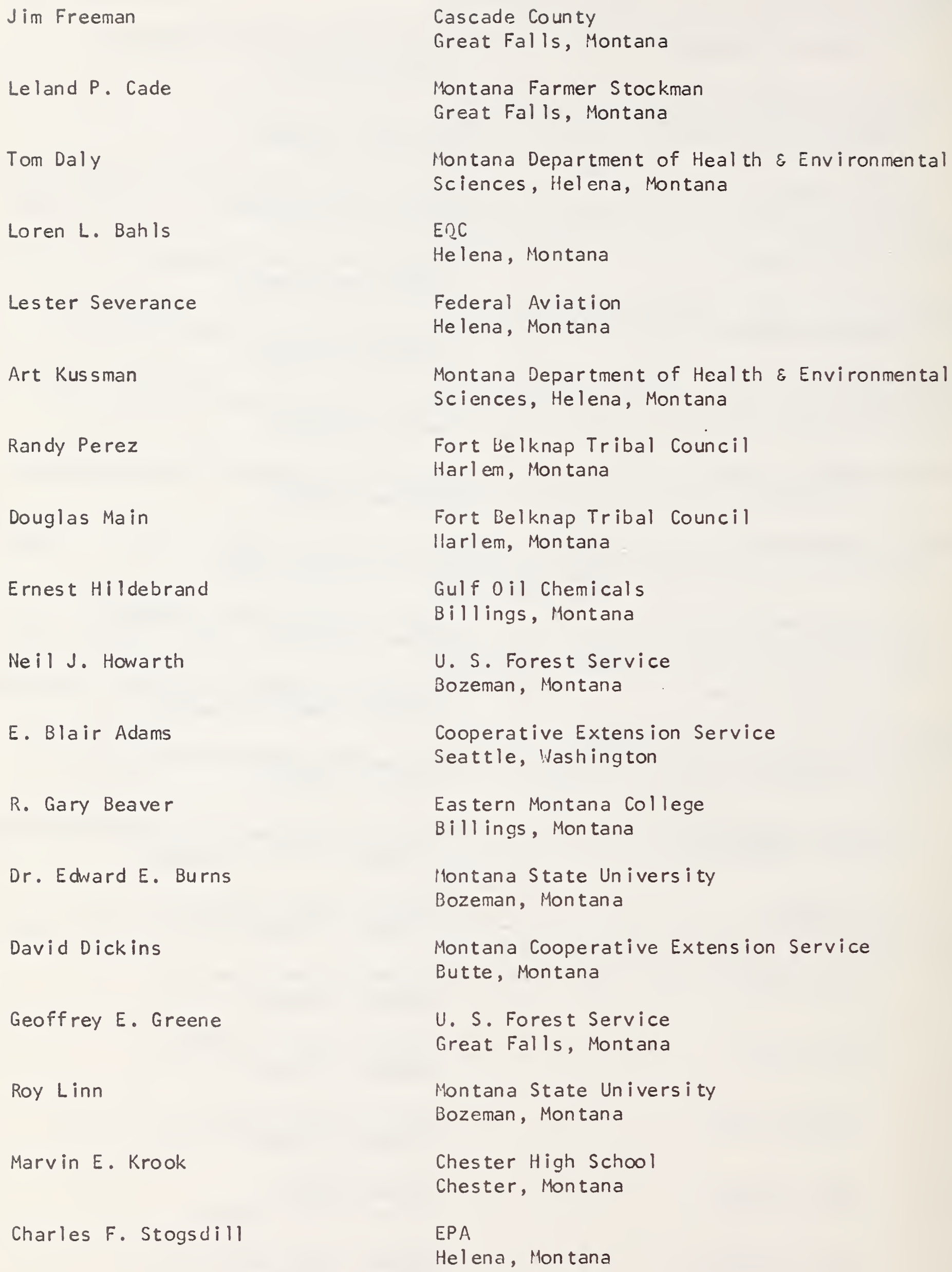


There are continued national and global pressures for more effective pest control strategies to provide for expanding population needs and to have these methods more compatible with environmental quality. Progress to meet these overwhelming demands will be made in only two ways: by developing new pest control strategies or by evaluating and refining the pest control strategies presently available. In either event, the success of new, as well as old, pest control strategies for the future is dependent upon public support and understanding.

In the last decade, a serious credibility gap has developed between the pesticide industry and the public, creating a cris is of confidence in the use of chemical pesticides. Ironically, in the face of this public lack of confidence, pesticides remain our only first line of defense, even in the integrated control strategies. Further, we are assured that chemical pesticides will continue to play a major role in the future strategies for pest control. The development of pest control strategies has also come at a time when public sentiment for research and technology have peaked and are at a decline. These are difficult odds at best, for those involved in mapping pest control strategies. Continued lack of public support may drive away industry incentive to develop new environmentally compatible chemicals and may hinder long range pest control research vital to pest strategy planning. Neither industry or government can neglect the challenge to close this credibility gap. Both must reach mutually agreeable goals which are openly honest with the public's wishes.

After more than a decade of debate, the public has concluded that pesticides constitute a serious threat to the environment. Earlier this concern was for human health and later broadened to include environmental concerns. The issue focused chiefly on DDT, and the evidence of its role in environmental pollution formed the

Presented by Kit C. Walther, Project Coordinator, Pesticides Demonstration Program, Solid Waste Management Bureau, Department of Health and Environmental Sciences at the Seminar, "Advancements in Pesticides", Helena, Montana, September 16, 1975. 
basis for the controversy. Unfortunately, the conclusion drawn about DDT have tended to become generalizations about all pesticides by much of our public, environmental organizations, and many governmental agencies.

Nevertheless, we learned some valuable lessons from the DOT controversy:

- The conventional wisdom underlying the practice of chemical control in the DDT days was unsound.

- Some characteristics of the pests and the molecules being directed at them were not properly assessed.

It was found that the initial successes of chemical control with synthetic organic insecticides led to a sense of false security and oversimplification in assessing the nature of the problem. The development of insect resistance, the resurgence of target species, and the disruption of nontarget species was never anticipated, nor was the practical significance of chemical stability, lipid solubility and broad spectrum toxicity. The interrelatedness of the biosphere was never fully appreciated until the mobility of DDT and its accumulation in living organisms were disclosed.

There were three strategic errors in the designing of molecules for pest control previous to 1940. They were the following: the search for lipophilicity to promote rapid permeation of the living cell; unconcern for absorption to soil colloids and organic matter; and a conscious effort to choose a wide spectrum activity so as to secure as large a market as possible.

These errors in judgement in the underlying strategy of chemical control are readily acknowledged by many concerned pest control specialists, but have actually had a most positive effect on the field of pest control. These setbacks led to new thinking about the biochemistry of the species, genetic mechanisms, behavior, and a host of other matters that relate to population dynamics, pest management, and chemical development. 
The past three decades has resulted in the emergence of a new concept of pest control centering on population dynamics as the framework. From the understanding of the factors regulating pest populations, a number of pest control practices are invoked, that in total reduce the population to tolerable levels. This concept deemphasizes primary reliance on a single method of control and the anticipated objective of complete control or pest-eradiction. Al though the method does not eliminate the need for chemical pesticides, it does reduce the pressure for chemical treatment.

Pesticide chemicals have been developed and are being developed by industry which provide greater specificity, a greater margin of safety to the applicator and consumer, and with less effect on the nontarget areas of the environment. Pesticides will remain a tool in the overall pest management strategies, however, they will be used more judiciously and timely with less effect on our environment.

New pest management strategies are being designed and studied from an integrated approach invoking techniques utilizing proper managerial practices, breeding of crops, introduction of synthetic genes, pest reproductive interference, environmental modifications, growth regulators and improved pesticides and sophisticated application systems. The result will be reduced pesticide applications needed higher degree of pest specificity, and less pesticides introduced to the environment.

Both government and industry must regain the confidence of the public to insure that progress is made in implementing these new pest control strategies. This will require some straight shooting by both parties and a concerted effort to develop a technical team capable of implementing this system. The public needs to know that more is known about the newer pesticides and pest control strategies than was known in the DDT days, and that continued research and study is providing additional facts to strengthen and make these new pest control strategies more environmentall compatible. 
The purpose of our seminar, for the next two and a half days, is to bring you these concepts in pest management, the problems which still plague the pestides user and their possible solutions for your discussion and consideration. We invite questions from you as time permits, after each presentation and during the breaks. Thank you. 


\section{Introduction}

What is pest management? What makes it suddenly so important--even popular? How and when did it start? Why should I understand it? Is it compatible and usable in today's technical agriculture?

Pest management brings toge ther into a workable combination the best parts of all control methods that apply to a given situation. A somewhat more scientific definition of pest management would be: the practical manipulation of pest populations using sound ecological principles. The emphasis here is on "practical" and ecological." There are many ways of controlling insect pests, only a few of which are practical, and fewer yet ecologically sound, such that you do not create a worse situation. Pest management then, is "putting it all together"--using the best combination of control techniques to allow you to "live" with the pest while sustaining non-economic losses.

Pest management as a concept is not new. Only the name is. Many of the components of a sound pest management system were known some 50 years ago through the research of Isley in Arkansas. His extensive and foresighted work with cotton insects in the mid 1920's was sufficient to provide a sound bas is for today's pest management. His management of such pests as the boll weevil, the bollworm, and spider mites, was based on the principles of applied ecology, a vital segment of pest management.

Why is insect pest management needed? Why not continue to control insects as they have been in the past? The answers to these questions are somewhat complicated and yet they must be deal $t$ with and understood

Presented by Leon Moore, Extension Entomologist, University of Arizona, Tucson, Arizona 
Introduction of the organochlorine insecticide, DDT, began an era of insecticidal control of insects. Entomological research and extension work, largely emphasized the use of insecticides to control insects. One new insecticide followed another and new groups such as organophosphates and carbamates made their appearance. Insecticidal control provided a quick, inexpensive, and convenient method of controlling insects. It greatly slowed or stopped efforts such as Isely's to develop methods of insect control which were forerunners to the methods which we are using in our insect pest management systems today.

There were many reasons for the need to resume emphas is on the development of insect pest management. These were brought to light as problems began to occur resulting from large scale use of insecticides.

One of the first problems was the development of resistance or tolerance by certain insects to insecticides used against them. Beginning with the resistance of houseflies to DDT, this problem has continued to increase until today about 250 species have shown resistance to certain insecticides and some are resistant to one or more groups.

After a few years of widescale use of insecticides the problem of residues remaining in food and feed crops, in the soil, and in animals became known. Some insecticides such as the organochlorines, are highly persistent because of their chemical stability. 0thers such as the organophosphates are less persistent and rapidly degrade into harmless compounds. In order to cope with the residue problem, growers found it necessary to use the more toxic but non-persistent compounds. The shift from persistent to non-persistent insecticides has helped to relieve the problem caused by remaining residues but has been largely responsible for the occurrence of other problems. The non-persistent insecticides are generally more toxic, creating an additional heal th hazard to persons handling and applying them. They also are generally broad-spectrum in terms of destroying insects in the target 
area of treatment and require more frequent application to maintain insect control. This has resulted in a disturbance of pest-beneficial insect relationships, permitting pests of minor importance to rise to major pest status. It has also resulted in increased costs since the less persistent insecticides are generally higher priced and more applications are required. These factors have contributed to the need for developing pest management systems which emphasize alternate methods of control and minimize the use of insecticides.

\section{Basic Elements of Insect Pest Management}

Four elements basic to the development of a pest management program are sampling, economic levels, natural control, and insect biology and ecology. A good sampling system is extremely important in that it provides information on insect numbers in each field and must be developed to serve as a base for utilizing knowledge of natural control, economic levels, and biology and ecology of the major insects involved. Once the sampling program is established, these basic elements can be dovetailed together to serve as the foundation upon which practical components can be added to the total pest management program.

Before a pest management program can be initiated a great deal of basic information must be accumulated. This includes information about the agroecosystem, such as the crops grown, agronomic practices employed, soil type, irrigation water, and any other factor which relates to the production of the crops in the system. Detailed information must be available on the major pests and beneficial insects found in the agroecosystem in order to understand the seasonal occurrence and magnitude of all species of concern. The integration of all information on the agroecosystem itself with that on the biology and ecology of the pests and beneficial insects will provide significant insight on natural control in any particular area. The level of natural control provides the base on which all management practices are built, some of which enhance natural control. 
111. Practical Components of Insect Pest Management

When the basic elements have been established to form the foundation for the insect pest management system it is possible to build a solid and effective program on this base. There are several single-component control methods that can be incorporated into a multifaceted insect pest management system. These me thods have been, for the most part, used individually for control of specific insect pest problems. The combination of several of these into a comprehensive insect pest management program can provide better suppression of key pest species, and, at the same time, place less demand on any one method. The methods currently available and proved effective are: cultural control, biological control, chemical control, host-plant resistance, mechanical-physical control, and regulatory control.

The number of components that can be used in an insect pest management system is limited only by their practical availability. If the available components are to be used most effectively, emphasis must be placed on their use at the appropriate time. Some components are applied when the pest is a problem in the field while others are applied at times when the pest is overwintering or when it is at subeconomic levels. Generally, full utilization of all non-chemical methods should be emphasized on a year-round basis and insecticides should be utilized as a means of reducing populations that have reached or exceeded the economic level.

Several potential components are in various stages of development at the present time. These include peromone control, microbial control, chemosterilant control, and other control methods. These should become important parts of insect pest management systems as they are developed to the point of being practical for use.

W. Example of an Insect Pest Management Program - Cotton in Arizona

Emphasis in cotton pest control programs in Arizona has been aimed primarily at developing or adapting a cotton scouting program to the state which would serve as the basis for an insect pest management system. Two prerequisites to the effective 
practice of pest management are: (1) good field sampling, and (2) confidence in and use of sound economic levels of pest populations or damage.

In Arizona, scouting programs have been developed in two counties. The first was in Graham County which is now well established after six years of operation and the second in Pinal County which was started in 1971. The following is a brief discussion of the history, development and results of these programs.

\section{Graham County Program}

In 1968 the cotton growers of Graham County, through the ir pink bollworm committee, decided upon a cotton insect control program which called for scheduled weekly insecticide applications to the entire cotton acreage involved in the program. About 13,000 of the approximately 17,000 acres of cotton in the county were included in the program and were treated for six consecutive weeks beginning with the first week in August. The entire acreage was treated each week without regard to the insect populations present.

Some of the growers expressed dissatisfaction with the 1968 program because of cost and the appearance of certain secondary problems. Thus the pink bollworm committee asked the University of Arizona for assistance in improving the program for 1969. The University assisted the committee in organizing and conducting a scouting program whereby cotton insects could be controlled based on need.

Results of the 1969 program were that out of more than 600 fields, one required treatment for stink bugs, 18 for lygus bugs and about 65 for pink bollworm. Considering multiple applications on the fields treated for pink bollworm a total of 5,500 acre treatments were made. This compares to 13,263 acres treated six times or 70,578 acre treatments in 1968. Under continued scouting programs about 3,500 acre treatments were made in 1970 and approximately 14,000 acre treatments in 1971.

Cost per program acre was $\$ 15.00$ in 1968, $\$ 2.79$ in 1969, \$2.54 in 1970, and is estimated to be about $\$ 5.00$ in 1971 . 
From the standpoint of insect infestations, 1970 was lightest of the four years and 1971 was heaviest. Highest cotton yields were made in 1969 while yields in both 1970 and 1971 were down, primarily because of the weather conditions.

\section{Pinal County Program}

In Pinal County, a similar program was initiated in 1971 assisted by funds made available through a memorandum of agreement with the Plant Protection Division, U.S.D.A. Growers paid about one-half the program expenses initially but have now assumed full financial responsibility for the program.

The number and percentages of growers who followed IPM recommendations for the four project years are as follows: 1971 - 11 growers $(21 \%) ; 1972$ - 31 growers $(52 \%) ; 1973-57$ growers $(70 \%) ; 1974-44$ growers $(82 \%)$.

Actual numbers indicating either increases or decreases in private consultant fieldmen personnel are not available, however, it is believed that there have been no significant changes. Services provided by the two groups have been altered primarlly in the area of insect control recommendations. Chemical company fieldmen have shown a tendency toward use of economic levels through out the state since the beginning of the pest management effort in 1971.

New pest management methods and strategies introduced during the four years include strip or block cutting or alfalfa hay, lygus bug control in safflower to stop migration into squaring cotton, cessation of bloom-period spraying to control the pink bollworm, early crop termination to reduce numbers of diapausing pink bollworms, field treatment on an as-needed-basis and delayed first treatment to enhance beneficial insect numbers and forestall bollworm/budworm outbreaks.

The concept of IPM embraces all facets of the agroecosystem and therefore cannot be locked into a single crop in a multicrop system. The Arizona project has embraced small grains, grain sorghum, safflower, alfalfa hay and suger beets in its IPM effort. The grains are particularly vulnerable to excess treatment, 
sugar beets call for intensive insect monitoring during stand establishment and safflower and hay directly influence cotton insect numbers when these crops are in close association.

Interagency and interdisciplinary planning, cooperation, and program execution was carried out at the highest level of competency and interaction. The reciprocal flow of information and ideas as related to applied and basic research was both gratifying and rewarding.

Pest management personnel were continually up-dated and field-tested throughout the scouting period on a weekly basis. Their initial training was guided by a scouting handbook produced specifically for this program. The level of expertise attained by all personnel was very high. Grower response to IPM principles was, as the first paragraph indicates, at a satisfactory level when the program ended. Most noticeable was their acceptance of the fact that spraying cotton in the bloom stage to control the pink bollworm was futile and often led to secondary problems. The use of economic thresholds for all pest insects was accepted very well. Repetition, as is the case in most learning procedures, is the best tool in grower instruction and knowledge expansion. Grower contact is one of the keys to successful IPM.

\section{Grower Acceptance}

During the four year period of program operation, the number of growers increased to a maximum of 85 and the acreage to 31,508 in 1973. The decrease in growers and acreage that occurred in 1974 resulted from the threefold increase in per acre cost as the growers assumed full financial responsibility for the program. 


$\begin{array}{lcccc}\text { Year } & \text { Number of Growers } & \text { Acreage } & \begin{array}{c}\text { Grower Cost } \\ \text { Per Acre }\end{array} \\ 1971 & 51 & 15,322 & 0.75 \\ 1972 & 60 & 18,437 & 0.75 \\ 1973 & 85 & 31,508 & 1.00 \\ 1974 & 54 & 21,458 & 3.00\end{array}$

Total grower contributions for the four years was approximately $\$ 121,201.25$. In 1971, a five member grower committee was formed and it was through these growers that the Extension Service cooperated in initiating the Pinal County Pest Management Program. Two growers were added to the committee in 1972 to broaden the membership base for different county areas. The committeemen were more active in program planning and development and began considering incorporation. The formation of a non-profit corporation occurred in 1973 with committee members becoming the governing board. A slate of officers was elected and growers became corporation members as they contracted to participate in the Pest Management Program.

In addition to begin directly involved in implementation of the 1973 scouting season, the board requested that the corporation be involved with crops in addition to cotton. The Growers Pest Management Corporation handles all aspects of the Program in 1974. The Cooperative Extension Service cooperated with the corporation in providing training for the ir personnel and serving in a field supervisory capacity.

\section{Benefits}

Reduced operational charges were first realized in 1974. The reduction was due primarily to personnel assignments in relation to number of fields scouted. Work load efficiency was the key to operational cost. Additionally fields assigned to each team were chosen to produce a cohesive unit, the reby reducing travel $\cos t$.

Records of net profits due to IPM are not available from individual growers. There was, however, a trend toward reduced production inputs and improved pest control (Table 1). Growers are becoming more conscious of management factors related to IPM. Water management, fertilizer requirements, weed control, good ground 
preparation, etc., are all part of managing a crop to a successful conclusion.

The results of the soil samples taken during the three years of pest management show no significant increase in pesticide residues in the soil. There has been a reduction in the total pesticide usage in Pinal County with a resulting increase in beneficial organisms.

Obviously, a reduction in numbers of pesticides applications and recommending chemicals at correct dosage levels when treatment is necessary will delay occurrences of pest-resistance.

New avenues of communication were opened and old avenues restructured and strengthened between growers, the Extension Service, and the University. The activity of USDA-APHIS was well received and many valuable contacts made. The individual handling the monitoring phase had high rapport with growers in and out of the program, involved University personnel, pertinent state, county, and local governmental agencies, and local business that provided needed services. A good scouting program is the foundation on which the building of integrated control or pest management can be constructed. The stories of this building may include better use of beneficial insects, improved cultural practices, proper use of insecticides, strip-cutting or strip-planting of alfalfa for lygus bug control, etc. There is no limit to the size of the integrated control system and new methods can be easily made a part of the system as they are developed to the point of being practical. It should be emphasized, however, that the development of integrated systems is strongly dependent on sampling or scouting programs that provide the information necessary to make good management decisions. 
Table 1 - Pesticide costs for Pinal County Pest Management Growers for 1971 , 1972, 1973, and 1974.

\begin{tabular}{|c|c|c|c|c|}
\hline Factors & 1971 & 1972 & 1973 & 1974 \\
\hline Growers & 51 & 60 & 85 & 54 \\
\hline Fields & 387 & 480 & 722 & 503 \\
\hline Acres & 15,260 & 19,313 & 31,582 & 21,458 \\
\hline Fields Not Treated & -- & 12 & 29 & 16 \\
\hline Acres Not Treated & -- & 95 & 982 & 687 \\
\hline Acres Treated & $6,390 \mathrm{I}$ & 18,11521 & 29,99531 & 20,4314 \\
\hline Total Acre Treatments & 56,232 & 173,330 & 156,563 & 106,252 \\
\hline Range of Treatments & $1-13$ & $0-16$ & $0-12$ & $0-10$ \\
\hline $\begin{array}{l}\text { Total Cost of All Acre Treat- } \\
\text { ment }\end{array}$ & $\$ 196,812$ & $\$ 606,655$ & $\$ 626,252$ & $\$ 531,260$ \\
\hline $\begin{array}{l}\text { Average Total Cost per Acre } \\
\text { Treated } 5 /\end{array}$ & $\$ 30.80$ & $\$ 33.49$ & $\$ 20.88$ & $\$ 26.00$ \\
\hline
\end{tabular}

1/ Data not available for 33 growers with 228 fields totaling 8,870 acres.

2/ Date not available for 7 growers with 38 fields totaling 1,103 acres.

3/ Data not available for 4 growers with 14 fields totaling 605 acres.

4/ Data not available for 3 growers with 8 fields totaling 340 acres.

5/ Cost calculated @\$3.50/a./Treatment - 1971 and 1972, @\$4.00/a./Treatment - 1973

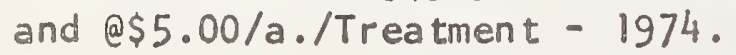


Q: Leon, you mentioned your group of growers incorporated. What is the advantage of their incorporating. You also mentioned a contract, a contract with whom and does the contractor assume any liability if IPM does not work in the state of Arizona?

A: Probably all of those are tied together. One of the things is liability. If they are incorporated, it sort of takes away from, let's say, the board or from the committee that is running the show. In other words, liability is spread around more if they have a corporation, and so they have done this from the standpoint of obtaining insurance and all the other things that might be involved from a liability standpoint. They just think that incorporating is the way to do this. Now the signing of the contract is also part of it and as a man signs a contract, he then becomes a part of the corporation and, of course, he is suing himself to some extent, if he goes in and sues. We have really had no problem from the standpoint of liability, but it is just a move that we think is necessary to avoid any unpleasant thing that might come along in terms of a president or somebody being called.

Q: Who are the contracting parties, the University of Arizona and the growers?

A: No, absolutely not, no the University is not involved, we are only in an advisory role. The grower, pest management corporation and the grower are the contracting parties.

Q: What is the psychology that you use to get your growers together to practice integrated control?

A: We started with a sort of corp of people who are the progressive type. They like to look into this sort of thing and we showed that by working with them that you can use economic levels, for example, and not endanger this high amount of money per acre. Now we're not talking about cotton like what you are talking about, tree fruits and the same thing is true for lettuce, for example, and those are much tougher to crack than another situation, but I think that you simply got to demonstrate to them, maybe on a small scale basis first, that economic levels are valid, you got to get their confidence and then from this you can begin to branch out, until you gain the confidence of the people, you might as well not try to do too much. That's the thing that we try to work on and we try to do it through the growers by having a grower committee out front and center because the other growers will then follow that committee where they wouldn't if 1 , as an extension entomologist, went out there they would say, well that is his business to do this sort of thing.

Q: Have you tried this with any other group?

A: Yes, we are just beginning to get into lettuce, we do not have an actual program in lettuce. Most of our applications in practice are now scheduled for lettuce insect control. But we have had some demonstration work going for the last two years now, which we have been able to exactly cut in half the use of insecticides and produce the same quality and quantity of marketable heads of lettuce and what we got to do then is show the grower and gain enough confidence out of them that we can do this. Now the problems that you run into, doing something like this, are they have been doing something like this for a number of years and are scared to death of the market situation and all the other things making it tougher to get to. But we know by doing this demonstration work and research work that we have and doing it over enough years that eventually we are going to be able to proceed in those 
areas that we definitely need it.

Q: You mentioned four approaches, four separate approaches, acreage wise, what percentage of the total state is it?

A: We now have 300,000 acres and four programs that cover probably around 40,000 acres. So we are still relatively small in terms of percentage of total. Now, of course, a lot of our growers have different methods of sampling, they do their own or hire someone specifically to do this and I am not including these in this program because they are private consultants that are working chemical company field men and I have a lot of people out sampling and so there are various ways of having coverage, but there were simply not enough of these to do the job and do it right.

Q: The Pink Bowl Worm pheramone traps, was there any other economic benefit other than concentration of natural enemies or were they pretty much the same if they used chemicals?

A: We have just gone into that in a big way this year, and as 1 say, the whole Safford Valley we have treated with traps and doing it from an early season standpoint only, in which you know we are not interested in the late season in which we get most of the damage. We are trying to reduce it and trying to step back say one generation, the economic level. I think maybe we have done that. Now if we suppress the population enough to set them back a generation, then you see what you are doing with maybe as much as four or five treatments setting the population back. We do know that we have had to treat almost no cotton in that valley till the time I left, last week, 500 acres was the amount of treatment or a little less. So it would appear to be doing some good, but we want to be conservative on that and try it under different circumstances, maybe it was a light year in the area. We know that the Pink Bowl Worm is not as severe this year as it has been in some other years in all areas, but it's still in the other areas we are having to treat.

Q: You mentioned in the control of lygus bug that you sprayed safflower. Was that, the safflower, grown by these growers too, or was that on an adjacent farm?

A: Good question, it is a little bit of a problem when it's an adjacent farm and the guy is a safflower and hay producer and not a cotton grower. In cases, the cotton growers have been willing to pay for this, for the neighbor. In other cases, they are just good neighbors so they will treat. We have not been able to show an economic benefit to the safflower grower, and that's one of those things where you have to hope for community action and we have received good cooperation. Better than I would of thought we could, but again growers are essentially good people and they like to think they are good neighbors. They usually participate in this type of thing, if they know it is doing some good. If they are, let's say, a hay producer, one of the reasons why we had to get into this kind of thing was because of the residue problems we were having in our hay and dairy a few years ago, so they are pleased to hold down the number of insecticide applications as much as we can.

Q: Have you used the sterile male technique for the Pink Bowl Worm at all?

A: No, that's only in the San Joaquin Valley. We produce them in Phoenix and ship them to the San Joaquin Valley and they've been doing that by the millions. We have not been able to produce enough of the sterilized males to use them in any other area except the San Joaquin. So we don't really know because of the circumstances there, just exactly how much good these are doing. You see, the San 
Joaquin has never been infested by the Pink Bowl Worm and it's just that they find a few there every year, and we said that this is the logical place to use this to keep tinem out and so they go in and dump millions of these things every year. They have not yet developed a Pink Bowl Uorm problem in the San Joaquin, but would they have developed one if they weren't dropping these, that's the $\$ 64,000$ question. I'd like to see it incorporated now on top of our pheramone progran in Graham County, Arizona, because we know what the situation is over a number of years and 1 think we could get a better yard stick of what is going on, maybe we will be able to do that eventually.

2: Was the problem noticeably improved, or was it a real problem in those four areas?

A: Yes, it is definitely quite a problem in all those areas and we still have a lot of improving to do, because even in the Pinal Co. program, it shows that we are down to an average of about five to six applications on the average, that is still a lot of applications and when you are doing this over an areawide basis, there is just about no way that you are going to have the ability to make it any less, but over in Graham County where we've been able to pull this thing to such a low level, it's of great help to the industry. I had one bee keeper come to me last year and said the pest management program made me $\$ 20,000$ this year. It makes you feel good to hear results as a spinoff of the the program and it is a very heal thy industry and it's helping the cotton growers a heck of a lot to have those honey bees because they do help the long stapile cotton, there's no question about it. Graham County is almost entirely long stapile from the standpoint of pollination.

Q: What is the current beginning salary of a beginning scout and what would you make after you were trained for one year?

A: Okay, we have adjustment levels, $\$ 100$ beginning and $\$ 110$ with a year of experience, per week. We have different levels of pay, of course, there are certain factors there at a higher level. We've found that our scouts will average about 22, 23, or 24 years of age. They are college age mostly, we have both male and female involved and actually, I have to admit that some of our best scouts have been girls. They seem out to prove that they can really do the job, but they have really done a good job for us and we also use a lot of school teachers. 

Nosema locustae: AN ALTERNATIVE METHOD OF GRASSHOPPER CONTROL

\section{Introduction}

Grasshoppers are the most important insect pests on rangeland in the western United States. Economic infestations are usually controlled by aerial application of insecticides. The use of chemical insecticides against grasshoppers, as well as other insects, has been criticized because of possible harm to the environment. This concern has provided support for developing al ternative methods of insect control, of which this work with Nosema locustae as a microbial control agent against grasshoppers is but one example.

Microbial control can be defined as the method of using pathogenic microorganisms for control of noxious pests. Grasshoppers, like most insects, are associated with numerous microorganisms, some of which are pathogenic. Known pathogenic microorganisms in grasshoppers include bacteria, fungi, viruses and protozoa, but the viruses and protozoa have received greatest attention because most bacteria and fungi are rather restricted to specific temperature and moisture regimens for growth and dissemination. A number of protozoa and viruses that have been isolated appear potentially useful in applied microbial control; however, because of financial and physical limitations, it has not been possible to develop all of them simultaneously. To select one of them for concentrated effort, criteria based on the needs and objectives in control of grasshoppers were devised for comparing these pathogens. In this paper, 1 will present the criteria we used to select Nosema locustae for major emphasis.

$$
\text { Grasshoppers, Environment, and Pathogens }
$$

Steinhaus (1954), considered the interdependence of the insect, environment,

Presented by John E. Henry, USDA, Agricultural Research Service, Rangeland Insect Laboratory, Montana State University, Bozeman, Montana 
and pathogens as the determinant of natural epizootics. I feel this same interdependence exists in the applied use of the microbials, particularly in programs directed at long-term control. Therefore, in order to develop a successful system, decisions and designs of experiments should be based on knowledge of the factors in this triad.

\section{Grasshoppers:}

There are about 200 species of grasshoppers in western United States, most of which belong to one of three main subfamilies. Only about $15-20$ species are of economic importance because they are frequent or abundant in outbreaks and/or they compete with man or his domestic animals for preferred forage and crops. The remaining species either do not occur at high densities, do not compete for important plants, or both. A few species may be beneficial because they feed primarily on undesirable plants.

Virtually all species of grasshoppers exhibit ranges in food plant preferences and utilization (Mulkern et al. 1969). The food plant preferences for some species are very broad, including broadleaf plants, grasses, sedges, plant debris, and animal tissue including other grasshoppers. At the opposite extreme some species are very restricted in host plant selection and feed only on several closely related species of plants. These species considered as economically important vary from being highly omn iverous to highly selective in food preferences.

\section{Environment:}

Al though grasshoppers inhabit most areas of the world, our main concerns are with those that inhabit semiarid rangelands. Grasshoppers, as well as their natural enemies such as other insects, microorganisms, insectivorous vertebrates, etc., are well established in these areas. The interactions among grasshoppers, their natural enemies, and the variable climatic conditions 
that characterize semiarid rangelands can cause marked fluctuation in population densities from one year to the next and from one area to the next. Generally, however, the densities of grasshoppers are cyclic and usually reach maximum levels every seven to fifteen years.

Grasshoppers compete with grazing animals for available forage and, when this is in short supply, are capable of migrating to nearby crops and pastures. Grasshopper densities of more than eight per yard square generally are considered to be economically important. However, the need for control also depends on the quantity of available forage and the financial capabilities of landowners. Control programs seldom have been conducted in areas where densities averaged iess than 15 per $y^{2}{ }^{2}$. Cooperative control programs covering from 5,000 to more than a million acres in solid blocks are conducted on cost-sharing arrangements between the Federal government, state government, and private landowners.

\section{Pathogens}

All microorganisms that are considered potentially useful for grasshopper control are natural pathogens. The viruses include two that have been characterized as to structure and pathogenicity, two that have been partly characterized and several that are known to occur but have not been investigated. The protozoa include an amoebic-type organ ism and a number of Sporozoa. Among the Sporozoa are three Microsporida with in the genus Nosema. Each of these pathogens exhibit characteristics that might be useful in an applied program. The characteristics considered most important in microbial control of grasshoppers are (a) suitable virulence, (b) suitable host range, (c) potential for mass production and prolonged storage, (d) adaptability to efficient low-cost application techniques, (e) suitable viability in the habitat of the host following application, and (f) potential for registration as a microbial insecticide.

\section{a. Suitable Virulence:}

Because low densities of grasshoppers can be tolerated, the objective has been to select an agent sufficiently virulent to cause some short-term control, 
but at the same time sufficiently non-virulent to persist in the host population for a number of years and thereby reduce the extent and frequencies of outbreaks. An ideal approach to the management of grasshoppers would be to apply a microbial agent during the early stages in the density cycle and prevent any additional increase. However, this approach may not be realistic because reproductive and survival potentials among grasshoppers are at the highest levels and losses to natural enemies are at the lowest levels during the early phases in the density cycles. Conceivably, applications of a microbial that caused 70 percent reduction in densities at this time might not be as effective as a 20 percent reduction when pressure from natural enemies is more intense. Also, even if this approach was effective, implementation might not be possible because landowners and operators usually are reluctant to enter into control programs prior to the existence of threatening or damaging population densities. Most land managers are familiar with the potential variability in rangeland conditions and of the severe fluctuations that often occur in the densities of grasshoppers. Therefore, from a practical standpoint grasshopper control programs, including microbial applications, will not be initiated until densities exceed the economic thresholds. For this reason some short-term reduction is required to satisfy the immediate needs of the land operator and persistence is required to maintain the densities at sub-economic levels.

b. Host Range:

Usually 30 to 50 species of grasshoppers occur in an outbreak area. Of these about five or fewer species usually predominate and of ten are the only economically important ones. For this reason, a pathogen must be able to infect or reduce the densities of the predominant species. Also, because the predominant species usually include one or more species of each of the 
three main subfamilies, the pathogen must be effective against virtually all grasshoppers. It is equally important that the host range be limited to grasshoppers, not only for safety in applied use, but also so as not to diminish the effectiveness of existing natural enemies.

c. Mass Production and Prolonged Storage:

Outbreaks or potential outbreaks usually occur over extensive land areas, often exceeding one million acres. In order to be effective, the microbial agent must be applied over the entire area. Therefore, large quantities of the pathogen must be available to treat such areas. From the standpoint of efficient use of facilities and personnel, production should continue throughout the year and spores should be stockpiled. This then requires that the pathogen be capable of withstanding prolonged storage without serious loss in viability.

d. Adaptability to Efficient Low-Cost Application Techniques:

Unl ike intense agricultural areas where per acre gross returns are hundreds of dollars per year, the average gross returns on rangeland is less than $\$ 5.00$ per year. For this reason land operators generally are reluctant to control grasshoppers on their entire holdings, even when done so under a cost-sharing arrangement with the state and Federal governments. Efficiency is increased and per acre costs are reduced when larger areas are treated that permit long swath runs (20 to 50 miles) and wide swath widths (500 to $2000 \mathrm{ft.}$ ) using Category A aircraft such as the Douglas DC-3, Lockheed $\mathrm{PV}-1$, etc. Also, the pathogen must be in highly concentrated preparations that permit operationally efficient payloads.

e. Suitable Viability:

The diurnal temperatures of range lands habitats may vary between 7 to $38^{\circ} \mathrm{C}$ during the time of year when grasshopper control programs are conducted. Ground temperatures might reach $50^{\circ} \mathrm{C}$. Cloud cover usually is minimal, al though evening thunderstorms are frequent. A pathogen might, therefore, be subjected to a variety of adverse climatic conditions and to intense solar radiations which it must tolerate 
without serious loss in viability. Materials and techniques are available that could be applied to the pathogen to aid in preserving viability under such adverse conditions, but such materials and techniques add to the cost of the applications. Such materials might increase infectivity and viability to the point that the added costs are offset so these procedures certainly should be studied. However, such studies often can be justified only after a definite control potential has been demonstrated.

f. Potential Registration:

Just as chemical insecticides are registered for use, microbial agents also will be registered for applied uses. In this country authority for registration rests with the Environmental Protection Agency (EPA). EPA will establish the standards for safety, efficacy, allowable residues, etc., for all microbial agents. A pathogen then must exhibit characteristics that indicate probable success in satisfying the requirements for registration.

\section{Nosema locus tae}

Canning (1953) described Nosema locustae from a laboratory culture of the migratory locust, Locusta migratoria migratorioides, in England. Prior to that Steinhaus (1951) reported infections by an undescribed Nosema in grasshoppers sent to him by workers previously associated with our laboratory at Bozeman, Montana, and subsequent research established that this was Nosema locustae. In 1961, I initiated studies of pathogens of grasshoppers that subsequently led to the selection of Nosema locustae for our most determined effort at applied development. This decision was based on an evaluation of Nosema locustae and other known pathogens on the bas is of the characteristics listed in the previous section.

a. Virulence:

Nosema locustae infects the fat tissue of grasshoppers and in so doing deprives them of their energy supplies. It is one of the least virulent pathogens 
of grasshoppers. Canning (1962 a, b) observed variation in the infectivity of different species of grasshoppers and reported difficulty in infecting adults. However, she observed increased mortality following inoculation of third instar nymphs of Locusta migratoria migratorioides. We have established that the $L_{50}$ at 25 days postinoculation of third instar nymphs of Melanoplus sanguinipes or M. bivittatus, which are economically important grasshoppers, is $5.5 \times 10^{5}$ spores. Of the known specific grasshopper pathogens, including fungi, viruses, and other protozoa, only the amoebic protozoan and gregarines are less virulent (Henry, 1970). Recently we (Henry \& Oma, 1947 b) showed that Nosema locustae was much less virulent in grasshoppers than the two other microsporidans, Nosema acridophagous and Nosema cuneatum. The same study showed that virulence of Nosema locustae was enhanced when the grasshoppers were subjected to added stresses such as crowding. Field tests have established that one billion spores per acre will cause about 50 percent reduction in the densities of grasshoppers within four weeks following application (Henry 1971, Henry et al. 1973, Henry and Oma, 1974 a).

b. Host Range of Nosema locustae:

Following her initial description of Nosema locustae, Canning (1962a) extended the host range to include the African locust, Schistocerca gregaria, and five species of grasshoppers from North American, including the economically important Melanoplus sanguinipes, Melanoplus bivittatus and Camnula pellucida. More recently I (Henry, 1969) reported that 58 species of grasshoppers, a species of cricket, and a pygmy locust were susceptible to infection. This list included species that belonged to the three main traditional subfamilies of grasshoppers and included all economically important species. Recent studies have extended the host range to include additional species of grasshoppers and the Mormon cricket, Anabrus simplex. Laboratory studies have established that the eastern house cricket, Acheta domesticus, was not susceptible to infection. It appears that the host range includes most, if not all, species of grasshoppers, some species of crickets and other close relatives. 


\section{c. Mass Production and Prolonged Storage of Nosema locustae:}

Canning (1962b) felt that the inability to mass produce spores outside the grasshoppers prohibited development of Nosema locustae for applied use. However, we have produced sufficient quantities of spores for all of our field tests, including a 46,000-acre pilot test, through laboratory cultures using the grasshopper Melanoplus bivittatus. This species is relatively large and can tolerate extremely high spore concentrations. As reported previously, (Henry, 1971) each grasshopper produces in excess of one billion spores, and in more recent studies the average production was increased to more than two billion spores (or more than two acres of treatment) per grasshopper. Occasional concentrations of $2.0 \times 10^{10}$ spores have been harvested from heavily infected females and average productions of $8.0 \times 10^{9}$ spores per grasshopper appear possible. Therefore, mass production of spores in grasshoppers does indeed appear economically and physically possible.

Some difficulty has been experienced in storing spores. Henry and Oma (1974a) showed that viability was reduced drastically after storage in water at - $100 \mathrm{C}$ for one to three years or in cadavers at $-100 \mathrm{C}$ for one year. For this reason, the spores used in field tests have been produced within four months of application. However, preliminary studies on storage in liquid nitrogen have indicated that acceptable prolonged storage procedures can be devised.

d. Adaptability of Nosema locustae to Low-Cost Application Techniques:

As with most microbial agents, the infective stage of Nosema locustae, the spore, must be ingested by the grasshopper. For most field tests we have applied spores to wheat bran, which is then spread by aerial or ground equipment. The standard application rate (Henry et al. 1973) has been one billion spores on 1.5 lb wheat bran per acre. If it is applied with the predominant grasshoppers (usually Melanoplus sanquinipes) are mostly third instar nymphs, this treatment kills about 50 percent of the grasshoppers within four weeks and causes sufficient infection ( 30 to 50 percent) 
among survivors that reproduction is reduced or inhibited. In most instances, the initial reductions in densities will be sufficient to change the status of the infestation from economic to noneconomic.

There are some important disadvantages to using a bulky carrier like wheat bran for distributing Nosema locustae, particularly in comparison to application in ultralow-volume sprays. These include purchase price, treatment costs, handling expenses, and reduced payloads for airplanes. However, these disadvantages are more than offset by advantages in the use of wheat bran. For example, recent field studies have established for chemical insecticide applications are possible with wheat bran which then reduces the per-load application time. Also, we have established that complete coverage is not required in the application of Nosema locustae on wheat bran as is required for suitable control with insecticides. Therefore, retreatment of areas that were inadvertently missed is not necessary. Chemical insecticide applications are restricted to early morning hours when the temperatures are low and thermal currents are not produced. Thermals are updrafts of warm air rising from the ground that cause loss of spray droplets through drying or increased drift. Thermals usually restrict aerial insecticide applications to one load per suitable day in western United States. In contrast, we have achieved excellent results in applying wheat bran with spores throughout the day when temperatures and winds would prohibit spray applications. This al lows for more efficient use of airplanes and crews, which lowers the cost of applications. Also, our studies have shown that ULV sprays with water require about ten times more spores than wheat bran applications to achieve comparable results. The increased production cost of spores for ULV sprays greatly exceeds the costs involved in using wheat bran. e. Viability of Nosema locustae in field applications:

We have completed few studies on the effects of adverse climatic conditions on spores of Nosema locustae. Preliminary studies have shown that viability is decreased by temperatures over $40^{\circ} \mathrm{C}$ and by exposure to solar radiation for two or more hours. 
Nevertheless, the field studies have established that sufficient viability is ma intained that the densities of grasshoppers are reduced and infections occur among survivors. We believe that the wheat bran provides some protection for the spores and we have observed that most of the bran is consumed by grasshoppers within two hours of application. If future results continue to justify studies on Nosema locustae, the development of techniques that maintain high spore viability would help increase efficiency and thereby reduce the cost of this pathogen.

Nosema locustae persists in the field at least one year following experimental application (that is the limit of our testing) and it pers ists for a number of years in antural enzootic areas (Henry, 1972). We have found spores in the froth of egg pods and have observed that some nymphs from egg pods laid by infected females were infected. We suspect that young nymphs consume relatively large amounts of organic debris, including the cadavers of grasshoppers from the previous season, some of which possible contain spores of Nosema locustae. Apparently these are the principle means by which grasshoppers become infected by spores produced during the previous generation.

\section{f. Potential for Registration of Nosema locustae for General Use:}

At present no protozoan has been registered for general use against insect pests and, therefore, the criteria for registration and labeling have not been established. Certainly such criteria will include safety to non-target organisms, particularly warm-blooded animals, high efficacy, and development of sound bioas say techniques. Tests conducted to date indicated that Nosema locustae will not infect warm-blooded animals and that efficacy based on degree of infection is workable. Also, bioassays based on infectivity are sufficiently sensitive to detect changes in the infectivity of this pathogen. At this point the propect of registration of Nosema locustae against grasshoppers in encouraging.

\section{Prospects of Success}

As mentioned previously, all potential agents exhibit characteristics that might be useful in microbial control of grasshoppers. This raises the question of whether 
the selection of Nosema locustae achieved our purpose of placing the maximum effort on developing the pathogen with the greatest potential for success. Our studies continue to show that Nosema locustae can be effective as an al ternative method of controlling grasshoppers. We can reduce high densities of grasshoppers to tolerable levels within one month by disseminating spores of this pathogen. We can reduce reproduction of grasshoppers which should reduce densities over a longer period. Yet, questions remain as to whether Nosema locustae will reduce the extent and frequencies of outbreaks, and whether the land operators will utilize this method for control of grasshoppers.

In 1975 we initiated a large-scale pilot test from which we hope to derive answers to thellong-term control potential of Nosema locustae. The initial results from the seasons of application indicate that continued development of Nosema locustae is $j$ ustified. However, this test will not be completed for at least three years so any further assessment of potential success would be premature.

1 feel it is extremely difficult to predict the public response to Nosema locustae as a method of grasshopper control. Many land operators have expressed the need for controls of this nature because they are concerned about the nonselective action of the chemicals presently used against grasshoppers and about the cost of these treatments.

Certainly the cost of Nosema locustae must be sufficiently low to compensate for the slow reduction in densities. My personal view is that Nosema locustae could be used most effectively by a group of cooperating landowners, possibly in conjunction with governmental agencies, as the first line of defense against grasshoppers in an integrated program where chemical insecticides are used sparingly to reduce densities in restricted "hot spot" areas. If it were used in this way, I am confident that the use of Nosema locustae will be accepted by the people involved and that grasshopper control will be realized. 
Canning, E. U. 1953. A new microsporidian, Nosema locustae n. sp., from the fat body of the African migratory locust, Locusta migratoria migratorioides (REF). Parasitology $43,287-290$.

Canning, E. U. 1962a. The life cycle of Nosema locustae Canning in Locusta migratoria migratorioides (Reiche and Fairmaire), and its infectivity to other hosts. J. Insect Pathol. 4, 237-247.

Canning, E. U. 1962b. The pathogenicity of Nosema locustae Canning, J. Insect Pathol. 4, 248-256.

Henry, J.E. 1969. Extension of the host range of Nosema locustae in Orthoptera: Ann. Ent. Soc. Am. $62,452-53$.

Henry, J.E. 1970. Potential microbial control of grasshoppers and locusts. Proc. Int. Study Conf. Current and Future Problems of Acridology. pp. 465-468. Henry, J.E. 1971. Experimental application of Nosema locustae for control of grasshoppers. J. Invertebr. Pathol. 18, 389-394.

Henry, J.E. 1972. Epizootiology of infections by Nosema locustae Canning (Microsporida: Nosematidae) in grasshoppers. Acrida 1, 111-120.

Henry, J.E. and Oma, E. A. 1974a. Effect of prolonged storage of spores on field applications of Nosema locustae (Microsporida: Nosematidae) against grasshoppers. J. Invertebr. Pathol. 23, 371-377.

Henry, J.E. and Oma, E. A. 1974b. Effects of infections by Nosema locustae Canning, Nosema acridophagus Henry, and Nosema cuneatum Henry (Microsporida: Nosematidae) in Melanoplus bivittatus (Say) (Orthoptera: Acrididae). Acrida 3, 223-231. Henry, J.E., Tiahrt, K., and Oma, E. A. 1973. Importance of timing, spore concentrations, and spore carrier levels in application of Nosema locustae (Microsporida: Nosematidae) for control of grasshoppers, J. Invertebr. Pathol . 21, 263-272. Mulkern, G. B., Pruess, K. P., Hagen, A. F., Cambe 11, J. B., Knutson, H., and Lambley, J. J. D. 1969. Food habits and preferences of grassland grasshoppers of the north central Great Plains. N. Dak. State Univ. Agr. Sta. Bull. 481, 1- 32 
Steinhaus, E. A. 1951. Report on diagnosis of diseased insects 1944-1950. Hilgardia $20,629-678$

Steinhaus, E. A. 1954. The effects of disease on insect populations. Hilgardia 9 , $197-261$ 


\section{- John Henry, Ph.D. -}

Q: When you sprayed during the entire day, was there a difference in terms of if you sprayed in the morning. Would they feed during the day or would they feed at night or do they feed all the time?

A: We did find a difference. We probábly did lose some feeding activity, simply because when it gets that hot, the grasshoppers get up on to the vegetation, they are not feeding on the ground. In the morning, they will feed on the ground. There is a time factor that we are going to have to look into, but we do know that we can still infect them even at this time of day.

Q: Because the material is being kept viable?

A: I don't know if the material is being kept viable or if they actually are getting down to get it. We don't have the data analyzed at this point, so that we can say that there was a difference between the time of day at this point. Generally speaking, I would say yes.

Q: You say after the treatment, about 50 percent of the population are dead in four weeks and the remaining 50 percent will not live to reproduce?

A: No, of the remaining 50 percent, about 30 to 50 percent of those are infected such that their reproduction is eliminated or is drastically reduced. In other words, we are cutting the reproduction. They will continue to die naturally, but at four weeks that is what we see.

Q: Wouldn't it be more economically feasible to gather wild grasshoppers rather than rearing them?

A: We have considered that and 1 don't think it would be efficient because of the bulk of material that we would have to run through in separation and clean up. In working with production in the laboratory or rearing facilities, such as we have, we can collect on ly real heavily infected grasshoppers and from that our spore nutrition is already pretty clean.

Q: You mentioned Nosema locustae testing on several species of grasshoppers and also on field crickets and mormon crickets, has it been tested, at this time on roaches?

A: Yes, we have tried roaches at Montana State eight or $n i n e$ years ago and as 1 recall, well I know we didn't get anything out of it. I can't recall the particulars of the test, but I can say that roaches are not effected, but I don't have the solid data to back it up.

Q: Have you been constructing a public relations program to go along with this or what kind of public relations have you initiated, if any at all?

A: The only public relations that we have initiated is dealing with the ranchers in our area. Generally, I think ranchers are ready for some thing like this, ranchers are definitely for the approach to grasshopper control. Most of the insecticide programs in the western United States in the past year, have been conducted on federally administered lands. BLM lands, Forest Service lands, Indian Service lands, primarily because it is difficult to get ranchers as a group, together in a control program. APHIS will not touch any program less than 5,000 acres maybe 10,000 acres, but they want large blocks in order to be effective, they have to have large blocks in order to do a reasonable job with Malathion, in other words, they have to treat large areas. It is becoming increasingly difficult to sign up all ranchers in such an area for 
various reasons. First of all, Malathion is not always effective. Secondly, the cost is getting quite high. This past year the cost has increased by a third. Now, it isn't very much really, the contract cost on a government program is about $\$ 1$ per acre, which, in most states, Montana included, it is equally shared by federal government, state government and private individuals, so it only costs the private individual about $\$ .30 /$ acre. When you are figuring the actual value or his overturn on that per acre is less than $\$ 5$, which is a considerable amount. They are becoming increasingly hesitant about going into this type of program. We also know that Malathion does suspend in cotton and in other areas and does put us into a bind as far as requiring future spray programs. Where we have sprayed in the past, we shall spray again, we can predict that, whether it is because grasshoppers are there or because we have sprayed there before, I cannot say, but this has happened before. So ranchers are looking for al ternative methods or leaving grasshoppers, but they are very much interested in something like Nosema locus tae, even though it does not get as dramatic results as the insecticides.

Q: To what degree is the Nosema self-perpetuating?

A: They will stay in the population, we know, for one year.

Q: Will they reproduce more once within a population?

A: Yes, definitely. The spore production goes up dramatically after we have applied the material. It will stay in the population at least one year, now this is the limit of our testing because I will not go out on small plots and consider this reliable. This is certainly one of the reasons why we are on this large scale pilot test to be able to check this over a period of years. We are shooting for three years, we hope that this gets longer. 

Pesticides contribute enormously to the quantity and quality of food, feed fiber, wild ife habitat and environmental quality. Our farmer now produces food for himself and over 50 others; we have the highest standard of living in the world and can help feed nations abroad by exporting not only our produce, but our technology. Part of this technology is the effective and safe use of the various pesticides needed in a wide variety of situations.

All pesticides marketed in the United States are subject to very extensive and detailed testing for efficacy in the intended use, toxicity of different types and potential impact on the environment. This process will take from five to ten years from discovery of activity to marketing for one crop use, and cost from ten to fifteen million dollars. Regulation of pesticide use by federal and state agencies is very extensive and continues to increase the cost. Some of this regulation seems warranted, however, to ensure proper care in application of these materials and prevent undesirable consequences from the ir misuse.

The labels and other literature by pesticide marketers and several state and federal agencies provide information on the characteristics of these chemicals and instructions for their use. Proper application of these products to achieve the desired results without injury to property else where or the environment is important. Serious losses can be sustained because of crop or animal damage, illegal residues in produce or water, air or soil contamination. These problems can develop because of improper application of sprays or from vaporization of compounds afterward. Since 1 am familiar with herbicides and they provide a variety of characteristics to illustrate the problems and procedures of confining pesticides

Presented by L. E. Warren, Ag-Organics Department, Research and Development, Dow Chemical U. S. A., Davis, California 
to their target areas, my presentation will involve the volatility and drift of herbicides.

Many different herbicides are applied by air or ground equipment to control weeds and wood plants in fields, forests, roadsides and right of ways. Some application methods can result in movement of small particles to offtarget areas as the spray falls. Depending on the nature of the herbicide and the amount that moves off the target area, the effect may be manifested in injury to plants or animals or possible illegal residues in plants, animals or water. In addition, loss of intended activity on the target area may result in inadequate control or require a greater quantity of herbicide to compensate for the loss.

The movement of herbicides in the air to off-target sites can result also from vapors that may form after application of certain herbicide formulations. We should distinguish between the two sources (spray drift and vaporization) and eliminate or reduce the extent of both to acceptable minimums.

We define spray DRIFT as that part of the spray that moves off the target in fine particles formed as the spray leaves the nozzle at the time of application, and falls out on adjacent property. VAPORIZATION is the escape of molecules of the herbicide by volatilization from the falling or fallen drops before or after reaching the target area. The volatilities of herbicide products can be determined and formulations can be used that will prevent unacceptable vaporization. Some aspects of volatility will be discussed briefly. The amount of drift can be affected by many factors, some of which can be controlled or adjusted to by the applicator. The more important aspects of drift will be explored in greater detail.

VOLATILITY

The vaporization potential of a herbicide can be assessed by the vapor pressure in relation to air temperature. The vapor pressure of a formulation may be 
different than that of the active ingredient. 2,4-D is an example of a herbicide that is formulated as inorganic or organic salts, both water and oil soluble, and as esters which are oil soluble and water emulsiviable. A quick review of these relationships may suffice to illustrate the problems of volatility. The chemical structure and reaction point of salts or alcohol radicals is shown in Fig 1 . The vapor pressures of the salts of $2,4-D$ as well as phenoxy, benzoic or picolinic acid compounds are very low; bioassays in greenhouse and field studies have been es tablished the lack of offtarget effects from any vaporization of these salt forms (1). FIGURE 1
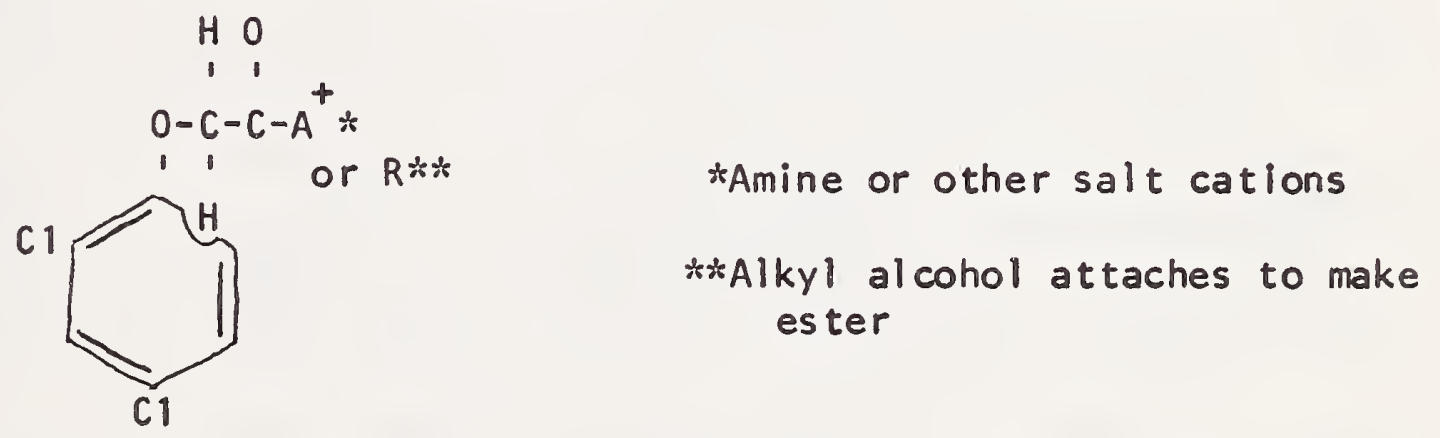
ester

2, 4-D has been marketed as esters formed from two to eight carbon or carbon + oxygen alcohols. The esters with two to four carbons have the highest vapor pressures and significant amounts can volatilize at temperatures of $60^{\circ} \mathrm{F}$. or higher. These short chain esters are called "High Volatile" (H.V.). The longer carbon chain esters are formed from six to eight carbon or carbon-oxygen alcohols and have significantly lower vapor pressures $(2,3)$. See Table 1 from date by Jensen and Schall (2).

Note the effect of temperature shown in Table 1 ; the figures for $25^{\circ} \mathrm{C}$ are representative of the temperatures under field conditions. The vapor pressure of the six to eight carbon chains are $1 / 4$ to $1 / 2$ those of the $n$-butyl ester, for example. The propylene glycol butyl ether ester (PGBE ester) of 2,4-D has about the same vapor pressure. Zimmerman et al. (1) showed by plant bioassays that the 
low volatile esters all caused about the same response and that they were many times safer than the H.V. esters. Field and lab studies have confirmed that movement of these ester forms can occur, but that the hazard from the low volatile esters is slight TABLE 1

\section{Vapor Pressures of 2,4-D Esters}

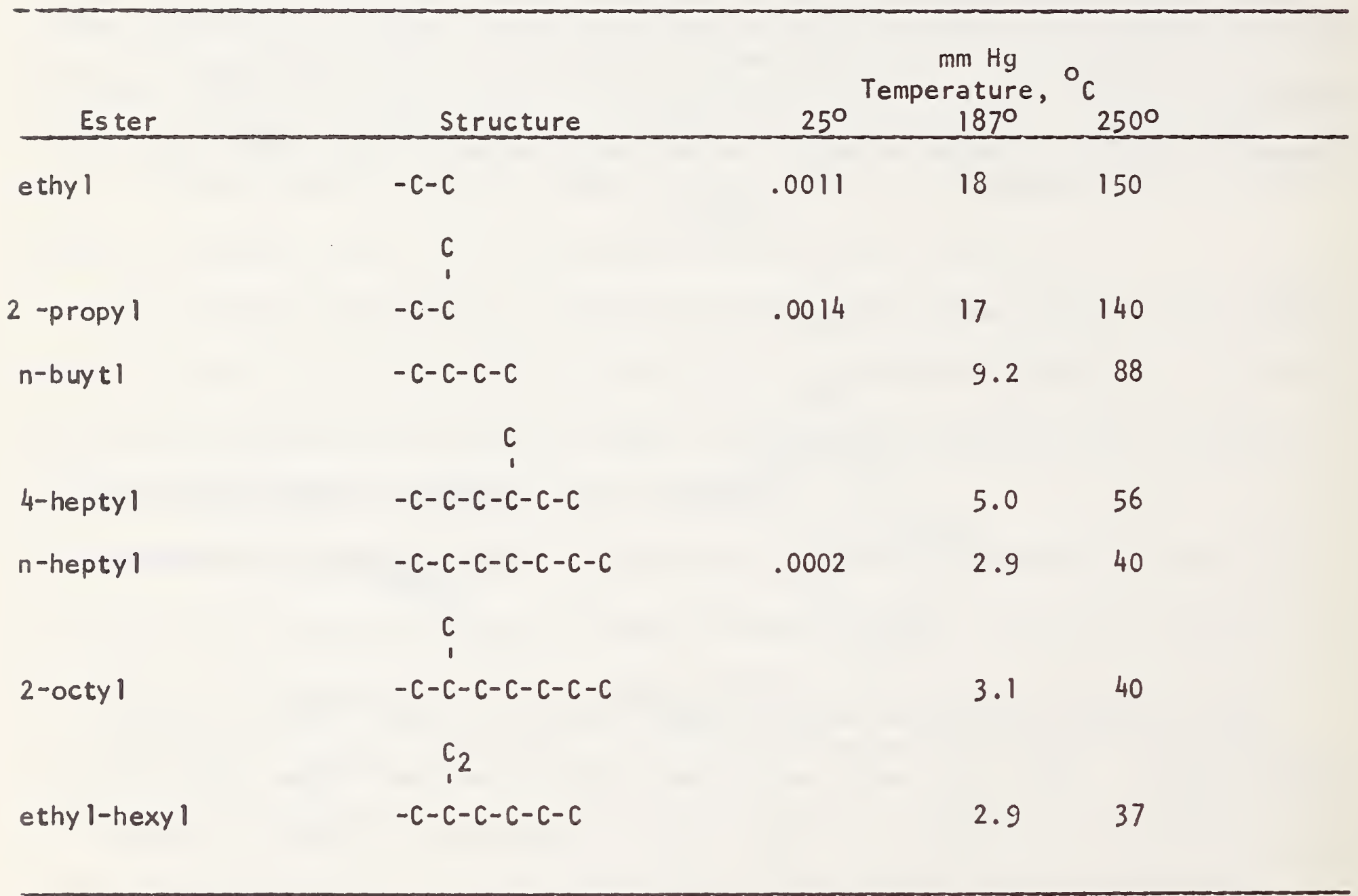

- From Jensen and Schall (2)

if the surface temperature for the first few days remains below $95^{\circ} \mathrm{F}$. High volatile forms can cause damage to susceptible plants outside the treated area, especially if large acreages are treated in a short period of time and day temperatures are above $60^{\circ} \mathrm{F}$. Usually volatilization of ester forms will occur only for three to four days after application because of the ester chain hydrolyzes off leaving the acid radical on the plant or other surfaces. The vapor pressure of $2,4-0$ acid is about the same 
as the low volatile esters, but the acid will react with plant constituents and should not vaporize appreciably even at high daytime temperatures in crop areas (40).

\section{DRIFT}

Herbicides often are applied in sprays with fixed wing aircraft or helicopters using a wide variety of systems. Spraying systems are becoming standardized because of more awareness of the problem and in some areas to conform to legal restrictions. Drift from ground applications varies in relation to nozzle types and pressures, spray patterns, and nature of the spray, but generally more drift occurs from aerial applications.

Herbicides require certain coverage or drops per unit area of leaf surface for efficient phytotoxic effect; the coverage requirements vary with the individual herbicide as well as adjuvants, such as oil or surfactants, that may be included in the spray. Several researchers $(4,5)$ have shown that effects of phenoxy herbicides on fol iage increase up to a density of about 70 droplets per square inch; the size of the droplet can be microscopic. Very little increase in efficiency is realized with more coverage. Picloram, amitrol and dicamba are translocated very readily in plants and it is probably that fewer contacts per unit leaf area are required. We know that drift is more likely to occur with finer droplets. Our objective as applicators is to use the volume rates and spray break-up that will provide adequate coverage for good weed or brush control with no detectable off-target drift. Assessing both the coverage needed and the drift hazard are very important. At times, reduced brush or weed control may have to be accepted or the application not made at all, depending on the circumstances. Applications, both aerial and ground, have waited days or weeks for safer weather conditions to prevent off-target damage.

The movement of fine spray particles off the target area, which we defined as "DRIFT", is dependent on a large number of influences; several are itemized for aerial applications in Table 2. Drift from ground applications is affected similarly, but usually to a lesser degree. 
off-target hazard is influenced by the type and form of the herbicide and the type of carrier as they affect the tendency to produce smaller droplets and increase active herbicide concentration on the drops. The hazard is related to the susceptibility of different plant species to small amounts of various herbicides.

The spray carrier can be water, oil-water emulsions, invert emulsions, foam or thickened water. Akesson and Yates (8) have shown that introduction of oily additives or surface tension reducing agents will result in small drops. Several viscosity increasing agents and other spray modifiers to increase drop size, such as invert emulsions, hydroxyethylcellulose, NORBAK ${ }^{B}$ particulating agent, NalcoTABLE 2

Factors Affecting Drift of Aerially Applied Herbicides

1. Herbicide - Nature and Rate.

2. Nature of Carrier - Water, 0 il/Water, $0 i 1$, etc.

3. Spray drop size spectrum, as affected by:
a. Nozzle type, capacity and pressure.
b. Nozzle orientation to airstream.
c. Speed of aircraft.
d. Viscosity of spray.

4. Application conditions:
a. Flight Path - level, rising, falling, or turning.
b. Boom location in relation to the wing or rotor.
c. Location of nozzles on the ship (boom).
d. Height of release of the spray.
e. Wind speed and direction.
f. Air Stability (vertical movement).
g. Number of contiguous passes.
h. Width of total spray pattern. 
5. Distance and direction to problem areas.

6. Screening effect of barriers - trees, etc.

7. Turning Area and Technique

Trol', and foams, have been introduced to reduce drift. These will be discussed later.

SPRAY DROP SIZE

Spray drop sizes are measured as diameters in microns $(\mu)$, but drops have a third dimension. These drop sizes are diameters of freely falling droplets and are only $1 / 3$ to $1 / 5$ the size of spots on collectors such as cards. Potts (9) has computed the number of droplets of different sizes produced by one gallon of spray and these are shown in Table 3. A droplet that has twice the diameter of another has eight times the volume or weight. The smaller droplet has about $1 / 2$ the surface of the larger droplet and, therefore, requires about $1 / 16$ the lifting force of air to remain aloft. These characteristics accentuate the drifting tendency of the smaller droplets.

\section{Table 3}

Size and Number of Droplets per Square Inch from One Gallon Liquid Uniformly over One Acre

Droplet Diameter, Microns $(\mu) \div$
No. Droplets per Square Inch

$\begin{array}{rr}25 & 80,625 \\ 50 & 9,224 \\ 100 & 1,164 \\ 150 & 347 \\ 200 & 142 \\ 300 & 43 \\ 1,000 & 1\end{array}$

* One micron $(\mu)=$ ab. $1 / 25,400^{\prime \prime}$. 
Droplet size is very important in drift; water droplets in various components of the atmosphere and their drifting potential are noted in Table 4 (7). Droplets in the size range of 20 - $30 \mu$ or smaller remain suspended (fog); in herbicide sprays, these droplets may be nearly invisible in the air. Of course, these as well as larger droplets, are subject to air movement. The larger droplets are moved less horizontally, but still may move considerable distances; note that $100 \mu$ droplets can move laterally $408 \mathrm{ft}$. in a three mph. wind while falling ten feet. Some applications to utility lines or forest sites are made 100 to 300 feet above the ground, which magnifies the drift potential greatly.

\section{Table 4}

Spray Droplet Size and Its Effect on Spray Drift

\begin{tabular}{|c|c|c|c|c|}
\hline $\begin{array}{c}\text { Droplet Diameter } \\
\text { Microns }\end{array}$ & $\begin{array}{l}\text { Type of } \\
\text { Droplet }\end{array}$ & $\begin{array}{l}\text { 10. of Drops } \\
\text { er Sq. Inch } \\
\text { rom one gal. } \\
\text { Spray/Acre }\end{array}$ & $\begin{array}{l}\text { Time Required } \\
\text { to fall } 10 \mathrm{ft} \text {. } \\
\text { in Still Air }\end{array}$ & $\begin{array}{l}\text { Distance Droplet } \\
\text { Will Travel in } \\
\text { Fall ing } 10 \mathrm{ft} \text {. } \\
\text { with } 3 \mathrm{mph} \text { wind }\end{array}$ \\
\hline $5($ to 30$)$ & Fog & $9,000,000$ & $66 \mathrm{~min}$. & 3 miles \\
\hline 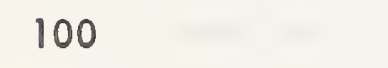 & Mist & 1,164 & $10 \mathrm{sec}$ & 408 feet \\
\hline 500 & Light Rain & 9 & $1.5 \mathrm{sec}$ & 7 feet \\
\hline 1000 & Moderate Rain & 1 & $1 \mathrm{sec}$. & 4.7 feet \\
\hline
\end{tabular}

--Adapted from Akesson and Yates (25) and Kl ingman (7)

The effect of a five mph crosswind on horizontal displacement of different size drops is shown graphically in Fig. $2(10)$, assuming no change in size during fall. 
FIGURE 2

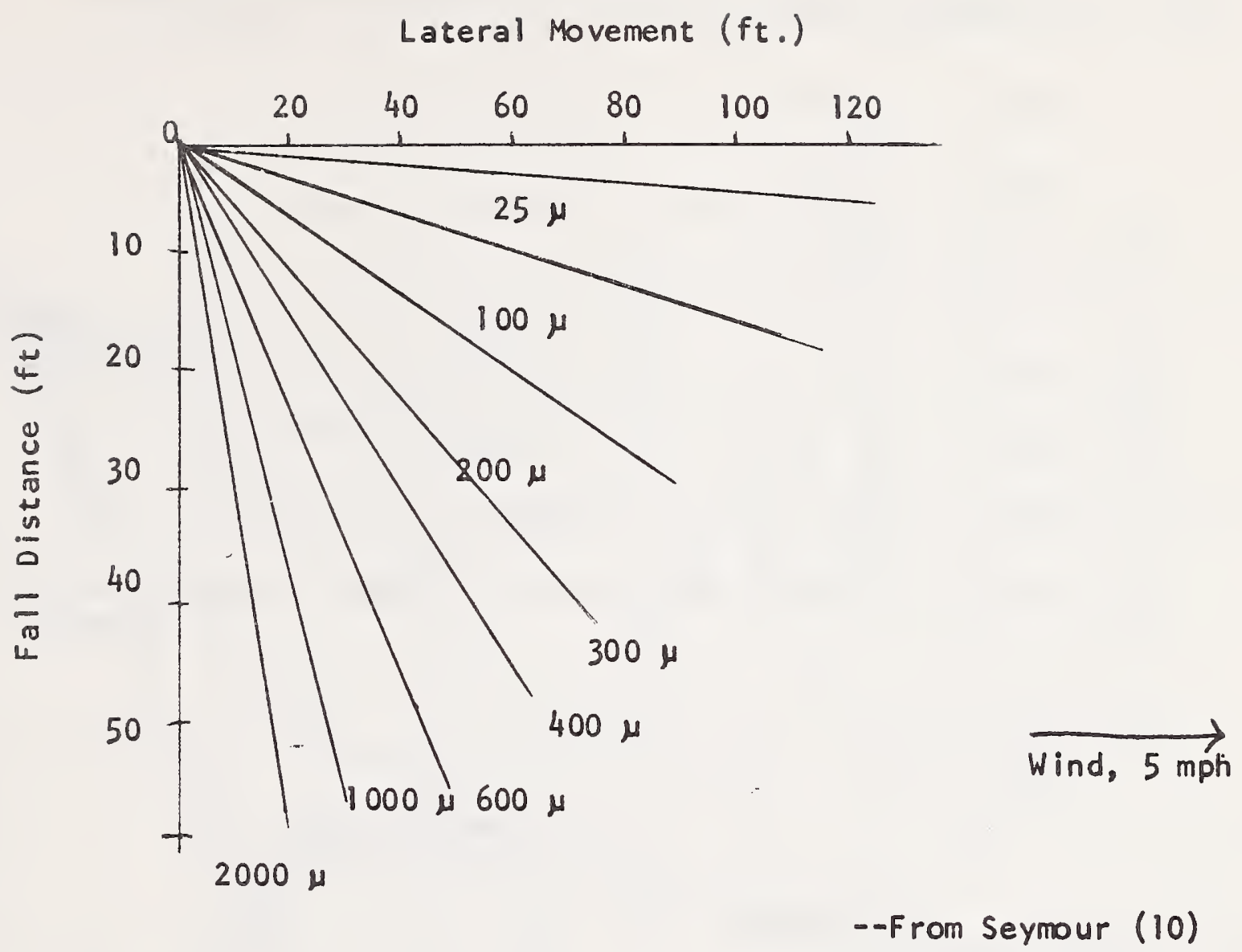

Research has shown that there is a rapid decrease in drift potential of drops as they increase from 20 to about 150 or $200 \mu$. Thereafter, as the drops enlarge there is much less change in the drift potential. The critical size where this difference occurs is larger with higher wind speeds, but lies in the range of 150 to $250 \mu$ for speeds of one to eight mph $(11,12)$; Fig. 3 shows this relationship. Drift is decreased greatly by increasing drop sizes to about 150 to $250 \mu$, and much less after that. The size range from 200 to $400 \mu$ allows adequate coverage with reasonable volume rates and is a good size to seek for spraying herbicide. 
FIGURE 3

Relation of Spray Drop Size to Drift at Different Wind Speeds

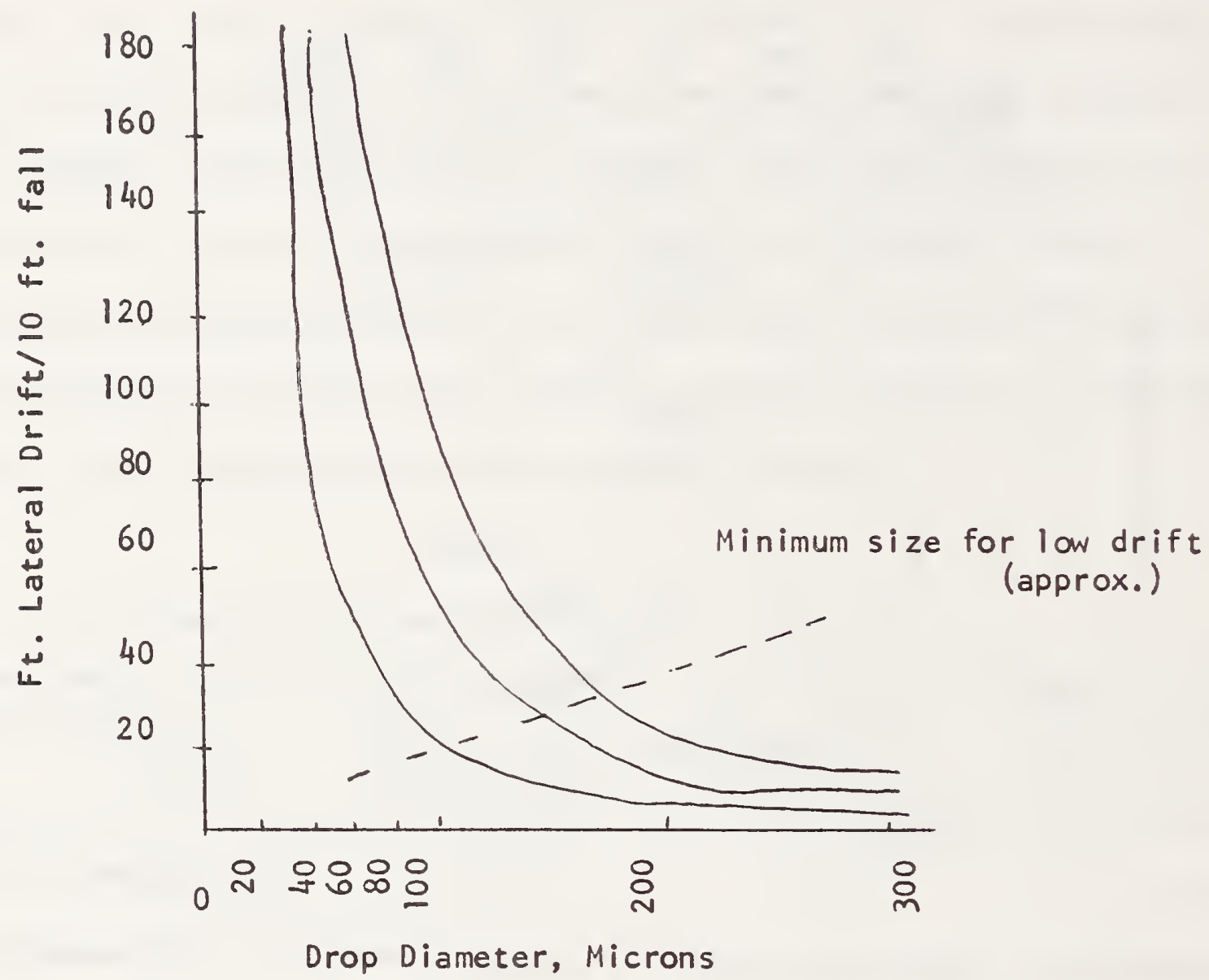

- -From Byrd (11)

With water carriers, spray drop size may decrease during fall because of evaporation unless a non-evaporative film, such as oil, surrounds the drops. Smaller droplets falling into air of relative humidity less than about 80 percent may evaporate before hitting the target (13). Fig. 4 shows the effects of evaporation on water droplets 80 to $200 \mu$ in diameter falling through air with a 50 percent and 70 percent relative humidity with a one mph crosswind. Note that in air at 50 percent relative humidity, the 80 to $120 \mu$ drops disappeared with less than a seven foot drop; the smaller spray droplets disappear sooner. The herbicide in these drops will not fall out until picked up in falling rain. The $200 \mu$ drops may reach the ground, but will certainly be progressively smaller and more subject to drift. The droplets evaporate more slowly in 70 percent relative humidity and faster in lower relative 
FIGURE 4

Effect of Relative Humidity on Lateral Movement of

Spray Droplets in a One mph Wind

Lateral Movement in One mph Wind, $\mathrm{ft}$.

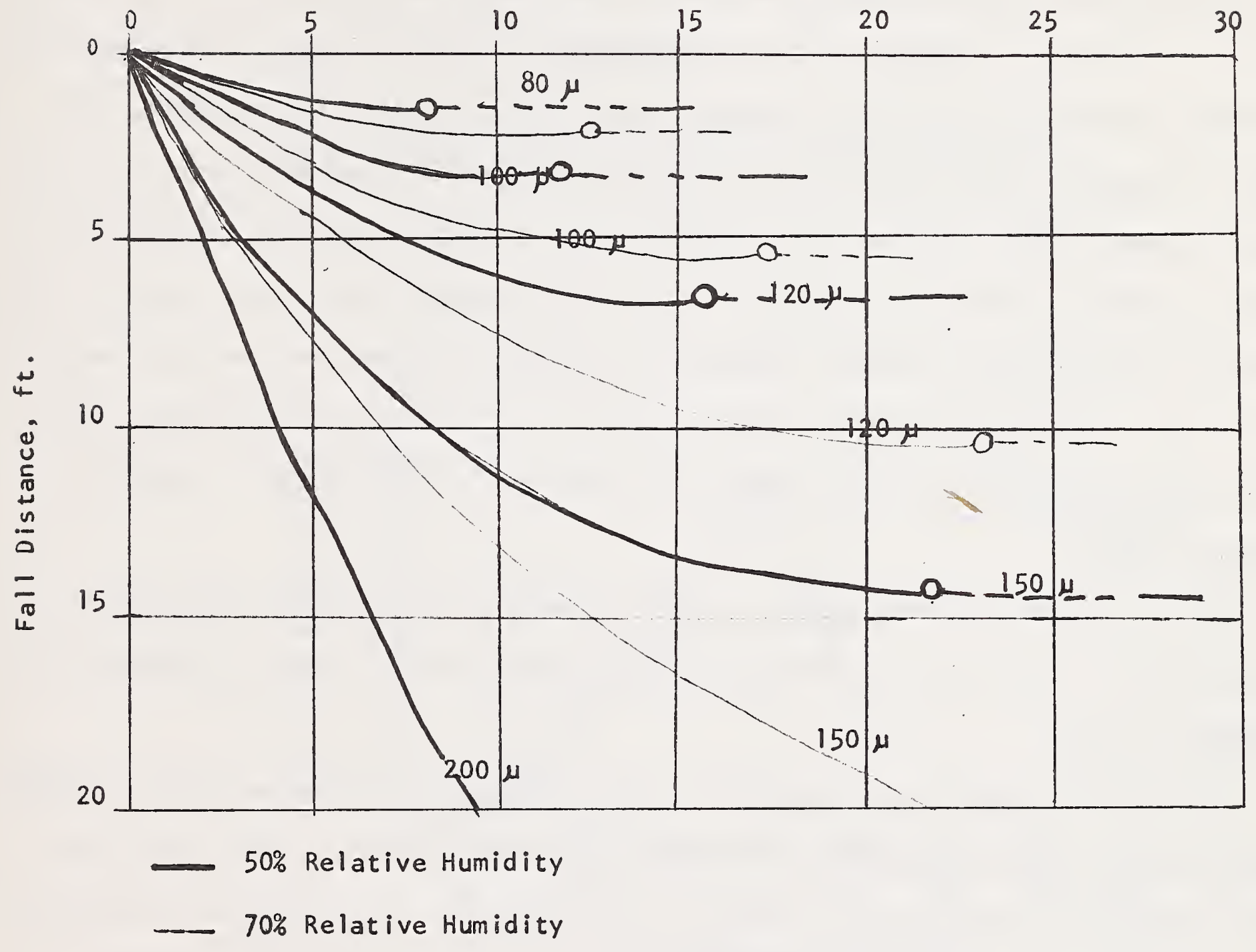

--Adapted from Seymour and Byrd (13)

humidity. It is evident, then, that as water droplets fall through air with a water deficit (less than $100 \% \mathrm{RH}$ ), they will be decreasing in size and will more more or less as indicated in Fig. 4. Addition of oils or surfactants may reduce this evaporation somewhat, but usually there will be some loss in water as they fall. 
As liquids are forced through orifices under pressure, they speed up. There usually is some turbulence in the nozzle or spray dispenser that exerts breakup forces on the liquid. As it leaves the nozzle, it may be directed into a fan or a hollow or solid cone pattern that creates added shear. The liquid extends into sheets--either flat or circular--or threads. These stressed liquids develop waves in the sheets or threads, and break up resulting in larger drops with many satellite droplets. The shear is caused by the pressure and turbulence, such as internal deflecting vanes to induce a cone or any diviation from a solid stream. Circular orifices without swirl plates produce the least disturbance and, therefore, larger drop sizes. Various size nozzles under different pressures change the average drop size, but the size range is still great. Certain devices have been developed to reduce the range of drop sizes, such as the Microfoil ${ }^{2}$ boom, the Raindrop ${ }^{3}$ nozzle and Direct-A-Spray ${ }^{2}$. These will be discussed later.

When a liquid is forced apart, it usually forms a large range of drop sizes. Most nozzles or spray devices produce a distribution of drop sizes, as indicated in Fig. 5 .

The pattern shown by the dashed lines (Fig. 5) would be close to ideal. Certain mechanical or electrical devices will produce fairly uniform drop sizes; the mean drop size of the spray must be increased so the amount in fine particles (less than 50 to $100 \mu)$ will be below levels that may cause significant off-target effects.

2 Registered trademarks of Amchem Products, Inc., Anbler, Pennsylvania 3Registered trademark of Delavan Mfg. Co., West Des Mo ines, lowa. 


\section{FIGURE 5}

Typical Droplet Size Distribution from Spray Hozzles

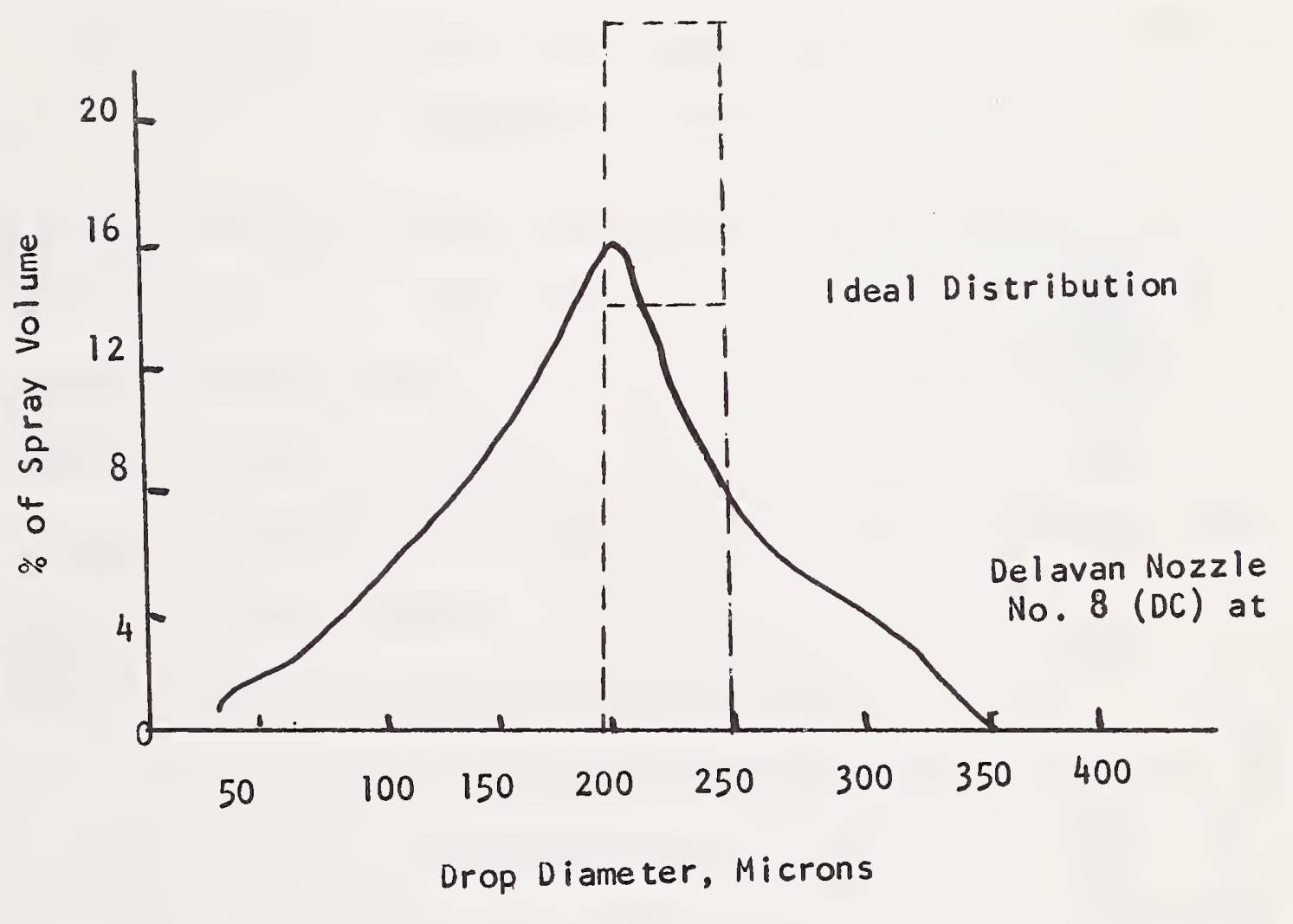

--Adapted from Tate and Janssen 
Because of the wide range of drop sizes in sprays, various methods are used to designate this factor. The one probably used most is a size at which half the spray volume is in drops above and half below this figure; it is called the "Volume Mean Diameter" (VMD). This results in a much greater number of drops in the smaller half of the spray. Another term is the "Number Mean Diameter" (NMD), which indicates the size at which $1 / 2$ the number of droplets produced is larger or smaller. If drop size counts are made for certain spray systems, the drift potential can be assessed by noting the percentage of spray in the size range below 100 to $150 \mu$, using a cumulative graph of the spray volume in the different size ranges, as indicated in Fig. $6(15,33)$.

\section{FIGURE 6}

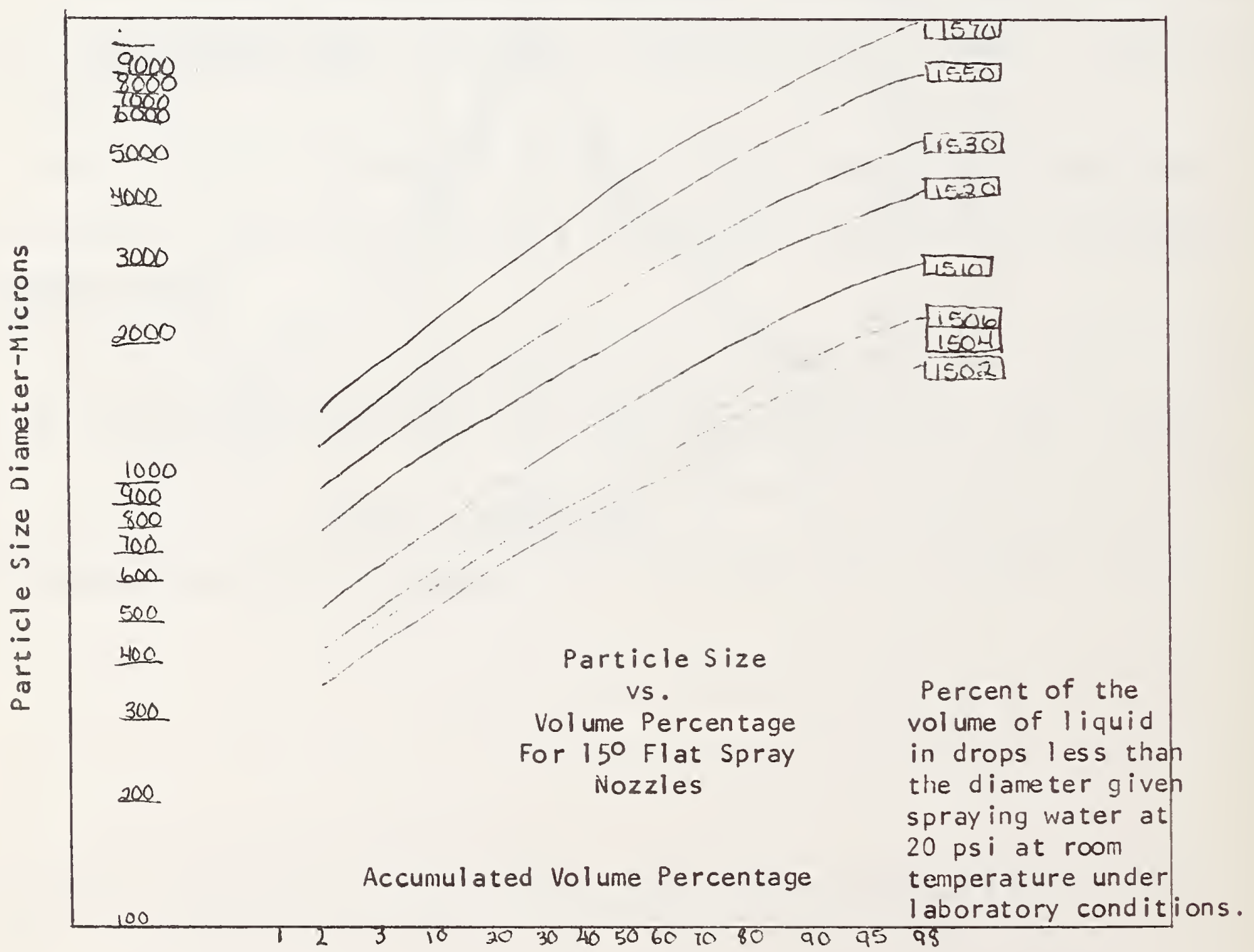


Drop sizes in sprays change significantly and inversely with pressures, as shown in Fig. 7 (34). Pressures in the range of 20 to 35 psi at the nozzle are usually adequate to produce the desired spray pattern and will result in much less drift then with higher pressure. Fig. 7 shows that there is less effect of pressure on drop size with smaller size orifices.

Tate and Janssen (16) found that the mean drop sizes of sprays from cone, fan or deflector nozzles were essentially the same if the fan or cone angles were the same. The drop size was almost directly proportional to the flow rate at equal pressures as plotted in Fig. 8. References to drop size determinations for various nozzles by Spraying Systems Co. (34) indicate that the wider angle fans or cones produce smaller droplets, as plotted in Fig. 9. Other data and experience show that a jet (round orifice) will produce the largest size drop for a given flow rate and pressure--due likely to the fact that there is less shear stress on the liquid. Also, certain nozzles such as the Spraying Systems Low Pressure (LP) nozzles, can produce a good pattern at pressures from 10 to 20 psi. Spraying Systems type TG and GG solid cone (full jet) nozzles produce larger drops than fan or hollow cone nozzles with equal core or fan angles, flow rates and pressures (34), as shown in Fig 10 .

The Raindrop nozzle recently introduced by Delavan Mfg. Co. apparent ly reduces the range of particle size by providing a chamber outside the metering orifice to induce coalescence of the small drops. Field tests are progressing now; data from manufacturer's tests indicate that drift can be reduced in ground applications by this means without sacrificing much in coverage.

Foam nozzles are special aspirators with fans, jets or other patterns that are used with certain foaming agents that incorporate air to expand the spray volume 4 to $600 \%$ (18). Drift of foam sprays will be discussed in the section under"Adjuvants".

The microfoil boom (Amchem Co.) uses a large number of holow needles projecting back from a small air foil boom mounted on a helicopter. These tubes produce few 
FIGURE 7

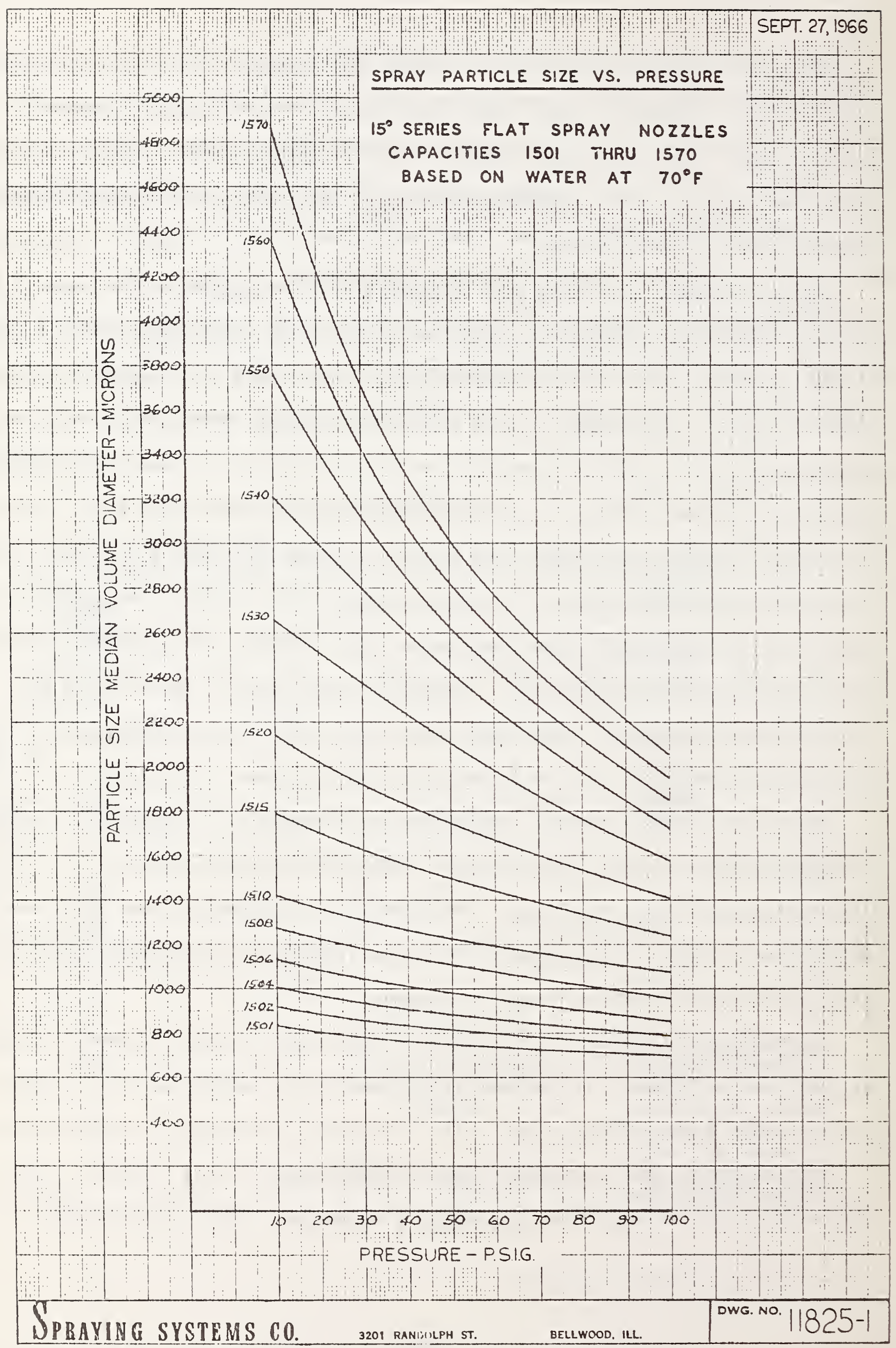


fine drops and the air stream moving around the air foil helps coalesce them. It is FIGURE 8

Droplet Size vs. Nozzle Flow Rate

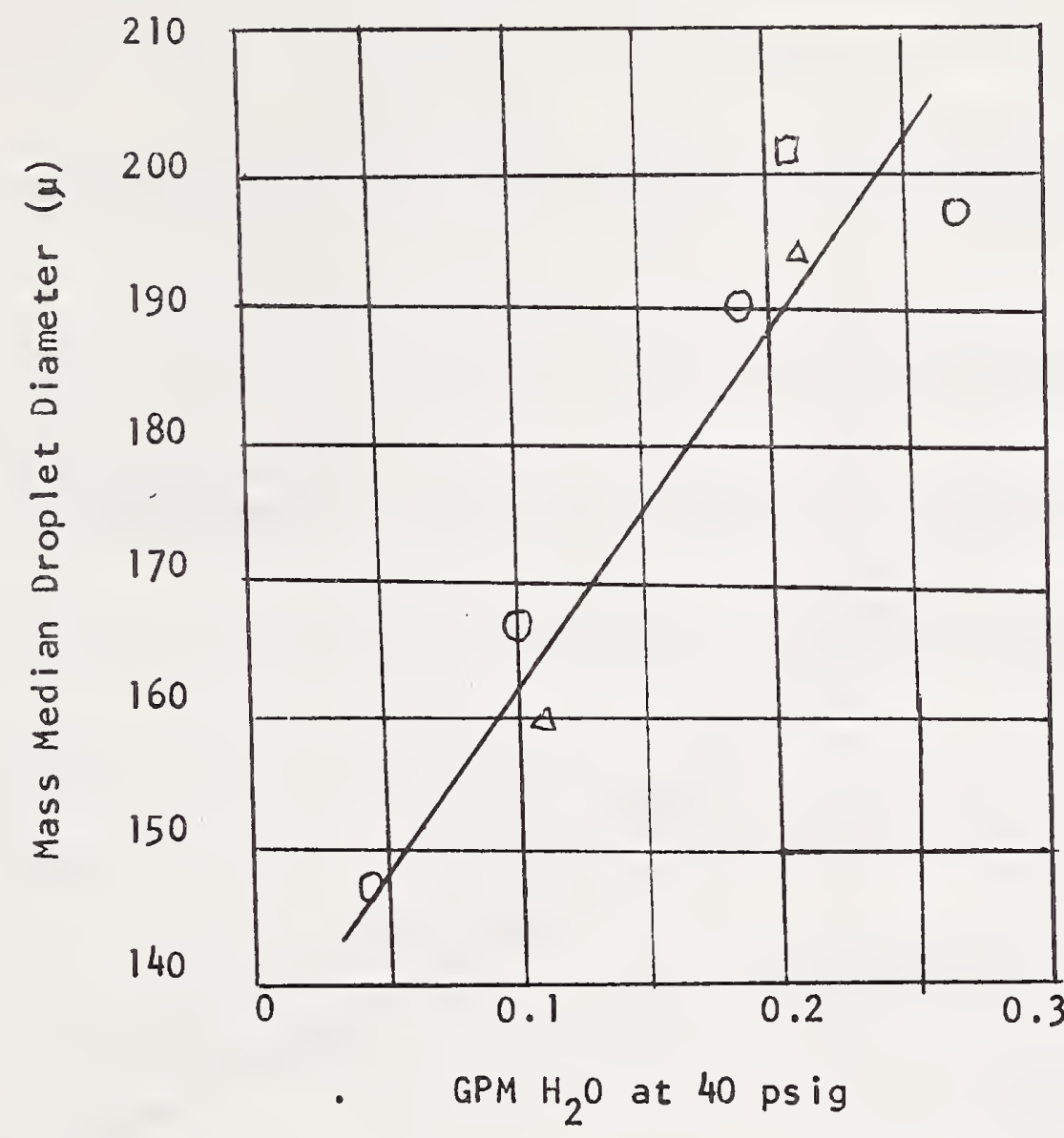

Cone Spray Flat Spray Flooding

- -From Tate and Janssen

not suitable for use with fixed wing aircraft because they operate at much higher speeds and cause shatter of the large draps. The range of drop size is greatly reduced and drift is minimal if the orientation to the direction of flight is correct; but the average drop size is too large for low volume ( 5 gpa or less) applications. Flow rate through the small tubes $\left(0.013\right.$ to $\left.0.029^{\prime \prime}\right)$ is affected by viscosity of the spray. Also the spray requires extensive filtering to prevent plugging. The DirectA-Spray (Amchem) is a rotating device on ground sprayers that meters the liquid to short tubes turning fast enough to throw the drops out as much as $24 \mathrm{ft}$. Drift is minimal with this system, and coverage is fairly uniform; spray droplets are quite large. 
FIGURE 9

Relation of Droplet MVD, Spray Angle and Pressure with Water at Flow Rate of $0.2 \mathrm{gpm}$ at $40 \mathrm{psi}$

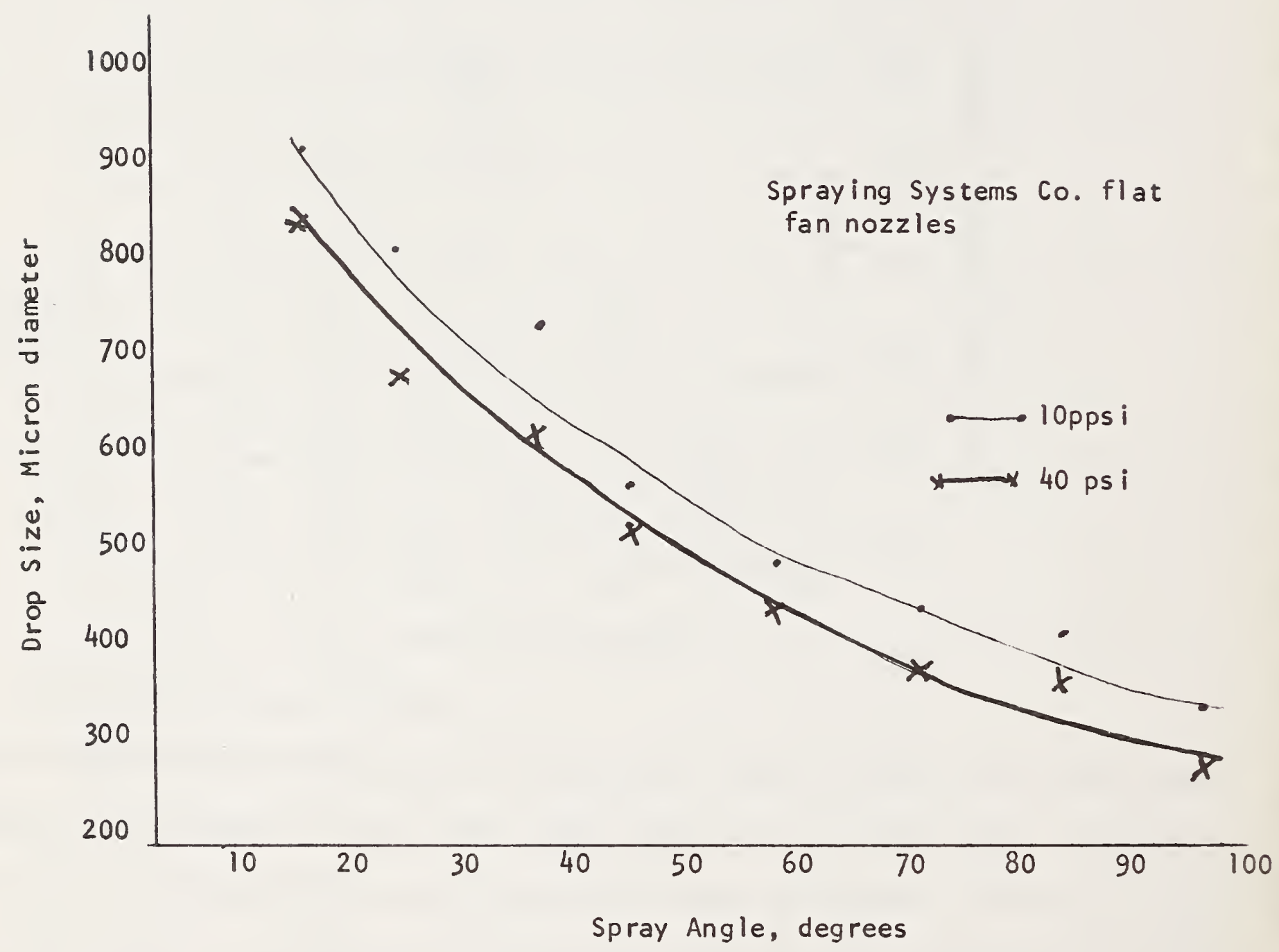

- -Adapted from Spraying Systems Co. drop size charts (34). 


\section{ESTIMATED PARTICLE SIZE-(MICRONS) -FOR STANDARD SSCO NOZZLES}

(Nozzles spraying water at 40 PSIG at room temperature under laboratory conditions)

WHIRLJET

SIZES

HYDRAULIC

ATOMIZING

SIZES

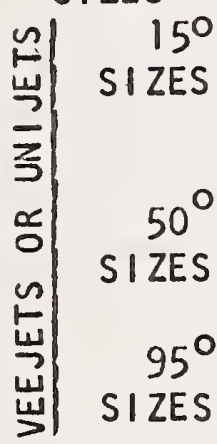

FULLJET

SIZES

AIR

ATOMIZING

NOZZLES

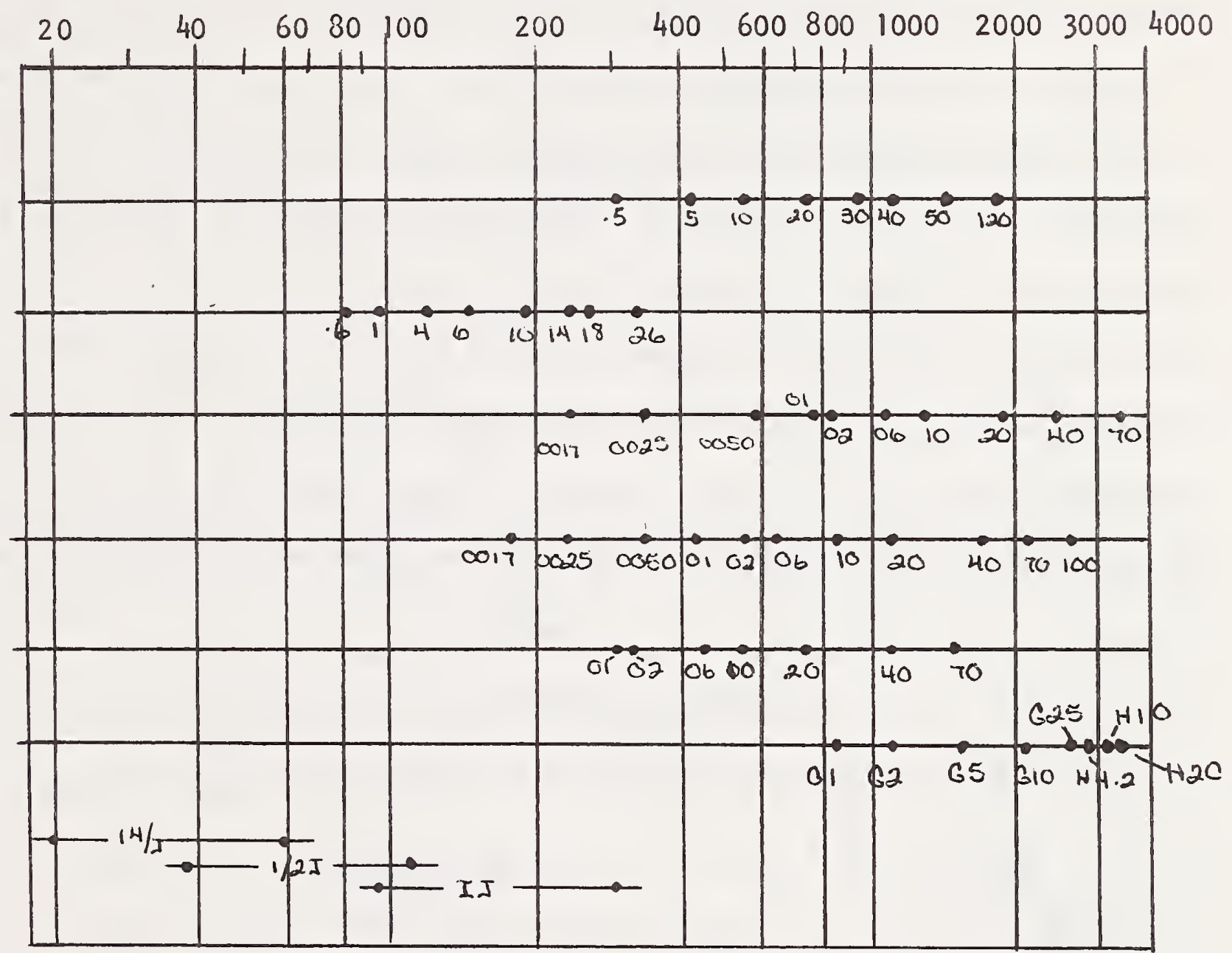

M.V.D. Particle size data is based on volumetric measurements where $50 \%$ of the liquid sprayed is in drops smaller than the given number and $50 \%$ of the liquid is in drops larger than the given number.

$$
\text { - -From Spraying Systems Co. }
$$

Volume rate of spray has been a base for prescribing drift control systems. This factor is important only if the nozzle sizes, pressures or other parts of the system are specified to achieve coverage along with minimum drift. More nozzles of the same type under the same operating conditions will produce more drift; conversely, fewer drift (allower volume rate). Volume rate limitations should never be specified without including minimum flow rate and certain type nozzles and mounting angles. 
As the spray leaves nozzles mounted on an aircraft, travelling at speeds over about $25 \mathrm{mph}$, it is subjected to impact of the air through which the nozzle is moving; this shear force will cause more breakup of the drops. Drop size is not effected much with ground application from a vehicle moving five to ten mph. There is a slight impact at speeds of 10 to $20 \mathrm{mph}$. At 30 to $120 \mathrm{mph}$, the speeds employed by aerial applicators, the effects become increasingly important with speed; Fig. 11 , from work by Is ler and Carlton (17), shows the average drop size using a U-50120 nozzle (flat fan) at 25 psi at speeds from 80 to $200 \mathrm{mph}$. In this, as in tests with other nozzles, there was an inverse ratio of drop size to speed; a $250 \%$ increase in air speed caused a reduction to $40 \%$ the original drop size. As indicated above, the drops below about $150 \mu$ are more subject to evaporation loss of water and the drifting potential in this range is at least 16 times the inverse ratio of the diameters.

FIGURE 11

Effect of Airspeed on Atomization

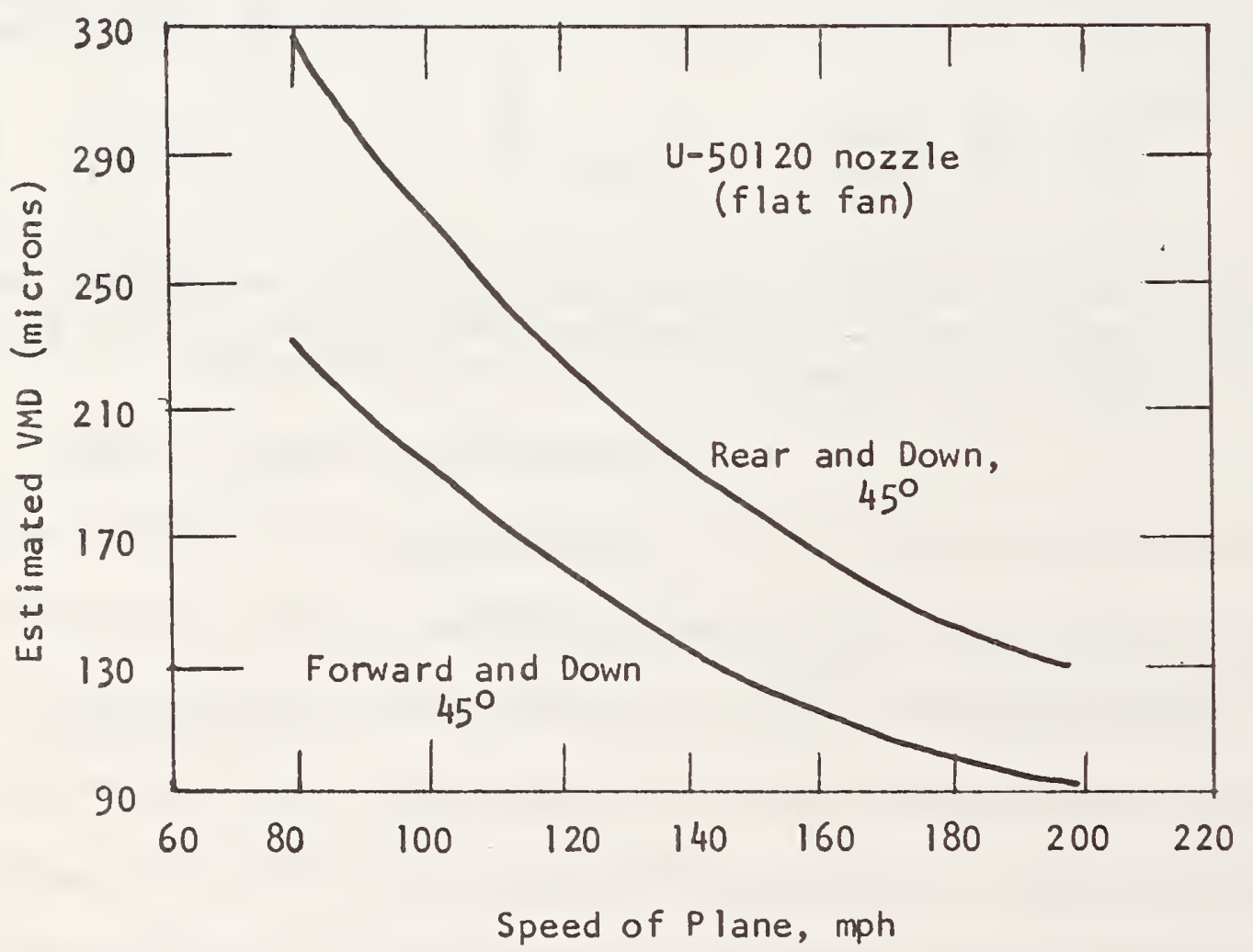

- From Isler and Carlton (17) 
and dispenses particles in a 300 to $500 \mu$ range. This produce requires special equipment and handling, and has very limited utilization at present.

Invert emulsions produce a water-in-oil emulsion by using certain agents in the oil phase and by sequence mixing. Viscosity can be increased by increasing the water-to-oil ratio and by added shearing to a consistency of mayonnaise; with proper nozzles, excellent drift control is possible, as reported by Laning et al. (19). Also, invert emulsions will reduce evaporation of the spray droplets in air because of the oil film, regardless of drop size. Thin invert emulsions, however, may actually increase detectable drift compared to water carriers (33). The spray can be tank mixed or flash mixed in the line from tanks to the pump with the proper equipment. Positive displacement pumps are needed to control shear, maintain desired viscosity and move the thickened liquid uniformly. Considerable expertise in the technology of invert emulsions is required to use these systems efficiently. Nalco-Trol ${ }^{1}$ (also Lo-Drift ${ }^{2}$ and others) is a polyvinyl water soluble polymer that increases spray viscosity but has other visco-elastic properties that can decrease fine droplets. Yates et al. (21) found that Nalco-Trol solutions through higher shear nozzles, such as $06-46$ hollow cone, produced a larger average drop size than with water, but there were more fines below $100 \mu$. The jet 06 orifice, however, gave marked reduction in fine drops. Apparently, increased shear in the nozzle increases spray breakup disproportionately with this product. Aerial tests by planes and helicopter confirmed the effect of $\mathrm{Nalco-Trol}$ at 0.15 to $1.00 \%$ in reducing drift, especially with low shear nozzles $(21,29,35)$. It was necessary to add an anti-foam agent Nalco No. 2151) at 0.1 to $0.2 \%$ to sprays containing higher rates of surfactant, such as with TORDON 101 Mixture, to prevent formation of bubbles at the nozzle. This product is the only drift control agent that is cleared for use with herbicides on cropland (36). 
Hydroxyethylcellulose, marketed as $V_{i s t i k}^{4}$ or HEC/B, is another nonreactive agent to increase viscosity. This product was included in tests by Yates et al. (21) which indicated that, at the rate of $0.6 \%$, it is effective in materially reducing fine droplets. It is a powder that must be added to the solution carefully and five to ten minutes are required to allow thickening; but it can be sprayed or transferred with any kind of pump. Availability in agricultural chemical markets is questionable.

Marketers of air emulsion systems (foams) have claimed drift control with several herbicides $(37,38)$. Because of the expansion ratio (five to seven times) of the wet foam, the coverage may be better than with a similar liquid volume of spray. However, Ashford (26) reports that in field tests with 2,4-D and paraquat, weed control with the foam systems was poorer than with standard nozzles.

Evaluations of drift in the air and surface deposits with jet nozzles back on a fixed wing plane at $90 \mathrm{mph}$ compared foam and water carrier (30). The resul ts showed much higher levels of drift in the air and as fallout from 165 to $2600 \mathrm{ft}$. downwind with the foam systems. Outputs were the same in both systems. Wind tunnel studies by Bouse and Leerskov (37) also showed that these foams produced more drift than did water without additive.

EFFECTS OF AIR ON DRIFT

Air can affect spray particles by shattering larger drops or carrying smaller droplets to off-target sites. As spray is emitted from nozzles moving through air at over about $30 \mathrm{mph}$, they are subject to more or less air blast that will break up droplets, as shown in Fig. 11. Nozzles can be oriented so the drops are travelling into, across or with the air flow past the aircraft. Of course, there will be more air shear or droplet breakup as the spray stream is directed into the air flow.

It is not enough to point a nozzle backward with the airstream, however, if it produces a cone or fan that is still subject to the air blast around the nozzle body. Wider cones or fans will be more subject to this shear. Data from Yates (30) show a

\footnotetext{
4

Product of Hercules Incorporated, Wilmingtom, Delaware
} 
distinctly smaller drop size for a $06-45$ vs. a D6-46 vs. a $D 6$ alone, all pointed back on a plane $(150 \mu v s .450 \mu$ vs. $900 \mu$ drop sizes). These results are the bas is for specifications in several state regulations for jet nozzles pointed back to reduce drift.

The speed of helicopters is generally less and air shear is reduced; also the spray boom can be mounted on the skid toe ahead of the air disturbance caused by the rotor. Nozzles on helicopters at speeds of less than about 55 mph can be pointed down with a little more effect on spray break-up compared to pointing them back.

Air currents induced by the wings or rotors of aircraft can affect drift greatly. Even helicopters have significant rotor tip vortices which accentuate as the forward speed increases above about $25 \mathrm{mph}$. Yates et al. (23) determined how the air moves around agricultural aircraft; the lateral airstreams induced by a Bell helicopter at $55 \mathrm{mph}$ and a fixed-wing aircraft; at $80 \mathrm{mph}$ are shown in Fig 12. Note the difference between right and left vortices on the helicopter; this is caused by the forward and rear motion of the rotor on opposite sides. Also note the slopes of the airstreams at various distances out from the center. If any spray particles become entrained in the wing or rotor tip vortices, they can be carried aloft and be widely dispersed. There is more chance of finer droplets being carried in these vortices and this tendency increases greatly as the airstreams become more horizontal farther from the center. For this reason, nozzles should be located no farther out than $2 / 3$ to $3 / 4$ of the distance from the center to the end of the rotor or wing.

other work has shown that the spray boom should be located as far below the rotor or wing vortices on the spray. On a helicopter, the spray boom should be located as as far forward as possible to reduce the effect of the rotor or wing vortices on the spray down below the influence of the rotor wash. Some aerial applicators try to "push" the spray out as far as possible to they can fly wider swaths, such as in spraying sagebrush with 80 to $100 \mathrm{ft}$. swaths. They should recognize that they may 


\section{FIGURE 12}

Comparison of Air Currents in Wake of a High Wing Monoplane and a Helicopter
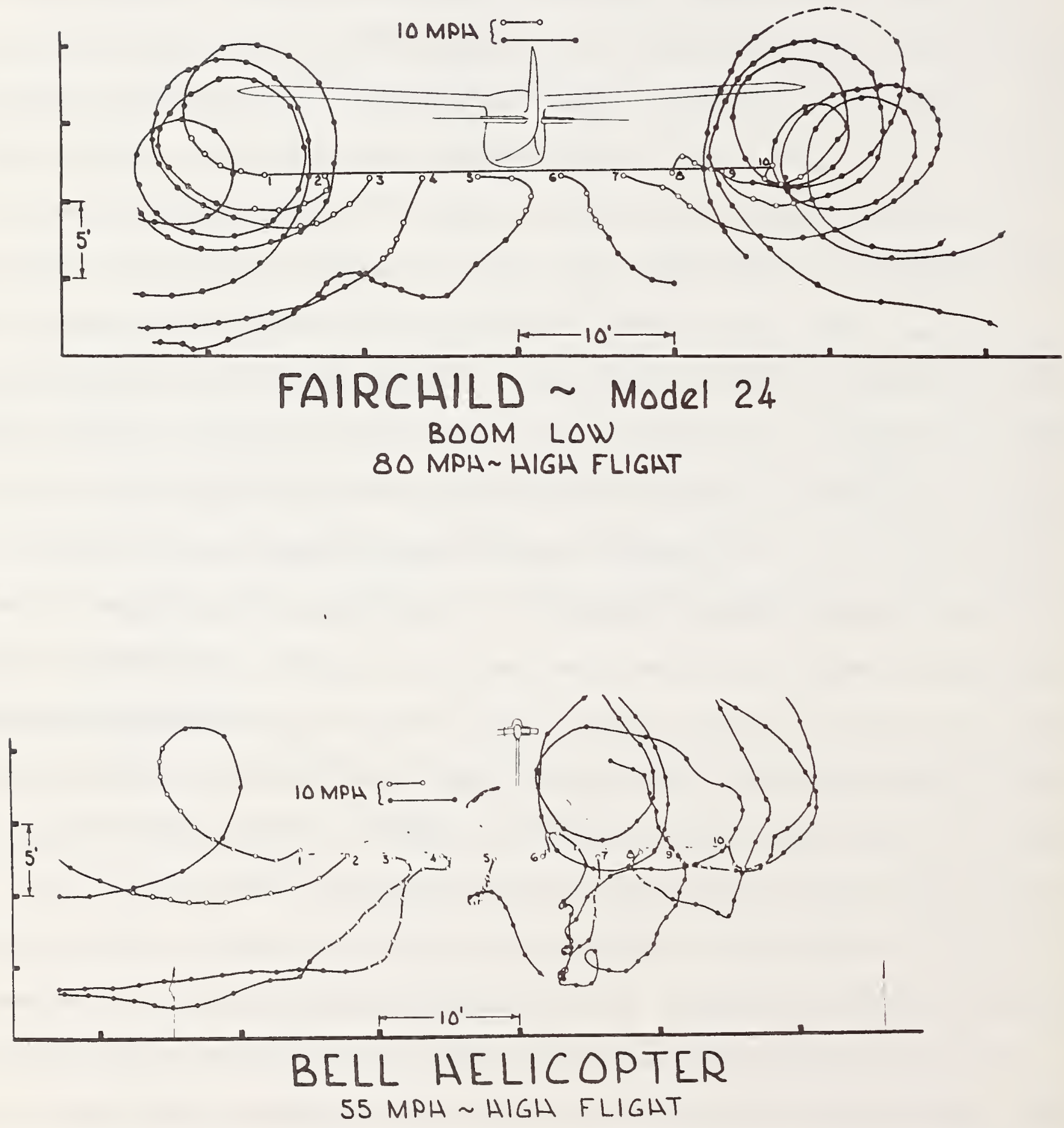

--From Yates et al. (23) 
be producing fine droplets and air conditions that will increase drift and loss of herbicide greatly.

These wing or rotor tip vortices are affected also by the attitude of the aircraft. The diagrams in Fig. 12 were for level flight. If the aircraft is climbing, there will be more down wash and less tendency to pull spray up into the vortices. If the craft is descending, the wing or rotor tip vortices will pull more spray aloft; various portions of the spray pattern will be disturbed more also. Level or slightly ascending flight is usually best to alleviate both effects. The pilot should level off for each pass before turning on the spray.

When using jet (round orifices) nozzles to reduce drift, uniform dispersal may be limited unless the elevation is sufficient to allow the jet streams to spread out. The patterns from D6 jets at about nine inch spacings or with $06-46$ (with swirl plates), both pointed back, on a helicopter flying $60 \mathrm{mph}$ five feet high are compared in Fig. 13 (23). Note the sharp difference in deposits across the pattern with the jets compared to those with the $06-46$.

In other work (24), it was found that a good pattern with distinct edges was obtained with 04 jet nozzles at 11 inch spacings on a helicopter when flying at $45 \mathrm{mph}$ and ft. elevation. Usually an elevation of 10 to 15 feet with smaller jet nozzles pointed down will avoid streaking if the nozzles are about 12 inches apart.

Since the movement of spray droplets after they leave the aircraft influence is dependent mostly on the general air movement and smaller drop sizes are affected more, it is important to consider these effects on drift potential. Air can move horizontally or vertically in response to local or air mass differences in density. Air temperature differences cause most of the changes in air density; cooler air is more dense and tends to displace adjacent warmer air. As the soil surface warms from the sun on a clear morning, the air immediately above it becomes lighter and the cooler (more dense) air around it pushes the lighter air aloft. This may happen over a rather wide area if surface con- 
Spray Patterns from D6 jet and D6-46 Nozzles

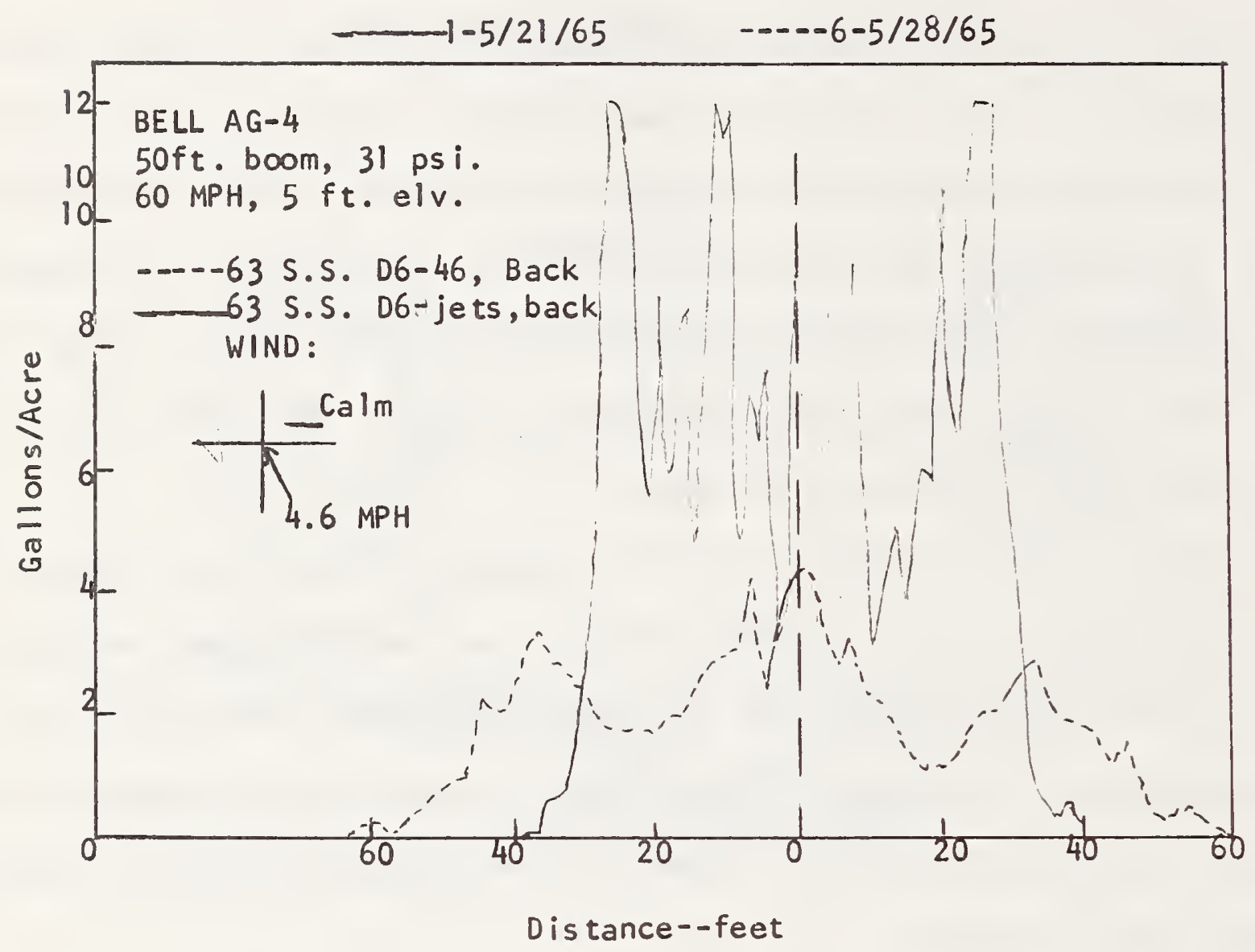

- -From Yates et al.

ditions are uniform. Usually there are sufficient variations so that heating is uneven and small rising air columns will develop over warmer sports. Of course, the rising air can affect the distribution of small droplets seriously. Aerial applications of 2,4-D to grain and sagebrush at volume rates of $1 / 2$ to 4 gpa are usually stopped when air temperatures reach 70 to $85^{\circ} \mathrm{F}$. because of erratic surface heating.

Air stability concerned with drift is related to the degree of vertical mixing in the layer of air from the ground to a few feet above the point of spray release. A condition in which little or no vertical mixing occurs is most conducive to off-target drift because the fine spray particles will continue to fall slowly and not be dispersed aloft. Stable air conditions are induced usually by cooling of the air close to the soil surface from radiation 
near sunset and through the night. The lower few feet of air in this situation has a lower temperature than aloft. It is called an "inversion" and various degrees or depths of inversions can be observed. They are usually most pronounced shortly before or after sunrise; surface heating through the morning will increase air temperatures below the inversion until a "normal" lapse is established. At that time, and above the inversion, the air temperature normally decreases $3.2^{\circ} \mathrm{F}$. for every $1,000 \mathrm{ft}$. of elevation, which is the normal lapse rate. If it decreases faster than that, an unstable condition exists and vertical mixing will occur rapidly. Under normal or higher lapse rate conditions, very fine particles of spray would be dispersed aloft. Generally, they will be degraded in the air by photodecomposition. Couts and Yates (15) reported that the degree of air stability is affected also by wind speed in the lower levels of air. They developed a formula to quantitate this factor into a Stability Ratio (S.R.) number using the temperature difference from eight to $32 \mathrm{ft}$. and the wind speed at $16 \mathrm{ft}$. elevation. The drift potential in the treatment area cf. air stability can be predicted fairly well. It also helps to relate different experimental drift results so they can be compared more readily even though wind speeds may vary.

Four different air lapse conditions and effects on spray dispersal are diagrammed in Fig. 14. Spray released below the top of an inversion is likely to persist and fall out over a greater distance than in any other type. Spray released above an inversion will fall through, perhaps erratically, but some fines will be dispersed aloft. The degree of vertical mixing and consequent reduced fallout of fine drops is directly related to the strength of the lapse. In drift evaluations of pesticides, Akesson and Yates (25) found three times as much fallout of spray at 100 to $200 \mathrm{ft}$. downwind in stable air compared to unstable air; at 1,000 to $2,000 \mathrm{ft}$, there were ten times more deposits in stable as in unstable air.

The practical implication of the air stability factor is related to the assumption that "still", cool air provides the best condition for spray application. An inversion 
FIGURE 14

Schematic, Vertical Profiles of Fine Spray (oil smoke) Plumes

Released by Plan Under Different Thermal Conditions
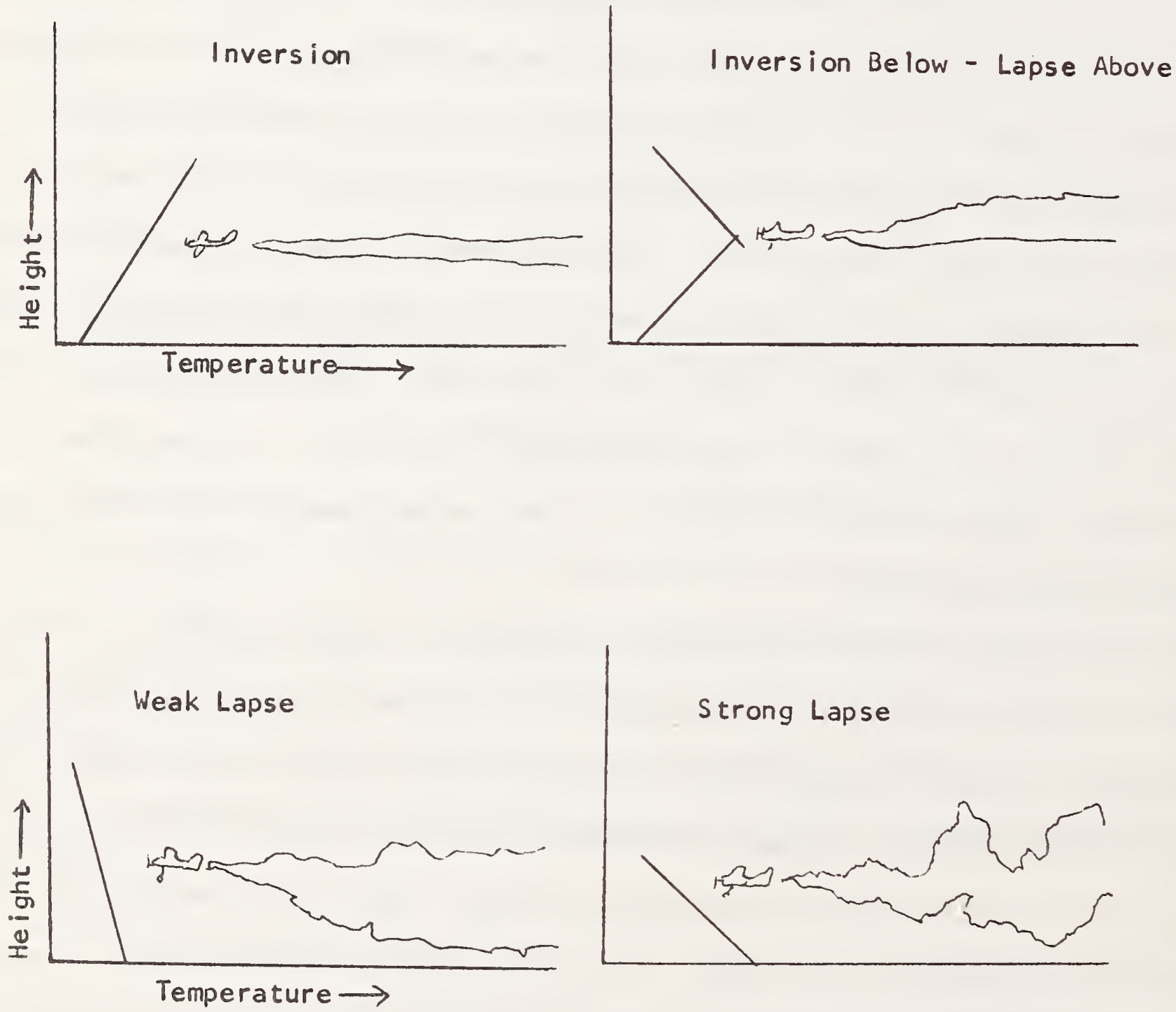
nearly always exists under these conditions. A definite wind direction is needed and spray particles should be large enough that they will fall through the inversion readily and inside the target area. Significant fallout of spray has been observed several miles from the point of release under certain topographic and air stability conditions (39). Care must be taken to assess the impact of inversion conditions that usually prevail under clear skies and little wind. The cooling effect of lower air causes settling to lower areas and may produce an almost undectable air movement generally downslope. This moving air will persist until sun warms the surface. Usually around 8 to 9 -a.m., the wind direction will shift to reflect generally rising air or air mass influence. This wind shift can be $180^{\circ}$. Some means of detection, such as a smoke column, should be used to determine the settling direction and when the wind direction is changing.

The influences of swath width are not easily separated from other factors. From previous discussions, however, it is apparent that wider swath widths with any given spray system will cause more drift, much as wider angle fan sprays cause finer droplet sizes. Effective swath widths are generally 100 to $150 \%$ of the wing or rotor lengths except with deliberate vortice effect or ultra low volume applications.

Tests by Akesson and Yates (25) to determine the effect of numbers of contiguous swaths shows increased drift with more swaths; hovever, the increase in drift was less than proportional to the number of swaths. Deposits of DDT from 80 swaths was only $25-50 \%$ greater than with 20 swaths.

The height of spray release is important in achieving good coverage and reducing the drift hazard. Best coverage in terms of uniform distribution and penetration is usually from eight to ten feet above the target. Streaking may result from lower levels, even from cone or fan nozzles, because of the propellor torque or rotor wash. Drift hazard with smaller drops may be increased directly proportional to the height, so a careful balance must be achieved in flying height to allow good dispersal without hazarcous drift. Of course, in applications to powerlines, much higher flight 
levels are used and extra care is needed to prevent drift.

The influence of wind speed and direction is important and increases with the height of the drop. The importance of air stability related to air movement was discussed above; nearly calm air can be more conducive to off-target drift hazards than with higher wind speeds. The distance and direction of off-target hazards always should be determined before application begins.

\section{DRIFT FROM GROUND APPLICATIONS}

Detailed studies as well as observations of commercial applications of sprays by ground equipment indicate that drift can be serious if proper procedures are not used. Maybank and Yoshida (28) in Canada measured the drift of 2,4-D at eight ounces a.e. per acre in sprays at five and ten gpa (650067 and 65015 Teejet, respectively) and at 25 and 40 psi with ground equipment. As expected there was noticeably less drift off the target with the larger nozzles and lower pressure; it was highest for the higher pressure (40 psi) and lower volume (5 gpa). Also, they showed that drift at different distances downwind both in the air and fallout increased as the area being sprayed was enlarged. Significantly the total amount of 2,4-D that would be deposited on a section of land downwind from a section sprayed with 2,4-D at eight ounces per acre in $5 \mathrm{gpa}$ at 40 psi was 35 ounces or $0.03 \%$ of the total applied. More was deposited closer to the sprayed field, but there were still measurable amounts in the air at the one mile downwind station. Of course, least deposits and airborne 2, 4-D were found at all distances with the larger nozzles and lower pressures.

Clearly, care must be taken to prevent drift from ground applications of herbicides, especially those that can affect plants at low exposure. Detailed analyses by Maybank and Yoshida (28) of spray deposits across a swath and resultant amounts of herbicide needed for good weed control indicate excessive rates are used to achieve desired results; variations in spray deposit across the swath even under apparently uniform conditions is the reason. Ashford (26) reports that, although lab and greenhouse data 
show increased efficacy as drop size is decreased, field results show that increasing numbers of drop sizes below about $100 \mu$ does not improve weed control appreciably. He believes the smaller droplets impact less readily on leaf surfaces. Evaporation of carrier before droplets reach the ground could also decrease benefits from the smaller drop sizes.

Bode et al. (29) studied relative effects of several nozzle types, system conditions and additives on drift with ground sprayer applications. They found that the Spraying Systems Co. low pressure (L.P.) flat fan and Delavan Mfg. Co. Rairidrop hol low cone nozzles gave much less drift than did the regular flat fan or the flooding (deflector) type. Lowering pressure at the nozzle with regular flat fan nozzles helped reduce drift also.

Higher volume rates generally result in less drift, but that is usually because larger orifices are used. Nozzles with higher flow rates at low pressure will result in least drift; volume rate per se can be a misleading criterion.

Bode et al. (29) found also that Nalco-Trol at 4 to 8 ounces of product per 100 gallons of spray reduced drift with low shear nozzles to about $1 / 10$ to $1 / 3$ that with no thickener. Ashford (26) did not report on drift from air emulsions (foam) systems, but we would expect more fines downwind than with water only systems as reported above in aircraft tests but in reduced amounts.

\section{EFFECT OF VARIOUS FACTORS ON HERBICIDE DRIFT}

The different factors affecting droplet size and resultant movement off the target (drift) are summarized in Table 5. These factors do not have equal importance, and priorities could change with each system and situation. The influence on drift hazard is indicated for the change in each factor.

This list is somewhat oversimplified and limited in scope; it should be used only to check the influence of each factor and help the operator make adjustments in the system or procedure as possible and needed for each situation. Several relationships apply on ly to certain ranges of conditions. The effect of "Wind Speed" 


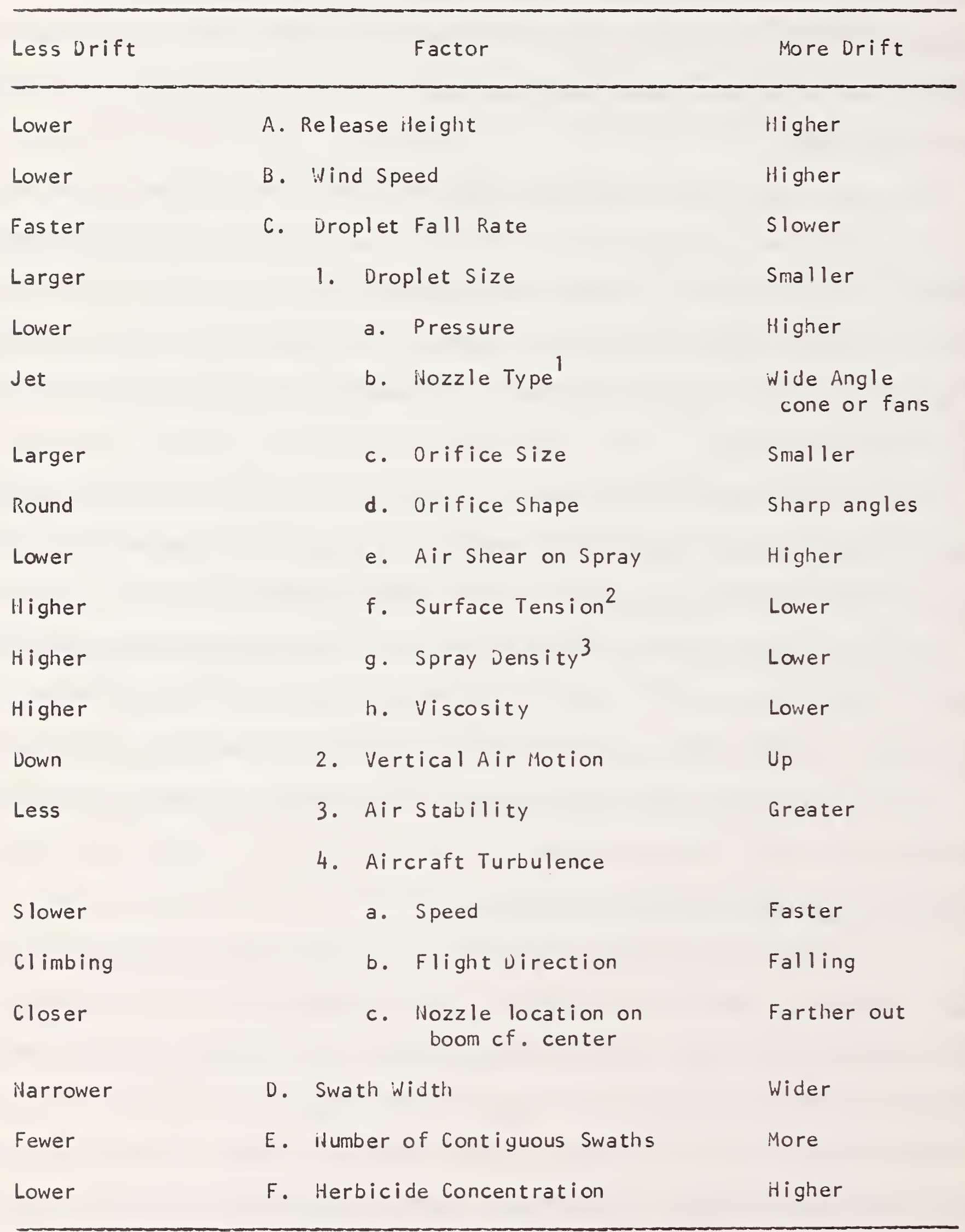

${ }^{1}$ Certain nozzle types can produce larger drops or narrower range. $2 \mathrm{Higher}$ oil or surfactant content reduces surface tension. $30 \mathrm{il}$ carriers are lighter (less dense) than water. 
here is only at slower speeds. Air movement is usually law under inversion conditions and when it increases from one to five or six mph, fallout will be greater. However, usually wind speeds above that will weaken or destroy the inversion, the mixing will help disperse fine droplets aloft and result in less drift. Air stability is usually the more important factor and increases in wind speed that did not destroy the inversion would result in increased fallout, but there would be less fallout at higher wind speeds than resulted in unstable air.

The effect of "Vertical Air Movement" on fallout must also be qualified. If the vertical component is the result of unstable air, this relationship would be reversed. It refers here to influences such as topographic or upwarded movement caused by wing or rotor tip vortices.

Pilots, as well as all operators of spray equipment, should be keenly aware that, any time a nozzle is over or near a field, orchard or garden, there is a chance of spray drops hitting these non-target areas. Great care should be exercised to prevent such accidental exposures. Turning or ferrying near or over susceptible plants or hazard areas should be avoided. Application of sprays with ground equipment will require careful attention to systems to prevent drift also. 
1. ZIMMERMAN, P. W., A. E. HITCHCOCK, Aild H. J. KIRKPATRICK, 1953. Methods for Determining Relative Volatility of Esters of 2,4-D and 0 ther Growth Regulants Based on Response of Tomato Plants, Weeds 2(3); 254-258.

2. JENSEN, D. J. AND E. D. SCHALL. 1966. Determination of Vapor Pressure of Some Phenoxyacetic Herbicides by Gas-Liquid Chromatography. J. of $\mathrm{Ag}$. and Food Chem. 14(2)

3. FLINT, G. W., J. J. ALEXANDER AND 0.P. FUNDERBURK. 1968. Vapor Pressure of Low Volatile Ester of 2,4-U. Wieed Sci. 16(4):541-544.

4. BEHRENS, R. 1957. Influence of Various Components on the Effectiveness of 2,4,5-T Sprays. Weeds $5(3): 183-196$

5. MCKINLAY, K.S., S. A. GRANDT, P. MORSE AND R. ASHFORD. 1972. Droplet Size and Phytotoxicity of Herbicides. Weed Sci. 20(5): 450-452.

6. WIT, H. M. 1972. Principles of Drift of Pesticide Sprays. Proc. Symposium Pesticides, Pest Control and Safety on Forest and Range Lands.

7. KLINGMAN, GLENN. 1961. Weed Control As a Science. John wiley and Sons, p. 97.

8. YATES, W. E. AND in. B. AKESSON. 1966. Characteristics of Drift Deposits Resulting from Pesticide Applications with Agricultural Aircraft.

Proc. 3rd. Intl. Agri, Aviation Congress, ivetherlands.

9. POTTS, S.F. 1946. Particle Size of Insecticide and Its Relation to Application Distribution and Deposit. J. Econ. Entom. $39(6)$.

10. SEYMOUR, K. G. 1967. Unpublished data, The Dow Chemical Company, Midland, Michigan

11. BYRD, B. D. 1960. Unpublished data, Spray Drift Control, The Dow Chemical Company, Midland, Michigan.

12. COURSHEE, R. J. 1959. Investigations on Spray Drift, Part 11, Occurrence of Drift. J.Agri. Engin. Res., 4(2).

13. SEYMOUR, K. G. AND B. C. BYRD. 1964. Wind Tunnel Evaluation of Spray Drift Potential. Proc. Am. Soc. Agri. Engineers.

14. TATE, R. W. AND L. F. JANSSEN. 1965. Uroplet Size Data for Agricultural Spray Nozzles, Paper No. 65-155, Proc. Am. Soc. Agri. Engineers.

15. COUTS, H. H. AND W. E. YATES. 1965. Analysis of Spray Droplet Distribution from Agricultural Aircraft. Paper Ho. 65-157, Proc. Am. Soc. Agri. Engineers

16. TATE, R. W. AND L. F. JANSSEN. 1966. Droplet Size Data for Agricul tural Spray Nozzles. Trans. Am. Soc. Agri. Engineers, 9 (3)

17. ISLER, D. A. AND J. B. CARLTON. 1964. The Effect of Mechanical Factors on Atomization of 0 il Base Aerial Sprays. Proc. Am. Soc. Agri.

Engineers, Paper No. 64-608. 
18. GRATKOWSKI, H. J. AivD R. E. STEW'ART. 1973. Aerial Spray Adjuvants for Herbicidal Drift Control. U.S.D.A. Forest Service Tech. Rpt. PNW-3.

19. LANING, E. R. AND T. W. HOLMSEN. 1969. Minimizing Spray Drift of Herbicides. Industrial Vegetation Management 1(2):2-5.

20. BYRD, B. C. AND K. G. SEYMOUR. 1964. Wind Tunnel Studies of Thickened and Particulate Sprays. Paper No. 64-609D, Proc. Am. Soc. Agri. Engineers.

21. YATES, W. E., N. B. AKESSON AND D. E. BAYER. 1974. Effects of Spray Adjuvants on Drift Hazards. Paper Ho. 74-1008, Proc. Am. Soc. Agri. Engineers.

22. MOORE, A. D. 1967. Aircraft in Forest Insect Control. Proc. Aerial Applicators' Short Course.

23. YATES, W. E., N. B. AKESSON AND R. BRAZELTON. 1967. Bas ic Factors Related to Distribution Patterns from Agricultural Aircraft. Proc. Western Reg. Pesticide Chem. Applicator's Short Course, II: C1-31.

24. WARREN, L. E. 1973. Pattern Studies with Jet ilozzles on a Helicopter. Unpublished data, The Dow Chemical Company, Davis, Calif.

25. AKESSON, N. B. AND W. E. YATES. 1964. Problems Relating to Application of Agricultural Chemicals and Resulting Drift Residues. Ann. Rev. Entom., 9.

26. ASHFORD, R. 1974. Herbicide Efficacy and Drop Size. Proc., Canadian Weed Committee, 28th Annual Meeting, pp. 32-33.

27. GROVER, R. 1974. Reducing Droplet Drift From Existing Farm Sprayers. Proc. Can. Weed Comm., 28th Ann. Mtg., pp. 18-19.

28. MAYBANK, J. AND K. YOSHIDA. 1973. Droplet Deposition and Drift from Herbicide Sprays - Analysis of the 1973 Ground-Rig Trials. Saskatchewan (Canada) Res. Council, Physics Div., pp. 73-76.

29. BODE, L. E., B. J. BUTLER AND C. E. GOERING. 1975. Effect of Spray Thickener, Nozzle Type and Nozzle Pressure on Spray Drift and Recovery. Paper No. 75-1065, Proc. Am. Soc. Agri. Engineers.

30. YATES, W. E. 1975. Drift Reduction Techniques for Aerial Spray Applications. Proc. 27th Ann. 111. Custom Spray School.

31. WILCE, S. E., N. B. AKESSON, W. E. YATES, P. CHRISTENSEN, R. E. COWDEN, D. C. HUDSON AND G. I. WEIGHT. 1974. Drop Size Control and Aircraft Spray Equipment. Agri. Aviation, Intl. Aviation Ctr., 16(1):7-16.

32. AKESSON, N. B., R. FOSSE. 1960. Invert Emulsions Reduce Unwanted Drift. Agrichemical West, $31(6)$.

33. SPRAYING SYSTEMS CO. 1967. Graph - Particle Size vs. Volume Percentage for $15^{\circ}$ Flat Spray Nozzles, Drwg. $12135-7$. 
34. IBID. 1966. Graph - Spray Particle Size vs. Pressure, $15^{\circ} \mathrm{Flat} \mathrm{Spray}$ Nozzles, Drwg. 11825-r..

35. WARREN, L. W., W. E. YATES AND S. R. RADOSEVICH. R1975. Control of Drift from Helicopter Applications of TORDON 101 Mixture and Triclopyr with Nalco-Trol. Unpublished data, the Dow Chemical Company and University of Cal ifornia, Davis, Cal ifornia.

36. FEDERAL REGISTER。 1974. No. 121.1225. Adjuvants for Pesticide Use Dilutions (Sodium acrylate and acrylamide co-polymer (Nalco-Trol) Vol. 39, No. 241, December 13, 1974.

37. BOUSE, L. F. AND R. E. LEERSKOV. 1973. Drift Comparisons of Low Expansion Foams and Conventional Sprays. Heed Sci. 21 (5):405-408.

38. THE R. L. WILSON COMPANY. -.--. Wilsco Foamspray Data Sheet.

39. LAUCKE, J.E. 1974. Application of Paraquat and Diquat by Air. Chevron Chemical Co., p. 13.

40. HAMAKER, J.W. 1975. Vapor Pressures of 2,4-D Acid and its Esters. (Private communication). The Dow Chemical Company, Walnut Creek, Cal ifornia. 
In 1962 vegetation control systems using herbicides were introduced by the military into the Southeast Asia Conflict. Their use was to remove dense vegetation along highways, canals, I ines of communication, and around base perimeter camps; thereby reducing enemy ambush. The herbicide formulation of choice was an equal mixture of the n-butyl esters of $2,4-D$ and $2,4,5-T$. This formulation was labelled Orange because of the orange band around the centers of the 55-gallon drums in which it was transported.

Although severe criticism of the defoliation program was voiced as early as 1964, it was five years later before the program (Operation Ranch Hand) was suspended by the Department of Defense. Initial criticism was directed at Orange as a chemical warfare agent used against crops and the environment of South Vietnam. However, the termination of the program was not based on the above criticism but rather on reports by South Vietnamese newspapers of an increased occurrence of birth defects during June and July 1969 from areas defoliated with Orange Herbicide. These reports elicited far-reaching reactions from governmental agencies, segments of the scientific community, lay groups concerned with environmental problems, and from the commun $i$ cation media. Government sponsored panels of experts, special commissions established by scientific organizations, hearings before subcommittees of the $U$. S. Congress, and Conferences attended by representatives from industry, government, and universities examined available data and were not able to provide a generally acceptable answer to the central question of whether $2,4,5-T$ as produced and used constituted a risk for human pregnancy.

In mid-October 1969, a report was released to the press of the findings of a study by Bionetics Research Laboratories, Litton Industries Incorporated. The report documented the presence of defective offsprings from mice and rats treated during Presented by Captain Alvin L. Young, Ph.D. Associate Professor of Physiology, Department of Chemistry and Physiology, United States Air Force Academy, Colorado 
early pregnancy with large doses of $2,4,5-T$. It was subsequently announced on october 29. 1969, that a series of coordinated actions were being taken by several governmental agencies to restrict the use of the herbicide 2,4,5-T. Additional animal experiments performed early in 1970 confirmed that pregnant mice did deliver some malformed offspring. The question then was one of whether or to what extent, such animal date could be extrapolated to man. On April 14, 1970, the Secretary of Health, Education and Welfare (HEW) advised the Secretary of Agriculture that: "In spite of these uncertainties, the Surgeon General feels that a prudent course of action must be based on the decision that exposure to this herbicide may present an imminent hazard to women of child-bearing age." Accordingly, on the following day, the Secretaries of Agriculture, HEW, and Interior jointly announced the suspension of 2,4,5-T for "all uses around the home, recreation areas, and similar sites" and "in all uses on crops intended for human consumption." Immediately thereafter, the Department of Defense suspended the use of Orange Herbicide in South Vietnam.

The suspension of the use of Orange Herbicide left the Department of Defense with 1.5 million gallons in Vietnam and 860,000 gallons at the Naval Construction Battalion Center, Gulfport, Mississippi. In September 1971, the Secretary of Defense directed the Joint Chiefs of Staff to dispose of the surplus inventories of herbicide in both the Continental United States and Vietnam. The Air Force was assigned the responsibility of finding a disposal method(s) that was (were) ecologically safe and economically feasible. In April 1972, the 1.5 million gallons of herbicide in Vietnam was placed in 55-gallon drums and transported to Johnston Island, Pacific Ocean. The total Orange Herbicide inventory was $2.3 \mathrm{mill}$ ion gallons stored in approximately 40,000 55-gallon drums. Thus, not only is there herbicide to be disposed but also the drums.

The initial method proposed for disposal was incineration at a comercial facility in the United States. The details of this proposed course of action were documented in 
a draft environmental statement which was filed with the Council on Environmental Quality and the Public in January 1972. The draft statement discussed the studies that were being accomplished, but not completed when the statement was filed. Based on the fact that studies were still in progress and the interest evidenced in comments received on the draft statement, the Air Force decided to conduct additional studies on incineration as well as additional investigations of alternative disposal methods. In April 1972, the Air Force Logistics Command (AFLC) began an indepth investigation into the feasibility of use, incineration, soil biodegradation, factionation, chlorinolysis and reprocessing as major disposal options. Data to be collected on each method included the parameters of time, cost, and effectiveness of the disposal process. In addition, the physical, biological, managerial and social-political factors for potential sites of disposal were to be assessed. Reports of progress and/or problems encountered were periodically presented to an Ad hoc Committee on the Disposal of Herbicide Orange of the Air Force Scientific Advisory Board. Other disposal options reviewed and discussed with the Ad hoc committee were return of the herbicide to the manufacturer, deep well disposal, burial in an underground nuclear cavity, $s$ sludge burial, microbial reduction, and no disposal action. The last option was to be selected only if the other options were not ecologically acceptable, technology not sufficiently developed for their employment, if excessive capital investment was required, if unacceptable time delay was imminant, or if the socio-political opposition prevented any course of action. The option of "no action" would mean that Orange would be placed into seal storage tanks for permanent storage at both Johnston Island, and Gulfport, Mississippi.

In the formulation of an environmental impact statement on the disposal of Orange the following description of action for each option was prepared.

1. Use

Orange herbicide is not an Environmental Protection Agency (EPA) registered pesticide and cannot be domestically used or sold. The Orange Herbicide stock to be 
disposed represents a resource of considerable monetary value (a recent estimate is $\$ 80$ - 100 million). Orange Herbicide has a potential use on Federal lands as well as on privately owned lands; however, any use would require registration. The prudent disposition of Orange Herbicide for use on privately owned or governmentally owned lands may have a tremendous impact on increasing the availability of certain natural resources, e.g., rangelands and forests.

Undesirable weed and brush species are widespread in every region of the United States. Their combined impact on rangelands and production of commercial timber is enormous. Approximately half of the total land area of the United States is used $f$ for pasture and grazing purposes, and weeds and brush are a problem on nearly all these forage lands. Economic losses from weeds on forage lands are virtually incalculable and include low yield of forage and animal products per unit area, reduced livestock gains, and livestock poisoning. Although herbaceous weeds are found on all rangelands in the United States and result in forage losses, brush is the primary problem. Various brush species dominate an estimated $320 \mathrm{million}$ acres of rangelands. More than $80 \%$ of $107 \mathrm{million}$ acres of grazing land in Texas alone is infested to some extent with brush. Once established, wwood plants such as mesquite (Prosopis spp.), juniper (Juniperus spp.), oak (Quercus spp.), and sagebrush (Artemisia spp.) cannot be eliminated by good grazing practices alone. Measures must be taken to convert brush dominated rangeland to more productive types of vegetation. Brush control and striking improvements in the grazing capacity of rangeland may be obtained most economically by low-rate and low-volume applications of phenoxy herbicides.

Commercial forest land in the United States is estimated at 509 million acres. Although much of this land is not under any form of planned management for production of forest products, management for an increased productivity will soon become essential to meet the needs of the United States population. It is estimated that the 
total area of forest lands supporting important amounts of undesirable vegetation is approximately 300 million acres, or a land area potentiall commercial timberland equal to roughly the combined areas of Texas, California, and Washington. There are some 4.7 million acres of commercial forest land in western Oregon and Washington on which the land is occupied by vegetation whose presence precludes reestablishment of conifers. Much of the area is in the highest productivity class for growth of forest: products.

Concepts of selective brush control have been developed for reforestation with the aid of commercial formulations of $2,4-0$ and $2,4,5-T$. There are presently some 100,000 acres being treated each year with various formulations of these materials, all as the low-volatile esters. Success has been good, especially in operations on the slower-growing brush species.

Thus, the purpose for using herbicide Orange on rangelands and reforestation would be to reduce the amount of undesirable vegetation that dominates in selected regions of the United States because of past disturbances and improper grazing and/ or timber practices. With the use of herbicide Orange, a more diversified and desirable variety of plant species would become established. This in turn would have a substantial impact on increasing productivity of these regions.

The environmental impact of using herbicide Orange for chemical brush control will vary from region to region and whether it is for range or forest use. However, regardless of the region of use, or for rangeland or reforestation, critical assessments of effects on vegetation, wildlife, domestic livestock, soil microorganism, aquatic life, rangeland or forest waters, and man must be evaluated.

\section{RETURN TO MANUFACTURERS}

In March 1972, seven manufacturers of herbicide Orange were contacted regarding the possibility of chemically reprocessing Orange Herbicide whereby all impurities, including dioxin, would be estracted or destroyed. Results from all manufacturers were essentially the same; i.e., they did not feel that they were 
capable of reprocessing the product without extensive investment in equipment and/or development of new processes. Lead time for this type of action would require in excess of 18 months before large scale reprocessing could begin. As a result of EPA's action on June 24, 1974 to cancel the hearings on the possible further restriction of 2,4,5-T, the manufacturers were aga in contacted (August 1974) via letter to determine if their position may have changed. Manufacturers again indicated that they did not want to reprocess Orange.

\section{DEEP (INJECTION) WELL DISPOSAL}

This process would involve injection of the herbicide into a deep subsurface formation. The well hole down into the formation would be lined with casing which has been cemented into place to prevent fluids from rising to the surface outside the casing to a permeable geologic formation. The herbicide drums would be emptied into tanks or vats on the surface where the Orange Herbicide would be diluted and then pumped down the tubing to the permeable formation. The packer tool prevents fluid from returning to the surface inside the casing and impermeable upper and lower formations adjacent to the permeable formation restrict verticle movement. This process has not been approved by state agencies, or the EPA, as deep well injection is not considered environmentally safe or desirable disposal method for waste materials. The policy is to oppose all storage or disposal of wastes in deep wells without strict controls and a clear demonstration that such disposal will not: a) interfere with present or potential use of subsurface water supplies, b) contaminate interconnected surface waters, or c) otherwise damage the environment. Little concrete information in available on what degradation of the Orange would occur at the depths, temperatures, and pressures encountered in deep wells. This coupled with the possibility of subsurface disturbances at a later date which might allow Orange to migrate into formations leading to water supplies or other valuable formations, has prevented any of the firms interested in disposing of Orange in deep wells from obtaining state or Federal permits. 


\section{BURIAL II UNDERGROUND HUCLEAR TEST CAVITIES}

The Atomic Energy Cormission was contacted regarding the possibility of disposing of the Orange by burying it in an earth cavity formed during underground nuclear testing. They advised that a major research, development, and experimentation effort would be required to prove the practicality of this alternative. In view of the time required for this effort, it is not considered a feasible alternative.

\section{SLUDGE BURIAL}

This technique offered definite promise, but there was a lack of interest and qualified industries to undertake the necessary preliminary investigations. This process involves one concept of destroying the Orange through bacterial action. The proposal envisioned constructing trenches in geologically suited formations on isolated government land. The type of formations picked for the trenches would preclude vertical and lateral movement of the orange and would then be surrounded by secondary sewage plant sludge, which would provide a growth medium for the bacteria. The tops of the drums would then be mounded with dirt fill and aggragate. Depending upon the type of bacteria selected to decompose the Orange, vents might be required. This process is not considered acceptable because of the time to completely destroy the herbicide is quite lengthy, possibly as long as 10 to 25 years, and because a system of monitoring would be required throughout this time period. The earth covering would require maintenance and additional time might also be required to develop a strain of bacteria that would tolerate high concentrations of Orange.

\section{MICROBIAL REDUCTION}

This process involves the biological degradation of the herbicide through fermentation. It requires the development of a microorgan ism to "feed" on the herbicide. From the literature, it seems apparent that microorganisms have developed unbelievatle capabilities for handling organic compounds. However, two factors severely complicate the biological degradation of this refractive material: 1) its insolubility in water and 2) its chemical structure (specifically the number 
and position of chlorine atoms attached to the aromatic ring). Many investigators have showed that $2,4-D$ is rapidly decomposed in the soils and that high concentrations have no depreciable effect on the soil population of bacteria, fungi, and actinomycetes. The presistence of $2,4,5-T$ is usually two or three times longer than 2, 4-D and very few microorganisms have been identified as having the ability to break down the 2,4,5-T molecules. Data are available that indicate that mixtures of 2,4,5-T are more rapidly degraded than are single compounds. Very little work has been done on the microbial degradation of TCDD; however, initial data indicate that it is degradable, but with an estimated half life of one year (as a single compound).

The environmental impact of a microbial reducation method is dependent upon the fate of TCDD in a biological treatment facility. It must be established that no TCDD is remaining in the effluent, or a problem of enormous consequences can occur. Thus far no data are available on the fate of TCDD in a biological reduction system. All other aspects of such an alternative can be controlled and minimized to an acceptable level. Monitoring methodology and a failsafe system would be required. Until more data are developed the particular environmental aspects cannot be evaluated. More specific information concerning the process, size of facility, land acreage required, and effluent parameters are needed.

\section{FRACTIONATION}

Fractionation is the process of converting 0 range into its acid ingredients by means of distillation. This would separate the normal butyl esters of $2,4-0$ and 2,4,5-T and its contaminant TCDD. the 2,4-D would be reformulated for commercial use. TCDD would then be destroyed by chemical, biological or incineration techniques. Actual distillation efficiencies theoretically could approach $90-95 \%$. One investigator stated that any TCDD residue could be destroyed by splitcing the ether bonds of the molecule. In the process of fractionation, the dioxin would be isolated or destroyed. A small scale study was funded, but the results were inconclusive. 
Fractionation is not acceptable because: a) the fate of the dioxin has not been demonstrated, b) in the process, 3\% of the 0range processed could not be accounted for, c) standards to control and monitor vapor and fluid emmissions into the environment have not been identified.

\section{SOIL BIODEGRADATION}

Soil biodegradation is a soil incorporation technique based on the premise that high concentrations of the Orange Herbicide and the contaminant TCDD will be degraded to innocuous products by the combined action of soil microorganisms and soil chemical hydrolysis. The rationale for soil incorporation of herbicide as an ecologically-safe disposal method comes from pertinent laboratory and field studies.

It seems apparent from laboratory studies that microorganisms have developed extensive capabilities for handling organic compounds. Moreover, most organisms seem to have a latent ability for decomposition of halogenated hydrocarbons. However, the amount of active herbicide applied to soil may diminish by means other than biological decomposition; e.g., chemical degradation, absorption, volatilization, leaching, and photodecomposition.

Until recently there was very 1 ittle information concerning the breakdown of $2,4-D$ or 2,4,5-T in a soil incorporation site. However, field experiments on the use of soil incorporation as a method of disposing of massive quantities (approximately $1-1 / 4 \mathrm{mil}$ I ion gallons) of 2, 4-D and waste by-products has been carried on in eastern 0 regon. A trenching technique was employed to simulate subsurface injection. A concentration of $500 \mathrm{lb} / \mathrm{A} 2,4-\mathrm{D}$ (plus waste) was placed at a depth of 10 inches (5-inch bands on twofoot centers). With this placement the actual concentration of herbicide within these bands was approximately $1250 \mathrm{ppm}$. Samples taken between trenches and in soil profile segments from the surface down through the point of application indicated minimal vertical and horizontal movement of the herbicide (or phenolic waste) from the site of initial deposition. Results from this experiment indicated little differences in rates of degradation in the trenched plots or a surface application of $5001 \mathrm{~b} / \mathrm{A}: 95 \%$ 
degradation in 540 days.

Our project group at the United States Air Force Academy has studied the persistence and movement of herbicide Orange and TCDD following soil incorporation at rates of $1,000,2,000$, and 4,000 pounds active ingredient $2,4-D$ and $2,4,5-T / a c r e ~(1 b$ ai/A) in a remote site in western Utah. The precent loss of herbicide over a 330 day sampling period was $78.2 \%, 75.2 \%$ and $60.8 \%$ for the $1,000,2,000$ and 4,000 $1 \mathrm{~b}$ ai/A plots, respectively. The calculated half-life or herbicide Orange in alkaline (pH=8.1) desert soils was approximately 150 days at these massive rates. Data on soil penetration indicated that less than $3.7 \%$ of the herbicide was found at depths greater than 18 inches 282 days after soil incorporation of 4,000 lb ai/z. Preliminary data based on levels of TCDD in the formulation $(3.7 \mathrm{ppm})$ and those encountered in the soil profile 265 days following soil incorporation suggested that under these environmental conditions that half-life of TCDD was 88 days. Our USAF Academy team also established biodegradation plots in Garden City, Kansas and Elgin AFB, Florida. Data from these incorporation studies are in agreement with the Utah plots: degradation of 2,4-D, 2,4,5-T and TCDD when applied at massive rates, rapidly occurs and movement of the herbicide in fact is minimal.

It is important that the criteria for selection of a site for soil biodegradation include certain physical, biological, and managerial factors.

(1) Physical Factors: From the standpoint of just physical consideration, the soil incorporation technique provides an array of alternatives as to the selection of site. In general:

(a) A minimum of 2,000 acres must be available.

(b) The site must be remote. It cannot be adjacent to land currently in agronomic production.

(c) The land must have a low-use potential, i.e., it should be marginal land. Moreover, the land should not be considered land that will be significantly productive in the foreseeable future.

(d) Vater resources must be sufficiently far away so as not to be contaminated.

(e) The topography of the land must be relatively flat with a uniform surface.

(f) The texture of the soil should be sandy-loam or silty-loam with a pil of approximately 8.0 . 
(g) The area should not be characterized by rock outcrops or areas of marked deflation or dunes. The area should also have minimal surface erosion.

(h) Data should be available on subsurface geology and hydrology.

(2) Biologicai Factors: The vegetation that characterizes the particular site must be uniform with a ground cover of at least 10 - 15\%. Such a plant community will provide the organic matter and microclimate that supports the growth and maintenance of microflora (e.g., fungi and bacteria). Ideally, the vegetation should be low-growing shrubs, forbs and grasses to facilitate the incorporation equipment.

(3) Management Factors: The management factors that will influence the selection of the site are:

(a) The requirement for established all weather roadbeds to and within the disposal site.

(b) The distance to the disposal site from an off-loading station (e.g., rail to truck).

(c) The requirement for security of the disposal site.

(d) Availability of personnel facilities.

(e) Adequate storage space at the disposal site.

A subsurface injection system would be used to incorporate the herbicide into the soil at a depth of six to ten inches. The injection would be done by using a conventional agricultural subsoiler, drawn by a heavy industrial tractor. The subsoiler would consist of a verticle blade on which a chisel, or foot, is mounted at an angle of approximately $15^{\circ}$ from horizontal. A piece of metal tubing will be at tached to the blade (and terminating at the base of the chisel) in such a manner that a piece of hose from the injection pump could be inserted to permit disposition of the herbicide immediately behind the chisel. The equipment, with eight injectors (shanks), should be cal ibrated to apply $4000 \mathrm{lb} / \mathrm{A}$ of 0 range. The eight shanks should be on 20-inch centers. During the process of application the overlying vegetative structures will be damaged. To prevent the loss of soil moisture and to reseal the soil (thus minimizing volatility and damage from wind) a soil compactor (cultipacker) will be required and a drought resistant, salt tolerant grass will be planted. 
The environmental impact of soil biodegradation would be expressed in two major areas; the most significant of which is the denial of a $1,000-2,000$ acre tract of land for reclamation or recreation use for a three to five year period during biodegradation. The proposed site would require continuous monitoring during the lifetime of the project. Also occurring will be damage and/or kill of the overlying vegetative structure in the immediate disposal area, drastic alteration of the soil structure, and disturbance and/or temporary destruction of local ecosystems. Adherence to the above site criteria and incorporation method will optimize the soil biodegradation procedure and minimize adverse environmental impact.

\section{CHLORINOLYSIS}

From the theoretical engineering point of view, chlorinolysis offers an efficient, controlled, and safe method for disposal of the herbicide, as well as other hydrocarbon formulations. Chlorinolysis is a process that breaks down the molecule and adds a chlorine molecule to produce carbon tetrachloride, phosgene, and anhydrous hydrogen chloride, all of which have established comercial value.

Chlorinolys is as a means to dispose of Orange llerbicide was evaluated over a period of almost two years. In July of 1972, discussions and correspondence with the Environmental Protection Agency (EPA) comitted the Air Force to pursue the testing and research program necessary to determine the feasibility of converting Orange to salable products by chlorinolysis. In September 1972, a Memorandum of Agreement between the EPA and the Air Force was initiated. The objective of the agreement was the development of a laboratory program to evaluate the practicality of the application of chlorinolysis for the disposal of orange. The investigation was also to determine the extent of destruction of the impurity dioxin. The information and data obtained in this research was to be utilized by the Air Force to determine whether the proposed concept could be applied and used to dispose of Orange and by the Environmental Protection Agency to determine if it could contribute toward solving the disposal probleris of the petrochemical industry. It was 
agreed that the EPA would manage the research and provide a report containing all data collected, together with conclusions and recommendations. The Air Force agreed to fund the effort in the amount of $\$ 35,000$. An additional $\$ 10,000$ was provided for analysis of dioxin. Three drums of Orange containging 14 ppm dioxin (analysis by Dow Chemical Company) were provided by the Air Force.

The EPA report, "Study of Feasibility of Herbicide Orange Chlorinolysis" (EPA600/2-74-006, July 1974), covering only the work of Diamond Shamrock Company was delivered on October 2, 1974. The report covered the results of bench scale tests and concluded, based on these bench scale tests, that chlorinolysis under the proper conditions effectively converts Orange Herbicide and its TCDD contaminant to carbon tetrachloride, carbonyl chloride and hydrogen chloride. Destruction of the TCDD was complete, and preliminary toxicology tests of the recovered carbon tetrachloride on rabbits showed no evidence of TCDD contamination. The report also contained cost estimates which included credit for the sale of chemicals from 25 ton/day plant. The cost in the worst case was shown to be $\$ 11 \mathrm{mill}$ ion and in the best $\$ 4$ million.

Owing to the uncertainties associated with developing this technique to a full scale plant capable of processing 2.3 million gallons of Orange in a timely and economical manner. Partial or total chlorinolysis was not selected as the method of disposal even though it is satisfactory from an environmental point of view.

10. INCINERATION AT SEA

One of the most viable options for the destruction of Orange Herbicide is via incineration on a ship at sea. Since September 1972, a ship the "Volcanus" (registered in Rotterdam, Netherlands) has been equipped to carry certain hazardous liquid chemical cargoes from northern European ports and approved by participating countries to incinerate the waste cargo in prescribed areas of the iNorth Sea. Additionally, U. S. Companies have suggested shipboard incineration and have indicated a willingness to investigate it.

The ship is a double hulled and double bottorn tanker with an overall length of 
331.4 feet, a beam of 47.2 feet and a draft of 22.9 feet. Her construction complies with the latest Inter-Governmental Maritime Consultative Organization (IMCO) regulations of bulk carriage of dangerous chemicals at sea. Because of her size, the vessel is able to operate and continuously man the incineration process. Two diesel engines drive the single propeller to give service cruising speeds of 10 to 13 knots.

The vessle's cargo tank capacity of 3,503 cubic meters (CBM) ( 925,493 gallons) is divided into 15 cargo tanks ranging in volume from $115 \mathrm{cbm}$ to $574 \mathrm{cbm}$. ilone of these tanks are in contact with the vessel's hull and/or bottom. The engine room is separated from the cargo tanks by double bulkheads, the pump room and generator room being situated in between.

The incineration system consists of two combustion chambers installed right aft of the upper deck. Each of the bricklined incinerators has a maximum outer diameter of 5.50 meters $(\mathrm{m})$, and inside diameter of $4.80 \mathrm{~m}$ and a total height, including the stack, of $10.45 \mathrm{~m}$. The volume of each conbustion chamber is calculated to be 87.9 $\mathrm{cmb}$. Each chamber has three burners with rotating cup fuel injection systems which provide vortex turbulence and distribution of fuel feed throughout the whole chamber. Incineration could be conducted in a designated area 50 to 60 miles clear of normal shipping lanes and on the open tropical sea downwind of Johnston Island. Gas or diesel oil would be used to bring the chambers to the required combustion temperature, normally $1400^{\circ} \mathrm{C}\left(2552^{\circ} \mathrm{F}\right)$; the maximum operating temperature is reported as $1650^{\circ} \mathrm{C}$. Only when the required temperature is reached would the feed pumps allow waste to enter the combustion chambers. Waste feed flow and air would be carefully controlled to insure complete combustion. Once the required temperature was obtained, the chambers would be fed solely by the undiluted Orange. The Orange could be pumped to each of two chambers at a rate of 10 to 12 toms per hour for a total daily pump rate of about 576 tons. Therefore, about 22 to 26 days of continuous incineration 
would be required to burn the entire 0range stock ( 2.3 million gallons). The vessel's capacity of about 925,000 gallons of Orange would require three voyages; 925,00 gallons of Orange would be burned during each of the first two voyages, and the remaining 380,00 gallons of Orange plus any solvents used in drum cleaning would be burned during the third voyage.

The data accumulated, together with theoretical considerations and applied thermochemistry, clearly indicate that the production of incomplete combustion products can be minimized to insignificant levels. Destruction, efficiencies of $99.9 \%$ or better appear feasible for this incinerator project. This would result in a total discharge of 0.05 pounds or less of TCDD via the exhaust streams over the duration of the project. (The average concentration of TCDD in the herbicide is about $2 \mathrm{mg} / \mathrm{kg}$ and the total amount of TCDD in the entire Orange stock is approximately 50 pounds). The commercial incinerator test program indicates that if any TCDD were present in the exhaust stream, it analytically nondetectable. Incineration would convert the Orange herbicide to its combustion products of carbon dioxide, hydrogen chloride, and water which will be released to the atmosphere. In addition, a relatively small amount of elemental carbon and carbon monoxide would be generated in the incineration process and discharged to the atmosphere. With proper concern for the environment in which such incineration would take place, incineration is an environmentally safe method of disposal of Orange Herbicide.

Ecological monitoring is neither required nor feasible for the following reasons: a) the ship will complete the project within a month and always be moving and operating over a large area of the open tropical sea; and b) the predicted impact will be very minimal and transient for this incineration option. A dispersion zone model utilizing "worst case" analyses techniques was used to estimate mass concentrations of unburned Orange and Hydrogen chloride in the air and water environment in the vicinity of the discharge, and a meteoro!ogical model was applied to predict the atmospheric concentration of unburned Orange and hydrogen chloride at sea level downwind of the discharge 
location. Predicted results from these models revealed that there would be no significant environmental impact upon either the air or ocean environment.

11. INCINERATION ON JOHNSTON ISLAND

If incineration at sea is not approved by EPA (e.g., if a permit for incineration at sea were not approved) than an alternate incineration option would be the construction of an incinerator facility on Johnston Island. Incineration on Johnston Island would require a higher efficiency owing to the ecology of the Atoll. (A complete ecological survey was conducted of Johnston Is land by the Smithsonian Institution in order to document the areas of concern). The facility on Johnston Island would probably be designed to incinerate about 206 drums of herbicide per day. At this rate, approximately 200 burn days would be required to incinerate all 2.3 million gallons of the Orange stock.

Thermal decomposition research using differential thermal analys is was conducted to determine the temperatures required for complete combustion of Orange Herbicide and a test program was conducted in a commercial incinerator to document the feasibility of destroying undiluted Orange Herbicide by means of combustion. Particular emphasis was placed on the ability to destroy the low quantity of TCDD (low miligram per kilogram concentration, $\mathrm{mg} / \mathrm{kg}$ ) present in the herbicide. Extensive sampling, utilizing time-weighted and concentration techniques, was conducted to evaluate the unscrubbed combustion gases, the scrubbing liquid used to cool and scrub the combustion gases, scrubbed effluent gasses, and any solid residues deposited in the system. Program objectives were outlined to determine, among other things, engineering data relative to controlling and monitoring the incineration process, the composition of the combustion products, and the toxicity of discharged scrubber water to several aquatic organisms.

For a system operating at combustion chamber temperatures of $2400-2800^{\circ} \mathrm{F}$; dwell time equal to or greater than 0.14 seconds; fuel to air mass ratio of about 0.1 ; and 
excess air greater than $30 \%$, it can be stated that: a) combustion gas and scrubbed effluent gases are free to undetectable levels. ( $\left(n 0.20 \times 10^{-3} \mu \mathrm{g} / 1\right.$ for each compound) of herbicide esters, acids, and TCDD; b) about $10 \%$ of the carbon dioxide and greater than $99.9 \%$ of both the hydrogen chloride and carbon particulates are removed from the combustion gases via an alkaline scrubber; c) combustion pyrolyzates are unchlorinated hydrocarbons whose total concentrations average less than $0.50 \mu g / l$; d al kali scrubbing removes a small fraction of the pyrolyzates from the combustion gases, and with gaseous condensation in presence of chlorine, converts some of the pyrolyzates into chlorinated hydrolyzates; e) total unchlorinated pyrolyzates average less than $13.0 \mu \mathrm{g} / 1$ and total chlorinated hydrolyzates average less than $3.0 \mu \mathrm{g} / \mathrm{l}$ in the spent scrubber water; f) carbon particulates contain no detectable levels of any type of hydrocarbon and the mass of these particulates was less than $0.5 \%$ of the carbon in the herbicide; g) carbon dioxide, carbon monoxide, and heat of combustion gases are not environmentally significant; and $h$ ) dispersions of scrubbed effluent gases into the atmosphere have no effect on tomato plant bioassays and attest to the lack of phytotoxicity of the gases.

\section{INCINERATION IN THE CONTINENTAL UNITED STATES (CONUS) ROCKY MOUINTAIN} ARSENAL, COLORADO

An incineration system has been constructed, installed, and operated at the U.S. Army Rocky Mountain Arsenel (RMA) in Colorado which, by technical investigation, appears to be capable of incinerating the orange in an environmentally safe manner. The RMA incinerator is used to destroy mustard agend and many of the problems associated with the incineration of mustard and Orange are similar. The problems arise from the similarity between mustard and Orange as regards certain physical and chemical properties and environmental impact. These problems include: fuel conditioning, high temperature incineration, acceptable effluents, real time monitoring and drum disposal. The problems are handled at RMA; but, the facility is necessarily of considerable value, and the waste feed rate of 2 gallons per 
minute (gpm) requires considerable time to incinerate a given quantity of material. The information below regarding the RMA facility has not been reviewed by the U. S. Army, nor has any action been taken to contract the RMA facility for Orange incineration. Incineration of $2.3 \mathrm{mill}$ ion gallons would require approximately 27 months. The RMA system can operate at $>2,000^{\circ} \mathrm{F}$ with a stay time of two to six seconds. Although no actual Orange incineration data is available, it is felt that such operating conditions will adequately destroy the herbicide and.TCDD. In addition a caustic scrubber installed on the system will provide additional treatment of the combustion gas. The elimination of the liquid discharge, the slow rate of incineration, the combustion gas treatment, the monitoring systems installed, and the drum cleaning capability make this option extremely attractive.

Based on technical and environmental considerations, incineration in the CONUS in units such as the RMA facility could be safely accomplished. Unfortunately incineration units of sufficient capacity are located near centers of populations and industry, and these areas are al ready marginally acceptable from a polut ion viewpoint because of presently occurring degrees of air pollution. Furthermore, local and state governments are generally opposed to the importation of waste for disposal within their areas of jurisdiction. For the above reasons, incineration in the CONUS is not considered a viable alternative.

\section{REPROCESSING}

Reprocessing of Herbicide Orange would convert it into commercial products (n-butyl esters of $2,4-D$ and $2,4,5-T$ ) containing acceptable levels of TCDD. The process would differentially destroy the TCDD or concentrate it into a readily disposable waste. To date (September 1975) three chemical companies have submitted process descriptions in support of bids to reprocess the herbicide. The basic processes proposed all basically attempt to selectively separate the valuable components of Herbicide Orange from the TCDD contaminant. Classical chemical me thods, i.e., solvent extraction, distillation or absorption, would be employed to concentrate the 
TCDD. The TCOD impurity would then be disposed of by incineration. The process descriptions have been evaluated by EPA and the Army Environmental Hygene Agency. The processes appear promising with respect of $2,4-0$ and $2,4,5-T$ recovery as well as satisfactory destruction of the dioxin contaninant. However, sufficient processing questions have been raised (e.g., disposal of dioxin wastes and in-process destruction) to warrant a mandate for pilot studies (up to 150 gallon capacity). The objectives of the pilot study would include: (1) confirmation of process claims, (2) determination of impact of scale-up unit on process efficiencies, (3) evaluation of dioxin destruction and disposal, (4) estimation of possible dioxin contamination of the environment.

The Scientific Advisory Board's Ad hoc Committee on Disposal of Herbicide Orange met for a final as sesment of all research data and a discussion of options in March 1974. Rough estimates for the cost of each major viable option were presented.

\section{TREATMENT}

Complete Incineration

Complete Biodegradation

Fractionation and Incineration

Fractionation and Biodegradation

Complete Chlorinolys is

Fractionation and Chlorinolys is

Reprocessing/liemogenous Mixing/Sale
ESTIMATED COST

(\$ MILLION)

3.657

2.235

4.031

2.754

11.462

9.033

2.153

Although these data suggested that the reprocessing option was most viable, there were no assurances given by EPA that once selected, registration of appropriate inventory would follow. The use option (as Orange Herbicide) was not considered in the final analysis for two reasons (1) no registration existed for the n-butyl ester of 2,4-D and 2,4,5-T and (2) the market for a n-butyl ester formulation was thought to be minimal. Moreover, field tests with Orange iferbicide in 
western Oregon in 1973 drew an unusually and controversial reaction from the public. Nelvspapers in the area (and throughout the Country) generally carried a very derogitory view of the use of this chemical (as Orange) in reforestation programs.

Biodegradation of the herbicide in an isolated area in western Utah appeared feasible. However, newspaper coverage in the Fall of 1973 , also made this option "politically" sensitive. The suggestion in the newspapers that the Air Force was seeking a site to "dump" 2.3 million gallons of toxic surplus herbicide from Vietnam nade the selection of an appropriate location impossible. For similar reasons, the incineration of Orange within the Continental United States (CONUS) appeared unrealistic.

The obvious option was considered to be incineration outside the COilus. Since sorile of the European Countries had used specially designed ships for incineration at sea, this option was considered the "most likely to succeed". As a consequence, the Environmental Health Laboratory at Kelly AFB, Texas, was tasked with preparing an environmental impact statement for the incineration of lierbicide Orange. The final statement "Disposition of Orange Herticide by Incineration" was released in ibvember 1974.

Destruction of Herbicide Orange is pending final evaluation of reprocessing and a review of the status of 2,4,5-T Herbicide by the Environmental Protection Agency. If the latter two actions are negative, then the Air Force will seek a permit for ocean incineration of Orange. Destruction of the herbicide by incineration could begin in the Spring of 1976.

It is ironic that such large quantity of herbicide, so widely used in the United States, and so critical in World Agriculture, will be destroyed because it was used in a highly controversial military conflict. When given the option of whether to use it for the benefit of mankind or destroy it as a symbol of protest against war and the abuse of our environment, the American public has choosen the latter. 
A PLAN FOR DETERMIINIIIG WASTE PESTICIUE DISPOSAL PRACTICES IN EPA REGION VIII

The disposal of unwanted pesticides and used pesticide containers has been a problem for some time. Murray ${ }^{1}$ reported approximately 130 million containers were used for agricultural pesticides with another 100 million aerosols for home use. A study conducted in Mississippi described unused pesticide and pesticide container disposal practices. Specifically, 27.3\% of unused pesticides remained in storage, $24.2 \%$ were buried, $15.6 \%$ were applied to the soil surface, $11.0 \%$ went to a city dump and the remaining $21.9 \%$ were either burned, returned to the dealer, disposed in a sanitary landfill or city sewage system. The pesticide containers were either disposed of by burial, 18.4\%; delivered to the city dump, $16.6 \%$; retained by owner, 15.3\%; sold, $11.4 \%$ or burned, $10.5 \%$. The remaining containers, $25.8 \%$, were either crushed, formed trash piles, or returned to the dealers.

Fox and Delvo ${ }^{2}$ sampled 8,500 United States farmers to collect information on pesticide containers associated with crop roduction. The study revealed that the predominant method of disposal was burning, $49.2 \%$, followed by private dumps, $18.9 \%$ Eleven percent of the pesticide containers were retained. The remaining containers, $31.9 \%$ were disposed of in commercial dumps, buried, returned to dealer, left where sprayer was filled, left in the field, or disposed of in some unspecified manner. Pratt $^{3}$ reported an Interdepartmental Task Force on Pesticide Container Disposal was instituted to deal with used pesticide containers in California. Results of a collection program initiated by the Task Force showed only partial success, as only $39 \%$ of the agricultural districts participated with 22,000 containers being collected.

The proper disposal of pesticide containers is essential to assure a minimum hazard to man and the environment. Disposing of pesticide containers in open dumps

Presented by Gary J. Mihlan, Research Associate, Institute of Rural Environmental Health, Colorado Epidemiologic Pesticide Studies Center, Colorado State University, Fort Collins, Colorado 
or fields may pose a threat to public health. rehlbach and $/ 1$ lliams ${ }^{4}$ documented three poisoning cases resulting from improperly disposed pesticide containers. Proper disposal metiods must be employed.

Realization of the pesticide disposal problem has been gradual, but progress is being made. Private industry along with local state and federal governmental agencies are working to assure that safe disposal of pesticides and used pesticides containers is a ccomplished.

Enabling legislation for the establishment of disposal procedures was published in the Federal Environmental Pesticide Control Act of $1972^{5}$ section 19 of the Act required the Administrator of the Environmental Protection Ayency to "establ ish procedures and regulations for the disposal or storage of packages and containers of pesticides and for the disposal or storage of excess amounts of such pesticides, and accept at convenient locations for safe disposal of pesticide the registration of which is cancelled..." Subsequently, on May 1, 1974, guidelines were published in the Federal Register ${ }^{6}$.

The May 1, 1974 guidelines dealt with disposal methods for various pesticide types as well as used pesticides containers. The Octover 15, 1974 Federal Register in part amended the May 1, 1974 federal guidelines, such that several disposal methods were not considered acceptable. 7 These methods included open dumping, open burning, water dumping, deep well injection, and other methods which would contaminate food or feed supplies. The remaining disposal methods of incineration, buried in a specially designated landfill, soil injection, and storage are acceptable. The problen was not simply one of disposal, but disposal in an environmentally safe manner.

Considering the published guidelines of May 1, 1974, and Dctober 1, 1974, the Environtental Protection Agency has no specific disposal systen for pesticide wastes in most states within Region VIII (Coloracio, Utah, Vlyoming, Horth Dakota, South Dakota, Montana). Table I lists general ground disposal facilities by state. Much variation exists between states concerning the quality and quantity of these poten- 
tial pesticide disposal sites.

Within the Region the State of Montana in conjunction with the Environmental Protection Agency is cooperating to conduct a pesticide disposal demonstration study Jealing with container and waste pesticide management. In the Region as a whole, no indication of the need for pesticide and pesticide container disposal is evident. The disposal problem must be defined in order to develop a safe disposal system. Information specifying the type, quantity, and location of unwanted or excess pesticides and numbers of used pesticide containers requiring disposal must be determined before a functional disposal program can be developed.

The EPA in Region VIII has subsequently contracted with the Colorado Epidemiological Pesticide Study Center at Colorado State University to determine the current status of pesticide disposal in the Region. The objective of the study is to determine and describe the disposal practices in EPA Region VIII by obtaining an assessment of the quantities, types, and locations of such pesticide products requiring disposal. Since the disposal practices of commercial applicators, pesticide formulators, governmental agencies, and rural, suburban, and urban users would differ considerably the study was developed in four parts.

\section{Commercial Applicators}

The commercial applicators studied are ground applicators, aerial applicators and structural applicators (pest control operators). Due to the large number of applicators in the Region (Table II), not all are contacted in each state. A 20\% randomly selected sample is chosen.

Upon identification and selection of the conmercial applicators a questionnaire form is developed. The form is designed to obtain information on the types, quantities, and locations of unwanted or excess pesticides requiring disposal. Information concerning numbers, types, and locations of used pesticide containers is also questioned.

The questionnaire is divided into three parts (refer to Appendix). Part A lists personal information and is used to locate the geographical area where disposal is 
needed. Information obtained on quantities of pesticides applied, number and types of application equipment, and number of employees is used only for stratification.

Part $B$ deals with unwanted or waste pesticides. This is concerned with those pesticides that are no longer used, those that have been only partially used, or those that have become contaminated or otherwise made useless. Pesticides involved in spills are also included. Methods of disposal and storage and handling practices are questioned.

Part $C$ of the questionnaire deals with the disposal of used pesticide containers. The numbers and types of containers, along with storage and handling practice information is requested. In each part questions are designed to allow for standard interpretation by all respondents.

Duestionnaire forms are mailed to the applicators. A cover letter is included explaining the study and a metered return envelope is provided. Upon mailing the questionnaire a three week period is allowed for response. After the three week period persons who do not return the forms are sent follow-up letters to request cooperation in the study. In the following weeks respondents and non-respondents are subsampled.

The subsample of respondents are presonally interviewed to serve as quality control. Questionnaire forms which have been previously submitted by the respondent are used. The personal interview involves reviewing the questionnaire to determine the accuracy of information given and the ability of the respondent to correctly interpret each question. Approximately $40 \%$ of the respondents are interviewed for qual ity control.

The subsample of non-respondents is initiated to assure an adequate sample size for the study. Data received from respondents is biased in some respects. Respondents. perhaps are more conscientious or knowledgeable of proper disposal practices. Itonrespondents, therefore, are al so subsamoled and personally interviewed. Approximately $20 \%$ of the non-respondents are contacted.

11. Pesticide Formulators 
Pesticide formulators in the Region are studied. The sampling scheme is basically the same as described for commercial applicators. Due to the large numbers of formulators in the Region (Table 11 ) only a $20 \%$ randomly selected sample is studied.

A questionnaire form is developed to obtain pesticide disposal information. The questionnaire designed for pesticide formulators is essentially the same as for the commercial applicators. Minor alterations are instituted to design questions relevant to the pesticide formulator industry. As described in Section 1 Commercial Applicators, the questionnaire is divided into three parts; Personal Information, Unwanted or Waste Pesticides, and Used Pesticide Containers.

Questionnaire forms are mailed to the sample. A cover letter and a metered return envelope is provided. A three week response period is allowed. After this time persons who do not respond are sent follow-up letters encouraging response. After two weeks respondents and non-respondents are subsampled and personally interviewed.

111. Mosquito Abatement Districts and Governmental Agencies

Mosquito Abatement Districts within Colorado and Utah are studied. Governmental agencies are contacted only within Colorado. Three state governmental agencies are studied. These agencies include the Colorado Division of Wildlife, Colorado Weed and and Pest Control Districts, and the Colorado Department of 1 ighways. Three federal governmental agencies studied include the U.S. Forest Service, Bureau of Reclamation, and Bureau of Land Management.

The questionnaire form used is similar to that described in Section I Commercial Applicators. The form consists of three parts; Personal Invormation, Unwanted or Waste Pesticides and Used Pesticide Containers. Questionnaires are mailed with three weeks allowed for response. After this time a follow-up letter is mailed to nonrespondents encouraging response.

Few non-respondents are anticipated from the Districts and governmental agencies. 
If there are non-respondents these are personally intervieved.

IV. Rural, Suburban and Urban Users

Ideally to conduct the study, a listing of all rural, suburban, and urban users for each state is desirable. Since this is not possible at present, only one area is studied, Larimer County, Colorado. A sample of 50 rural users, 50 suburban users, and 50 urban users are selected. The procedure employed involves personal interviewing of each user.

The questionnaire used to conduct personal interviews is similar to that described in Section 1, Commercial Applicators. Disposal practices for the rural, suburban, and urban users will differ considerably from commercial applicators. The questions are designed for multiple responses. Common household disposal practices are included in the questionnaire.

After obtaining information from respondents and personal interviews of nonrespondents, data is transferred to forms for conputer coding and subsequent analysis. Conclusions can be formed concerning pesticide disposal practices and quantities and types of pesticides and used containers requiring disposal. Disposal methods and storage and handling practices for unwanted pesticides are presented as a percentage employed. Pesticides requiring disposal are presented as mean quantities per applicator. The disposal and storage method for used pesticide containers and container rinsing practices are given as percentages. Uumbers and types of used containers requiring disposal are given as a mean number per applicator. In this manner an accurate description of pesticide disposal practices can be presented. Results may then be extrapolated to the total population in the Region.

Presently the study has obtained some of the date from the users and handlers. Information from the ground, aerial, and structural applicators, pesticide formulators, mosquito abatement districts, and governmental agencies has been obtained. The rural, suburban and urban applicators have as yet not been contacts. 
Preliminary results of the study show a $15 \%$ response from the sample of applicators and formulators in all states except Montana. Montana has yet to be contacted. A $100 \%$ response is anticipated from the mosquito abatement districts and local state and federal governmental agencies. If there is non-response, the districts or agencies will be personally contacted to obtain information.

Data from ground, aerial and structural applicators and pesticide formulators indicate very few unwanted pesticides within the Region requiring disposal. Specifically, 2642 liters (700 gallons) and $953 \mathrm{~kg}(2100$ pounds) of pesticides were listed as requiring disposal. - This was from a total of five applicators/formulators. The largest area of concern is with used pesticide containers requiring diposal. In this case a.pproximately 39,000 used containers were listed by respondents as stored or disposed of in the last year. The data given is preliminary. There exists much variability between applicators/formulators concerning numbers of containers and quantities of unwanted pesticides requiring disposal.

The remainder of the study is anticipated to require nine months for completion. A final report will be submitted to the Environmental Protection Agency, Region VIII, Denver, Colorado. The study will be available to state agencies for referral in developing individual state pesticide disposal facilities .

The study has incorporated a broad cross-section of the pesticide users and handlers within the Region. Not only have the commercial applicators been sampled but rural, suburban, and urban users, as well as governmental agencies. From such a diverse population the pesticide disposal needs and practices can be evaluated. Current disposal practices utilized can be determined as well as quantities, types, numbers, and locations of pesticide products requiring disposal. This information will provide a data base for future development of a pesticide disposal system. 
TABLE I

WUMBER OF DISPOSAL SITES BY STATE WITHIN E.P.A. REGION VIII

Colorado

Utah

Wyoming

North Dakota

South Dakota

Mont ana
255 land disposal sites

Greater than 2001 andfills and dumps

54 open durnps, 31 modified sanitary landfills

10 sanitary landfills, 402 dumps

4001 andfill sites, $85-90 \%$ are cons idered open dumps

651 andfill sites, 64 non-landfill or dump sites 
TABLE $\mid 1$

NUMBER OF PESTICIDE APPLICATORS AIID FORMULATORS IN E.P.A. REGION VIII Aerial Applicators 710

Ground Applicators 766

Structural Applicators 150

Pesticide Formulators

144

TOTAL

1770 


\section{REFERENCES}

1. Murray, W.S., The Wavy Disease Vector Ecology and Control Center, Pesticide Storage and Disposal, The Seminar on Environmental Ecology and Pesticides, May 25-27, 1971, Naval Air Station, Alameda, California.

2. Fox, Austin S. and Delvo, Herman W., Federal Working Group on Pest Management, Pesticide Containers Associated With Crop Production, Proceedings of the National Converence on Pesticide Containers, Hew Orleans, Louisiana, Hov. 28-30, 1972, Washington, D.C., U.S. Government Printing Office, December 1972.

3. Pratt, Robert H., California Collection, Transportation and Disposal Systems, Proceedings of the Region VIII Pesticide Disposal Conference, U.S. Environmental Protection Agency, Denver, Colorado, April 4, 5, and 6, 1973, pp. 65-94.

4. Gehlbach, Stephen H., Williams, Wilton A., Pesticide Containers, Their Contribution to Poisoning, Arch. Environ. Health, Vol. 30:49-50, 1975.

5. Federal Environmental Pesticide Control Act of 1972, Public Law 92-516, 92nd Congress, Oct. 21, 1972.

6. Regulations for Acceptance and Recommended Procedures for Disposal and Storage, Federal Register, Vol. 39, Ho. 85, Part IV, P. 15236, Hednesday, Hay 1, 1974.

7. Proposed Regulations for Prohibition of Certain Acts Regarding Disposal and Storage, Federal Register, Vol. 39, p. 36867, Tuesday, Oct. 15, 1974. 
PNEWIK

(b) 
PESTICIDE DISPOSAL SURVEY ZUESTIONINAIRE

Ground, Aerial and Structural Applicators

A. Personal Information

Name

Company

Address

Number of Employees

Number and types of application equipment

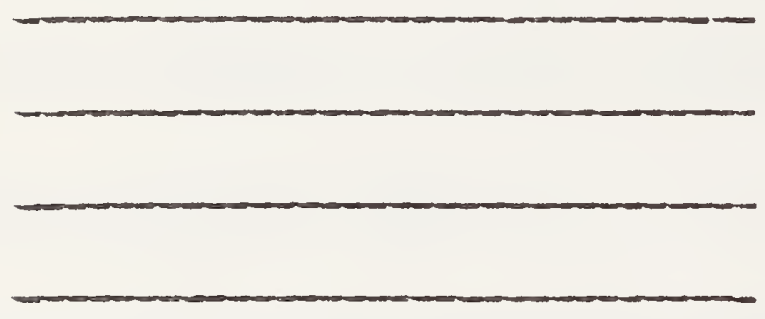

Give an approximation of quantities of pesticides applied within the last year.

I bs

gallons

B. Unwanted or Waste Pesticides

1. Do you ever store or dispose of unwanted pesticides? Yes __ ilo __ If no, proceed to Part C.

2. Check the method or methods used to dispose of unwanted pesticides. Please list the three main methods, having (1) as the most frequently used.

Incineration *Public Dump

Private Dump

Holding Pond

Sewer

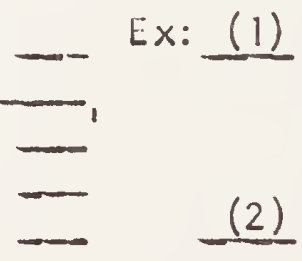

* Open dumping of refuse with no earthen cover.

$\therefore:$ San i tary Landfill

***Hodified Sanitary Landfill

Collection and 5 torage

Spread on Ground

Return to Vendor

Other (specify)

$*$ Hanaged refuse site with a daily cover of earth.

th: Weekly cover of earth over refuse.

3. List the type, amount, and EPA registration number of unwanted pesticides disposed or stored in the last year. Also list the condition of containers in which the unwanted pesticides are in.

Pesticide ilame (lbs. or gal.)

Ex.: Kel thane

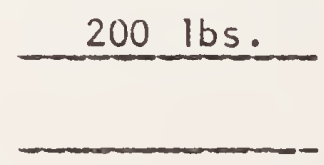

EPA registration number

707-66-AA

*Container Condition 
*Container conditions -

Good - sealed tight, no visible dents or other physical damage.

Fair - loose seal, slight dents or scratches.

Poor - not sealed, dented, rusty, or leaky

4. Indicate the type, size, and numbers of containers unwanted pesticides are stored in prior to disposal.

a. Metal:
1 gallon
5 gallons
20 to 30 gall lons
50 to 55 gallons=--
b. Glass:

$$
1 \text { gallon }
$$

c. Paper:

4 to 5 pounds

20 to 25 pounds

d. Plastic:

$$
1 \text { gallon }
$$

5 gallons
20 to 25 pounds

50 pounds and over

other (specify)

Other (specify)

50 pounds and over

other (specify)

e. Other types of containers (specify)

Less than 1 pint 1 quart

1 gallon

5 gallons

29 to 30 gallons

50 to 55 gallons

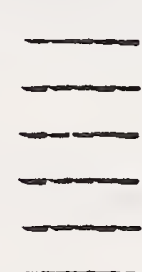

Less than 3 pounds

4 to 5 pounds

20 to 25 pounds

50 pounds and over

other (specify)

5. List the area in which unwanted or waste pesticides are most frequently stored prior to disposal.

Secured area, enclosure Open Area (field)
Inside building

other (specify)

6. Are containers which are used to store unwanted pesticides labelled according to their contents?

Always _ Sometimes __ Never __ Don't know __ No response _ _

7. Are stored unwanted pesticides mixed together or maintained in separate containers by pesticide type?

Always Mixed

Always Separated
Somet imes Mixed Don't know
Sometimes Separated

Response 
1. Check the method or methods used to dispose of unwanted pesticide containers. Please list the three main methods in order of use, having (1) as the most frequently used.

Returned to dealer

Incineration

Buried

:Public Dump

Recycled as scrap steel

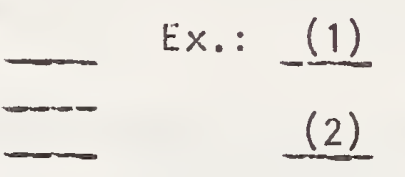

*H. San itary Landfill
*Hodified Sanitary Landfill
Retained and reused
Sold to private individuals
Other (specify)

* Open dumping of refuse with no earthen cover.

tit Managed refuse site with a daily cover of earth.

*it* Weekly cover of earth over refuse.

2. This question deals with the number, size, and types of used pesticide containers stored or disposed of in the last year. Please estimate the number of containers stored or disposed of in the provided size categories for each type of container listed. Fill in either the weight or volume. If there are no containers in any type of size category, please fill in "g".

a. Metal containers:

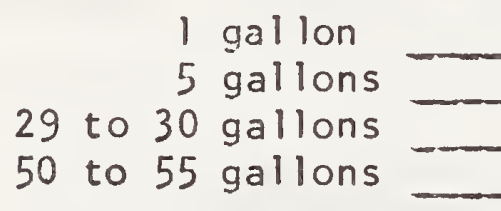

20 to 25 pounds 50 pounds and over 50 to 55 gallons Other (specify)

b. Glass containers:

$$
1 \text { gallon }
$$

0 ther (specify)

c. Paper containers:

$$
\begin{array}{r}
4 \text { to } 5 \text { pounds } \\
20 \text { to } 25 \text { pounds }
\end{array}
$$

50 pounds and over other (specify)

d. Plastic containers:

$$
\begin{array}{ll}
1 \text { gallon } & \text { other (specify) } \\
5 & \text { gallons }
\end{array}
$$

e. Other types of containers (specify)

Less than 1 pint
1 quart
1 gallon
5 gallons
20 to 39 gallons
50 to 55 gallons

Less than 3 pounds

4 to 5 pounds

20 to 25 pounds

50 pounds and over

Other (specify)

3. Are containers rinsed out prior to disposal? If never rinsed, proceed to question 5 .

Always rinsed Sometimes rinsed Hever rinsed Don't know

4. Please check the method or methods which most closely describe how the rinse is disposed of. Indicate the top two methods used, having (1) as the most frequently used. 
4. cont.

Buried in a sanitary landfill

Poured down sewer Run on to ground Piun into waterway Reused as pesticide dilutent _._. Other (specify)

5. List the area in which pesticide containers are most frequently stored prior to disposal.

Secured area, enclosure upen area (field)
Inside of building

Other (specify)

6. Do you use a central collection point for disposal of pesticide containers?

Yes _. No

7. At the present time do you have any disposal problems requiring immediate attention? Yes No If yes, what?

Leaky containers

Chemical changes (separation)

Excessive amount of pesticide Other

8. Conments: 

Most of you here are perhaps well aware of the kinds of problems caused by animal depredations and that vertebrate animals, particularly the carnivores, seem to generate the greatest degree of interest and emotion. Most people seem either to support or oppose the concept and programs dealing with predator control. Few seem to be indifferent or to have no opinion.

The effects of political and administrative influence on direction and effectiveness of such programs are often thought to be clear and obvious. In reality, such influences and results are usually complex and often obscure. Any at tempt to analyse, document and thoroughly discuss such cause-effect patterns would require an immense amount of time and voluminous writing. Perhaps, therefore, a relatively simple discussion of trends, programs and the cancellation process for the three major chemicals employed in predator control may serve to illustrate a rather complex pattern.

Animal damage control has always been an essential element in protection of human interest. No country, including this one, could have progressed from a primitive stage without such practices and control has been employed in the United States since the first European settlers arrived. Indian history records some similar activities.

Early in this century professional rodent and predator control was initiated by the U.S. Department of Agriculture (USDA) Bureau of Biological Survey on federal lands for protection of agricultural interests. It grew during the first World War in the interest of providing essential food and fiber for a nation at war. It continued under USDA direction until 1939 when the program was transferred to the Department of Interior (USDI) and became the Branch of Predator and Rodent Control 
(PARC) but with little change in responsibilities. Its purposes remained primarily those of protecting agricultural crops, animal and human health, forest and range, wildife and other resources. It continued with these duties and programs for 26 years.

Following recommendations of the Leopold Committee (1964), in 1965 PARC was given a new name, Division of Wildlife Services (DWS) with increased duties in wild ife enhancement and management. These have continued to the present time with a greater emphasis on enhancement and a lesser emphasis on damage control.

Prior to 1915, animal damage control had primarily been the responsibility of individuals, producer groups, counties or states, with additional effort by municipalities and public health agencies. Growing federal involvenent by USDA, USDI, and public health agencies has occurred since that time. Concern for human health and safety, cleanliness of human food, public utilities, aircraft safety and other factors have dictated more extensive and intensive state and federal involvement for several decades.

Gradually, various cooperative arrangements have evolved between federal, state, county and municipal agencies. Producer and other interest groups have often been a part of such programs. Several types of programs exist, from professional federal, state or county activities, to Extension predator control, or completely independent efforts. In most localities, professional control is augmented by individual effort, producer groups and sport hunters. Bounty programs still exist in some areas although they appear to be losing their appeal. In general, they seem to be considered expensive, wasteful, ineffective and often abused. This seems particularly true where highly intelligent problem animals exist and continue to cause depredations.

Until recently, USDI-DWS had contracts with state and county agencies in 16 of the 17 western states. Kansas was the exception. Some USDI officials have repeatedly expressed a desire to return these program responsibilities to the states. Since 1972, 
several bills have been introduced in Congress in attempts to accomplish this change. Federal funding to supplement state efforts has been proposed in most of these in the attempt to secure congressional and local support. In most of these bills, however, some reservation of authority to direct or control the extent of damage control and methods to be employed by the states has been reserved to USDI.

For different reasons, therefore, agricultural and environmental groups have occasionally found themselves aligned in opposing similar bills. Usually, this has meant opposition to state-controlled programs by environmental groups because they foresee a loss of their influence if state programs are more respons ive than USDI to agricultural concerns. In contract, agricultural groups have often opposed these bills because they felt that proposed restrictions on control methods were too severe. As a result, no federal bill has become law, although the states of South Dakota, Colorado and Washington have adopted state control programs in the past two years. Thus, there appears to be at least a partial return toward more state and local responsibility in such programs, although far greater restrictions by federal regulations and policy have been imposed and options in control are largely limited to mechanical control methods.

Methods employed in predator control may include exclusion by fences, some repellent techniques, close herding of livestock, guard dogs and lethal mechanical or chemical techniques. Lethal chernicals have been severely restricted since 1972, however. Repellent techniques have shown little but short term benefits and effective reproductive inhibitors have not been developed. Taste aversive agents and collars containing toxic chemicals are being evaluated but are not proven effective methods. There has been a great deal of political and administrative pressure recently to adopt the toxic collar, however.

Suggestions for control methods and sources of program funding are many and varied, including those denying that a problem exists and insisting that damage 
control is not needed. Others prefer a return to the so-called "balance of nature" in the belief that this would provide an immediate and painless solution. Opposition to predator control is at least partially due to the tremendous shift of population to metropolitan areas during this century. More than 90 percent of Americans now reside in urban centers, some removed by several generations from an interest in or concern for the agricultural sector.

The majority of antagonism to damage control is centered in urban areas. Among the reasons often cited are opposition to hunting, trapping, firearms, killing of animals, multiple use of public lands and abuse of land by agriculture interests. Others are a disbelief that damage occurs, or that it is a problem of any magnitude, and often a belief that "management" would solve any problem that does exist. Occasionally, the belief that man is vegetarian by nature and should niether kill animals nor eat meat is given. These beliefs and support by environmental groups, primarily from urban areas, have led to extensive continued efforts to prohibit animal damage control methods and programs.

Such efforts are evident in current restrictions and in bills introduced by state and federal legislators to further restrict chemicals and mechanical control methods, including traps and firearms. Numerous bills to abol ish control programs have also been proposed. It has become increasingly apparent that a much greater degree of public understanding and knowledge of the need for control is essential. Factual information and education programs are obviously the only solution if effective control programs are to continue.

Opposition to predator control programs, particularly to the use of chemicals, increased in the decade prior to 1972. The Leopold Report (1964) increased and focused attention on these activities and opposition became highly critical with reports of eagle deaths due to shooting and chemicals in 1970-71 in the mountain states. These were apparently major factors in appointment of the Cain Committee 
in $1 y 71$ to review predator control in the western states and in cancellation of the major chemicals ușed in control prograris.

Somewhat unique in the Leopold Report (1964) and the Cain Report (1971) were the differing conclusions, even though the re had been no basic change in the livestock industry, the predation problem, the extent of the control programs, the chemicals employed, and the area and techniques for application of control methods. In addition, both comittee chairmen served on the other comittee.

The Leopold Committee concluded that the steel trap is one of the most damaging control methods in the sense of its being nonselective and that much unnecessary killing of wildlife in the western United States has resulted from the use of such traps in coyote control. It is further stated that when properly applied, 1080 (sodium monofluoroacetate) meat baits are effective and humane in control of coyotes with very little damaging effect on other wildlife.

The Cain Committee did not agree. It stated that the use of chemicals is likely to be inhumane and nonselective and recommended that landowners be trained in the use of steel traps as a major method of coyote control.

Ostensibly, the decisions to cancel predator control chemicals and subsequent orders and actions by the President and agency administrators were based on the Cain Report. This report was released to the public following Executive Order, No. 11643, issued by President Nixon on February 8, 1972. Evidence has gradually accumulated since then, however, indicating that other administrative and political influences were major factors. Some review of chronology is necessary at this point.

The Cain Committee was appointed in early 1971 and apparently began its review in late July under contract to the president's Council on Environmental Quality (CER) and USDI. The contract supposedly required completion of the report by 0 ctober 30 , 1972, allowing approximately three months for data gathering, review, and writing of the report. Apparently the report was completed by November and first printed in December 1971, al though there are statements of record that was not printed until January 1972. 
On July 9, 1971, at Estes Park, Colorado, USDI Secretary Morton included the

following statements regarding the Cain Committee and its findings in his address

to the National Wildlife Federation Conservation Sumit.

"Well before the Jackson Canyon eagle kill last month, I agreed to cooperate with the Council on Environmental Quality to initiate a complete review of predator control activities to identify problem areas and seek their resolution. This study team will be composed of seven non-governmental professionals recognized for their expertise in the wildlife field...

The task Force has been charged with the responsibility of examining all aspects of the issue, including poisoning carried on by the private sector and state and local government as well. They have been instructed to examine with care the economics of national insurance programs as a possible alternate to predator control and to recommend any changes which may be needed in our present administration of this program.

Let me add that I absolutely guarantee that the findings of these experts will be given a full hearing and review by wool growers and cattlemen, as well as wildlife interests. The study al ready has received funding from Interior and the Council on Environmental Quality, and I personally pledge that performance will follow program so that our imperiled predators will not perish in a sea of platitudes."

Al though public hearings were "absolutely guaranteed," none were held. The Cain Committee Chairman stated on March 14, 1972, in Mexico City in a panel discussion that "I should say that we first considered public hearings. We decided, however, that there simply was not enough time to hold public hearings, to gather testimony, and to digest it and because of the slowness of the hearing process." One is forced to wonder why there was such a shortage of time.

During this same panel discussion in response to a question regarding public hearings not being held, USDI As sistant Secretary Reed stated:

"I would be delighted to give you the answer. I think it is about time that it came right out onto the surface and everybody knew. We all understand the political truths of life. The President received the recommendation sent by the chairman of the Committee to the Secretary of the Interior, and said: 'It's about time I got a recommendation like that and 1 intend to act upon it. However, I think that it is of such national interest that 1 reserve it as my right to give it in the Environmental Message which is scheduled for February 8 th. There will be no disclosure of the report nor your recommendations to me until that time."' 
If Secretary Reed was accurate in quoting the President, there would appear to have been prior decisions made with regard to cancellation of these chemicals. That this was the case appears to be supported by a stipulation filed in the U.S. District Court for the District of Columbia, apparently late in 1971, in relation to two civil actions filed in that court early in 1971 . The relation of the stipulation to the civil actions appears to be as follows:

Civil Action 564-71 was filed with the Court on March 16, 1971. The action filed by Counsel for the Defenders of Wildlife and the Sierra Club against USDI and individuals within the Department contained a series of allegations that USDI activities in damage control were damaging to wildlife including endangered species, particularly with regard to chemicals used in damage control. The action requested an injunction prohibiting USDI from conducting control activities alleged to be seriously affecting certain wildlife species. A second Civil Action, No. 775-71, was filed in this Court on April 14, 1971, by the Humane Society of the United States and its California branch against USDI and these same individuals. This complaint contained a series of allegations with regard to the use of predacides and requested a permanent injunction to prohibit USDI from conducting such control activities.

The related stipulation was apparently filed in late 1971 with the District Court and contains the following information.

\section{STIPULATION FILED UNDER SEAL}

Defendents by their attorneys, have requested that plaintiffs not pursue, before February 15, 1972, their motions for permanent and/or preliminary injunctions, and have represented to them as follows:

1. That the draft of a study under the direction of Dr. Stanley A. Cain will be finalized and published in early January 1972; and

2. That as a result of recommendations contained in 
the Cain study and other considerations defendants presently intend to make major changes in policies and programs relating to the existing animal damage control program now conducted by them, and publicly to announce these changes on or before February 15, 1972; and

3. That defendants will need, following publication of the Cain report, additional time, to February 15, 1972, to finalize such plans; and

4. That defendants intend to conclude the present predator control program insofar as killing by poison is concerned, except that defendants intend to continue bird and rodent control programs and animal control research; and

5. That after the changes in policy and programs have been publicly announced, defendants intend to implement such policies and programs as soon thereafter as is practicably possible; and

6. Nothing here in shall be used by any party as an admission or as a statement against interest by any party.

As a result of the foregoing representations plaintiffs agree not to pursue on or before February 15, 1972, their motions for permanent and/or preliminary injunctions and further agree not to pursue, on or before February 15, 1972, other motions or discovery in connection with their lawsuits. In the event that plaintiffs thereafter reactivate their lawsuits, defendants agree to forego any contention that plaintiffs are foreclosed from relief on account of the delay.

This stipulation shall remain in camer and sealed until this litigation is concluded. 
The stipulation was signed by counsel for plaintiffs in both civil actions and was apparently sealed until July 1972.

Disposition of these two Civil Actions apparently was as follows: a stipulation of dismissal of Civil Action 564-71 was filed with the Court in March 1972 stat ing that "It is hereby stipulated and agreed that the above case is dismissed without prejudice." In May 1972, a similar document dismissing Civil Action 775-71 was filed with the court. Both documents were signed by counsel for plaintiffs and defendents. On February 8, 1972, Executive Order Ho. 11643, prohibiting use of the major predacides on federal land and by federal employees was issued by the White House. It provided for emergency use of these chemicals only if in each specific case the head of the agency involved provided written justification for use following consultation with the Secretaries of Interior, Agriculture and Heal th Education and Welfare and the Administrator of EPA. Additional criteria for emergency use were an essential need for protection of human health and safety, or wildlife species, or "prevention of substantial irretrievable damage to nationally significant natural resources."

On February 10, 1972, USDI issued a news release indicating that it had ceased to formulate, distribute or use these chernicals for predator control on federal lands and had ceased to use any toxic chemicals with secondary effects in control of rodents, birds, or other species. Only mechanical methods were authorized for use by USDI personnel and chemicals were removed from field use as rapidly as weather conditions permitted.

On llarch 9, 1972, the EPA Administrator issued orders cancelling and suspending these chemicals (sodium cyanide, strychnine and sodium monofluoroacetate) for use in predator control. In that order (PR notice 72-2) the Administrator expressed the agency's commitment to review the status of registration for these three chemicals for use in predator and rodent control in rangeland areas. He indicated that "this commitment grew out of grave concern surfaced by the reported deaths of some 20 eagles 
killed by the misuse of thallium sulfate." Since this compound had not been an operational USDI professional control tool for some 15 years, the "misuse" presumably would have been by non-professionals. Perhaps the interest in reviewing the professional use of chemicals was wholly desirable. It is difficult, however, to see any direct relationship between correct professional use of the three major chemicals and illegal non-professional use of a completely different compound.

In addition, the EPA Administrator cited the Cain report and "a detailed petition submitted to this Agency by several distinguished conservation groups urging that the registration of these compounds be cancelled and suspended immediately." It appears, therefore, that political and administrative influences were significant in the cancellation process.

During the same period and continuing into late 1973, testimony by EPA and USDI administrators at congressional hearings for review of predator control policy and related matters repeatedly emphasized that chemicals were not needed in such programs since other alternatives such as mechnical methods and livestock management practices were effective and adequate. Testimony, speaches and news releases by administrators also indicated that losses to predators were likely exaggerated and were not as severe or serious as livestock interests considered them to be. Many individuals in livestock production and operational predator control programs disagreed substantially with some of these premises, but had little effect on Agency or administrative policy.

It appears, therefore, that there are some aspects of the cancellation process for these chemicals which at the least are somewhat unique. In addition to the conduct and dismissal of the civil actions against USDI mentioned earlier, there are others which might be considered. Comparison of the use and cancellation of these chemicals with DDT points to some major differences.

The predacides were used largely in the 17 western states in contrast to DDT which was used nationwide. The amount of DDT used annually exceeded the amount of 
the predacides useci ty several thousand fold. UDT has shown adverse effects on several nontarget wildife species whereas the professional use of the predacides has not shown such effects. UDT was cancelled following extensive public hearings over an extended period whereas no hearings were held prior to cancellation of the predacides. The predacides were cancelled for professional use without prior knowleuge by the affected industry and largely due to illegal use of a different compound by non-professionals. If all the chemicals registered for control of plant and animal species, only those used for predator control were cancelled by executive order. In the President's message to Congress, August 1972, the restrictions on DDT and the predacides were cited as significant contributions of his Administration to protection of the environment; 1972 was a presidential election year and from the revelations of Watergate one is led, inescapably, to wonder what effect election concerns had on earlier administrative decisions which were widely supported by environmental groups.

Uespite earlier insistence that chemical methods were not needed for predator control, USDI requested and was granted emergency use of the $11-44$ sodium cyanide device by EPA in May 1974 for protection of sheep and goats where mechanical controls alone were founu inadequate. A USDI report on the use of that device for the period from June through October 1374 indicated that in some areas and under some conditions mechanical controls were ineffective and that combined mechanical and chemical predator controls were necessary to prevent or reduce severe livestock losses. Experimental pernits for tine device were also granted by EPA to several western states in 1974 to determine if it was effective in reduction of losses. USDI has since requested EPA to allow registration and full operational use of the $11-44$. A hearing on that request for registration and others from several states was held by EPA in August 1975 and apparently registration will be allowed. It appears, therefore, that political and and administrative influences were significant in altering predator control methods 
and programs, first by removing the chemicals and secondly by atteripting to bring at least one of them back into operation.

of additional significance was the notice of intent by the EPA to hold hearings in regard to cancellation of these chemicals for rodent control filed in June 1973. "Informal hearings" were announced and held in September and October 1973 at Washington, D.C., Denver, Colorado, Dallas, Texas and Sacramento, California. All interested parties were invited to produce relevant evidence. The cancellation notice was withdrawn in December 1973 with the following statement as part of the withdrawal:

"Wased upon both the informal hearings and the Agency review, EPA has concluded that sufficient valid scientific and economic data do not exist at this time to justify the continuation of the procedures begun by the June 19, 1973 Hotice. Accordingly, I hereby withdraw the Wotice of Intent to hold a hearing and thereby withdraw the proceedings initiated by that Hotice."

The significance of this statement is that far more hard scientific data existed with regard to rodent damage and chemical rodent control than existed on predator damage and chemical control. Therefore, if insufficient evidence existed for cancellation of these chemicals as rodenticides, it is difficult to assume that evidence existed for cancellation of them as predacides.

It seems apparent that a suit brought by the state of wyoming and other plaintiffs against the EPA and other defendants in regard to cancellation of the predacides was a factor leading to review of the Executive Order (11643) and agency policies. On June 12, 1975, the District Court in Cheyenne, Wyoning, granted the state a temporary injunction setting aside the EPA order which cancelled and suspended registration of these chemicals. The Court also ruled that the EPA was required by its own regulations to follow due process by allowing the livestock interests to be heard and that it must file an environmental impact statement relative to the cancellation of tirese chenicals. That ruling is now under appear by the EPA.

A new Executive Order, î. 11870, was issued by Fresicient Ford on July 18, 1975. It replaced Jrder No. 11643, tut with few real changes. Section $1(5)$ adds constraints on devices and additional concerns for individual animals which were not included in 
.10. 11643 and is, therefore, more restrictive than the earlier order if strictly interpreted. jection $3(\mathrm{c})$ allows the head of an agency to authorize the use of sodiun cyanide on an experimental basis to control predator or bird damage to livestock on federal lands or in federal programs for no wore than one year. Environmental groups appear to feel that except for Section $3(c)$, there are greater restrictions on use of chemicals than existed in order 11643.

There appears in raality to be very little real change from order 11643 since the energency permit authorized USOI to use the $11-44$ in protection of livestock, except on rederal lands. - Insofar as experimental use is concerned, there appears to be no obvious advantage on federal lands since similar conditions for research can readily be found on private or state lands.

There is the possibility of different methods of application, i.e.: the toxic collar, which can be used experimentally by USDI under Order 11870 . USDI has applied for registration of this device, a toxic collar fitted to the neck of sacrificial sheep, to provide a somewhat different approach as indicated in the following comments from Sciences, August 1, 1975:

"The Council on Environmental Quality (CEQ) has announced that the government will permit new experimental use of sodium cyanide to kill coyotes that attack sheep. The latest decision is a modification of a 1972 executive order that bans predator poisoning on public lands except under emergency conditions.

Coyotes are responsibly for the death of 3 to 5 percent of sheep herds in the West (25 percent in some areas), said CEQ head Russell Peterson. Shepherds find the losses hard to bear, since the sheep industry has been steadily declining since the 1940's.

The simplicity and restraint that characterizes the new idea perhaps explains why it wasn't thought of before. Most coyotes don't like eating sheep (rabbits are their staple), but few love them, and will attack again and again. They prefer lambs, preferably tethered, and they attack by lunging at the neck. So a poisonous collar - necklace of sodium cyanide capsules--has been devised. A few lambs will be tethered at the edge of their herd and fitted with the collar. A passing coyote with an eye for sheep will leap at at the animal's neck, his teeth will puncture a cyanide pellet, the poison will squirt in his mouth, and viola! he will drop dead. Peterson says tests in large pens show that this works, and furthermore, the lamb generally escapes unharmed. The project has virtues ecologically not only because of its selectivity but because carrion 
eaters happening upon the dead coyote will not be poisoned by eating the flesh.

Peterson, in answer to a question, said it was possible the technique could have an adversive conditioning effect on whole populations of coyotes--one day, perhaps, breeding an antisheep attitude into the subconscious of the race, as it were.

Defenders of Wildlife, a Washington group that fought for the 1972 poison ban, has criticized the recent action on the grounds that it opens loopholes for indiscriminate poisoning programs to resume. The government argues that relaxing the order to allow experimental programs will permit development of more effective and environmentally sound means of predator damage control."

CEQ appears to have had, and still to have, substantial influence on administrative decisions related to the predacides and appears to be pushing heavily for adoption of the collar as a totally new concept. However, neither the concept or the collar are really new, but came from suggestions of control personnel in field operations and are several years old. Reasons they were not adopted are several, but included are these: physical limitations in applying these to animals weighing from 6 to 150 pounds or more and logistic problems of application, including the number of sheep that must carry collars, or placement of the few sacrificial sheep into suitable locations to intercept the coyotes. Equally as great are the limitations due to intelligence and behavior of the coyote species. However desirable that the toxic collar may be, it is questionable that it will be effective as the major method of coyote control. Experimentally, the toxic collar should be extremely interesting to test and, hopefully, will be at least partially effective. It does seem, however, that widespread application would provide a logistics problem to stagger the imagination, particularly where coyotes are traveling long distances to kill, where their travel routes and direction are unknown, and where they fail to see the attraction of tethered lambs compared to those running free. These factors appear to carry little weight in CEQ if the report in Science is accurate and there renains little doubt that political and administrative factors continue to function; 1976 is also an election year.

Political and administrative actions normally occur in response to the interest, 
activity and size of pressure groups. In numbers, the rural population is distinctly outweighed. The 1973 census revealed that 4.5 percent $(9,472,000)$ of the total U.S. population $(210,036,000)$ were farm residents. The total number of U. S. farms reported in 1975 was 2,819,000, of which 146,200 were involved in the sheep industry. If one assumes that the rural population is evenly distributed across these farms, approximately 5.2 percent of rural residents were involved in sheep production in 1975, less than one-fourth of one percent $(0.23$ percent $)$ of the entire U. S. population. It is not surprizing, therefore, that agriculture, particularly sheep producers, has relatively little influence on political and administrative decisions.

The livestock industry has been further hampered by a lack of unified, clear, consistent opinions, policies and objectives on the predator issue. Individual violations of laws and regulations, including the use of toxic chemicals, have also contributed to a loss of influence and to increased opposition in all aspects of animal damage control. The extension of opposition to include other wildlife management practices, particularly hunting and trapping, has occurred. In many instances, a lack of understanding of carrying capacities and population dynamics seems to be coupled with a belief that "the balance of nature" is all that is needed.

Particularly critical has been opposition to animal control on public lands, accompanied by growing opposition to multiple use of such areas for hunting, grazing and other purposes. The beneficial effects of hunting to protection of habitat by preventing overuse by game animals and damage to adjacent agricultural crops is of ten not recognized. Without question, overuse of land by game animals as well as livestock contributes to loss of vegetation, decreased water retention and erosion. However, moderate grazing by livestock increases forage by reducing wildfires, by suppressing some plant species and stimulating regrowth of others. Grazing, therefore, is not necessarily undesirable. This depends on the intensity of use and moderate use can benefit wildlife in many areas.

Private agricultural land is at least as important to wildlife as public land by 
providing habitat the year around for many species and critical habitat, particularly in the winter, for such species as deer and elk. Thus, the importance of agricultural land to wildlife as well as food production suggests that economic survival of producers is essential.

Given the opposition to control programs and the influence of opposition groups, it is not unusual that "panaceas" such as repellents, aversive agents and "livestock management" are so appealing to legislators and administrators. From any point of view an effective nonlethal method which offered both the relief sought by producers and acceptance by opposition groups would be ideal and highly attractive politically. However, all methods are subject to limitations imposed by physical, biological and climatic factors. From current knowledge of predator biology, behavior, intelligence and adaptability, it is evident that a wide range of options and flexibility in application are essential to solving individual problems. Livestcck management, repellents, predator-proof fencing and other nonlethal methods may be useful in many situations but they cannot be effective under all conditions.

Theoretical approaches to "solve" the predator issue have often been directed with little prior knowledge or consideration of limiting factors and many "simple solutions" have been offered. The difficulty in application has been the lack of simple problems to which they apply.

A quote attributed to P. A. M. Dirac, irobel Laureate, seems particularly appropriate: "It is also a good rule not to put overmuch confidence in the observational results that are put forward until they have been confirmed by theory." It often appears that this philosophy has been applied with little restraint in administrative approaches to animal damage control over the past several years. It would seem even more valid to apply the inverse, that confidence in theory can only be supported by confirmation in fact.

It is possible that additional new control techniques such as specific attractants 
and reproductive inhibitors may be developed. Such methods could provide alternatives for management of damaging species and may offer one of the best options for nonlethal control in the future. It is highly unlikely, however, that nonlethal methods can ever provide all necessary control in the immense variety of habitat types, climatic conditions and damage situations that are known to exist. Management of predator populations will be necessary and political reality suggests that this too must be recognized. 


\section{References}

Audobon Leader. 1975. Vol. 16(14):1. July 25.

Allen, D.L., Chairman. 1972. Report of the Committee on Horth American Wildlife Policy. Transactions: North American Vildlife Conference 38:152-181.

Cain, S.A., J.A. Kadlec, D.L. Allen, R.A. Cooley, M.H. Hornocker, and F.H. Wagner. 1971. Predator Control - 1971. Report to the Council on Environmental Quality and the Department of the Interior by the Advisory Committee on Predator Control. University of Michigan Press. Ann Arbor. 207p.

Cain, S.A. 1966. Statement before the Fisheries and wildlife Subcomittee of the House Committee on Merchant Marine and Fisheries. Hearing, Predatory Animal Control Policies. February 2, 1966. 13 p. (mimeo.).

Colorado Department of Agriculture, 1975. Colorado Agricultural Statistics Colorado Crop and Livestock Reporting Service, Bulletin. July 1975.

Connolly, G. and W.M. Longhurst. 1975. The effects of control on coyote populations: a simulation model. University of California Experiment Station. Bulletin. (in press).

Conservation News. 1975. Predator control and the sodium cyanide collar. Vol. $40(16): 2-4$.

Council for Agricultural Sciences and Technology. 1975. Multiple use of public lands in the seventeen western states. Report No. 45. Department of Agronomy, lowa State University. Ames. 50010. 13p. (Mimeo.).

Council on Environmental Quality. 1972. Third Annual Report. U.S. Government Printing office. Washington, D.C. 450 .

Council on Environmental ¿uality, 1973. Fourth Annual Report. U.S. Government Printing Office. Washington, D.C. $498 p$.

Council on Environmental Quality. 1974. Fifth Annual Report. U. S. Government Printing office. Washington, D.C. 597p.

Court Records. 1971-72. United StateS District Court. District of Columbia.

Environmental Protection Agency. 1972. Pesticides Regulations Division PR Notice 72-2. 6p. (mimeo.). March 9, 1972.

Environmental Protection Agency. 1973. FIFRA Docket No. 294. (In re use of certain rodenticides.) Notice of Withdrawal of Proceedings. December 4, 1973. 3 p. (mimeo)

Howard, W.E. 1974. The biology of predator control. Addison-Wesley Module in Biology, No. 11. Cummings Publishing Company. Menlo Park, Cal ifornia. 48p.

Knowlton, F.F. 1972. Preliminary interpretation of coyote population mechanics with some management implications. Journal of Wildlife Management 36(2): $369-382$. 
Knowlton, F.F. 1973. Using population mechanics in management schemes. Proceedings. Great Plains Wildlife Damage Control Workshop. Kansas State University. Manhattan. December 10-12, 1973. pp. 11-16.

Leopold, A.S., S.A. Cain, D.M. Cottam, I.W. Gabrielson, and T.L. Kimball. 1964. Predator and rodent control in the United States. Transactions: North American Wildl ife Conference 29:27-49.

Marsh, F.M. 1975. National Woold Grower 65(8):4. August 1975.

Morton, R.C.B. 1971. Remarks at the National Wildlife Conservation Summit. Estes Park, Colorado. July 9, 1971, 5p. (mimeo).

Poole D.A., L.M. Talbot, A.S. Leopold and H.P. Reed. 1972. Special panel: results and implementation of the Council on Environmental Qual ity Department of Interior predator control study. Transactions: North Americain Wild life Conference 27:395-409.

Presidential Documents. 1972. Executive Order 11643. Federal Register $37(27): 2875-6$. February 8, 1972 .

Presidential Documents. 1975. Executive Order 11870. Federal Register $40(141): 30611-13$. July $22,1975$.

Ruch, J.B. 1973. Long range objectives of the federal government in coyote management. Proceedings: Great Plains Wildlife Damage Control Workshop. Kansas State University. Manhattan. December 10-12, 1973. pp. 1-4.

Sciences. 1975. CEQ relaxes stand on predator poisoning - biter beware. Vol. $189(4200): 361$. August 1, 1975.

Science News. 1975 Lee Talbot: an ecologist for all seasons. Vol. 107 (16):260. April 19, 1975 .

United States Department of Agriculture. 1974. Number of farms and land in farms. Annual report. Statistical Reporting Service. December 30, 1974.

United States Department of Agriculture. 1975. Annual cattle inventory. Statistical Reporting Service. February 3, 1975.

United States Department of Agriculture. 1374. Annual hog inventory. Statistical Reporting Service. December 3, 1974.

United States Department of Agriculture. 1975. Annual sheep and goat inventory. Statistical Reporting Service. January 28, 1975.

U.S. Congress, House of Representatives. 1973. Predatory animals. Hearings, Subcommittee on Fisheries, Wildlife Conservation and the Environment. ilinety-Third Congress, First Session. March 19-20, 1973. Serial No. 93-2. $397 p$.

U.S. Congress, ilouse of Representatives. 1973. Predator control. Hearings Comnittee on Agriculture. Winety-Third Congress, First Session. September 18, 20 and $21,1973$. Serial ivo. 93-00. $354 p$. 
U.S. Congress, Senate. 1972. Predator control and related problems. Hearings, Subconmittee on Agriculture, Environmental and Consumer Protection. June 2-3, 1971. iNinety-Second Congress, First Session. 220p.

U.S. Congress, Senate. 1972. Predator control and related problems. Hearings, Subcommittee on Agriculture, Environmental and Consumer Protection. Uecember 14-20, 1971. Ninety-second Congress, Second Session. 668p.

U.S. Congress, Senate. 1973. Predator control. Hearings, Subcomittee on the Environment. Ninety-Third Congress, First Session. March 27-79, May 10, 1973. Serial No. 93-28. 514p.

U. S. Department of Interior. 1966. Fish, Wildlife and Pesticides. U.S. Government Printing office. Bulletin. 12p.

U.S. Department of Interior. 1972. Interior, CEQ release Advisory Committee study report on predator control. News release. $2 p$. (mimeo.) February 8, 1972.

U.S. Department of Interior. 1974. M-44 Efficacy Data. A report on emergency use of the $M-44$ cyanide ejector for canid damage control. June 1 -October 1, 1974. 11p. (mimeo.).

U.S. Department of Interior. 1972. Use of poisons halted by Interior in animal damage control program. ilews release. 2p. (Mimeo.). February $10,1972$.

Wade, U.A. 1973. An assessment of the coyote problem in the Great Plains states. Proceedings: Great Plains Wildlife Damage Control Workshop. Kansas State University. Manhattan. December 10-12, 1973. pp.5-10. 
Today, I am going to discuss a natural method of controlling noxious or weed plants. This method involves manipulation of livestock in such a manner to provide desirable plants the opportunity to out compete undesirable plants; and ultimately increase the quality and quantity of desirable vegetation on Montana rangel ands.

First of all, before 1 become too deeply entrenched in my topic, I want to make it clear that this discussion is directed solely at control of noxious plants on native rangelands. Noxious plant control on farm lands, hay meadows, and irrigated pastures are beyond the scope of this paper. Also, if I make an inference that a particular plant is noxious, I am only referring to its successional position relative to a specific range site.

Philosophically, the Bureau is guided by one major axiom in its noxious plant control program, ranges in good condition with vigorous stands of high quality vegetation have fewer ncxious plants than overgrazed ranges in poor condition. A recent study conducted in Montana by SCS, documents numerous cases of resource deterioration by overgrazing. The results collected from about 80 range sites indicate that excessive quantities of big sagebrush, annual grasses, and undesirable forbs have invaded and significantly reduced the productive potential of such sites. (slide) Comparative compositional data, for grazed site versus nongrazed site near Helmville, Montana, shows that rough fescue (Festuca scabrella) occupies 78 percent of the vegetative composition on the ungrazed site and big sagebrush (Artemisia tridentata) is almost absent. Nearly the reverse is true on the adjacent grazed site. (slide) Overgrazed ranges stripped bare of protective desirable perennial vegetation offer an ideal environment for invasion of undesirable vegetation. Heavy continuous grazing

Presented by ilarry R. Cosgriffe, Range Conservationist, Bureau of Land Management, Billings, llontana 
increases undesirable plants and decreases tall grasses. Tall grasses with heal thy vigorous root systems will effectively control the establishment and spread of undesirable vegetation; and eventually undesirable plants are diminshed to their natural successional position.

The Bureau favors natural control techniques, i.e., specified livestock grazing treatments over cultural treatments. This strategy is necessary and logical, especially when one considers that BLM is responsible for management of surface resources over 9.3 million acres in Montana, North Dakota, and South Dakota. The success or failure of our program will directly affect an additional 3.7 million acres of adjacent, intermingled private and State land. This enormous land area consists of a heterogeneous mix of soil and vegetative types and rough, broken lands that simply are not suited to cultural treatments.

Most weed control strategies today, are oriented toward cultural control, but little attention is given to good livestock management before, during, or after the treatment is applied. Thus, the symptom is treated, rather than the factor directly responsible for the problem, whether it be the result of improper livestock grazing, or other man-caused land disturbances. Before mechanical or herbicidal treatments are applied, the ability of the land to respond to good grazing management technique must not be underestimated.

The control of noxious plants by manipulating class of livestock in comb ination with prescribed grazing treatments has been recommended and tested by various investigators at home and abroad. Turner (1969) in a three-year study in western Oregon found that utilization of Medusahead (Taenutherum asperum) infested ranges by sheep in early-late spring grazing treatments reduced Medusahead and allowed perennial grass species to become dominant. In a search of literature: Huss (1972) found that researchers in central Africa indicated goats might be more effective for controlling brush than herbicides and reported efforts to control brush by goats in Texas and Mexico 
was successful providing the goats were rotated between pastures. (Slides) Rest rotation grazing on the Leo Petrie federal range allotment north of Turner, Montana, improved the vigor and condition of silver sagebrush (Artemisia cana). Prior to initiation of the grazing system, continuous grazing by sheep maintained the plants in low vigor.

Baker (Personnel Communication) found in a study conducted in Montana that early spring grazing of leafy spurge by sheep reduced the rate of spread, and prevented seed production; and concluded that early sheep grazing in combination with herbicide applications was an effective control method.

Biological control of noxious vegetation offers great potential, especially if it is correlated with grazing management. In: some areas, the introduction of host specific insects has proved a worthwhile tool. Baker and Anderson (1974) are experimenting with leafy spurge hawkmoth to control leafy spurge.

The moth Calophasia is being tested on Dalmation toadflax in Idaho, Wyoming and Washington.

The moth Agroga Websteri attacks big sagebrush viciously; and it has the capability to effectively control dense monotypic stands of sagebrush.

In developing a strategy for controlling noxious plants, BLM is faced with two situations:

1. Controlling established stands of noxious plants, and

2. Prevention of the spread of existing stands and establishment of new infestations.

Conceptually, we approach each of these situations similarly. First, intensive livestock grazing management is advocated which involves the systematic rotation of livestock over a period of years to al low important perennial plants to regain vigor, produce seed and allow seedlings to become established. (Slide) In each allotment designated for intensive grazing managenent, the resource manager must select a key plant to manage for. Selection of the key plant is based on certain characteristics 
and qualities, such as, the plant provides excellent soil protection, perennial fibrorous or rhizomatous root system, generally reproduces from seed, and possesses a tall growth stature which offers it a competitive advantage over undesirable plants. Specific grazing treatments are designed to meet the growth needs of the key plant. By recognizing the various growth stages, i.e., leaf stages, flower stalk showing, flowering and seed ripe, the resource manager can predict the degree of root development and carbohydrate storage. The relationship between growth stage, root development and carbohydrate storage for I da fescue (Festuca idahoens is) is illustrated in Figure 1. The principles presented apply to other grasses, forbs, and shrubs, but of course, the growth stages and physiology differ from plant to plant.

In Montana's area of jurisdiction, a variety of grazing formulas are in operation. The number of treatments in each formula is dependent upon the amount of rest the resource manager decides is necessary for key plants to recover vigor, allow seed to ripen, allow seedling to establish and provide for lay-down of litter. Examples of grazing formulas that have proved particularly successful over the years are illustrated be low.

1. (slide) Nichols Coulee RCA - This allotment is located about 70 miles south of Malta, Montana, in the Missouri River Breaks. The allotment encompasses 88,000 acres. Two pastures are located in the C.M. Russell Wildlife Range and two outside. Square Butte RCA is located about 50 miles southwest of Malta near the Little Rocky Mountains. There are about 10,000 acres in the grazing system. The al lotment is divided into four equal pastures. The grazing formulas for each allotment are compared in Figure 2 . 
FIGURE 1
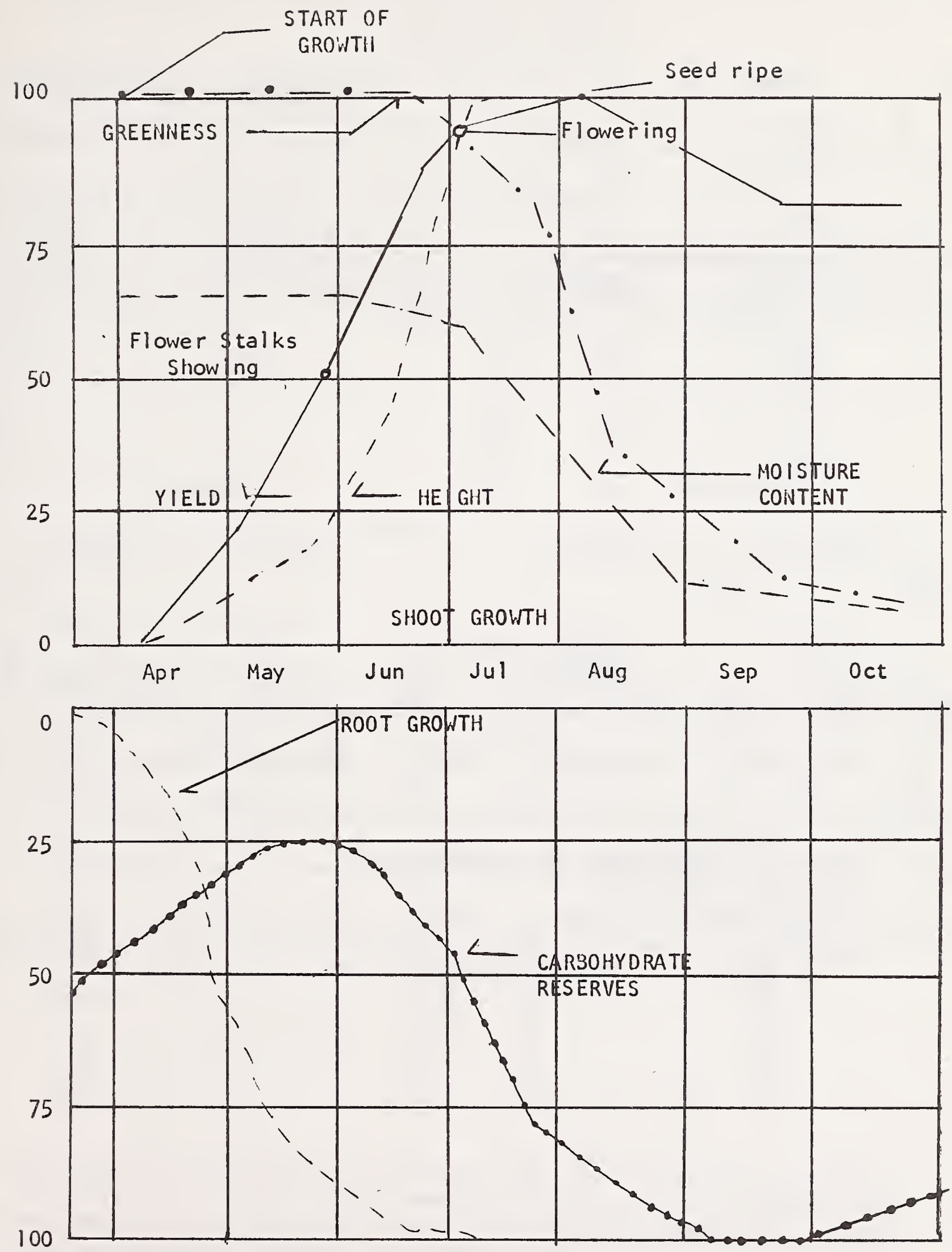
GRAZING FORIULAS

MICHOLS COULEE RCA

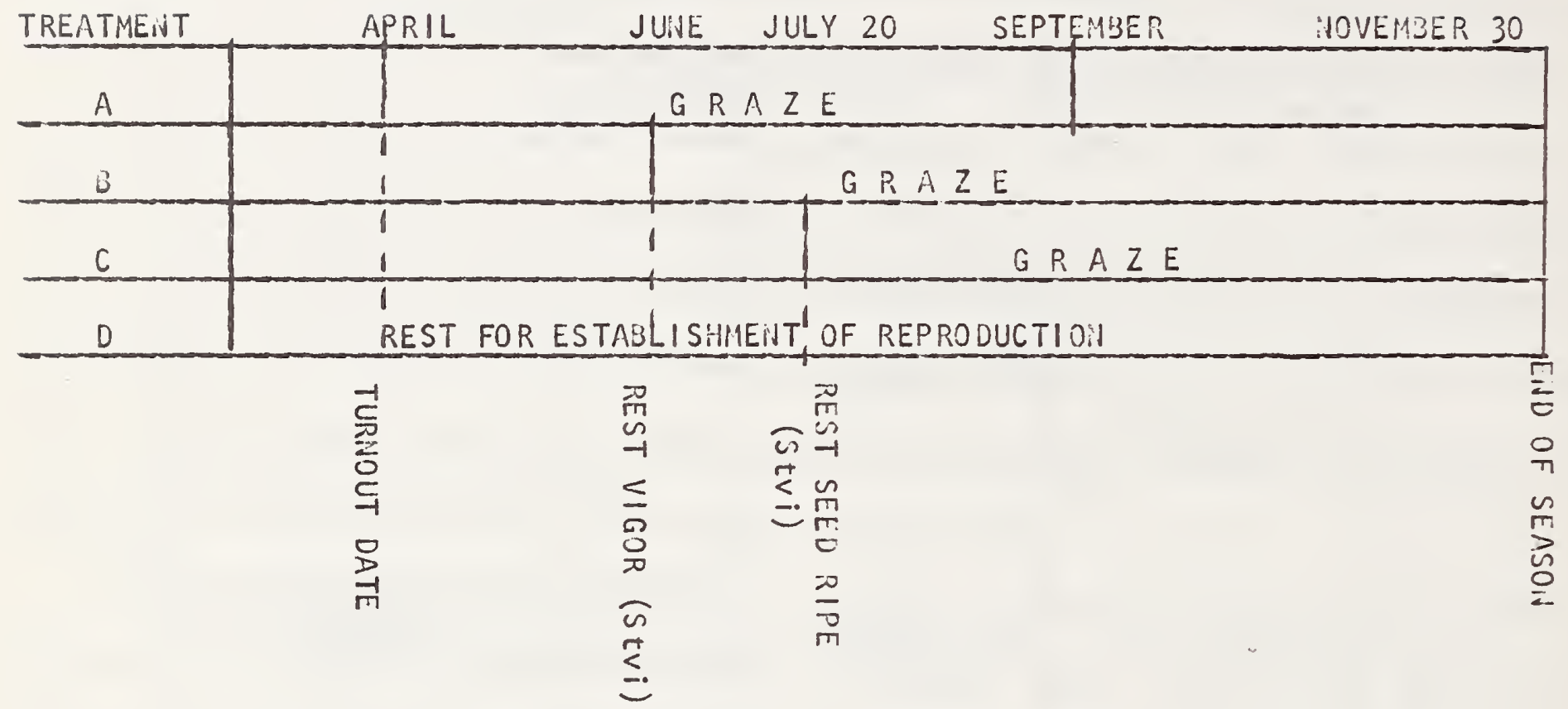

SQUARE BUTTE RCA

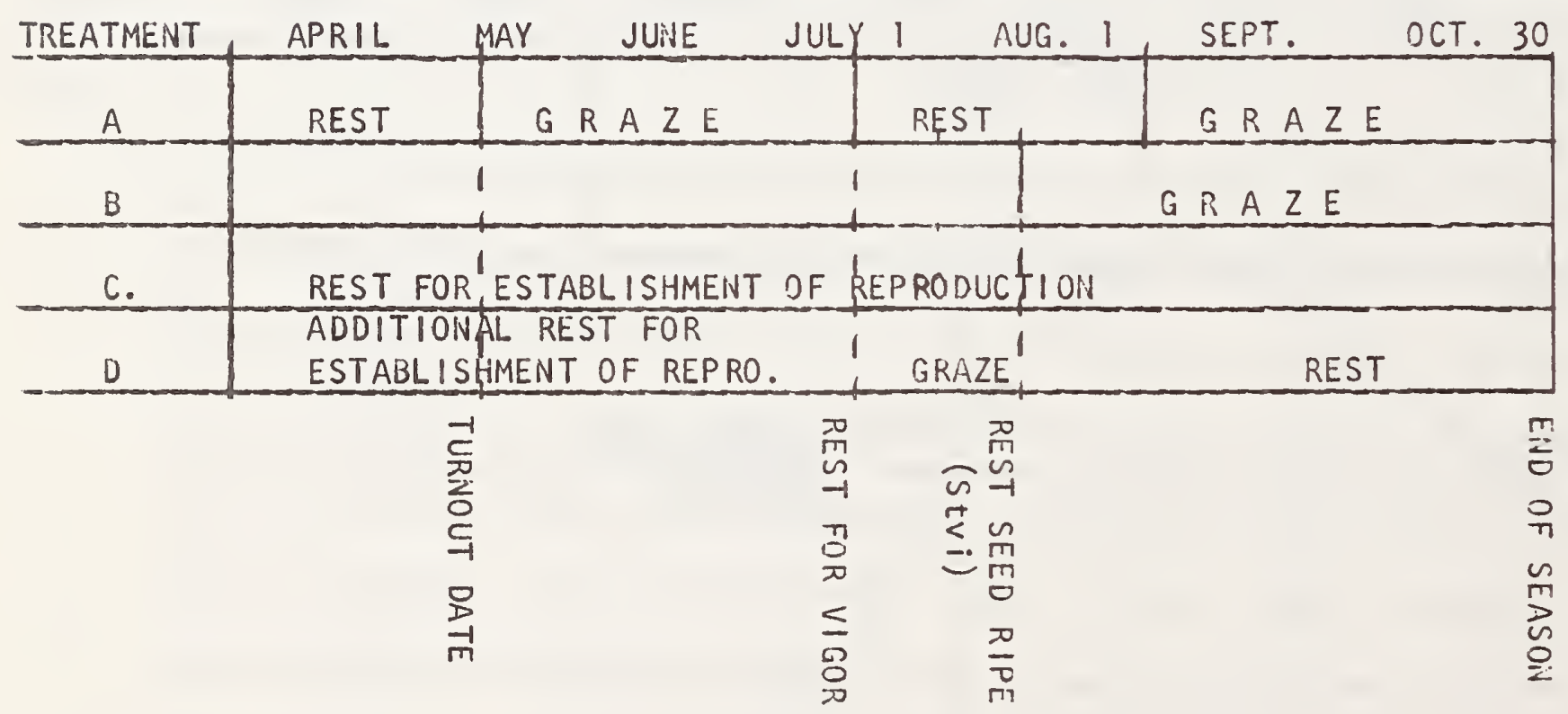

Figure 2. A pasture is necessary for each treatment in the grazing formula, thus four pastures are required to implement each formula. In four years, pasture will receive a prescribed sequence of the aforementioned grazing treatments. This sequence of treatment is referred to as one grazing cycle. 
2. (Slide) To facilitate operation of the grazing system, the rancher is provided a diagram of pasture moves over time as illustrated in Figure 3.

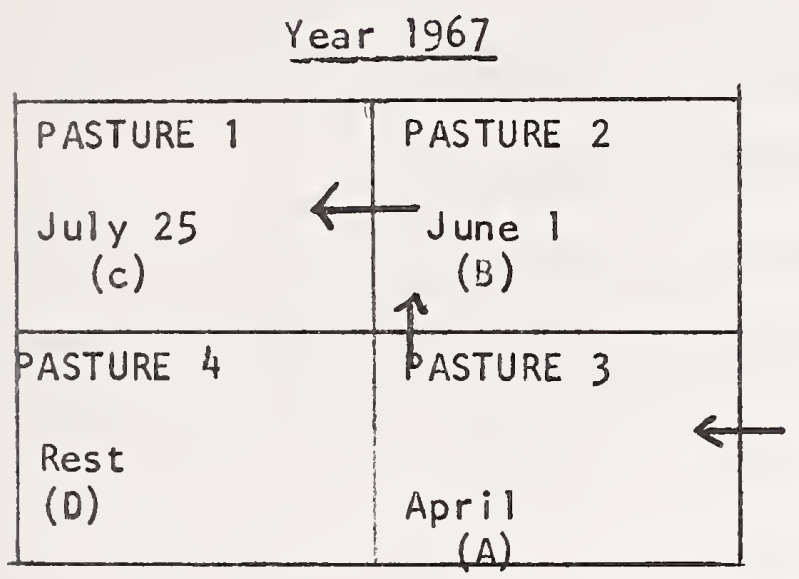

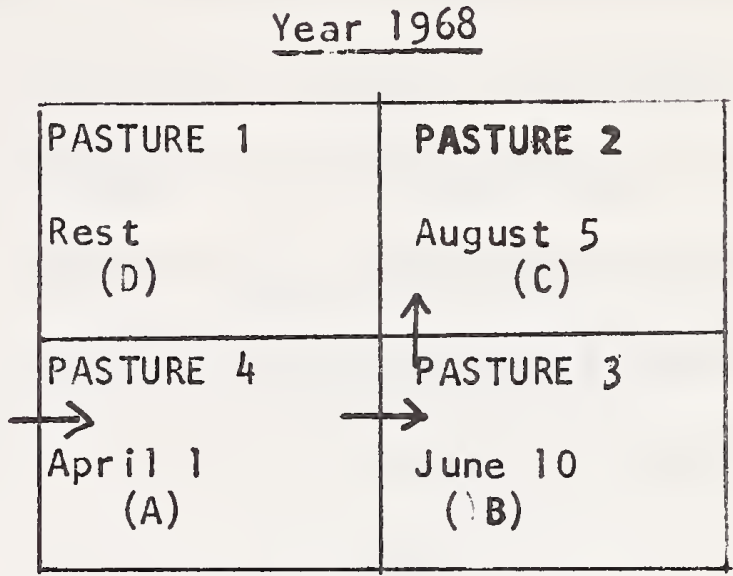

Year 1969

\begin{tabular}{|c|c|c|c|}
\hline & PASTURE 1 & PASTURE 2 & \\
\hline 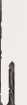 & $\begin{array}{c}\text { April } 1 \\
\text { (A) }\end{array}$ & $\begin{array}{r}\text { Res } t \\
\text { (D) }\end{array}$ & - \\
\hline 4 & PASTURE 4 & PASTURE 3 & \\
\hline & $\begin{array}{c}\text { June } 6 \\
\text { (B) }\end{array}$ & $\begin{array}{c}\text { August } \\
\text { (C)C }\end{array}$ & \\
\hline
\end{tabular}

Year 1970

\begin{tabular}{|c|c|}
\hline $\begin{array}{l}\text { PASTURE } 1 \\
\text { May } 28 \\
\begin{array}{l}\text { (B) } \\
\end{array}\end{array}$ & $\begin{array}{l}\text { PASTURE } 2 \\
\text { April } 1 \\
\text { (A) }\end{array}$ \\
\hline PASTURE 4 & PASTURE 3 \\
\hline $\begin{array}{l}\text { July } 20 \\
\text { (c) }\end{array}$ & $\begin{array}{r}\text { Res } t \\
\text { (D) }\end{array}$ \\
\hline
\end{tabular}

Figure 3. The rancher follows the arrows. The date varies for treatment from year to year based on the phenology of the key plant. 
The progress of the grazing system is monitored for one grazing cycle, generally four to five years. If our studies indicate that noxious plants are continuing to spread, then herbicidal or mechanical treatrients are employed. ilowever, if an especially aggressive species, such as leafy spurge is creating a serious problem, "cultural and grazing treatments are applied simultaneously.

The BLM in cooperation with ranchers, State of Montana, SCS, Forest Service, and Fish and Wildlife Service has implemented 244 grazing systems on two million acres of Wational Resource Lands and one million acres private and State lands in the last ten years.

Significant resource improvement is documented on grazing systems that have been operational for five to ten years. Resource improvement is monitored and documented by means of permanent photo stations. Photo stations are established on key sites as determined by professional resource managers. A permanent $3 \mathrm{ft} . \times 3 \mathrm{ft}$. plot is established, and over-plot (close-up) and general view photograpis are taken. Zuantitative data is also gathered and recorded on the $3 \mathrm{ft} . \times 3 \mathrm{ft}$. plot. Repeat closeup and general view photographs are retaken annually through the first grazing cycle. After the first cycle, photographs are generally retaken at the same time of the year and grazing treatment on a particular pasture received when the study was established. (BLM Manual 1969).

Over the years, BLM has catalogued many repeat photographs that show significant resource improvement (slide sequence Stellar Creek Allotment). A series of slides was presented showing significant improvement in plant composition by comparing original close-up or general view slides to repeat photographs, simultaneously. Undesirable plants that appear to be highly susceptible to grazing treatments designed to favor desirable vegetation are Broom snakeweed (Guitierrezia sarothrae), Fringed sagewort (Artemisia frigida), Gunweed (Grindelia squarrose), and wild licorice, (Glycyrrhiza lepidota). Studies indicate aforementioned plants are reduced appreciably and in sorne cases eliminated entirely in three to five years.

Highly competitive noxious plants, such as, $3 i g$ sagebrush (Artemisia tridentata), 
Cocllebur (Xanthium strumarium), Prickly pear cactus (Opuntia polycantha), cheatgrass (Bromus tectorum), and Japanese brome (B. japonicus) show a stronger resistance to grazing treatments. Where these species are established, it takes from five to ten years before noticeable improvement in plant composition occurs. The rate and degree of recovery is highly dependent upon site condition. Soil type and degree of soil loss are the major determining factors that regulate vegetation compositional changes. Thus, on sites where severe degradation has occurred change from undesirable to desirable plants is a long slow process. Over the long run desirable plants will gain the competitive advantage by reducing seedling establishment and survival of undesirables, provided grazing treatments are designed to meet the growth needs of desirable plants.

As supported by our studies, desirable plants exhibiting the capacity to control noxious plants are 1 isted below.

\section{Desirable}

Western wheatgrass (Agropyron smithii)

Green needlegrass (Stipa viridula)

Nutall sal tbush (Atriplex nuttallii)

Western wheatgrass

Green needlegrass

Rough fescue (Festuca scabrella)

$B$ luebunch wheatgrass (Agropyron spicatum)

Yellow sweet clover (Melilotus officinale)
Undes i rable

Cheatgrass \& Japanese brome Broom snakeweed

Fringed sagewort

Gumweed

Prickly pear cactus

Big sagebrush

\section{Alkali cordgrass (Spartina gracilis)}

Prairie cordgrass (Spartina pectinata)

Canada Wildrye (Elymus canadensis)

Western wheatgrass

\section{CONCLUSION}

Application of sound grazing management principles on three million acres over

the past ten years leads us to conclude that properly stocked grazing management systems are a powerful tool for controlling noxious plant species. In order to speed
Vild licorice

Cocklebur 
up the control process brought about by grazing management a relatively unexplored opportunity for manipulating class of livestock and introduction of biological controls, such as insects, offers infinite potential for natural control of noxious species. In order for cultural control programs on native ranges to be ecologically and economically successful, such programs must be subordinate and supportive in nature to good grazing management technique. 


\section{LITERATURE CITED}

1. Turner, Robert i3. 1969. Vegetation Changes on Medusahead Dominated Western Oregon Foothill Range Following Spring Sheep Grazing and Mowing. Proceeding Range Weed Research Meeting and Field Tours - Nevada - Cal ifornia: page 9.

2. Baker, L.0. Personnel Communication, September 10, 1975. Control of Leafy Spurge by Chemical and Non-Chemical Means. Montana State University, Bozeman, Montana.

3. Ross, Robert L. 1973. Soil and Vegetation Inventory of Near-Pristine Sites in Montana. USDA, Soil Conservation Service, Bozeman, Montana. 55 pp.

4. Huss, Donald L. 1972. "Goat Response to Use of Shrubs as Forage" adapted from Vildland Shrubs. - Their Biology and Utilization, USDA Forest Service Technical Report IHT-1 Intermountain Forest and Range Experiment Station, Ogden, Utah.

5. Baker, L. and N. Anderson, 1974. Leafy Spurge Hawkmoth in NOW, MSO - College of Agriculture, Bozeman, Montana, pp. 3-5.

6. Hormay, A.L. and Talbot, M.W. 1961. "Rest-Rotation Grazing - A New Management System for Perennial Bunchgrass Ranges." U.S. Dept. Agr. Prod. Res. Rep. 51, 43 p., illus.

7. Troughton, Arthur. 1957. "The Underground Organs of Herbage Grasses." Commonweal th Agr. Bureax, Bucks, England, Bull. 44, $163 \mathrm{p} .$, illus.

8. Bureau of Land Hanagement Manual 4412.22C, Release 4-34 dated 7/14/69. 
In April 1970, the US Department of Agriculture, Interior and Health, Education and Welfare, and the Surgeon General jointly declared all 2,4,5-T used in lakes, ponds and ditchbanks, and liquid formulations for use around homes and recreation areas to De an imminent hazard; LSDA suspended these uses and the Department of Defense simultaneously suspended all military uses of 2,4,5-T pending completion of further studies. Food uses were canceled except for use on rice which was appealed by the manufacturer. Following this Agency's creation we continued this policy. These actions were a result of the President's Science Advisor's announcement that scientific experiments indicated that the herbicide caused such teratogenic effects as cleft palate and systic kidney in test animals.

$2,4,5-T$ is now used only to control weed and brush growth on rice, rangelands, forests, and along rights of way, and contains in it a contaminant known as tdtraDioxin, which has some known evidence of causing birth defects in test animals.

In June 1974, the Agancy canceled the 2,4,5-T hearings requested by manufacturers due to inadequate analytic methodology, a euphemism meaning there was no data from which to draw conclusions. The past year the Agency has been constructing a system to gather and analyze the nedessary data about dioxin, and its possible envi ronmental effects.

The monitoring plan, started in March of this year, consists of two parts: 1) short monitoring plan, examining a collection of beef samples from rangelands of known treatment with 2,4,5-T. Approximately one-third of these samples have been tested, and all 125 samples should be completed by October 1975. 2) Additional areas of research activities to be implemented pending funding. These studies in-

Presented by Hurion Ray, EPA, Office of Festicides, to the Annual lleeting of the Pesticide Users Association, ilelena, Iontana 
clude monitoring studies of rights of ways, fish and wildlife, rice, persistency, combustion, and toxicity, and is expected to cost in the neighborhood of $\$ 1.2$ million.

The EPA will have a preliminary recommendation for the Administrator soon, and based on that recommendation the Administrator will make a decision on the re-opening of the hearings on 2,4,5-T, and other pesticides containing dioxin. 
SECTION FIVE, EXPERIMENIAL USE PERIIITS

Section 5, of the Federal Insecticide, Fungicide, and Rodenticide Act (FIFRA), permits to anyone who applies to the Administrator issuance of a permit in order to accumulate information necessary to register a pesticide when it is determined that the applicant needs such a pernit.

Also, the Administrator may:

1) if it is used on a food or feed, establish a temporary tolerance level for residues of the pesticide before issuing the experiimental use permit;

2) supervise use of the permit;

3) specify the types of study; and

4) grant to the States the right to grant experimental use permits.

In Section 5 regulations, publ ished last April 30th, application requirements are spelled out which permit, we believe, the necessary room to promote the desire for research, while prosiding necessary environmental controls; these permits are issued only after extensive review of comments from interested parties.

Additionally, a pesticide that is al ready registered for one product does not need to receive an experimental use permit if it wishes to test it on another product. 
I believe a brief explanation of the Agency's delays in disposing of Herbicide Orange is in order.

As you may know, in accord with Section $19(a)$ of the amended Federal Insecticide, Fungicide, and Rodenticide Act (FIFRA) the Administrator of the Environmental Protection Agency is required to establish procedures and regulations for the disposal or storage of pesticides, and excess amounts of such pesticides. Initial regulations under this section were published in the Federal Register on May 1, 1974, and additional rule making is now under final deliberation within the Agency.

In essence this policy states: "Before destroying a pesticide examine the useful values it has that are not damaging to the environment."

The EPA is now considering two primary methods for handling the disposal of Herbicide Orange: destruction and reprocessing.

EPA believes reprocessing is worthy of additional serious consideration, and may well be preferred to destruction. Reprocessing would involve the chemical breakdown of the herbicide, and, if current estimates prove correct, could return quantities of herbicide to normal channels of trade which are at least as pure as products currently being manufactured. The EPA has already received bids from manufactueres interested in examining the possibility of reprocessing. I emphasize, however, that all options are still in the exploratory phase, and because of the public concern about Herbicide Orange, no final decision will be made without opportunity for full public participation. 


\section{HERBICIDE ORAIIGE}

The recovery of useful value from pesticides in a disposal situation must be determined to be unfeasible before destruction can be considered. The possibility of recovering useful herbicidal value from the $2,4-D$ and $2,4,5-T$ components of Herbicide Orange with the concurrent destruction of the contaminant dioxin appear promising. Therefore, this avenue must be fully explored before a decision on destruction can be determined.

With respect to destruction by incineration at sea, the EPA feels satisfied that there is little likelihood of release of unburned Herbicide Orange ( and its contaminant, known as Dioxin) into the envi ronment. With waste of a similar chemical nature, but of lower caloric content, destruction efficiencies of up to 99.99 percent have been achieved, and never less than 99.0 percent. EPA is presently reviewing the Air Force's application to use the Dutch ship Vulcanus for at-sea incinerations. 
STRYCHNIINE

Strychnine is now permitted to be used in ilyoming against rabid skunks under Section 18, specific Exemption. EPA is now considering registering strychnine with the Center for Disease Control, which has applied for such registration at our urging. The Agency is of the opinion that the $\operatorname{CDC}$ is experienced in controlling disease vectores, and their decision-making would save time in emergency situations. This is in no way renoving our own Agency from regulating the use of this pesticide, or releasing the Agency from regulatory responsibilities. 
$11-44$

The $11-44$ is a mechianical device used to eject sodium cyanide into the mouth of canids when they activate it, after being attracted to it by a bait. It was developed in response to a need to replace the explosive shell of the Coyote Getter. Frederick 小. Dennistoun, Administrative Law Judge, for the Environmental Protection Agency, issued a recommendation on August 29,1975 to permit registration of the device with appropriate restrictions determined to be sound and under supervision of the U.S. Fish and Wildlife Service. Objections were made by environmental groups, including the respected National Audobon Society and Sierra Club, mainly concerning harm to non-target animals. However, Judge Dennistoun found the evidence showed the cond itions of use of the $M-44$ as embodied in actual practice under the experimental use permits avoid most of these dangers. He highlighted this point by citing the Fish and Wildlife Service statistics from Montana between July 1, 1974 and June 30, 1975, showing a total of 603 coyotes, 148 foxes (the target animals) and 23 skunks, 6 raccoons, 4 dogs and 1 badger killed by the $M-44$. Here the target animals account for 96 percent of the species taken. Administrator Train is to issue final decision Wednes day. 
There have been two substantial changes in the law passed by the House Agriculture Committee: review of Agency decisions by the Secretary of Agriculture and self-certification. These amendments will go to the floors of the House and Senate for a final vote within the coming weeks, along with the rest of FIFRA.

The Agency is now analyzing the amendments to FIFRA which requires review of Agency decisions by the Secretary of Agriculture, and the Aaministrator is expected to announce his position on the proposed legislation within the week. As for selfcertification, the Agency is opposed to the amendment which would allow any private applicator to use dangerous, restricted-use pesticides simply by saying he or she was competent to apply them, without having to demonstrate any knowledge of ability. On its face 1 believe it is obvious that this proposal would weaken the purpose of FIFRA, to protect the environment and people from the uncontrolled introduction of dangerous chemicals. 
EPA recognizes the necessity and value of pesticides for the adequate production of food and fiber and for the preservation of human health. It is for this very reason that we issue numerous experimental use permits for pesticide research and ultimately responsibility under the provisions of the Federal Insecticide, Fungicide, and Rodenticide Act (FIFRA) to regulate pesticides in order to ensure that they are used safely and without hazard to man or the quality of the environment. EPA is authorized under the Act to regulate the marketing of pesticides and to require that such products be registered with this Agency on the bas is of proven effectiveness and safety to humans, livestock, wildlife, and the environment. Should scientific evidence developed after a product's registration challenge its safety or efficacy, EPA is authorized to cancel or, in cases of more immediate hazard, suspend the product's registration.

Out of the total of about 30,000 registered pesticides products containing over 1,200 registered pesticides chemicals, only three major active cinemical ingredients-UDT, aldrin and dieldrin-- have finally been canceled by EPA since its inception in 1970. In addition, chlordane and heptachlor are presently undergoing both cancellation and suspension actions. He believe this record shows that the Agency has administered its responsibilities uncier the FIFRA in an even-handed manner, acting neither precipitously nor recklessly. It is important to note, that the three cancel lations were effected on the basis of substantial evidence of harm to human health and the environment. We thus do not feel that we have acted precipitously in exercising our cancellation authority.

I would also like to state that botn costs and substitutes have been among EPA's foremost considerations in our major cancellation actions to date, and are matters which receive this Agency's continuing attention. Understandable concern has been expressed in the past, for example, that a cancellation or suspension action could remove necessary pesticide tools from the farmer without leaving him with an acceptable substitute. The Substitute Chemicals Program was thus initiated under Public Law 93-135 
to "provide research and testing of substitute chemicals." The major objective of. this program is to determine the suitability of substitute chemicals which now or in the future may act as replacements for those uses, both mijor and minor, of pesticides that have been canceled, suspended, or are in litigation or under internal review for potential unreasonable adverse effects on man and the environment. The legislative intent of the Program is to prevent 1) the removal of pesticides from the market when there are no effective substitutes and 2) the substition of pesticides which, in fact, have the potential for effecting more environmental harm than the canceled or suspended use.

Under the Substitute Chemicals Program, each potential alternative pesticide chemical is reviewed considering all applicable scientific factors, including chemistry, toxicology, pharmacology, environmental fate and movement, and in consideration of socio-economic factors usch as use patterns and cost/benefit analyses. Through this review, the Agency thoroughly studies all relevant implications of potential regulatory activity, from the standpoint of both the pesticide user and the ecology in general. We attempt to ensure that safe and effective alternative pesticides are registered and available when and where they are needed as substitutes for canceled or suspended uses.

This year, the Agency was completed seven substitute chemical reviews. Some of these chemicals may be used as alternatives to DDT, and nay also in the fut ure be called upon to act as substitutes for other canceled substances. Reviews of numerous chemicals as substitutes for aldrin/dieldrin and chlordane/heptachlor are al so currently underway, and are expected to be completed within the next year. Substantial progress is being made in the area of research into substitute chemicals. Prior to EPA's cancellation of DDT and aldrin/dieldrin, and its issuance of Notice of Intent to cancel and suspend chlordane/heptachlor, the Agency made certain that al ternative chemicals were registered for all the discontinued uses, and care- 
fully considered the cost implications of these actions. In the Administrator's DUT Order, for example, a full discussion of the substitute chemicals registered for all uses of DDT, and the costs associated with use of these substitutes, appears on pages 13371-72 and further discussion continues through the remainder of the document. The Federal Register package on aldrin/dieldrin, contains extensive discussion of both substitute materials and the cost impact of suspension. Further comments supporting EPA's position regarding cost and alternatives are included in the U.S. Court of Appeals decision upholding the Agency's suspension of aldrin/dieldrin (a copy of which is also enciosed). EPA's more recent Hotice of Intent to suspend chlordane/heptachlor contains a description of the Agency's position regarding the two factors of cost impact and registered substitutes. The Agency has also prepared a comprehens ive report on the economic impact of the proposed chlordane/heptachlor suspension, and this analys is should be released shortly. I believe that these materials substantially illustrate EPA's consistent efforts to give due consideration to both the cost impact and the existence of registered alternative products, in initiating administrative proceedings against widely used agricultural chenicals.

I would also like to mention the Agency's position on availability of al ternative chemicals, as is discussed on page 34457 of the votice of Intent to suspend chlordanel heptachlor product registrations. The applicable law does not require that the Agency staff, as part of its affirmative case, offer recommendations of substitutes or pro vide evidence that alternatives registered are actually obtainable, efficacious or available at reasonable prices. The Agency is required only to present evidence that alternatives are registered for the uses in question. The burden of demonstrating that the alternatives are not actually obtainable, are not efficacious or are not availatle at reasonable frices remains on the proponents of continued registration of the pesticides under reviel! in a cancellation or sustension proceeding. Thus, the Agency has upheld its legal obligations in the major administrative proceedings 
to date by ensuring that alternative chemicals are registered for the appropriate uses.

While both registered alternatives and economic impacts are important considerations, I believe that the most important consideration of all, which has been the bas is for each of our administrative actions--is, the preservation of human heal th and environmental quality. In order to cancel or suspend a pesticide product's registration, EPA must have substantial scientific evidence indicating that the chemical in question "causes unreasonable adverse effects on the environment," or posses "an imminent hazard" to man or the environment. The cases against continued use of DDT, aldrin/dieldrin, and chlordane/heptachlor are well documented and supported by hard scientific data. See pages 13370-71 of the DDT Order, which contains a discussion of the risks, in terms of health effects and environmental properties, posed by continued use of DDT. At the time of its cancellation, DDT was recoznized as "a nonspecific chemical that kills both target and nontarget species..." It was cited as an uncontrollable durable chemical that persists in aquatic and terrestrial environments, collects in the food chain, and is passed up to higher forms of aquatic and terrestrial life. The persistence and biomagnification of JDT in the food chain were seen as clear causes for concern, given the long-range effects of DUT in man and the environment. Cancer research.experts at that time indicated that the tumorigenic results of tests conducted with DUT to date were indicators of carcinogenicity, and that DDT should be considered a potential carcinogen. At that time, it was also recognized that UDT causes damage to certain wildlife species, particularly avian and aquatic populations.

1 would like to refer to iten 26 on page 37252 and surrounding discussion in the aldrin/dieldrin suspension package, as well as to pages 37245-59) (Conclusions, 1. IV.), and to pages 37267-70 (11. The issue of Carcinogenicity of Aldrin/vieldrin), which contain a full discussion of the evidence presented inuicating that aldrin/ dieldrin pose a high risk of causing cancer in man. Page 34456 (Adiditional Cancer 
Evidence) and the remainder of the enclosed chlordane/heptachlor suspension Notice contains additional discussion of the cancer risks posed by these substances. 1 believe this material thoroughly documents the hazards to human heal th and environmental well being posed by aldrin/dieldrin and chlordane/heptachlor.

EPA's administrative actions against pesticide product registrations are initiated on the basis of scientific data, but are finalized upon a complete weighing of the risks and benefits which can be expected from continuing use of the material in question. Extensive risk-benefit discussions appear in the enclosed material on UDT, aldrin/dieldrin and chlordane/heptachlor. In the first two cases, determination was finally reached that the risks of continued use of DDT and aldrin/dieldrin outweighed the benefits they afforded. As the U.S. Court of Appeals stated in its review of EPA's aldrin/dieldrin suspension, "the statute places a heavy burden on any administrative officer to explain the basis for his decision to permit the continued use of a chemical known to produce cancer in experimental animals." The cancer risk posed by these pesticides has been found to outweigh almost all of their benefits. You may be interested to know that EPA recently submitted a report to congress on UDT. The study concluded that DDT residues in the food supply, human tissues and in the environment have declined in recent years, especially since the 1972 cancellation. It showed that risks are declining, alternative pesticides are available, and economic impacts have been nominal since our 1972 action. For most crops, in-cluding cotton, production has been maintained. However costs have increased in some cases. In reviewing studies conducted since 1972, the report found that DDT should still be considered a potential human cancer agent; that DDT is stored in human fatty tissue, wildlife and fish; that DDT is toxic to fish and birds and interferes with the reporduction of some species; and that DDT persists in soil and water for years.

Finally, I would like to as sure you that EPA is vitally concerned, in a!l its 
policy and regulatory decisions, with maintaining a balance between effective pest control and environmental quality. Jur programs are mandated by Congressional statute, and can be revised at the discretion of the Congress at any time they consider necessary or appropriate. EPA must consider the issues of human carcinogenicity, wildlife species preservation, and overall environmental integrity, in judging the Agency's pesticide regulatory actions. EPA believes in the legacy of sound, health, plentiful nationa! and world environment for future generations. 
2: Did you hear Alvin Young's talk yesterday about the disposal of agent orange?

A: No, I did not.

2: Are you aquainted with the problems that the Air Force has had of disposing of agent orange?

A: Yes, $1 \mathrm{am}$.

What comments do you have?

A: Agent orange, the recovery of useful valuable pesticide in a disposal situation must be determined to be unfeasible before destruction can be considered. The possibility of recovering useful herbicide of $2,4-D$ and $2,4,5-T$ components of herbicide orange with the concurrent destruction of contaminant dioxin, appear promising, therefore, this avenue must be fully explored before a decision can be made on destruction of $2,4-D$ and $2,4,5-T$.

With respect to destruction by incineration at sea, the Environmental Protection Agency feels satisfied that there is little likelihood of release of unburned herbicide orange or its contaminant, dioxin, into the environment. With a waste of similar chemical nature, but a lower caloric content, destruction efficiency of up to $99.99 \%$ have been achieved and never less than $99.0 \%$. EPA is presently reviewing the Air Force's application to burn orange at sea and we expect to make a statement on that about next week.

Q: Monitoring program for dioxin is a short-term sample program which cons ists of the beef and what was the long-term monitoring program or is there one currently in operation?

A: The long-term one is to look at gestation periods, still births, other kinds of things that may happen to the animal itself, there may not be one, there might not be a long-term program.

0: Oh, so I see, the long-term-program really will depend upon what the beef sampling program finds?

A: Yes. What they're doing in Oklahoma, as most of you know, most of oklahoma since 1953 has had a lot of applications in 2,4,5-T. They picked some ranches there and this wasn't easy to do either, to find a rancher who'd let us makr a cow that was sprayed with 2,4,5-T last spring and follow that cow to market and all the way to the processing plant and take a sample. Many of the ranchers just don't like to have EPA guys on their farm or ranch and maybejustifiably so. It was not easy to get the 125 samples, but they were collected, they were froze immediately, and were sent to laboratories in Sal't Lake City, Midland Michigan, our labs in the south and a fourth lab as a control. I say again the results should be out, we should have a decision by Thanksgiving whether or not Mr. Train wants to open up the hearings again on 2,4,5-T or whether some other adverse action will be taken.

Q: Being as you are so concerned about DDT being a carcinogenic, why isn't tobacco taken off the market?

A: My wife asks me that every night. 
Q: It's the same difference, I mean it's dangerous, tobacco has been proven more dangerous than DDT ever. thought of being, but EPA hasn't done anything with it. I think it's politics myself.

A: I disagree with that. I think that DDT has proven to... Well, we know what DDT can do.

Q: I don't see any information that shows this. Where is the statistical information at?

A: For DDT?

Q: Yes

A: It's in the Federal Register.

Q: Why has it never been put out to the public?

A: The Federal Register is public property. It's in all public libraries, all state offices, all Federal offices and all county offices.

$\checkmark$ : lias DDT been shown to be carcinogenic to human beings?

A: I'm not going to argue about that fact. Llow about al cohol?

2: Has Mr. Train made any decision regarding sodium cyanide and the $49-44$ ?

A: I think this afternoon you have a speaker on the subject, I'll leave it to him.

0: About your admin istrative law, has Mr. Train made a decision?

A: He will make it today. Today is Hednesday isn't it? On strychnine, it's been used on rabid skunks under section 16 in Hyoming and also, 1 don't know whether Montana has applied or not. They've issued a permit to Wyoming to use strychnine. The Communicable Disease Center in Atlanta, Georgia has applied for a permit for strychnine and 1 believe EPA is going to authorize that one. 1 think the Agency is going about these requests at a reasonable, sensible, professional manner, based on information that they have.

1: May 1 ask a question about strychnine? CDC in Atlanta and the state of Hontana have applications for registration in. We just received our application back, denied. But in the Federal Register of September 12, 1975, both CDC and iion tana applications are discussed there in regard that they are going to allow everybody to comment and maybe they will hold hearings to possibly change the 72-2 order to allow for registration consideration. In other words, the same process as sodium cyanide. Is that what you foresee?

A: Yes, that's what I see.

Q: In other words, this is a longevity paper work process again, with attornies and everything wrapped up in trying to get a job done, what do we do in the interim?

A: Be patient, every process back there is a long drawn out legal process and when Train said he has asked for a committee to study ways and means to improve the decision making process in the office of pesticides, he means that. 
2: I just want to comment about one of these proposed amendments for the information of the people in this room. For self-certification, under Montana's Pesticide Act, we cannot self-certify private applicators, they will still be certified by written examination not by signing a register as proposed. Even if this amendment is adopted by Congress, that will not change state law within Montana and our law requires a certification of private applicators by written exam. This will not change other states who have already implemented certain provisions such as New York, etc.

A: The three of the $\$ 5,000,000$ that we transferred to the extension service to develop the manual, the training, etc., etc., that job is just about completed. If this amendment passes, a lot of money is going down the drain, and Minnesota won' $t$ buy it either and neither will Texas, 1 don't know about Wyoming.

2: Let me ask a question that I think that's pretty important and that is the cancer policy of EPA. I think this creates a lot of confusion in the minds of a lot of people, simply because they have gone away from the use of the carcinogenic term to the oncogenic term and $I$ think this is creating a situation that we are not going to be able to live with. Can you comment on that policy?

A: You are one of the several professionals that has asked that question. This is another item that Russ has met on about eleven days ago, is our cancer policy. within EPA. He expects to announce a cancer determination policy within, I would say two weeks, of a way to go about it. It will be somewhat different, 1 think, than the way we have done it before.

2: It's going to stall any pesticide development, 1 am sure until it's cleared up. Because no company is going to invest millions of dollars to find out somewhere down the road he can create a tumor by overfeeding the product to the test animal that is especially subceptible to that particular situation anyway.

$A$ : This is the first time I really ever had a chance to watch Russ produce. I'm impressed with his desire to learn more about the effects of pesticides on people and the environment. I think in the next two nonths you are going to see some changes, I think, you are going to see a different way of doing business in the office of pesticides. If it doesn't happen, I think Congress is going to do something about it. 

EFFECTS OF SAGEBRUSH COITTRL ON WILDLIFE AIID

ECOSYSTEM COMPONENTS - RESULTS OF A

TEII YEAR STUDY

\section{IIITRODUCTIO:I}

Plant communities containing sagebrush are common and often a dominating aspect of Montana's prairies and mountain foothills. Sagebrush ecosystems are necessary for the very survival of some wildlife species and important to many others. Because of its broad distribution and general importance to wildlife (Quimby 1966) it was not surprising that game managers were among the first to express their concern about the chemical war being waged against sagebrush.

By the early 1960 's the practice of treating sagebrush rangelands to eridicate sagebrush and increase grass and livestock production was becoming widespread and the potential negative impact on Montana's wildlife resource was significant. Public land managers were also becoming aware of and concerned about the increasing demands for multiple use of public lands. In 1965 concern was broad-based, culminating in the initiation of a joint, ten year commitment by the Montana Department of Fish and Game and the Bureau of Land Management to study the ecology of sagebrush control. All field work for this cen year project has now been completed and final reports are in preparation. Vast quantities of data were gathered and have been reported in more than 2,000 pages of annual progress reports, popular and technical articles, conference and workshop presentations, etc.

The primary objective of the project was to determine the effects, if any, on certain non-target ecosystem components of a control program aimed at reducing or eliminating sagebrush from central Montana rangelands. Ecosystems are complicated

Presented by Eugene 0. A Tl en, Chief, Research Section, Montana Department of Fish and Game, Bozeman, Montana 
and often delicate structures and it is very difficult to determine the role played by a major component such as sagebrush. Yet, to recognize the full impact of sagebrush removal, myriad sagebrush-ecosystem component relationships must not only be unveiled, but understood. Many of these relationships can be observed and measured directly; others can only be surmised through subtle and intuitive deduction. Therefore, proper evaluation of sagebrush control dictated a variety of ecological studies of associated ecosystem components.

During the course of this project, data evaluation was complicated by an omn ipresent factor - the grazing of domestic livestock. Sagebrush control is often the first of several events associated with the refinement or altering of an existing grazing management system, including: water developments, fences, changes in grazing seasons and intensities of use, etc. In this study, the presence and impact of grazing animals often seriously influenced the data gathered and their subsequent analysis-sometimes actually overriding and masking the effects of sagebrush control itself.

With these factors as background, I would like to briefly outline the nature of the study and summarize the major findings.

\section{DESCRIPTION OF THE STUOY AREA}

Most work was conducted in the Yellow Water Triangle which lies in east-central Montana between U. S. Highway 87 and Montana Highways 200 and 244 and between the towns of Winnett and Grassrange; some studies were conducted in a smaller area in the Missouri Breaks north of the Yellow Water Triangle. Jorgensen (1974) described in detail the physiography, geology and soils, climate and vegetation of the study area.

\section{METHODS}

Five areas were selected for treatment and intensive study (Table 1). Treatments were applied to Yellow Water Triangle study areas in 1968 wille the ilissouri ureaks area was treated in 1972. Chemical treatments were with 2,4-D and included total 
and partial kill blocks and 100 foot wide strips; mechanical treatments included contour furrowing and interseeding. Percent kill of sagebrush on total kill blocks and strips were approximately 95 while percent kill on partial kill blocks averaged 59 and ranged from $0-30$ for partial kill strips.

Table 1. Spray Treatment Data.

\begin{tabular}{|c|c|c|c|c|}
\hline Area & Treatment & When Treated & $\begin{array}{l}\text { Anount } \\
\text { Treated }\end{array}$ & $\begin{array}{l}\text { Percent dead } \\
\text { sagebrush after } \\
\text { treatment }\end{array}$ \\
\hline \multirow[t]{2}{*}{ Winnett } & Total kill & June 1968 & 480 acres & $95+$ \\
\hline & Strip spray & & 400 acres $^{2}$ & $95+$ \\
\hline King & Total kill & June 1968 & 229 acres & $99+$ \\
\hline Sibbert & Partial kill & June 1968 & 253 acres & 45 \\
\hline \multirow[t]{2}{*}{ Iverson } & Partial kill & June 1963 & 317 acres & 59 \\
\hline & Strip spray & & 320 acres $^{2}$ & $0-90$ \\
\hline $\begin{array}{l}\text { Missouri } \\
\text { Breaks }\end{array}$ & Total kill & May 1972 & 320 acres & $99+$ \\
\hline \multicolumn{5}{|c|}{ 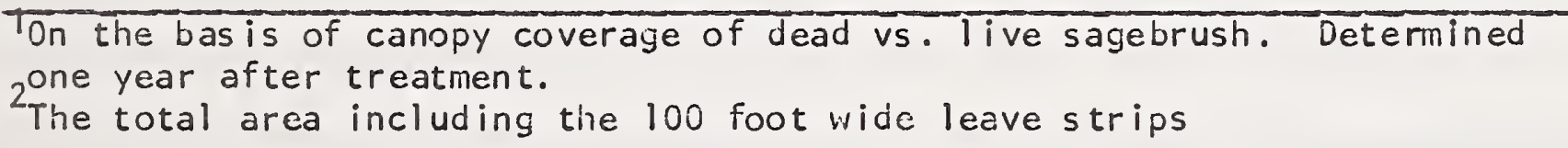 } \\
\hline
\end{tabular}

A wide variety of methods and techniques were necessary to collect data during the many project phases; they have been reported in detail in the ten annual progress reports (see Literature Cited).

RESULTS

Soil

Two parameters of soil were evaluated with respect to chemical and mechanical treatments: soil erosion and soil moisture.

Three hundred erosion disks were installed on the Winnett, King and Iverson study area. Comparisons of soil erosion were made between sprayed and unsprayed 
sites, between mechanically treated and control sites, and between sites protected from grazing and unprotected sites.

Steepness of slope was the most important factor contributing to soil erosion; however, no difference in rate of soil erosion was detected between any treated and untreated plot; this was true both inside and outside exclosures (Jorgensen 1974 ).

Effects of treatments on soil moisture were evaluated using the gypsum block method and is described in detail in Jorgensen (1975). Results indicate that total kill spray did not significantly effect the degree of soil moisture recharge following spring snowmelt and heavy rainstorms. Killing of sagebrush apparently did not affect rate of water penetration into this type of soil (thebo clay!.

The first two years following treatment, moisture withdrawal was greater on the unsprayed site compared to the sprayed site at all depths except four feet; the third year the rate of withdrawal was greater on the unsprayed site at all depths.

Total kill spraying did not affect the amount of snow accumulation during the years of study, but on wind-blown ranges snow accumulation and resultant soil mo isture recharge could decrease as the dead sagebrush snags break down.

On the partial kill spray study area, soil moisture recharge was greater at the $36^{\prime \prime}$ and $48^{\prime \prime}$ depth on the treated sites than on the untreated. liowever, no significant differences in moisture withdrawal resulting from partial kill spray were detected on any site in any year. It is unclear why the effects of partial kill were different from those of total kill.

In this study, no increases in soil moisture following mechanical treatments were detected. The effectiveness of contour furrowing in improving soil moisture is dependent upon the decrease of runoff. During the study period, little or no runoff was observed in the control area.

\section{VEGETATION}

Following treatments vegetation was measured with respect to canopy coverage (CC), dry matter production, fol iage height, species composition and succulence; 
results were reported by Jorgensen, 1975. Differences in effects of partial kill compared to total kill spray were ones of degree, with effects of partial kill less pronounced or persistent. than those of total kill.

\section{Forbs}

One of the greatest effects of total kill spray was the large reduction in CC of forbs. Total CC was reduced to about $1 / 4$ that of the controls immediately after treatment and had only recovered to approximately $1 / 2$ the controls five years posttreatment. llost forbs were reduced following total kill spray, but subsequent rates of recovery varied between species. Six years post-treatment, CC of fringed sage (ARFR) on treated areas was equal to or greater than controls, while vetch (VIAM) showed little or no recovery. Dry matter production of vetch was about five times less on sprayed plots while production of fringed sage was three times greater. Yellow sweetclover (MEOF) is highly susceptible to 2,4-D damage, but apparently recovers rapidly. In the :lissouri Breaks study area, sweetclover was virtually absent on the sprayed site one year following treatment as compared to its abundance on surrounding unsprayed sites; one year later the situation was reversed.

Three forbs were analyzed for succulence six years post-treatment. Ho significant differences were noted for dandelion (TAOF); succulance of fringed sage and vetch was significantly less on the sprayed plots than on the controls.

\section{Grass}

Increased dry matter production of ilestern wheatgrass (AGSM) was evident one year following total ki!l spray treatment, ranging from 1.13 to 3.16 times that of the controls. In the Artemisia-Agropyron type where bluebunch wheatgrass was the dominant grass, its production was 2.0 to 3.36 times higher on sprayed plots. Production of both grasses continued to be 2.0 to 3.0 times greater six years posttreatment. Other grasses, as a group, had a higher yield imrediately after spraying averaging 1.6 times that of control; three years post-treatment, however, their production on sprayed plots was equal to or less than the controls. 


\section{lecinanical Treatments}

Total CC of the vegetation community was significantly decreased following mechanical treatment while amount of bare yround increased; both changes persisted five years post-treatment. Treatment-induced increase in bare ground was attributed to sharp decreases in CC of blue grama (BOGR), lichens and clubmoss (SEDE).

One year following treatment, CC of grass was significantly lower on the treated plots, but eventually increased to about the same as the controls. Most of the increase in CC of grass was attributed to western wheatgrass, but its increase was apparently only enough to offset decreases experienced by blue grama and needle-andthread (STCO2).

Canopy coverage of forbs and shrubs (mainly big sagebrush) were unaffected by mechanical treatment. Succulence of fringed sage and vetch was significantly lower on the contour furrowed plots than on the controls six years post-treatment; dandelion was not affected.

\section{SAGE GROUSE}

Habitat requirements of sage grouse are well documented, and game biologists have long recognized the close tie between sage grouse and their sagebrush environment. Because sagebrush control may not have an immediate ncticeable affect on sage grouse (depending on size of area treated in relation to total habitat available), it was difficult to evaluate the effect of sinall (less than 500 acres) scattered ( 3 areas in 171,000 acres) control sites in our study. Movements and habitat use of individuals and groups of birds were determined, but translating these data into population consequences required a certain amount of inference as well as direct obs ervation.

\section{Direct observation}

Dropping counts - Dropping counts were made along 257 permanently located transects on four study areas for five years ( 3 pre- and 2 post-treatment) (Pyrah 1972). Results indicated a 32 to 38 percent reduction in sage grouse use in the total kill 
block and strip spray areas, respectively; mechanical treatnents resulted in a 56 percent decline. Slock partial kill declined slightly tie first year, but in two more years was inack to pre-treatment levels while use of partial kill strips doubled. Because sage grouse populations during this time more than doubled in this general area, effects of partial kill may have caused a decline in the block and no effect in the strip treatments, respectively.

Strutting ground counts - Between 1963 and 1269 counts from grounds adjacent to treatment areas declined slightly ( 6 percent) while other grounds in the Triangle doubled and tripled in cock counts (ave. 264 percent). A 31 percent loss of habitat (sprayed) adjacent to the ivorth $\gamma_{\text {e }} l$ low water strutting ground was apparently responsible for a 63 percent decline in the number of strutting males over a two year period.

\section{Inference}

Data on sage grouse habitat relationships were obtained from observations of 73 radio-marked tirds. Food habits were determined by examination of 426 crops collected during all seasons.

Breeding llabitat

Nallestad and Schladweiler (1974) reported 80 percent of locations of breeding cocks away from strutting grounds occurred in sagebrush stands with a canopy coverage of 20 to 50 percent. Ho cocks were observed in areas having less than 10 percent CC of sagetrush.

All 41 sage grouse riests located by Wallestad and Pyrah (1974) occurred under sagebrush plants and were located in stands of sagebrush averaging 25 percent CC. They found that successful nests inad significantly greater sagebrush cover within 24 inches of the nest, within a $100 \mathrm{sq}$. ft. plot around the nest and were located in stands of sagebrush with a higher average CC than those of unsuccessful nests. urood Habitat

Brood habitat was largely determined by the availability of succulent vegetation (Peterson 1970). Broods used sagebrush areas early in summer and then shifted to 
bottomland types as uplands dessicated. In fall, as green forbs dried, sage grouse shifted back to sagebrush types for food and cover. Sagebrush canopy measured at brood sites averaged 14 percent for June, 12 percent for July, 10 percent for August and 21 percent for September (ivallestad 1971).

\section{Fall and Winter Habitat}

Seventy-eight percent of 151 fall and winter locations of sage grouse recorded by Wallestad (1972) occurred in sagebrush stands that exceeded 20 percent CC. Eng and Schladweiler (1972) reported 82 percent of 60 winter locations occurred in stands of sagebrush that exceeded 20 percent CC. They described sage grouse wintering areas as being large expanses of sagebrush (20 percent and greater CC) on land having little if any slope. When snow depth exceeded 12 inches sage grouse were restricted to taller sagebrush stands on about 1700 acres, or only seven percent of the range available to them in a normal winter (Wallestad 1973).

Food Habits

Sagebrush comprised 62 percent of all foods consuried by adult sage grouse during the year and in winter (December - February) sagebrush was the only item eaten (Wallestad et al. 1975). Only through the months of June - September did sagebrush make up less than 60 percent of the diet by volume. Peterson (1970) reported that sagebrush became an important part of the diet of juvenile sage grouse when they were 12 weeks of age.

Depending upon the size of area treated and the type of treatment, effects of sagebrush control on sage grouse can apparently range from no noticeable effects to near extinction. Most sagebrush control projects are aimed at dense stands of sagebrush in excess of 20 percent CC. Stands of this density comprise the sage grouse wintering-nesting complex, and the potential for a severe negative impact is great. Those treatments doing the least damage to the sagebrush stand likewise affected sage grouse the least and the duration of the adverse effect was shortest. Studies indicated that strip spraying was a desirable alternative to block spraying and that 
partial kill was superior to total kill.

Antelope

As with sage grouse, a certain amount of inference must be employed when attempting to evaluate the full impact of sagebrush control on antelope populations. Eleven separate studies of antelope food habits in central and eastern Montana indicate that big sagebrush is the most important winter food and occurs in the year-around diet more than any other item (Couey 1946, Cole 1956, Cole and Wilkins 1958, Martinka 1967 , Wentland 1968, Bayless 1970, Campbe 11 1970, Roberts 1970, Becker 1971, Freeman 1971, and inapp 1375). Some of these studies also found forbs to be the primary springearly summar food when available. A study of 35 antelope fawn bedding sites in central Montana indicated an importance of sagebrush in the selection of bedding sites (Pyrah 1974).

\section{Total Kill Spray}

Antelope avoided total kill spray area, resulting in a corresponding increase in densities on the untreated portions of summer and winter ranges - they did not expand or establish new sumer or winter range areas. Total kill spray adversely affected antelope food and cover requirements by nearly eliminating sagebrush and by reducing the amount of forbs and changing their composition. The non-use of total kill spray areas has not changed seven years post-treatment.

\section{Partial Kill Spray}

Vegetation changes resulting from partial kill spray were not as damaging to antelope food and cover plants as was achieved with total kill. While antelope avoided sprayed areas the first years foliowing treatment, observations five years post-treatment indicated suitable conditions for antelope had been restored, but possibly not to pre-treatment levels. As with total kill, antelope densities increased on the untreated portions of their range - they did not establish new summer or winter range areas. 


\section{Mechanical Treatments}

Contour furrowing had a severe adverse impact on antelope, causing them to make little use of the area in the seven years since treatment. Fecause this treatment resulted in few vegetation changes, avoidance by antelope was probably related to security and difficulty for escape caused by the uneven ground. As with spray treatments, antelope densities increased with no expansion of traditional summer or winter ranges .

Antelope use of interseeded areas following treatment was near normal.

The two most damaging treatments to antelope (total kill spray and contour furrowing) were both used on the King study area. This area was part of the home range of antelope herd 11 . Doe band II-A was most directly influenced by the treatments and experienced significantly lower fawn production after treatment than the rest of heard 11 and was sub-standard to the Yellow Water Triangle as a whole (Pyrah 1975). This decline in production was apparently an inverse density dependent response caused by antelope non-use of treated areas and the subsequent increase in densities in the remaining untreated portion of their traditional range.

As with the sage grouse, partial strip, partial block, total kill and contour furrowing treatments had increasing adverse effects on antelope use of treated areas. Mule Deer

Reduction of big sagebrush and forbs following treatment with 2,4-D has been vell documented. Mackie (1970) reported that big sagebrush formed an important part of the Missouri Breaks mule deer diet during winter and spring and that forbs were significant during all seasons. This study was initiated on the Missouri Breaks study area in 1970 to investigate the effects of total kill spray on mule deer range use patterns. Range use patterns were determined by pellet group counts pre- and post-treatment and was reported by Becker and Wallestad (1974). 
Range use patterns of mule deer changed significantly following treatment. Pretreatment pellet counts in 1970 and 1972 indicated similar use of both portions of the study area (Table 2). One year following treatment, 55 percent of the control sample plots contained pellet groups while only 5 percent of the sample points in the treated area contained pellet groups. In the control, mean pellet groups per sample point increased from 0.50 and 0.45 pre-treatment to 2.15 post-treatment; in the treated area, mean groups decreased from 0.43 and 0.71 to 0.10 , respectively. Mackie (1970) described eight different habitat types in the Missouri River Breaks and reported the Artemisia-Agropyron type to be important to mule deer during winter when sagebrush was the most important food. Results of this study, in conjunction with the findings of Mackie, indicate that large-scale alterations of this habitat type would significantly lower the area's potential for supporting mule deer and could result in a population decline. 
TABLE 2. OCCURRENCE OF MULE DEER PELLET GROUPS BY YEARS AND TREATMENT TYPES.

Treatment Types $\frac{\text { Pre-treatment }}{1970} \quad \frac{\text { Post-treatment }}{1972}$

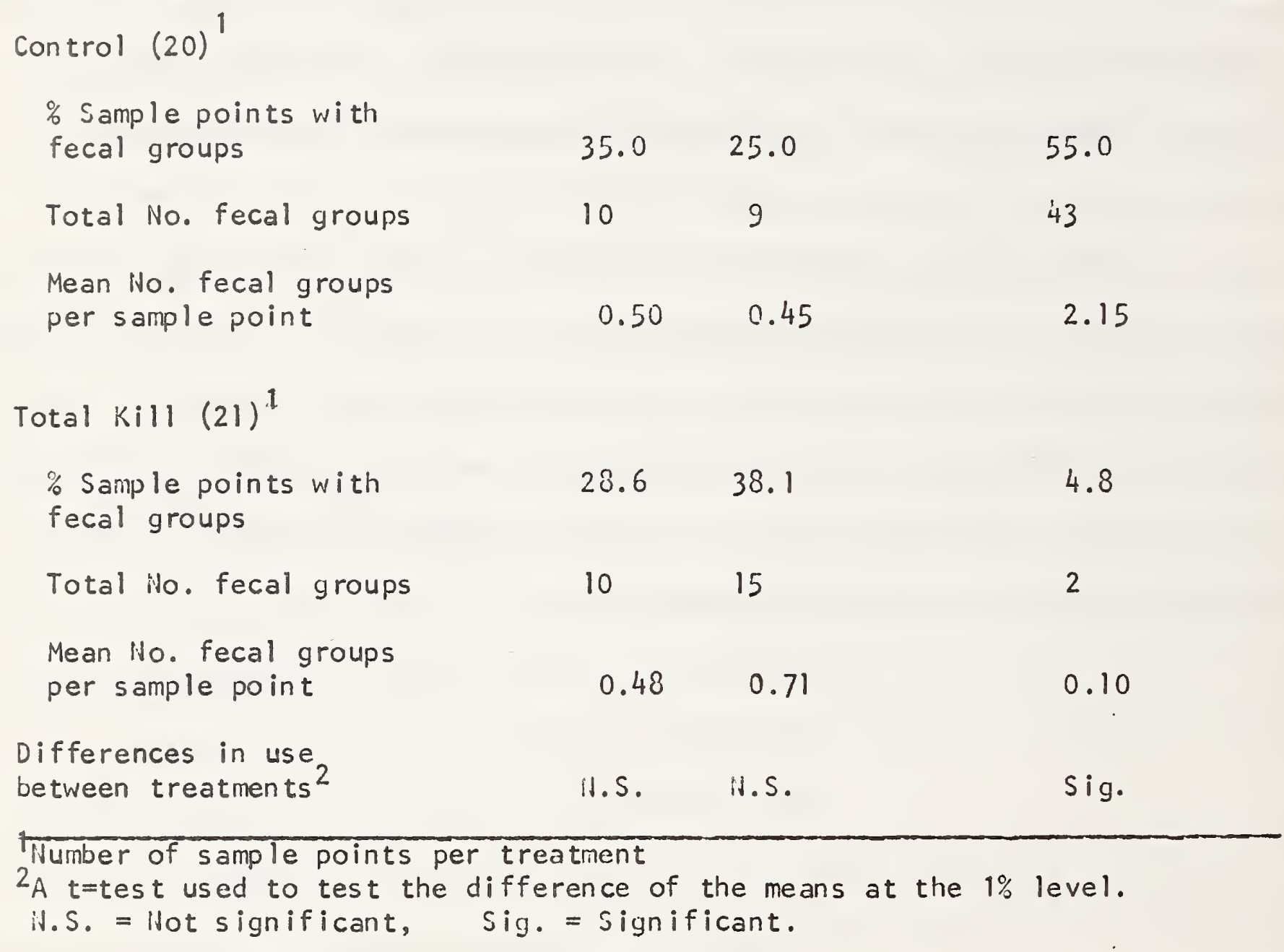




\section{Small Mammals}

Studies were initiated in 1966 to determine the effects of partial kill block spray (Iverson study area) and total kill block and strip spray (Winnett study area) treatments on small mammal populations. Results have been reported by Cada (1968), Tschache (1970) and Reichelt (1974).

The most commonly captured small mammal was the dear mouse (Permyscus maniculatus); 10 other species were rapresented. Because of normal fluctuations in population levels, numbers of deer mice can be compared within years, but not between years. The 1973 trapping series produced much higher numbers of deer mice than any of the previous four trapping studies (Table 3). The population density may actually have been greater or an "apparent" greater density may have been due to the different method of handling the trapped mice (Reichelt 1974).

No differences in mouse densities were noted one year following treatment. After five years, however, deer mice had been nearly eliminated from the total kill area. While an increase in deer mouse density was indicated in the strip spray area, most (57 or 72) mice were caught in the live sagebrush strips. There reductions were probably in response to changes in vegetation composition which were most dramatic in total kill plots. Reduction in deer mouse numbers were not compensated for by subsequent increases in numbers of other species. The apparent increase in the strip apray area may have been the result of increased "edge effect."

Since the deer mouse is an important component in the food chain of other animals, the overall importance of its reduction may not be easily or immediately recognized. 
TABLE 3. NUMBER OF DEER MICE CAPTURED.

\begin{tabular}{|c|c|c|c|c|c|}
\hline \multirow{2}{*}{ I verson Study Area } & \multicolumn{3}{|c|}{ Pre-treafment } & \multicolumn{2}{|c|}{ Post-treatment } \\
\hline & & & & & \\
\hline Partial Kill & $13.9^{3}$ & 6.5 & 33.0 & 9.3 & 69.0 \\
\hline Control & 11.2 & 2.3 & 31.2 & 9.4 & 66.0 \\
\hline Winnett Study Are & & & & & \\
\hline Control & 13.0 & 5.6 & 23.3 & 10.2 & 27.0 \\
\hline Total Kill & 15.3 & 3.4 & 25.6 & 10.3 & $6.0 *$ \\
\hline Strip Spray & 8.4 & 6.0 & 27.0 & 5.6 & $72.0 *$ \\
\hline
\end{tabular}

*Significant difference $(P<0.015)$ from catch on Control Plot.

${ }_{2}^{1}$ Cada (1968).

2 Tschache (1970).
3 Individuals per 18.6 acres.

Non-game 3 irds

Studies on the effects of sagebrush control on small, non-game birds were initiated in 1966 and results have been reported by Feist (1968), Best (1970) and Reichelt (1974). Partial kill block spray was evaluated on the Inverson study area and total kill block and strip spray was evaluated on the Winnett study area.

Eight different species of small birds were observed; Brewer's and vesper sparrows were the most abundant and composed nearly 90 percent of all birds observed prior to treatment (Table 4). One year following treatment, total birds observed on the total ki 11 block spray had declined and by five years post-treatment had declined to approximately one-half that of the control. This reduction in total birds was attributed to the reduction and near elimination one and five years post-treatment, respectively, of the Brewer's sparrow. Total kill block spray was apparently the only treatment detrimental to small bird populations and the Brewer's sparrow appeared to be the only 
species adversely effected.

TABLE 4. NON-GAME BIROS OBSERVED DURING FIVE BREEDING SEASONS.

\section{IVERSO'A STUOY AREA \\ Control Plot \\ Brewer's sparrow \\ Vesper sparrow \\ 0 ther \\ Total}

Partial Kill Plot Brewer's sparrow Vesper sparrow 0 ther

Total

WINIETT STUDY AREA

Control plot

Brewer's sparrow

Vesper'sparrow

0 ther

Total

Strip Spray Plot Brewer's sparrow

Vesper sparrow

other

Total

Total Kill Plot

Brewer's sparrow

Vesper sparrow

0 ther

Total

$\begin{array}{lccll}\frac{1966^{1}}{50(55)^{3}} & \frac{1967^{1}}{44(64)} & 1963^{2} & 1969^{2} & 1973 \\ 24(27) & 23(33) & 20(29) & 14(21) & 12(29) \\ 16(18) & 2(3) & 6(8) & 13(19) & 14(33) \\ 90(100) & 69(100) & 70(100) & 68(100) & 42(100)\end{array}$

\section{$55(61)$}

$24(27)$

$11(12)$

$90(100)$

$29(62)$
$16(34)$
$2(4)$
$47(100)$

$34(60)$

$21(36)$

$2(4)$

$31(50)$

$17(43)$

$26(42)$

$5(8)$

$57(100)$

$62(100)$

$11(28)$

$12(29)$

40(100)

Feist (1968).

2 Best (1970).

3 Individuals per 40 acre plot (Percent of total plot observations).

*Significantly different $(P \quad 0.05)$ fron count on Control Plot.

$\begin{array}{cccll}40(43) & 56(59) & 39(53) & 39(54) & 33(56) \\ 46(49) & 29(31) & 27(37) & 23(32) & 12(20) \\ 7(8) & 9(10) & 7(10) & 10(14) & 14(22) \\ 93(100) & 94(100) & 73(100) & 72(100) & 59(100)\end{array}$

$\begin{array}{ccccl}46(55) & 41(69) & 38(56) & 34(56) & 29(50) \\ 34(41) & 16(27) & 26(37) q & 22(36) & 14(24) \\ 4(4) & 2(4) & 6(7) & 5(8) & 15(26) \\ 84(100) & 59(100) & 70(100) & 61(100) & 58(100)\end{array}$

$\begin{array}{ccccc}15(28) & 38(54) & 27(45) & 11(27) & 1(3) * \\ 35(64) & 29(40) & 29(48) & 24(59) & 16(55) \\ 4(8) & 4(6) & 4(7) & 6(14) & 12(42) \\ 54(100) & 71(100) & 60(100) & 41(100) & 29(100) *\end{array}$

The Brewer's sparrow nests above the ground and Best (1970) concluded that the reason for its decline one year post-treatment was due to a reduction of suitable nesting cover. He stated that it compensated for the lack of protective foliage by selecting larger, more heavily branched dead shrubs. As sagebrush skeletons 
deteriorate, an area would become increasingly unsuitable for nesting by Brewer's sparrow.

The vesper sparrow nests on the ground, usually under the protection of sagebrush or another brush; it appeared to ve less affected as Iong as there was some protection provided by the dead sagebrush skeleton. The vesper sparrow population may also decline as the dead sagebrush deteriorates. 


\section{GRASSHOPPERS}

Effects of total kill spray and mechanical treatments on grasshoppers was studied by Hewitt and Rees (1974) on the Winnett and King study areas during 1969-1971. They concluded (from Table 5):

1) Spraying for sagebrush control with 2,4-D did not result in a large reduction in the density of grasshoppers. Some species such as Psoloessa delicatula de licatula were consistently less abundant on treated areas; other species such as Arphia conspersa and Arphia eseudonietana were more abundant.

2) Plots which were contour furrowed and interseeded provided an unfavorable habitat for most grasshopper species present, including all the economically important species indicated in Table 5, except the migratory grasshopper. Grasshopper density was less during all three years of sampling on treated plots. The greatest differences were found on contour furrowed plots, but these differences appeared to decrease with time. One species, Psoloessa delicatula delicatula, was much less abundant on these treated plots, but other species, such as Arphia conspersa and Trimerotropis gracil is sordida, were more abundant.

3) Probably both increases and decreases in preferred food plants of grasshoppers that resulted from treatments influenced the abundance of grasshoppers. However, abundance on treated and untreated plots could only be related to food plants in a general way.

It also appeared that mechanical treatments were more detrimental to grasshoppers that winter as nymphs compared to those hatching from eggs in the spring. 
TABLE 5. THE PERCENTAGE CHAIGE IIN GRASSHOPPER SPECIES OVER A 3-YEAR PERIOD DUE TO RANGELAND RENOVATION TREATMEINTS. 1

\section{Species $^{2}$}

1. Aeropedellus clavatus (Thomas)

2. :Ageneotettix deorum (scudder)

3. Arphia conspersa (scudder)

4. A. Eseudonietana (Thomas)

5. ثncoptolophus sordidus costalis (Scudder)

6. $\frac{\text { *Eritett ix simplex tricarinatus }}{\text { (Thomas) }}$

7. Melanoplus gladstoni (Scudder)

8. *M. infantilis (scudder)

9. *M. sanguinipes (F.)

10. 20peia obscura (Thomas)

11. $\frac{\text { *Ph l ibost roma quadrimaculatum }}{\text { (Thomas) }}$

12. Psoloessa del icatula del icatula

13. Irachyrhacinys kiowa (Thorias)

14. Trimerotropis campestris

15. I. gracilis sordida (balker)

16. Xanthippus corallipes Luckelli

Miscellaneous species

Total

$$
\frac{2,4-0}{\text { Vinnett }}
$$

$\frac{\text { Furrowed }}{\text { King }}$

$\begin{array}{lll}-39.5+50.0 & -20.0 \\ -41.2+4.5 & -78.3 \\ +40.0+100.0 & +66.7 \\ +76.9+160.0 & +40.0\end{array}$

$-6.8+60.0-100.0$

$\begin{array}{lll}-74.4 & +181.8 & -61.5\end{array}$

$-75.0+57.1 \quad-25.0$

$+55.6-23.3 \quad-70.3$

$-3.8-14.0+28.6$

$+33.3+73.1-91.3$

$+\quad-64.7 \quad-50.0$

$+6.7-29.1 \quad-88.7$

$+125.0-65.6 \quad-95.9$

$\begin{array}{lll}-74.5 & -87.5 & -62.5\end{array}$

$-50.0+75.0+75.0$

$-43.9+30.0-13.5$

$-50.1+11.5-57.8$

$\begin{array}{lll}-22.3-12.8 & -60.5\end{array}$

$1+$ and - refers to percent increase and decreasc due to treatinent.

2 * Economically important species on ránigeland. 


\section{LIVESTOCK}

fis was previously mentioned, livestoch grazing was a significalit influence through out the study. Data were gatiered to deterni ne cattle food and range use haibits anci to iclp evaluate data yatiered from other piasus of tile study. These data are currently veing analyzed and some gereral conclusions can we drawn (Pyrah 1975).

Forbs and shrubs occasionally appeared to be preferred forage. Yellovi sweet clover was used exclusively when it was availaile, and jreasevood and silver sagebrusi was used late sunmer and early fall after grasses had desiccated.

Fond ahundance or plant composition do not appear to be the inst important factors yoverning how cattle vill use a pasture. Factors wich may be more imporcant are water source, fence placement and social tradition. Cattle did not always appear to avoid areas simply because of the presence of sagelrush, nor did use of an area appear to increase simply because sagebrush had been removed.

On strip sprayed areas no difference in use could be detected between the sprayed and unsprayed strips. On the total kill Llock spray, data were conflicting tecause of new fences and later sources and disruftion of traditional use patterns. On the king Study frea it was indicated that contcur furroving was less desirable than total kill. There has evidence this choice may have been related to greater forb abundance and/or comilosition on interseeded areas.

Further data analysis may help clarify cattle range relationships and help put in proper perspective their role in the ecology of other ecosysten components.

\section{DISCUSSIOH}

The sudden death of a major dorninant species in a plant comunity sets off a chain of events that ultinately effects every component of the ecosysten. Some of tirese events are well understood, some are suspected, to exist, but probably many are unknown. Most studies following heruicide and mechanical treatments have Leen empirical in nature, measuring the gross changes in vegetation, but not attempting to determine the underlying intermediate events responsible for these changes. 
Until the basic chain of events following treatnents are understood, results of studies in one habitat type cannot be safely extrapolated to others.

The prime objective of sagebrush control programs is to increase grass and livestock production. Results of such prograns are vieved as beneficial or detrimental depending on how changes effect various facets of human society. Seldom are changes evaluated as to what is "good" or "bad" for the plant commity itself. Sagebrush is a climax plant in many of the prairie habitat types; as such, it must be considered "good" for the plant comunity.

Upon Willing the sageirush, a nunber of unanswered questions come to mind:

1. After spraying, most ecosysteri nutrients are tied up in grass. What is tne long range effect on soil fertility and forage production of an increased rate of grass removal by livestock grazing?

2. The death of sagebrusi plants results in a loss of snow-stopping capacity of ranges in windy areas. Will this reduce the amount of moisture entering the soil on an annual basis, thereby reducing forage production?

3. The shading effect of sagetrush is renoved. iill the higher soil temperature cause more rapid evaporation and increased mortality of arass and forb seedlings?

4. Do plant communities with deep-moted plants make more efficient use of moisture and nutrients? Will the elimination of deep-rooted plants cause some moisture and nutrients to be lost to the system?

5. Soil under sagebrush plants appears to be more friable than betwecn plants. Uill the removal of sageurush, with continued heavy grazing, ultinately result in a decline in overall soil perineability?

one important question cuncornilly wildife comcs to hind. Shat are the long range effects of the los's of traditional range usu habits and patterns? In gane management it is practically axionatic that wild aninals are presently utilizins tine best iabitat resources available to tirem and tirat any change from the present would provail/ be to a less desirable situation. 
The assumptions underlying the oijective of greater grass and livestock production should also be questioned: cattle do not necessarily prefer grass during all seasons, and just because an area is treated is no assurance tilat cattle will convert the additional yrass into pounds, of red meat?

While this study did not answer all the questions, results did suggest that partial kill strif spray in small jlocks would ise a fair compromise for sagebrush rangelands scheduled for chenical conversion. 
bayless, S. 1367. Winter range use of pronghorn antelope in central Montana. (Fed. Aid in Vildl. Restoration Proj. Y-y8-il). 11.3. thesis, Montana State University, Bozenan. 65pp.

Becker, 3.i. 1971. Pronghorn-cattle range use and food habits relationships in an enclosed sagebrush control area (Job Prog. Rept., Fed. Aid in tildl. Rest., Proj. (1-105-R-7). M.S. thesis, $110 n$ tana State University, 3ozenan. $57 p p$.

Lecker, B.H. and Richard iallestad. 1974. Effects of chemical Sagebrush Control on mule deer in the Missouri River ureaks, Montana. In: Pyrah, $D$. and ilenry Jorçensen. Ecology of Sagebrush Control. Job ?rog. Rep., Proj. Wo. i $105-R-5$ : Mont. Dept. of Fish E Game. 129pp.

Sest, L.B. 1370. Effects of ecological changes induced by various sageirush control techniques on non-game birds. (Fcd. Nid in idild. Restoration, Proj. $(-105-R-5)$. M.S. thesis, Montalla Jtate In iversity, Bozeman. 74pp.

Cada, J.D. 1968. Populations of small mammals in central Montana with special reference to tentative sagelsrush control sites. (Fed. Aid in $1 \cdot i l d l$. Restoration, Proj. W-105-R). M.S. thesis, Montana State University, Bozeman. 52pp.

Campbell, R.B. 1970. Pronghorn, sheep and cattle range relationships in Carter County, Montana. M.S. thesis, Montana State University, Bozeman. 37pp.

Cole, G.F. 1356. The pronghorn antelope -- its rance use and food habits in central Montana with special reference to alfalfa. Montana Fish and Game Dept. and Montana Agri. Expt. Sta. Tech. Bull. 1o. 516. 63pp.

and 3 . T. Wilkins. 1358. The pronghorn antelope - Its range use and food habits in central Montana with special reference to wheat. iont. Fish and Game Dept. Tech. will. io. 2. jop.

iouey, F.H. 1346. Antelope foods in soutinastern lontana. j. Iildi. Mgtht. $10(4): 367$.

Eng, R.L. and P. Schladveiler. 1,72. jaye grouse winter novements and hatitat use in central Hontana. J. Iilil. lianage. $36(1): 141146$.

Feist, F.r. 1368. usecding bird pupulations in relation to proposed sagebrush control in central liontana. (Fed. Aid in Uildl. Resotration, Froj. 1-155-?). i.s. thesis, lontana "̈tate linivarsity, jozeman. 3ip.

Freerian, J.S. 1971. Pronghorn range use and relation to 1 ivestoch ir southeastern llontana. M.S. thesis, lont. State Univ., sozerian. 45pp.

Hewitt, G.j. and H.E. Rees. 1274. Auundance of yrassioppers in relation to range land renovation practices. Jour. Range ilgt. $27(2): 156-160$.

Jorgensen, ii.E. 1974. Vegetation typing of the Yellow water Triangle. In. Pyrain D. and ilenry Jorgensen. Ecolosy of Sageurushi iontrol. Jou Prog. Rep., iroj. iro. $.1-10-i-9$. Hont. Lept. of Fish E Came. $129 p p$. 
1375. Effects of sayeurush control treatinents on vegetation and on soil noisutre. Job. Prog. Rep., Proj. Vlo. 5331 (10), Job hos. V-1.2 and V-1.5. iont. Uept. of Fish and Game. 31 pp.

Knapp, S. 1975. Birney - Decker dildlife Study. Prog. Rep. Ho. 1. Mont. Dept. of Fish \& Game, E. E 1. Uiv. Lépp.

Aackie, R.J. 1970. Range ecology and relations of mule deer, elk, and cattle in the Missouri River üreaks, llontana. Uildl. Mnno. 20:79pp.

llartinka, C.J. 19i7. ilortality of northern llontana pronghorns in a severe winter. J. Mi ldl. Mgint. 3!(1):15\%-164.

Petcrson, J.G. 1970. The food habits and sumer distribution of juvenile sage srouse in central ilontana. J. Uildi. Manage. 34(1):147-155.

Pyrah, D.b. 1972. Effects of chemical and mechanical sagebrush control on sage 3rouse. Pages 16-25. In: Pyrah et al. 1972. Ecological effects of chemical and mechanical sagebrush control. Montana Fish and Game Dept., Job Prog. Rept. $w-10 j-P-6$.

- 1974. Fawn bedcing cover selection. In: Pyrain, D.B. and Henry Jorgensen. Ecology of Sagebrush Control. Job Prog. Rep., Proj. No: W-105-R-9. Mont. Dept. of Fish and Game. 129pp.

- 1975. The effects of sagebrush control on antelope. Final Report, Proj. No. 1-105-R-1-10. Hont. Dept. of Fish and rame. In Preparation.

juimby, D.C. 1366. A review of literature relating to the effects and possible effects of sagebrusir control on certain game species in Montana. Presented at the 46 th Annual Conference of Uestern Assoc. Of State Fish $E$ Game Commis. sioners. Butte, Montana. 13pp.

Reichelt, L. 1974. Effects of ecological changes induced by various sagebrush control techniques on small mammals. In: Pyrah, D.3. and Henry Jorgensen. Ecology of Sageurush Control. Joj Prog. Rep., Proj. No. 105-R-9. Mont. Dept. of Fish and Game. 129pp.

- 1974. Effects of ecological changes induced by various sagebrush control techniques on non-gane Lirds. In: Pyrah, D.5. and Hienry Jorgensen. Ecology of Sagebrush Control. Job Prog. Rep., Proj. Ho. 105-R-Q. Mont. Dept. of Fish and Game. 12spp.

Rowerts, 0. 1570. Post-treatment studies of antelope range use, food habits and behavior during the summer season. (Fed. Aid in Uildl. Restoration, Proj. $(1-105-k)$. $(1.5$. thesis, Montana State University, Eozeman. 56pp. .

Tschache, 0.r. 1970. Effects of ecoloyical changes induced by various sagebrush control techniques on small mamal population. (Fed. Aid in ilildl. Festoration, Proj. $(1-105-R-5)$. M.S. thesis, Clontana State University, Bozeman. 51 pp.

Jallestad, R. 1971. Summer movements and habitat use by sage grouse broods in central Montana. J. dildl. Manage. $35(1): 129-136$. 
- 1972. Effects of cherical and mechanical sagebrush control on sage grouse. Pages 1-15. In: Pyrah et al. 1972. Ecological effects of chemical and mechanical sagebrush control. ilontana Fish and rame Dept. Jou.Prog. Pept., $1-105-R-i$.

1973. Fall and winter habitat requirements of sage grouse in relation to sagebrush control. Pages 23-24. In: Pyrah et al. i973. Ecological effects of chemical and mechanical sagebrush control. Hontana Fish and Garie Dept., Joh Prog. Rept., Proj. $-105-P-7$. and 8.

and 0.3. Pyrah. 1974. ilovements and nesting requirements of sage grouse hens in central Montana. J. Hildl. llanage. 30(4):630-633.

and P. Schladweiler. 1974. Breeding season movements and habitat use of male sage grouse in central lontana. J. iildil. llanage. 33(4):634-637.

, J.G. Peterson and R.L. Eng. 1975. Foods of adult sage grouse in central Montana. J. Wildl. Manage. 39(3):628-630.

Ventland, H.J. 1968. Sumer range habits of the pronghorn antelope in central Montana with special reference to proposed sagcbrush control study plots. M.S. thesis, ilontana State University, Bozeman. 65pp.

\section{AIINUAL PRIJGRESS REPORTS :}

Pyrain, D. 1967. Ecological effects of cherical and mechanical sagebrush control. Job. Compl. Rept., Fed. Aid in Vildl. Restoration, Proj. 1:-105-R-1. 15pp.

and E.F. Schlatterer. 1968. Ecological offocts of chemical and mechanical sagebrush control. Job Compl. Rept., Fed. Aid in Vildl. Restoration, Proj. $1-105-p-2 . \quad 53 p p$.

Schlatterer, E.F. and D. Pyrah. 1969. Ecological effects of chemical and mechanical sagebrush control. Job. Compl. Rept., Fed. Nid in $: / i l d l$. Restoration, Proj. $W-105-R-3 . \quad 39 p p$.

and 1970. Ecological effects of chemical and mechanical sagebrush control. Job Progress Rept., Fed. Aid in Wildl. Restoration, Proj. W-105-R-4. $121 \mathrm{pp}$.

Pyrah, D., H.E. Jorgensen, and R.0. Hallestad. 1971. Ecological effects of chemical and mechanical sagebrush control. Job Progress Rept., Fəd. Aid in $V / i l d l$. Restoration, Proj. it $-105-P_{1}-5$. $110 p p$.

and 1972. Ecological effects of chemical and mechanical anical sagebrush control. Job Prog. Rept., Fed. Aid in ilildl. Rest., Proj. id-105-R-6. $76 \mathrm{pp}$.

and 1973. Ecological effects of chemical and mechanical sagebrush control. Jó Prog. Rept., Fed. Aid in Uildl. Rest., Proj. $\forall-105-R-7$ and 3. i $32 p p$.

and 1974. Ecological effects of chemical and mechanical sagebrush control. Job Prog. Rept., Fed. Aid in !/ildl. Rest., Proj.1-105-R-9. (in preparation) 
Jorcensen, H.E. 1975. Effects of sageurush treatments on vegetation and on soil moisture. Job. Final Rept., Proj. 5331 (1), Mont. Dept. of Fish and rame. $31 \mathrm{pp}$.

With segments prepared by other authors. 
Q: Sagebrush has always been common to the mountain grasslarids. Why do you consider it an invader?

A: What is an invader?

Q: The term, as I recall, is it moves in with so called misuse or overuse.

A: Right, we've created a situation artificially that made sagebrush a better competitor and better able to maintain itself under those conditions. In lots of situations there is enough soil loss that you permanently drop down that site potential. Removing the sagebrush is not automatically going to give you a better stand permanently of grass that you used to have because you brought it down to a more primary stage of succession. We have a place on the Beaverhead Forest where with very low intensities of grazing, the densities of sagebrush ten years after spraying are much greater than before they sprayed and now they are going in to spray again. It was not because of overuse, it was because maybe the initial overuse had reduced the site potential to that. With induced soil loss you completely change the ball game. 


\section{INTEGRATED PEST MANAGEMENT - ALFALFA}

Total reliance on chemicals to control pests of our agricultural commodities has failed on many important crops. Failures can be attributed to development of pest resistance to chemicals, increasing cost of pesticides, the elimination of beneficial insects, and to environmental pollution resulting from pesticide use. Even though pesticide control has failed in many instances, most crops could not be grown on a large scale without at least emergency access to these chemicals. Complete natural control has been achieved for very few agricultural pests.

Natural control agents and beneficial cultural practices usually cost littie or nothing. Yet, too of ten these essentially free pest control components are negated by prophylatic pesticide treatments. Pesticide treatments are to often dictated by the calendar rather than by need determined by the presence of an intolerable pest population. As more and more crops fall victim to the pesticide dilemma, the need for a new approach based on sound ecological principles becomes more apparent.

An ecological approach to pest control would take advantage of naturally occurring control agents, cultural practices, and the judicious and timely use of selective pesticides. This approach has been called ecological, complementary, or integrated pest management. Ideall:, an integrated pest management system would have available such scientific input as the ecologies of the crop, pest, the pest's natural enemles, and interrelationships existing between all three. In addition, the economic thresholds and economic injury levels need to be known for each potential pest. The economic threshold is defined as the density of an increasing population where control measures should be determined. The economic injury level is the lowest pest population density that will cause economic damage and economic damage is the amount of

Presented by Dallas Miller, State Program Manager, State Assistance Section, Pesticide Branch, Air and Hazardous Materials Division, Region VIII, Denver, Colorado 
crop injury that will justify artificial control measures. 5 Al though knowledge of the aforementioned components would allow the greatest chances of success of a pest management program, a producer with adequate knowledge of his crop can inst itute changes in his pest control practices using an intuitive approach.

Alfalfa production offers an example of a graduated approach to integrated pest management. The most economically important pest of alfalfa grown for forage is the alfalfa weevil, Hypera postica Gyllenhal. The weevil was first discovered in the U.S. in 1904 near Salt Lake City, Utah. A search for parasites of the weevil throughout Europe and Asia resulted in the importation of several weevil parasite species. Of these, Bathyplectes curculionis became established throughout the weevil's range and provided a degree of weevil suppression. 4 However, with the advent of the pesticide boom in the late 1940's and 50's biological control of the weevil gave way to chemical applications. One insecticide, heptachlor, offered excellent control of the weevil for several years. This answer to the weevil probiem ended in the early 1960 's with the discovery of heptachlor residues in milk and the development of weevil resistance to heptachlor. Weevil resistance was reported in 1964 and was found in weevil populations in several sections of the county. 1

Weevil control with pesticides gradually gave way to more reliance on weevil parasites, a more judicial use of pesticides and to the use of pesticides offering a shorter residual life. Today, complete natural control of she weevil has been achieved in some areas of the country, particularly in the mid-atlantic states. Substantial natural control exists in other areas such as in parts of California. 3

In the western states, the weevil is still the most damaging pest of forage alfalfa. Lygus bugs are probably more damaging than weevils on seed alfalfa. Since the alfalfa management program depends on the crop usage, we will consider both seed and alfalfa forage production.

The most damaging pests of seed alfalfa ranked according to economic importance are Lygus bugs, pea aphids, alfalfa aphids, and the spotted alfalfa aphid. Two other 
pests of occasional imfortance are the alfalfa seed chalcid and the two-spotted mite. Alfalfa weevil management will be discussed under alfalfa forage production, but should be considered in seed production management since this pest can destroy an alfalfa stand before seed pods form.

A primary consideration in any integrated pest management program is to preserve the naturally occurring control agents, the predators and parasites. This requires (1) determination that a chemical treatment is necessary before applying a pesticide and (2) a careful choice of pesticides and application timing. The key to determining the need for pesticide application is sampling. A standard 15 inch diameter sweep net is most practical for sampling purposes. Twenty-five sweeps for field satisfies the minimal requirements, but more sweeps should be taken in large fields and during critical pest periods. Five sweeps should be taken on each field side. These sweeps should be taken thirty feet from the field edge. The remaining five sweeps should be taken in the center of the field.

Washington State University researchers have outlined five integrated programs that provide excellent seed alfalfa management. 6 These include programs using (1) Trichlorfon, or (2) aldicarb granules, (3) or Carbofuran, (4) or Dimethoate (5) or Supracide. Demeton was added to suppress aphid populations when aphid density reached 100 per sweep. Trichlorfon applied at a rate of one pound active ingredient per acre is recomended for the rest of the season when lygus nymphs exceed ten per sweep or when fourth instar lygus nymphs are found. Twenty nymphs per sweep can be tolerated in the late season.

There are several basic differences in pest management on alfalfa grown for seed and forage alfalfa. Forage alfalfa must be considered a low income crop. The value of the crop affects the economic damage level in that high damage levels must be reached before chemical treatment can be economically justified. Consequent ly, there is a need for non-chemical control measures for forage alfalfa. 
By far, the most damaging pest of forage alfalfa is the alfalfa weevil. Another pest that has reached economic importance in some areas of the country are agromyzid leaf miners. 8 Several other pests are found in forage alfalfa, but rarely justify control consideration. These include several plant bug species, leafhoppers, spittlebugs, grasshoppers, alfalfa caterpillars, mites, and aphids. The two-spotted alfalfa aphid has presented control problems in the past in parts of California, but is currently effectively controlled by parasites. 4

In the eastern United States, natural control of the alfalfa weevil is spotty. In most of Hampshire County, Massachusetts, weevil population do not reach economic injury densities. However, in the adjacent Beckshire County, weevil damage on the first alfalfa cutting is generally severe and requires control considerations. Several mass parasite releases were made in Hampshire County in the early to mid 1960's (2) and weevil control is attributed to the activities of the parasites, particularly, Bathyplectes curculionis Thoms. Weevil parasitism rates in Beckshire County are low compared to Hampshire County, 9 and the more severe weevil damage in Beckshire County can be attributed to the lower parasite density.

In 1970, I undertook a study of certain predatory insects in Beckshire County to determine their effect on weevil populations. The study procedure included both laboratory feeding studies and an immunological study of the stomach contents of field collected predators. Laboratory feeding studies indicated that several predators would readily accept weevil larvae as prey. These included several ground beetle species, two predaceous stink bug species, a damsel buç and two lady beetle species. An immunological study of the stomach contents of field collected predators confirmed predation by Nabis rufusculus, a damsel bug, and the two lady beetle species, Colemegilla maculata and Coccinella trifasciata Linne. Other species were immunologically examined, but not in sufficient numbers to establish a field predation pattern.

The field predation study did establish that the alfalfa weevil is preyed upon 
by naturally occurring predatory insects. Bathyplectes curculionis and several other parasitic species have demonstrated their ability to suppress weevil populations in scattered areas of the United States. These beneficial species must be protected to derive the maximum benefit from naturally occurring weevil mortality factors and thus minimize alfalfa production costs. To protect beneficial species, pesticide applications must be utilized only when sampling determines weevil populations that will cause economic injury.

The weevil is generally an economically important pest only on the first alfalfa cutting. Also, the largest percent of alfalfa defoliation occurs in the last stage of weevil larvae growth. The majority of the weevils can be destroyed by harvesting the first alfalfa crop early. Early harvest has a minor effect on natural enemies and in most cases eliminates the need for spraying.

Koehler and $\mathrm{P}$ imental ${ }^{7} \mathrm{l}$ isted seven environmental and plant growth factors that should be measured to increase the accuracy and reliability of economic injury levels. These factors are (1) alfalfa weevil larvae density, (2 and 3) parasites and predators of the weevil, (4) rainfall and moisture level, (5) plant nutrients, (6) alfalfa variety, and (7) stage and previous management of the alfalfa stand. Certainly, plant vigor and current growing conditions do affect the ability of the stand to recover from weevil damage and these changes in these factors will affect the economic injury level.

Chemical control measures must be based on need for the treatment established by a weevil survey. Two survey methods applicable to farm use are (1) percent of weevil damaged growing p'ant tips and (2) the sweep-net method. When more than seventy-five percent of the plant tips exhibit feeding damage or when more than twenty weevils per sweep using a fifteen inch sweep-net are collected, control measures should be considered. The seventy-five percent tip damage or twenty weevils per sweep may be a lower economic injury level than others have suggested and can vary according to growing conditions. 
The development and utilization of integrated pest management systems on all crops would drastically cut agricultural production costs. Cutting production costs on low value crops such as forage alfalfa is particularly important. Pesticide applications to control the alfalfa weevil on forage alfalfa can be minimized by: (1) using a sampling procedure to determine the need for pesticide application, (2) harvesting the first alfalfa crop early when weevil larvae densities are high, and (3) applying a pesticide that does the least harm to beneficial insects when pesticide application is warranted. 
1) Adler, V.E. and C.C. Blickenstaff. 1964. Resistance of the alfalfa weevil to heptachlor. J. Econ. Entomol. 57 (2):299-300.

2) Bronson, M.H., and L.W. Coles. 1968. The introduction, release, and recovery of parasites of the alfalfa weevil in eastern United States. U.S.D.A., A.R.S. Production Res. Rep. 101.

3) Council on Environmental Quality. 1972. Integrated Pest Management. U. S. G.P.O. P. 41 .

4) DeBach, P. (ed.) 1973. Biological Control of Insect Pests and Weeds. Chapman and Hall LTD, London, P. 844.

5) Hoyt, S.C., and E.C. Burts. 1974. Integrated Control of fruit pests. Ann. Rev. Entomol. 19:231-52.

6) Johansen, C.A., E.C. Klostermeyer, A.H. Retan, and C.R. Baird. 1974. Integrated pest management on alfalfa grown for seed. Nat'l Pest Control Operator News $34(9): 22-4$.

7) Koehler, P.G., and D. Pimentel. 1973. Economic injury levels of the alfalfa weevil (Coleoptera: Curculionidae). Can. Entomol. 105:61-74.

8) Miller, D.E., and G.L. Jensen. 1970. Agromyzid alfalfa leaf miners and their parasites in Massachusetts. J. Econ. Entomol. 63(4):1337-8.

9) Miller, D.E., and R.R. Shaw. 1969. Forage Crop insects in Massachusetts in 1969. Coop. Econ. Insect Rep. 19(47):849-50. 

The problems of pest control, which some thought were solved, when the pesticidal properties of DDT were, sroven over 30 years ago has reached a more challenging point for the future and taken on a more complex and divergent direction than could have been anticipated even 15 years ago.

To at tempt to predict what the future may hold in the areas of pest control or pest management becomes a guessing game of an extreme type. However, some of the directions, on which attention is now being focused, could give us some idea of what we might expect, a: least in the near future.

There is no question in the minds of anyone, that effective control of pests throughout the world will be, not only increasingly necessary, but also increasingiy difficult. The difficulty, lies not in developing methods and techniques for controlling pests, but in developing these methods and techniques that will control the specific organism that we have designated a pest, without destroying other organisms, and without contaminating the environment and without creating a hazard to man. And so the opportunity becomes increasingly difficult, increasingly complex and certainly challenging to those who dedicate themselves to the solution of that problem.

We can no longer utilize the criteria for developing pest control methods that were successful in the past. Previously, we sought an inexpensive product, that controlled a broad range of pests for a long period of time following application. Those criteria are no longer valid. A long persisting product is no longer an acceptable criteria for developing pest control methods, simply because the impact of that particular characteristic may cause, under some circumstances, undesirable damage, in desirable organisms at locations far removed from the site of its use.

Presented by Lemac Hopkins, Technical Advisor, Environmental Quality Chevron Chemical Company, San Francisco, California 
We can no longer accept, as a valid criterion, the ability of a product to control a broad range of pest, simply because such a characteristic may cause the product to be destructive to closely related species that we wish to encourage and utilize in pest control programs.

And while the area of economics is an important characteristic the criterion of an inexpensive product is no longer valid, simply because the cost of finding, developing and registering the product for use has inflated at a tremendous rate. A large part of this cost has been created by the requirements of various government regulatory agencies, but there are also many other factors influencing product costs. Some of the basic reasons why we cannot expect, so-called, inexpensive products for future pest control programs, is revealed in a recent study of the pesticide industry by the consulting company, Ernst and Ernst.

This study shows that in 1967 , only eight years ago, it cost only $\$ 3.4$ million to discover and commercialize a pesticide product. In 1970 it cost $\$ 5.5$ million, in 1973 it cost $\$ 6.1$ million and in 1975 its estimated at about $\$ 8$ million. Consequently, a chemical that cost $\$ 3.00 /$ pound in 1967 would now cost $\$ 8.00 /$ pound. In this same report it showed that in 1967, a company must evaluate 5,500 different chemicals before one was found that would meet the criteria of an acceptable pest control product. In 1970, 7,400 chemicals were evaluated befcre one was found acceptable. In 1973, the number was 10,200 and today it's prcbably over 12,000. The chemical industry must now synthesize 12,000 chemicals, on the average, before an acceptable pest control material, that will meet the present criteria, is found and put on the market.

Government regulations and requirements have had a direct influence on the increases just mentioned. However, perhaps the greatest impact on developing products has been in the time required between the discovery of a product and the time it is allowed to be marketed, i.e., until it has received a label clearance. In 1967 , this period of time was 60 months (five years) in 1970 it was 77 months, and in 
1973 it was 80 months. In 1975 it is probably 85 to 90 months or about seven to eight years and this is expected to increase even more.

So now you can see why the inexpensive compound criterion is no longer valid. For each pest control product that comes on the market in 1975, it will cost eight million to develop, after screening 12,000 compounds and will require over seven years to get it into the hands of the users. These figures also give you a clue as to why you will be seeing fewer and fewer new products on the market in the future.

Now let's be a little more specific in what is going on in the area of pest control and give you some ideas of the trends in pest control that are being evalwated in laboratories and experiment stations throughout the country.

At the present time there are four major areas of pest control developments that might be of interest. There are the chemical Control Methods which are a progression and refinement of the chemical controls that have been used so widely and so successfully in the past. The information I previously gave, applies primarily to this area of pest control.

Then, a relatively new and exciting area of pest control that utilizes chemicals of a greatly different type is the biochemical, physiological or hormonal control. A lot of emphasis is being placed in this area and it's a costly, slow moving program.

And the third area that will become increasingly important, as we learn more about the Techniques, is natural or biological control and included in this area is the use of diseases and insects for the control of specific pests.

The fourth area is combination of all other methods and is generally referred to as Integrated control or pest management. This method simply utilizes the most desirable and effective parts of all other methods, where they are brought together in one program to reduce damaging pest population. Obviously, the proper manipulation of several methods will require a great deal of knowledge and information before an acceptable and reliable program can be developed.

Pest management and Integrated Control programs are receiving a lot of publicity 
since it appears to be the most logical and sensible method. Such programs are being proposed and implemented even today, simply because if a grower gets into trouble with his integrated program, he can resort to some of the chemicals that are on the market and that he has used in the past to get him out of trouble. The future may not see this broad array of chemicals available for almost any pest that we have now. This means that once this integrated program is developed, they must be right and followed very closely - because the chemical controls may not be as readily available as in the past.

I'm confident that given enought time acceptable pest management and integrated control programs can be developed. Chemicals will be used as a basic part of such a program rather than for the entire program as in the past. But this type program is far from being perfected for today's use in modern agriculture.

Let's discuss a little of what's going on in the chemical laboratories as we seek new and more acceptable chemicals to be used in pest control programs.

One of the most important considerations for a potential pesticide chemical is its possible potential impact on the environment. A large amount of time and money is now being spent in carefully evaluating the environmental impact of the chemical. This phase of chemical development in the past, was relegated to a lesser role than it is today.

In the past, the sole criterion for a pesticide was will it kill the pest when used in small quantities? Now that is only second or third in importance as we develup new, sophisticated and environmentally acceptable cheriicals for pest control purposes .

One of the drawbacks in developing pest control chemicals on this basis is that the degree of pest control may be reduced. In other words rather than getting a $98 \%$ reduction of pest populations such as we've hoped for in the past, we may now have to be content with an $85 \%$ reduction in order to obtain a specified degree of environmental protection. 
A few years ago, our criteria for a pesticide was that it be effective for a large number of pests, that it be relatively inexpensive, that it could be used on several crops, that it he long lasting.

Here are the characteristics we evaluate today in developing a new pesticidal chemical. Environmental safety, effectiveness against the pest, safety to man, market potential, cost and liability risk.

Trying to get all these factors into one product is very difficult if not impossible. We sometimes must settle for less than we want. In order to meet some of these characteristics, you can expect to see an increase in the number of systemic products. Such products when applied, are rapidly absorbed into the treated crop, where it retains its pest killing powers, while any residue on the soil or crop surface is rapidly broken down and dissipates thereby creating very little, if any, environmental harm. To go a step further, many of these products will be designed for soil injection and if water soluble, will be rapidly absorbed into the crop giving the required protection while exposing the environment to relatively small amounts of chemical. Since such products will be designed to break down rapidly in the soil, the chances for environmental mobility is practically eliminated. Can you visualize how important such a chemical would be? The possibility for a systemic fungicide for small grains that meet these criteria is unlimited - and hopefully, the future will see them. The same product may be applied to the seed so that it is absorbed upon germination. The possibilities are exciting. This typc of control is in the future. There will be fewer environmentally persistent chemicals that could create undesirable or controversial side reactions. The length of time a pesticide remains effective will be control led by "build in", i.e., formulated in, time clocks. We may be able to predetermine the length of time a chemical persists simply by varying the formulation. If we want a product to. last three days or 10 days this may be done through formulation techniques. 
Such factors as micro-encapsulation, variable granulation, water solubility will be perfected and used to reach these objectives.

Pesticide dust formulation is on the way out. The use of dusts is a very crude way to apply chemicals, especially in limited areas. We will no longer need dusts to get coverage since we will be able to do that through the use of our water soluble, rapidly absorbed, highly effective systemic chemicals.

The future holds unlimited possibilities in the area of chemical pest control. And now that the objectives for new chemicals have been generally established and the criteria for evaluating such chemicals more or less accepted, about all we need now is time, money, patience, and freedom from government interference.

The field of biochemical insect control has developed only during the past few years. Yet, it has made rapid strides and already a few prodicts of this type are on the market.

Probably the first of this type of control chemical was the sex attractants where traps were baited with a chemical for luring the male pest insects into the traps and was first used in insect detection work. These biochemicals are a useful tool for surveying, scouting, and detecting, but their use as a pest ccntrol tool appears to be limited - at least for the present.

Those products that appear to be making the most progress and are being developed as reliable and capable pest control chemicals, are the Insect Growth Regulators. Specifically, the juvenile hormones have generated the most interest, and it is in this area that the first commercial products are developed.

Although we refer to these chemicals as "biochemicals" they are being synthesized so they must be considered man-made or perhaps copies of naturally occurring chemicals.

These juvenile hormones are chemicals which control or otherwise affect the growth and development of various insect stages. Such chemicals may be effective at the egg stage through the pupal stage, depending on the insect, as well as other 
factors. These hormones essentially prevent or prematurally cause morphological change in the insect. If applied to a larva during its last stage of growth, the larva will not produce a normal adult, since most die in the pupal stage. On the other hand, these insect growth regulators, if applied early in the larval stage, may slow down the growth so that they feed for a longer period of time. In some cases, improper timing of an application of insect growth regulator may result in giant larva, simply because they feed and grow over a longer period of time. The present use of juvenile hormones appears to be limited to the control of those insects that are pests during their adult stage, such as mosquitoes, flies, and gnats. Some degree of success has also been obtained in feeding certain of the juvenile hormones to cattle to control horn $f l$ ies and to poultry to control house flies, both of which breed in the manure. The juvenile hormone in the manure prevents the development of adult flies and populations are rapidly reduced.

It would seem that as we progress in the area of hormone control that additional types of these biochemicals will be discovered, stabilized, and used in specific pest control programs. We've hardly scratched the surface of pest control using this type of chemical. Laboratories are synthesizing new chemicals everyday, some of which exhibit insect growth regulator tendencies.

Another group of biochemicals that is receiving a great deal of attention is the chemosterilants. These hormone type chemicals, when fed to normal insects, result in the sterility of one or the other sex. In some cases, it depends on the concentration of the sterilant as to which sex is rendered sterile. The objective in using these chemicals is to cause the laying of infertile eggs, thereby, resulting in the destruction of the pest before it reaches the damaging stage. The possibility also exists that by feeding low levels of these chemosterilants to developing insects, it may cause them to be sterile upon reaching sexual maturity. This type of action would result in a rapid population decline and the desired crop protection. 
There is also a group of biochemicals called pheromones which generally are used as confusers. These materials when used in an area may attract males away from the females so that mating does not occur. Such chemicals are showing some potential in control of certain pests in forest and orchard areas.

It is obvious that the techniques for the successful and reliable use of the biochemical or hormone chemicals is a long way from being perfected. But the future hold solution to many of the problems, researchers today are faced with in this method of pest control. Scientists today are developing techniques for synthesizing these hormones, for discovering the most effective types and finding formulations that are stable enough to be used on a commercial scale. Many of these types of chemicals are highly unstable to light, moisture and temperature which results in great difficulty in developing acceptable formulations. In addition, the biochemicals must be evaluated for their impact on the environment and man. It would be disasterous if some of these hormones were widely used, and then found out they affect man or certain species of animal in the same manner as they do insects. Such questions must be, and are being, answered, before these products can be utilized in an overall pest control program.

The future will see an increasing number of the biochemicals released for specific pest control problems. I do not want to infer or mislead you into believing that the development of these chemicals will become the ultimate answer for agricultural pest control. Problems associated with these are many and will be difficult to solve. We can be optomistic, however, about the development of these methods for the effective control of specific organisms in limited situations in the future.

The area of biological or natural control methods, is one of the oldest methods of pest control known. However, only in recent years have we attempted to manipulate these factors into an improved and effective pest control program.

The use of insect diseases as a control method resulted in the improvement and 
rather wide use of the organism "Bacillus Thuringiensis" for the control of several species of leaf eating insect larvae on several different crops with varying degrees of success. High potency formulations have been developed that have increased the reliability and effectiveness of the disease. Research is continuing in this area of pest control and such organisms as polyhedrosis, nosema, entomopthra, and insect viruses are being studied and evaluated for future use. These organisms, all of which occur naturally, are sensitive to many factors, including moisture, temperature, light, host densiry and others. Under ideal conditions many of these organisms will develop naturally into effective deterrents against specific pests. Out objective is to learn the secrets of these diseases and to use them to the greatest advantage.

In addition to the use of disease organisms for pest control, the use of predator insects and parasites are also included in biological control programs. The releases of large numbers of artificially produced insects of this type have been used to reduce and control population of pests. However, this type of use is not the ultimate objective in the development and utilization of biological organisms for pest control.

The basic objective of the application of biological and natural control is to encourage and perpetuate the naturally existing populations of these beneficial insects, so they will maintain the insect pests at a level where economic damage will not result.

The successful use of biological or natural methods of pest control will require knowledge of both the pest and its predator. In order to be reliable, a grower must be fully aware of this relationship in order to effectively utilize it. A large amount of research in this area will be needed before sufficient information can be obtained for developing satisfactory pest management.

The use of predators and parasites for pest control will always be limited at 
best, and will probably never result in acceptable crop protection programs, except in very limited or isolated situations. This method, can, however, with additional knowledge, be utilized along with other methods into sound pest management or integrated pest control programs.

Up until now, most of the comments have been directed toward insect control. However, the control of crop diseases and weeds are equally important and the same general factors and comments apply to them - except control problems may be more difficult.

Crop disease control lends itself to two methods of control, i.e., development of disease resistent varieties and specific chemicals, used as preventives rather than eradicants. I do not anticipate any change in this in the future. However, chemicals for disease control will follow the same pattern as for insect control. They will be systemic and will protect from the inside, al though surface contact control will continue to be imperative.

In weed control most of the effort of research is in the area of soil applied chemicals that are very narrow in their range of effectiveness and which breakdown rather rapidly once they are applied. Proper timing of the application of these new herbicides will be of critical importance. Their impact on the environment and other organisms will be the limiting factor in their development and use. There will also be systemic herbicides developed that are absorbed and translocated to the root system which will result in the destruction of the plant. Such chemicals may be narrowly effective, or if broadly effective will requile that the ir use be very carefully controlled and confined. Such post-emergence chemicals, when used in a program with the soil applied chemicals should result in excel lent weed control in most crops for the future.

We can expect to see increased effort in the area of weed control which hopefully will result in additional chemicals for agriculture, but which will probably be for 
limited use, perhaps fo: only one or two crops, and perhaps for the control of only one or two weed species in that crop. Such chemicals will be expensive, but this must be expected of "custom developed" chemicals designed for the specific solution of special problems.

The final area of pest control that must be considered is Integrated Pest Control or Pest Management. This is essentially just a new name for programs that we've utilized in the past. However, the new emphasis is now on the increased utilization of the so-called environmentally acceptable methods of pest control rather than relying exclusively on chemicals.

These pest control methods are aimed at incorporating all known methods of pest control whether insect, diseases, or weeds, into one program beginning with the use of resistant varieties and ending with the destruction of the crop residue. The success of such a program depends on our knowledge of crops, pests, conditions and methods. Much of the information needed to reliably and satisfactorily incorporate all the know methods of pest control into one "crop-long" program is not yet available from our research and experiment stations. Yet there are many things that can be done, that will result in better crop protection as well as protection to the environment. As the required information is obtained and disseminated to the grower, the use of integrated pest control programs will become a reality, but the use of chemicals cannot be el impinated for they offer the only reliable and dependable course for immediate pest suppression if a serious outbreak of a pest occurs. Chemicals will continue to be the "backbone" of pest management programs, there is no reason to suspect they will not continue to be needed in agriculture, although their numbers will continue to shrink,

I hope the time never comes when we find a great need for a pest control chemical, then find there is none available.

It continues to appear that it will be much easier and far quicker for the government to ban and prohibit pesticides than it is for industry to discover and develop 
acceptable substitutes. At the rate we are now going, we may find ourselves without adequate pesticides required to protect our agricultural production in the near future. With this uncertainty it is increasingly important ihat we be aware of other possible pest control methods even though such methods may be ineffective at best. Perhaps combinations can be utilized in an attempt to continue food production at an acceptable level.

I am not optomistic about the reliability of the alternate methods of pest control. The correct use of pesticidal chemicals is still the most reliable, most effective, and most economical method of pest control available to growers - not only for the present, but also for the near future. We cannot survive if we must rely on the alternate methods at their present state of development, and so it's important that we do not rush short-sightedly into banning a large number of useful chemicals without thoroughly and adequately evaluating the severe impact of such action against the minor risks of the carefully controlled use of these chemicals. Yet the Federal Government seems to blindly continue on this suicide course of destruction.

We can expect changes in our pest control programs, but the changes will be expensive, the controls less effective and the results less than satisfying. However, specific chemicals that are Jeveloped will be more sophisticated, will continue to be more effective, but on a narrower range of pests, but will be more acceptable to the environment.

Our aim for pest control in the future is to maintain a satisfactory balance between the need to protect man and his food, and fiber crops, and the environment. Industry is moving in this direction. 
Q: Dr. Hopkins, I believe that those of us who are opponents of pesticide management would agree with you that we are putting you in a rather precarious position because we are asking you to spend more and more money on pesticides which will control fewer and fewer pests. However, you did say that probably in the future we will have pesticides that will be less effective and in an ideal pest management program, perhaps we are no longer interested in total elimination of the pest species, but merely maintaining them at a subeconomical level. Also since we are interested in narrow spectrum pesticides, I am going to assume that perhaps in your arsenal of chemicals, which you have al ready probably discarded because they are too narrow or because they were not effective, perhaps we can now go back and look at some of the already screened pesticides and maybe use them.

A: I don't think there is any question that there are chemicais setting on the shelves in many of these laboratories across the country today that would probably meet some of the requirements of pest control as we see it for the future. The question is, can we afford to go back and re-evaluate all of those chemicals aga in in order to find a chemical, perhaps one chemical that is very narrow in its use potential. The cost is getting prohibitive in that respect. I think one of the problems with the biochemical situation, the use of the hormones, that 1 mentioned, the first product that came on the market. The last time 1 talked to the people that made $i t$, they said they had over $\$ 16,000,000$ al ready invested in that chemical and they didn't see how they could possibly recover their cost by using that chemical just on mosquitoes, horn flies or house flies. I think that probably illustrates the problem when you look at the very narrow range of pest control that you might like to incorporate into an integrated pest management program. Admittedly, it would be the type to be used if they were going to be available. I just don't think they are going to be available except perhaps on the major crops. Because you have to look at volume to get your money back. You may be right and I am sure there are chemicals on the shelves today that are good pesticides, but I'm not so sure that anyone is going to go back and take the time, money and the man power to try to find those to re-screen them and find those which might fit into the integrated pest management programs.

Q: Are herbicides, is their cost any where near as expensive as for insecticides?

A: Yes, it is going to be about the same. Of course, you are looking at all the many requirements that the EPA is asking for on pesticides. It's not just the parent chemical, it's as you know, the metabolites. We have got to trace every metabolite to $i$ ts end point, you have to determine toxicity, the effect on reproduction and the environment in which you may want to use that chemical. We have a product that has been in the state of development, it's a herbicide for rice, fairly narrow market in this country. It's a good market and it's an exceptionally outstanding pesticide for weed control in rice. But EPA is running us nuts asking for additional information on metabolites. They want to know what goes into the stem, what goes into the bran once you thrash it, what goes into the grain, how much is left in the water, what goes into the soil and all the organisms in both water and soil. By the time we get all that information together, we have what the economics of the situation is. I would say yes with herbicides it is going to be just as bad as it is with insecticides.

Q: One other question I wanted to ask is what is your RD program? Are you using a criteria such as economic gain, that is, ton of protein gain per acre in alfalfa as a means of evaluating the effectiveness of your material? 
A: We would look at that if someone would pay for the difference and if it was a big enouyh factor, yes. But right now, I think, we, when we look at a potential market for any of these chemicals, we have to look at the biggest market we can find with the biggest potential under the existing uses of those particluar chemicals.

?: Let's take corn, do you look at the anount of protein yicld or what they furnish or tons of corn or ...?

A: We look at tons of corn, well we don't really look at that. What we look at is the acres of corn that this chemical may be used on in competition with whatever other chemical may be out there. If that's an $x$ number of dollars time a tremendous large acreage, that we have to go back with the figure and that is what we look at. No, we do not look at the protein content or the increased food value or anything else. If we can't afford to look at that until someone says that is worth $\$ 1$ an acre or $\$ 2$ an acre and then if our product $f$ its that, yes then I think that would be a consideration, but at the present time, I would say no and I amy be wrong, I don't know.

Q: I agree with your concept, we are heading more and more towards systeric type compounds, but in terms of our concerns for residues in foods, how do you coordinate that?

A: What's going to happen once these chemicals get into the plant food crop is that they are going to have to be metabolized or broken down within that plant to products that are nonhazardous. You still have to trace their metabolites out to its end point and especially those that are in plants. It's going to be long and it's going to be more expensive, there's no question about that. But somewhere and under all the systemics that I know of, once they get into the plant will be metabolized to the nontoxic level. In many of the cases, you are talking about phosphate bearing compounds and $n i t r o g e n$ bearing compounds which in some cases, you can get a response from the if and the $P$ in the plants. Eut it's going to mean that you may put a chemical on three weeks before harvest rather than three days as an example, in order to give it ample time to break down. Then if we can develop chemicals that we can control the breakdown on, perhaps then that would answer some of the questions that you were talking about. I think our objective is to end up with, if I may say, zero tolerance of these chemicals in crops. I think we are going to have to look at that as the end point. Twenty years ago we said that on tenth part per million, that was zero and now we talk about parts per trillion and that's not even considered zero any more. think that we have to look at the end results if we are going to plan not to have any residue, any toxic residue, on that plant.

Q: As Dr. Jensen had suggested to go back and look over these chemicals for a ten year period, you would have to look at over 34,000 chemicals to cone up with four successful ones. How many of those that weren't very good do you keep around?

A: For a period of time, we keep a shelf sample of most of those, but we keep information on all these as to how they were synthesized, many of them perhaps for reasons so that if anything does go wrong at least we will have a patent protection on them. don't think it would be a difficult problem to go back and re-synthesize, but I think it's the cost and the manpower that is going to be a limiting factor. Many chemicals that are on the shelf and that may fit a limited area may fit into an integrated pest managenent program very well, but will never be reserected simply because we've got tc look at the future. If we discover a chemical today, as an example, we are looking at 1983 or 4 or 5 before that thing can be on the market. Who's to say what perameter for pesticides will be in five or six years. They may change as much in five years 
the future as they were five years in the past. Those chemicals which have been discovered and that are setting on a shelf, I think are going to remain. I think we are looking at far more sophisticated chemicals than those are.

Q: Are these formulas computerized? Any of them?

A: I am sure that in our case, they are all in microfilm or on tape somewhere in our computer system, yes. Any of those that show any biological activity at all certainly are.

2: In other words you could get them pretty rapidly if you needed them.

A: I think if we needed them we could recover them fairly rapidly, those that show biological activity.

2: You may be aware of this, but 1 would like to bring it up for a point of interest under biological control. For example, this year the American Phytopathological Society met in Houston, Texas and we have just this year established a committee of our plant pathologist society on the control of weeds using plant pathogens, this is an area that is just beginning to be really analyzed as far as arnount data. There are no cases of real successful use of a rust for example, for weed control because of the problems involved in it. So far as plant pathologists looking at biological control this is just in its infancy in our area.

A: I think there are many other areas that will be developed in the future along these same lines. We have been in this situation for 30,40 , or 50 years and just now we begin to realize that perhaps we can use a plant disease to control these obnoxious or undesirable plants.

Q: Arkansas demanded the use of a fungus for northern joint vetch control in rice last year. 

A program was undertaken to develop zinc phosphide as a replacement for the more hazardous toxicants currently available to control black-tailed prairie dogs (Cynomys ludovicianus). Laboratory grain acceptance tests, $L D_{50}$ determinations, and bait development bioassays led to selection of $2 \%$ zinc phosphide-treated oats. In 30-day secondary hazard bioassays, minks (Mustela vison) showed no effects from eating entire carcasses of prairie dogs killed with this bait. Four field tests at 15 blacktailed prairie dog colonies in Montana, Colorado, and Nebraska showed consistent ly high reductions in prairie dog activity (76 to $96 \%$ ) when colonies were prebaited and the bait was applied in surface bait spots at the low rate of $4 \mathrm{~g}$ per burrow. Extensive surveys during these trials showed no primary or secondary hazards to any nontarget species. Experiments to measure zinc phosphide residues in range vegetation showed that baiting, even at a much higher rate than $4 \mathrm{~g}$ per burrow, cause virtually no environmental contamination. This series of studies produced a recommended method for control of black-tailed prairie dogs: Prebaiting followed by one surface application, at $4 \mathrm{~g}$ per burrow, of a bait formulated from steam-rolled oats, $2 \%$ zinc phosphide, and $1 \%$ corn oil. All evidence from the laboratory and field tests indicated that this treatment is effective and safe, and that the risk of its resulting in either primary or secondary intoxication of nontarget vertebrates, including blackfoot ferrets (Mustela nigripes), is remote.

Presented by Howard P. Tietjen, Wildlife Biologist, Denver Wildlife Research Center, Denver, Colorado 
2: Did you feed a diet with zinc phosphide to see what your actual residue would be?

A: ifo, in other words you are saying is lacing the diet itself with zinc phosphide, no, Just the zinc phosphide that could be present in the prairie dog.

l: I don't suppose you know the certain groups of birds that may be praying on these prairie dogs?

A: This is a potential, especially to scavengers like the buzzard. Buzzards have the ability to regurgitate. There is a strong background of information on the effect of poison nutrients on buzzards. You can't kill them with zinc phosphide. We made them so sick that they just barf it up. As far as the raptorial birds are concerned one of the things that saved us there, we find very few dead prairie dogs on the ground. I think there was only one instance which I will get into later, where we found large numbers of dead prairie dogs on the surface.

2: Did you sacrifice these after each trial to see if there was any zinc phosphide residue in these?

A: We did not analyze for residue. The only thing we ran was just gross analyses. I honestly can't say what we might have expected to find in the way of residues, but I doubt there would be very much.

2: Has there been research to determine cost definitive damage being done by the prairie dogs?

A: Not yet, in a way it almost sounds like a cop-out, but our motivation for getting into this program without having the immediate background information was very simple. We knew that the control operations were going to be carried out no matter what background information we had in the justification of prairie dog control. This is a very emotional issue, you can talk to farmers and ranchers and you can get a full gamet of pro and con on whether you should control or not control. But the fact remains that for many states they are still using strychnine and 1080 to control prairie dogs. This was something we wanted to get away from. We felt that there was enough justification for this research without the economic background at this point in time to develop zinc phosphide as soon as we could, or to evaluate it as soon as we could to see if it could be developed. l'e are in the process at the present time, in an interagency program with the U.S. Forest Service out of Rapid City, a very comprehensive research program, to determine just what this means in terms of cost and what prairie dogs are doing in some of our mid-short grass prairies.

Q: What is the Department of Interior's position on allowing this data for use by otner state agencies for state registration of zinc phosphide?

A: As far as 1 know, it's public record right now. This material right here is available to anybody who wants to use it. Now if you were a private agency and had developed this data, it would cost you money to obtain it. That is, there would have to be a settlement. As far as I know, it is generated by a Federal agency it immediately becomes public record and anybody can use it. Herb, ans I right on this?

That's right. A private formulator ivould want to be careful on hav recent the data is. We had a family size operation in Washington state which copied an old Fish and Wildiife label for orchard mouse control. Cne item it also had on it was also gophers, that's what he put on his label. All at once, last 
year, he had a $\$ 1,000$ fine levied on him, because EPA in running their tests found it wasn't effective on gophers. Of course, no one bought it for gophers, they bought it for mice. He pleaded his case and spend quite a bit of money traveling to the regional office trying to explain that he copied it off a label of the U.S. Fish and wildlife and finally they agreed to bring it down to $\$ 300$. 


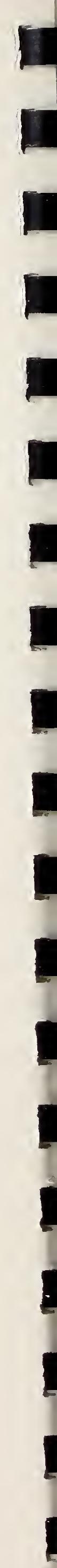


Thank you very much and good morning ladies and gentlemen. It is a pleasure for me to participate in this pesticides seminar. I bring you greetings from Mr. John Ritch, Director of the Registration Division, and native son of the "Big Sky State." He would have liked to have been with you for this seminar. However, previous comitments made that impossible.

I can assure you that I am happy to be here as Mr. Ritch's representative to talk to you about Registration Procedures and Evaluations. The subject is so extensive that 1 will proceed as rapidly as possible. I intend to cover five (5) specific points during the next 30 minutes or so.

1. A brief review of the Federal Insecticide, Fungicide, and Rodenticide Act and its recent amendment.

11. An overview of the Implementation of the Section 3 Regulations.

111. A detailed explanytion of the requirements for re-registration and registration.

IV. An explanation of the Classification Program for Pesticides.

V. A look at the organization that is to be used to implement the new requirements.

I have several visuals that 1 plan to use in this presentation and I hope that they will serve to help you follow my presentation.

Slide 1: FIFRA came into being in 1947 and has been amended several times.

Slide 2: The most recent amendment took place in Washington, D.C.

Slide 3: On October 21, 1972.

Slide 4: The FIFRA was amended by an Act named the Federal Environmental Pesticide Control Act of 1972. When referring to the Act, we now use the term FIFRA as amended. However, I will refer to the Act as "FIFRA" during the remainder

Presented by Herbert S. Marrison, Chief, Insecticide-Rodenticide Branch, Registration Division, OPP, EPA, Washington, D.C. 
of this presentation.

Slide 5: Although there are a number of changes brought about by the 1972 amendment, I will be speaking only of the re-registration, registration, and classification procedures involved.

Allow me to clarify the Division's position on the impact of the re-registration, registration and classification process as set forth in Section 3.

Let me first emphasize that the regs by and large carry forward existing registration procedures and criteria. While the rulemaking is somewhat complex, it is not going to generate any major upheavals.

We, in the Registration Division, recognize that there are those vitally concerned about the impact of the new regulations may have on either the pesticide they produce, or the benefits they have derived from the use of one or more pesticides. We also believe that each of us is interested in personal health and the vigor of our natural environment. The writers of the Section 3 Regulations have taken both concerns to heart, and have attempted to assure the availability of pesticides as well as a healthful environment for America.

Picture our growing problems if you will, just from the growing usage standpoint. First, the Federal Insecticide Act was passed in 1910, only 50,000 pounds of pesticides were being applied, and then consider that in 1947, when FIFRA was enacted, 800,000 pounds were being applied, and finally in 1972, over 1.2 billion pounds were applied. We have a different picture than one that may ordinarily be discussed.

We, in the Registration Division, have committed ourselves to getting the job done as quickly and with the least hassle possible.

Having had deviated for a moment, let me go into re-registration, registration and classification under section 3.

Slide 6: There are three basic tools for implementing section 3.

Slide 7: 1. The Section 3 Regulations.

Slide 8: $\quad$ A. Effective Date - August 4, 1975. 
Slide 2: $\quad$ B. Basic Regulations Content

Slide 10: Guidelines and Guideline Content. The Guidelines are only proposed at this time.

Slide 11: 3. Batch Guidance Package.

Slide 12: Which product must be re-registered? All products currently registered must be re-registered, cancelled or exempted.

Slide 13: How registration can be accomplished? This is to be done

Slide 14: through the procedure we call the Batch Process that takes

Slide 15: into consideration the grouping of products.

Slide 16: The "call in" procedure is to be published in the Federal Register very soon. This will call in the rebuttable considerations first.

Slide 17: The General Guidance Package is the basic instrument to communicate the re-registration process to the registrant.

Slide 18: The specific Guidance Package is to be used to inform the

\& registrant what specific requirements must be met for each

Slide 19: of his products to obtain re-registration.

Slides 20 to 22: The Specific Guidance Package contents are as set forth on the slides.

Slide 23: Let us look at the question"What data are required?" Section 3 Regulations set forth the need for data under re-registration and registration and there are differences. I plan to show the requirements and point out the differences .

Slide 24: First, let me show you what we are doing about re-registration data. Slide 25: 1. Determination of data requirements.

Slide 26: 2. Out come of data review by Division.

Slide 27: To continue, I plan to speak of the data requirements and how they correspond to either registration or re-registration as shown on this slide. 
Slides 28 \& 29: (Data Requirements Titles).

EFFICACY DATA $\quad 162.8(\mathrm{~b})(2)$ - New Registrations

Slide 30: Data are required to substantiate the effectiveness of a pesticide product. This data will be demonstrated through laboratory and/or field testing procedures which simulate actual use conditions. I think it is important to re-emphasize the actual use conditions being simulated in the development of the data. If the conditions under which the pesticide is intended for use are not simulated in the laboratory and field studies, a meaningful evaluation of the effectiveness cannot be made.

Laboratory Testing - You're on your own.

Field Testing - would require Agency approval under the provisions of an experimental permit.

(1) Minimum effective dosage

Effective dosage range

Rather than just the effective dosage and dosage range this information is obviously necessary to determine and assure that the correct dosage range have been set for a particular pesticide product.

(2) Application Techniques

(a) Equipment

(b) Method

(c) Timing

(d) Site

(3) Evaluation of activity against pests.

Does the product actually destroy, repel or mitigate to the pest for which

it was intended.

(4) Phytotoxicity or other non-target effects.

Measurement of toxic effects to plants or animals that are host to a pest

(this information has customarily been required of applicants in the past when appro- 
priate or relevant).

\section{Slide 31 \& 32: \\ GENERAL CHEMISTRY \\ NEW REGISTRATION}

A. Technical chemical

(1) Complete composition.

(a) Chemical names and \% of impurities

(b) Agency realizes that even the best methodology may leave a $\%$ of an impurity unidentified.

This can be approved on a case by case basis if:

Best methodology was utilized

Use would not be expected to cause any adverse effects on man or the environment.

(2) Basic Manufacturing Process

(a) Agency is not trying to regulate quality control

(b) Required by statute to determine exact composition

(c) During the manufacturing process, contaminants may be introduced into a pesticide unintentionally which may cause unreasonable adverse effects on the environment.

(d) Information also required before issuance of an EUP; data have also been required under 1947 FIFRA.

(3) Purity of starting and intermediate materials used in manufacturing process.

(4) Physical and chemical characteristics of active ingredient.

(5) Analytical metinods for principal component and impurities.

B. Specific Formulation.

(1) Complete composition

Name and $\%$ of each ingredient (active or inert)

(2) Basic manufacturing process

(3) Storage stability data

Expected shelf-life period

(4) Method(s) of analys is for identifying and quantifying the active ingredient(s). 
A. Outdoor application only

(1) Field stability data

(2) Persistence, Degradation and accumulation data for target and/or non-target species for the active ingredient(s), metabolite(s), or degradation products.

(3) Mobility data for active ingredient(s), metabolite(s), or degradation products including volatility and leaching properties.

B. All Products

Safe methods for disposal of the formulation and container.

slide 34

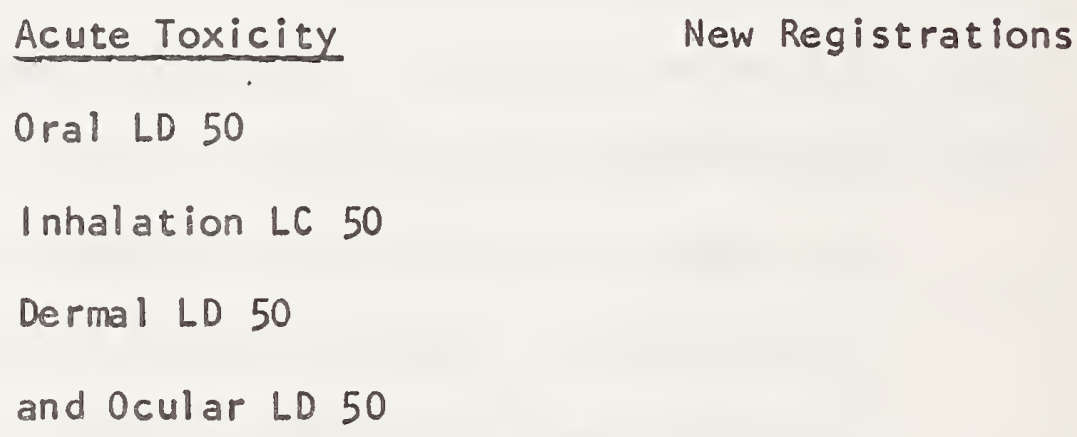

Slide $35 \quad$ Subacute and Chronic Toxicity Data

Both required as specified in the registration guidelines; may include assessment of the effects listed.

Oncogenic - To produce or induce benign or malignant tumor formations in living animals.

Mutagenic - To induce changes in the genetic complement of either somatic or germinal tissue in subsequent generations.

Teratogenic - To produce or induce functional deviations or developmental anomalies, not heritable, in or on an animal embryo or fetus.

\section{Slide $36 \quad$ Hazard to Non-Target Organisms - Both}

(1) Acute and subacute toxicity to avian species

(2) Acute toxicity to Fish

(3) Data to evaluate hazard to other non-target animals as specified in the registration guidelines. 
Products for outdoor application.

(1) Avian reproduction studies

(2) Aquatic invertebrate acute toxicity testing

(3) Aquatic orgarism life cycle studies

(4) Simulated field testing

(5) Field Monitoring and Observation

slide 38

slide 39

slide 40

$$
\text { Disposal Data }
$$

Re-entry Data (Cholinesterase)

Other Hazards
Both

Both

Both

A product that is a candidate for general use may be classified as restricted based on a number of other hazards not specifically addressed by the classification criterla (quantitative acute toxicity, qualitative exposure). If an evaluation of these hazards indicate that a serious hazard exists to man or the environment which can be prevented by restricting the use of the product, then the product will be so classified.

(1) Human Toxicological Data Epidemiological Studies

(2) Use History

(3) Accident Data

(4) Monitoring Data

Primarily applies to products previously registered; evaluation on a case by case bas is.

Classification is an intricateral part of re-registration and registration under Section 3. The purpose of this mechanism to restrict the use of hazardous chemicals to certified applicators and give the general public confidence in thos products available to them. 
The Act, simply stated, specifies that general use products will be those for which label directions and precautions are adequate to protect the public, whereas restricted products will be those for which additional regulatory controls are needed.

(1) General Use

Anyone can use; the general publ ic

(2) Restricted Use

Can be used only by certified applicators

Requires more knowledge and care

Slide 42

Classification of Pesticides Should

(1) Reduce misuse and accidents

(2) Correct "all or nothing" approach of the 1947 FIFRA. Now for the first time the Agency can control and regulate the use of a pesticide. Remember "it is unlawful to use a pesticide in any manner inconsistent with its labeling." Among other things, the classification process can more reasonably assure the proper use of a pesticide. It may, therefore, enable a particular pesticide to remain registered, whereas in the past it may have been subject to cancellation or suspension.

slide 43

$$
162.11(c)(1)
$$

\section{CLASSIFICATION CRITERIA FOR NEW REGISTRATIONS}

A. Domestic application - candidates for restricted use

(1) Dermal \& inhalation - categories I \& 11

(2) Eye - corneal opacity reversible within 7 days irritation persisting for 7 days

(3) Skin - severe irritation at 72 hours

(4) Acute oral LD 50

$1.5 \mathrm{~g} / \mathrm{kg}$ or less on the formulation as diluted for use

B. Nondomestic application - candidate for restricted use 
(1) Dermal \& Inhalation - category I

(2) Eye - corrosive; corneal opacity not reversible within 7 days

(3) Skin - corrosive to the skin

(4) Acute dermal LD50

$16 \mathrm{~g} / \mathrm{kg}$ or 1 t.ss on the formulation as diluted for use as a mist or a spray.

Slide $44 \quad$ Classification Criteria For New Registrations And

\section{Previously Registered Products}

Outdoor application

Candidate for general use

(1) Must meet criteria set forth for domestic or nondomestic application, as appropriate.

(2) Residue - immediately following application in or on food or feed of mammal ian species.

(3) Residue - Avian species; in or on feed or food immediately following application.

(4) Water - aquatic organisms

Maximum calculated concentration.

Slide 45: Tox Cat Table

Slide 46: Graphic on Tox Cat for Nondomestic uses

Slide 47: Graphic on Tox Cat for domestic uses

Label will look different. Her is an example of the

Slide 48: general label and

Slide 49: restricted label

Our review will result in either a

Slide 50: reject or a

Slide 51: Acceptance and we will do what is possible to have the latter stamp put to the registration application or re-registration application.

You may be asking, how will all this get done and who will do it. I will close 
this presentation by answering that question for you. Our recent re-organization was engineered with this job in mind and this is what it looks like.

Slide 52: Workload in $73-74$

Slide 53: Division organization

Slide 54: Chart of processing of applications

Slide 55: RET functions

Slide 56: PM functions

Sijde 57: Science review functions 


\section{Re-entry Studies in Washington Orchards \\ and \\ Monitoring Pesticides in the Columbia River Basin}

For many years, there have been federal I aws and regulations which were designed to control the distribution and use of pesticides. These laws and regulations, unt il the last few years, have largely dealt with protection of the applicator and the consumer. However, recently regulations have been enacted which are designed to protect farm workers from harmful pesticide exposure. As a result of arthropod resistance and the ban on usage of many of the more presistent chlorinated hydrocarbons, we have seen increased usage of the organophosphorous pesticides. As you know, the organophosphorous compounds are normally broken down quite rapidly by the environmental processes in comparison to the long-lasting chlorinated hydrocarbons, However, the organophosphorous compounds as a class of pesticides have in comparison to the chlorinated hydrocarbons a rather high acute mammalian toxicity, and are inhibitors of the chol inesterase enzymes involved in transmission of nerve impulses in both arthropods and man.

THE TASK GROUP ON OCCUPATIONAL EXPOSURE TO PESTICIDES recently estimated that in California, $40 \%$ of the reported $11 \mathrm{mill}$ ion pounds of active organophosphorous ingredients were used on crops involving substantial contact by workers with plant surfaces. The earliest reports of workers becoming ill as a result of indirect exposure (contact with plant surfaces while thinning or picking) appeared in the late 1940's as parathion was introduced, especially in the citrus groves and grape vineyards. Quimby and Lemmon, in 1958, reported five outbreaks among farm workers from 1952 through 1957 in Washington State resulting from exposure to parathion (0, 0-Diethyl 0-p nitrophenyl phosphorthioate). There were additional cases in 1958 and the number gradually tapered off. Since 1961, there have been no confirmed cases

$\bar{P}$ resented by Lynden P. Baum, State of Washington Department of Social $\varepsilon$ Health Services, Regional Pesticide and Chemical Laboratory, Wenatchee, Washington 
in Washington of pesticide poisonings due to farm workers having contact with the fol iage in orchards.

One of the approaches taken to minimize exposure to organophosphorous compounds among orchard workers is the concept of establishing re-entry periods. The Federal Task Group on Occupational Exposure to Pesticides defines re-entry period: "A worker re-entry period is the time interval that must elapse between the date of application of a specific pesticide to a specific crop and the date when workers can safely enter the treated fields to perform their cultural operations."

Several yeras ago, national regulations were proposed for establishing re-entry periods. These regulations became immediately the subject of controversy as it was felt that they were being proposed without looking at sufficient research data. The setting of realistic re-entry times is complicated by factors such as type of pesticide, its formulation, amount applied, crop, weather, gersgraphic location, and other factors. As an example, it was felt that the proposed establishment of a 14day waiting period for the pesticide, guthion (azinphosmethyl) was not a realistic interval for the State of Washington peach and apple crop. This material was being used in Washington with a much shorter re-entry period with no known heal th problems due to exposure of thinners or pickers. As a result, in 1973, the Washington State Department of Social and Health Services, Washington State University, Washington State Department of Labor and Industries, and the Environmentil Protection Agency's Research Station in Wenatchee undertook a joint research project to determine if the then current practices in Washington were safe or whether a potentialffor pesticide illnesses was going undetected.

Two Wenatchee orchards were chosen for the project in which guthion had been sprayed on peach and apple trees during the thinning season. Six orchard workers ( 4 men, 2 women) were employed in orchard " $A$ ". Medical and pesticide exposure histories were obtained on each individual. Two pre-exposure blood samples from all individuals were obtained for chol inesterase determinations and a urine sample from 
the male workers was tiken for organophosphate metabolite determinations prior to exposure. For the first six working days after thinning commenced, these individuals entered and thinned a section of apple orchard that had been sprayed the previous day with guthion ( 3 lbs. 50\% WP/acre). During the first exposure period, samples of blood and urine were collected at the end of each working day. Research personnel also monitored the thinning areas during the working hours to gather information regarding the types of protective clothing worn by workers, duration of work, weather conditions, and other pertinent information. Workers were also observed for any signs or symptoms of organophosphorous poisoning. Wo such symptoms were observed. Air samples and tree leaf samples were collected periodically from the areas near where the thinners were working.

Slight variations did occur in the cholinesterase levels of the RBC's and plasma, but remained well within the normal limits and were not clinically significant. Phosphate metabolites in the urine increased fron nondetectable levels (less than $0.01 \mathrm{ppm}$ ) to values greater than $2.0 \mathrm{ppm}$ as the thinning progressed, demonstrating an accumulative effect. However, there was no relationship between guthion metabolites as measured in urine and the cholinesterase values. Both Dimethyl phosphate and Dimethyl thiophosphate metabolites disappeared rapidly from the urine once exposure ceased. At orchard "B" a similar program to that of the first orchard was followed. Nineteen individuals were involved in thinning peaches and apples. Guthion was applied to the peaches and apples at a rate of $2-1 / 21 \mathrm{bs}$. of $50 \% \mathrm{WP} / \mathrm{acre}$. Blood and urine samples were taken prior to exposure and at the end of the third and seventh working day after spraying of the peaches. It required ten days to complete the peach thinning after which the workers were then out of the treated orchards for one week prior to apple thinning. A blood and urine sample were collected one day prior to again entering the treated apple orchards, and samples were collected on the fourth and eighth day after spray was applied to the apples. Unfortunately, nine of the group left to pick cherries, leaving only ten persons to thin apples. 
The plasma chol inesterase level was up $(\bar{x}=+.19$ sign. $<1 \%)$ a statistically significant amount at the three day residue age while the red blood cell acetyl cholinesteras level $(\bar{x}=<-.56$ sign. $<1 \%)$ was down a statistically significant amount. The mean difference for plasma cholinesterase was not significantly different from zero at residue age seven days while again the red blood cell acetyl cholinesterase level was down $(-.76 \mathrm{sign} .<1 \%)$ a statistically significant amount.

When a comparison was made of the tem persons who picked apples, the mean difference between pre-exposure and exposed levels were obtained and tested. None of these means were found to be statistically different from zero.

Although statistically significant mean decreases in red blood cell cholinestrase were found in thinners working in the peaches this mean decrease was less than one unit (approximately 5\%). In no case did a worker's cholinesterase decline a clinically significant amount. Also, there was no statistically significant difference in cholinesterase levels between the pre-exposure to peaches sample and the pre-exposure to apples blood sample.

Participants in the program were questioned regarding any health problems whenever blood and urine were drawn. The following problems were reported:

1. Headach - 2 individuals

2. Rash due to peach fuzz; rash due to poison oak; hive-like rash on cheek and neck for one day - 3 individuals

3. Upset stomach unrelated to pesticides -2 individuals

4. One individual thought the spray residue caused a tickling in his throat making him cough.

Some of the symptoms reported are compatible with symptoms of organophosphate poisoning, i.e., headache and upset stomach. However, in view of thie fact that chol inesterase levels were not depressed and no one experienced any clinical signs of poisoning, we feel that these symptoms were not the result of poisoning.

Al though the guthion metabolites, Dimethyl phosphate and Dimethyl thiophosphate 
increased sharply during exposure, the levels were not accompanied by recognizable illness or decline in cholinesterase values. Residue on leaves decreased from 3.65 micrograms guthion $/ \mathrm{cm}^{2}$ directly after spraying to $1.58 \mathrm{micrograms}$ guthion/ $\mathrm{cm}^{2} \mathrm{two}$ weeks after spraying. Residue levels in the air also decreased rapidly from 69 micrograms guthion $/ \mathrm{m}^{3}$ io $12 \mathrm{micrograms}$ guthion $/ \mathrm{m}^{3}$ by the third day after spraying.

It is concluded fiom this study that the exposure of these two crews in the manner described here did not result in adverse effects on their health detectable by the methodology employed.

A similar study conducted in 1974 has produced results that are almost identical.

This year (1975) we followed 23 people through their normal working routine between June 17 and July 23. We acquired both blood and urine samples twice a week including three pre-exposure samples and the mean values for all workers did not extend beyond the range of pre-exposure values.

Thus, we feel, from the information gathered in these studies, that additional information is needed for each pesticide, and that such factors as geographic location must be taken into consideration when establishing re-entry intervals.

In January of 1974, the Health Services Division of the State of Washington and the Bureau of Reclamation entered into a joint agreement to monitor pesticide residue levels within the Columbia Basin Project. The project is located in the south central part of Washington State. It encompasses 526,628 acres with another 250,000 to be added in the near future. Eventually, the project will have one million acres. The project contains 5,812 farm units and 19 public wildife recreation units.

There has been a history of extensive use of pesticides within the Basin. However, prior to this time, no residue monitoring has been attempted in the Basin area.

The objectives of the program were: (1) to determine if measurable amounts of pesticides do exist in the irrigation canals; (2) to identify major types and determine their concentrations; (3) to assess the impact of observed pesticides levels on the health of the general population, environment, and agriculture of 
the area.

Irrigation water and rainfall penetrate very effectively through the soils in this area. The vast network of canals which pass through the farm lands, coupled with the history of pesticide usage raised a concern for possible contamination of run-off water. Water and sediment samples were taken routinely at ten sampling sites. Analyses are conducted for twenty-five different pesticides. This includes twelve chlorinated hydrocarbons, $n$ ine organophosphorous compounds and four other compounds. In 1974, ten of one hundred ten samples contained pesticide residues and in 1975, thus far, twenty-two of seventy-four samples have been positive. We feel that the increase in 1975 was primarily due to breakdown products of DDT which were showing up. Other residues found were dieldrin and thiodan 1 . The highest concentrations of $P, P^{\prime}-D D E$ has been $85 \mathrm{ppt}$ and $34 \mathrm{ppt}$. The $85 \mathrm{ppt}$ of $P, P^{\prime}-D J E$ was found only once. When we resampled that same location, the $P, P^{\prime}-D D E$ was not found. The highest thiodan and dieldrin residues found have been $26 \mathrm{ppt}$ and $55 \mathrm{ppt}$ respectively. Available data for sediment samples indicate a decrease in residues for 1975 compared with 1974. Soil properties, micro-organisms, leaching, and restrictions placed upon the use of dieldrin and DDT may be responsible for the decrease in residues. The sampling program will continue through 1976 and hopefully wil: be funded past that dàte. 
Q: Whatppercent budworm mortal ity did you achieve with Dipel?

A: We are not complete on data analysis, we are still analyzing the data. It gives us some ideas as to the results we got. The Canadians have made 95 percent mortality with a pound and with a half pound using the exact formulations of Dipel that we are using.

Q: What was the gallonage per acre?

A: It was one pound for two gallons per acre.

Q: I have two questions. 1. The Canadians are using a lot of fenitrothion, has the project at Berkley evaluated fenitrothion?

A: I don't think we have. Fenitrothion was tested this year at Oregon and 1 have not heard the results of the tests.

Q: What about the nuclear polyhedrosis virus?

A: Nothing on budworm, with Tussock moths, yes. I think the Canadians are doing some studies with viruses, but as far as the pilot testing, we don't have anything.

Q: From the time the material is applied till the time you get the highest mortality, what is the length of cuttoff, how long?

A: Twenty-one days. There was not a lot of difference from the fourteen day samples and the twenty-one day samples, not as much as from seven to fourteen day samples, if 1 remember right, but there was additional mortality between the fourteen and twenty-one day samples. Now we do plan to go back in and we will be sampling these areas for egg mass samples. Sampling again next year to see if we can find a difference in parasitism. An area was sprayed near Missoula in 167, working with a Berkley group, we found an increase in parasitism for one and two years after we sprayed with Zectran even above the levels which we found the year we did spray.

Q: Do you have any explanation for that?

A: No, other than unless the budworm population is reduced to a point that the parasties can get the upper hand.

Q: Through your evaluation, have you been able to carry out a study which would essentially allow you to develop a model of budworm damage in relation to retarded tree growth to allow you to make some sort of economic evaluation of the impact of your treatment?

A: We have had two studies and there is one going on this year. One was done by Wayne Bosefied on the Flathead Indian Reservation. It was quite an intensive impact study, but not to the extent they are doing this year on the Nez Perce Forest. The summary of those is as much as 26 percent loss in board feet per acre. A tolerable level of budworm in relation to how much damage we can stand is, I don't know what it is. Now there is a group at the PNW station who has done a lot of work on impacts of western spruce budwormaand they are still analyzing the data, this isn't available yet. 
Q: You mentioned that the study on birds was terminated after five days. Were all studies on insecticides terminated?

A: No, that was just the brain cholinesterase part of the study. Dr. Heney told me that they were having a greater impact with the shooting than they were with the pesticides, so they decided to cease and desist.

Q: Will the population studies continue for a year or two or three to see what the long-term effects would be?

A: I really don't know. I could find out. Mark, do you have any idea? I thought they would be over in 45 days. Some of the same people vho were working with Dr. Heney were working on the DDT project last year and were going back and forth, but 1 understand this was going to be 45 days. When 1 talked to him just before he left, he had no idea.

Q: The reason why 1 ask is because of the greatest impact from the other studies is the indirect effect from the water pollution cause.

A: Well Sevin, depending upon what study you look at, it runs from twenty to forty days in the environment and Dylox from the best evidence we have today, is just about gone. It's down to $2 \%$ of the dose applied in about seven days.

Q: When do you put these insects as far as diagnosing the problem? When is the best time to survey them?

A: Well, the Forest Service normally conducts aerial surveys of all forest areas and they pick up defoliation and, in fact, we've just completed our defoliation survey. After we've spotted an area from the air, we go in and check from the ground to see what insect is causing the damage. So there is a lag of about a year, perhaps more, before you start picking up visible defoliation from the air.

Q: Do you use infrared?

A: I come from the southeast area and we have been using infrared photography down there for a number of years. It works fairly well on bark beet le where you get a distinct color change. For those of you that are not familiar with infrared photography, its original value looked like we might be able to pick up pre-visual symptoms of diseased or insect attacked trees. That did'nt prove to be the case. It offered a distinct advantage, I think, in that with a photograph you have known plot sizes and you get a fairly good statistical estimate of your damaged area. 
Q: What experience does EPA have in agricultural chemical applications?

A: Last spring, we went through some excersises answering some 127 questions proposed by the Congress and one of those questions was: "Within the office of pesticide programs, what is the composition of personnel?" We gave the Congress figures on how many $P h . D$. agricultural background individuals we have, I don't recall the numbers but expertise is there. Primarily it's there in the Registration and Criteria and Evaiuation Division in terms of the technical degree people. The Deputy Directop of the Operations Division is a man by the name of Dr. Fred Whitamore, who is, if I have my information correct, was chief entomologist, U.S. Army, before he retired. He also has had two years with WHO and eight years with FAO over in Rome in medical entomology and also agricultural work. Administrator Train supposedly has taken some steps that will assure other imputs into the decision making process in the area of pesticides in EPA.

Q: What 1 am getting at is that from practical application and research, from what 1 can see, you have no realization between research and practical application of the products or the realization of what you guys do with the products once you get it in the field.

A: In terms of the certification program?

R: Right

A: That's the criticism that we have heard. I don't totally discount it or totally disagree with it.

Q: Do state people act in an advisory capacity?

A: There is a group cailed SFIAC, State Federal FIFRA Implementation Advisory Committee, which each region in the country, the committee, as 1 recall, is composed of the ten EPA regions by representatives at the division level or in Region VIII's case it's anyway they're EPA people. The states in any particular region are asked to elect a representative to represent that region at the SFIAC meetings. In fact, we just had one two weeks ago and those fellows were not all that kind to the Agency, this was a week or two after the Chlordane-Heptachlor incident. There are some real problems, but hopefully we are involved in this public participation process and they are addressing those concerns that you just voiced in terms of products versus the actual use situation. One of the greatest criticisms that the Agency has encountered for the past 18 months is where's your restrictive use pesticides list.

Q: Why is there separate consideration of the Indian nations since they are within a state(s)? Why is it necessary to consider them individually?

A: There are Indian reservations in the United States that are under state jurisdiction and there's an option presented in the state plan regulations. 1 don't know the rational behind some of these things. Let's talk about the Indians, but it was a hot issue when the state plans were being developed and I work in the east tower and the west tower insisted on it and that was where Train lives, so the west tower speaks and the east tower does.

Q: That's why I was wondering, because in our state we have never had any trouble with them fitting into our state plan and now the Indians are really getting up set, they are not about to sign anything with anybody. They fit very well into the state boundaries. You start asking them to sign certification plans 
why they say this is the first one we ever signed and we're farther from that than 50 years ago, that's why I was wondering why is there a need for a separate plan, when they are al ready with in a plan?

A: There is not, if they agree to be within the Washington state plan.

Q: They say we won't make any agreements, we don't have to. They are still certified, all they do is attend the meetings, they come in and buy pesticides. I can't see where there is any quite like that interjected in them, because it works the way it is.

A: If that's the way it is displayed in the Washington state plan...

Q: No, it won't be. They won't be mentioned, but they are citizens like everybody else and they just walk in the store and buy the pesticides after attending this meeting. I can't understand where the need stands.

A: I don't know the rational behind it. We got the concession that if the Indians want to add on to the existing state plan, that's fine. If they want to go ahead and the Indian governing body decides to develop their own certification plan, then that will have to be submitted to the B.I.A. and the B.. .A. then gives it to the EPA for review and approval and goes back through the B. I.A. and it kind of works that system. But if you have a real good working ralationship with your Indians, I don't think it is our intention at the operations level any, is to do violence to any working system that works, it just doesn't make sense. Bill Homer, who is the division director, is opposed to screwing up something that works, because we have to do something else. In fact, Jim White, who is my branch chief, was just out to Washington a couple weeks ago and I think we feel that whatever is written, the Washington state plan is an approvable plan, what we

$k$ need now is a government signature on it.

Q: It doesn't address itself to the Indians, I mean they are just like everybody else.

Q: Jim, I was going to ask you if you know what minimum spacing will be required following certification and do you have any ideas on that?

A: I really couldn't conjecture on that, I don't know. This comes under the maintenance of state plan category and I think most of us would prefer to defer that until we get these things operational until we get certified applications and then we will have the state enforcement actions, the misuse provisions of FIFRA and those things to contend with. That's a year probably two years away and if things keep going the way they are, I expect it will be a state option to excercise that equal effect. How effective are the regulatory programs already in operation?

Q: I think the main problem that we are talking about on the Indian reservations in Montana that Ed and I found working on reservations in Montana is not certification of applicators, but who has the enforcement right within the boundaries of that reservation. Can state agricultural personnel go in and carry out enforcement action without the Indians' consent, that's the big hang up in Montana. It's not certification, but the enforcement of law.

Q: Are the Indians now under the MPA (Montana Pesticide Act)? For use in enforcement purposes?

A: Yes, for enforcement purposes, but 1 don't know how they feel about it. 
Q: Do you issue experimental permits for testing of a particular material?

A: Not from the regional office.

Q: That is all at the national level?

A: Correct

Q: Why would it not be better at the regional level, it would seem to me that this would be so much easier?

A: Two reasons: Experimental permits are part of the product registration process and registration is on the national level. Secondly, since the two are so closely related, you have to have uniformity across the nation and if you divide it up on the regional level, you would lose that uniformity.

Q: It seems to me that the western United States is duplicating the Washington state program in setting up national pesticide regulations. You're just duplicating what the western states have al ready done. You're no help to us at all. You are just putting roadblocks in what we are trying to do.

A: In that the Federal law itself is the roadblock, it can be viewed in that manner. My job is to help you bring your regulations into conformity with Federal law.

Q: Yes, but there was a time when federal law was out. At that time EPA wasn't in the leadership. Now if a state does not agree with EPA, EPA will not recognize their program and it could be a good program. If you don't conform with EPA, then you'll never get your program through. It doesn't matter how good it is.

A: That's true, but there are very few incidents where bringing a state program into conformance with the federal program has reduced its effectiveness or made it less desirable type program. Do you have any specific instances where we have, 1 mean I would be interested in hearing them?

Q: I could give you a list of about 150. I don't know what is going on here, we have gone through this and really the programs of EPA have not helped the programs at all. They create roadblocks and the chemical industry is 20 years behind time.

A: My experience is, it depends a lot on who you talk with, as to how the federal law effects the nation. Without any specific point 1 can't argue one way or the other.

Q: You can't go on specifics because EPA talks in generalities. At least in Oregon and California experiences $\mid$ have been associated with, I say that the western states showed great leadership and the states that are having difficulties didn't have the programs that these states had. 1 '1l admit that the federal law is a little binding on the other states, but 1 think that Washington, Oregon, and California had very good programs, they still have good programs. The national picture was probably diversly affected by the ir programs.

A: Are you saying their programs upgraded the national program?

Q: Yes

A: If the proposed budget goes through, now you gave the example of 39,000 that the 
state of Montana agriculture would receive. What type or grant would that be? What would the guidelines be for this grant?

A: The guidelines are very flexible, but if that has been promised, what is the intent? The intent is to implement certain cases to allow them to use the money for enforcement, testing, licensing, or hiring inspectors and secretaries.

Q: A field personnel office?

A: If that is what the state of Montana wants. We are not going to write the guidelines. One major restriction on this, is that they say this is for implementation for certification, they can't use it for parties you understand. I have this one major guideline I go by. I call up the state and ask them what they want and they tell me the type of program they want and I write the guidelines to say this is what EPA is going to require for this money.

Q: In Montana in 177, is there a chance of re-negotiating, will there be federal funding? Is that in the future on this or is there a proposed cutoff after next year?

A: There is no proposed cutoff with this funding. If Congress gives it to us, we'll give it to the states. Our hands are tied to that extent, we can't give if we don't have it. If we have it, we will give it.

Q: What happens if you don't get the funds appropriated?

A: If we don't get the funds appropriated, we can't give it to allow the states to carry out the certification program.

Q: Then what happens?

A: We'll have to wait and see. 
Q: How many people took the rabies treatment last year because of contact with rabid skunks?

A: I don't believe there were any that took it because of contact with the rabid skunks, these were all secordary exposures.

Q: Has anybody come forth in the defense of skunks, like there are a lot of folks around that defend the coyotes?

A: I can't think of anybody, particularly the seven people who went through the shots, I know that for sure.

Q: Have you had any problems with the rabid skunks not accepting the bait?

A: This is a difficult thing to evaluate in terms of the only way a person could... Are you referring to the fact that skunks approach the bait and then turned around and left without eating it, or are you talking about a skunk that broke open the bait, ate a little bit of it and then turned and left? Is that what you are referring to?

Q: Both of them are in the same area. What 1 was thinking about was one of the symptoms of rabies, as 1 understand it, is the fact that these animals are having muscular coordination problems. One of the things that is effected is their swallowing. Does this cause any problems?

A: Not that we were able to evaluate. We had an occasion in Fergus County in particular where we initiated control surveillance programs. We found several dead skunks just lying out in the pasture in the area, with the cause of death unknown because the skunks had been dead long enough where even collecting the head and submitting it to the diagnostic laboratory, they could not confirm the cause of death. In terms of the skunks demonstrating the clinical symptoms of the disease, particularly the latter symptoms which you are describing the ability to swallow, we weren't able to determine whether or not this influenced their ability to consume the bait.

Q: Was the evaluation made on whether or not there was a possibility of these populations of the skunk being balanced because they have such a high incidence of rabies by eliminating themselves?

A: There is a question here where a considerable amount of research is going on concerning the incubation period of the disease. This is how it maintains itself throughout the winter months, when, hypothetically, contact would be cut down due to adverse weather conditions. Whether or not we have the "Typhoid Mary" type of situation where we have an animal that could be a carrier, for either an extended period of time or perhpas through its entire life. It could maintain the disease with fluctuations in the population, perhaps influencing the spread through the area is yet unknown. There is a great deal of work needed in the epidemiology of the disease necessary yet before any final determination can be made on that.

Q: Aresskunk rabies transmitted only by a bite from the rabid animal?

A: The entry of the virus itself can occur through a bite wound, it can occur through a sore in your hands, so in terms of an actual conflict between a person... We had a couple of guys chased around their back yards in their underwear in the middle of the night by a skunk and everything else. It would not necessarily take a bitting wound. For example, this case of calf rabies resulted from contact with 
the saliva of the animal through, it could be resulted through a sore on the hand, that's all it would have taken.

Q: Just one point on this, in two or three instances where rabies have been transmitted through the air by the virus being carried on the guano.

A: That was in bat rabies, wasn't it Dale?

Q: Right

A: Yes, aerosol transmission in bat caves. 
Q: Has the use of $M-44$ reduced livestock losses? is the $M-44$ the only control tool for controlling the coyote population?

A: In terms of controlling a population, no. In terms of control, we are probably talking in terms of 75 to 80 percent of those coyotes or fox in that area, no. But with all control methods it is very questionable whether we are reaching that in any area. Except in Montana in Carter County and Garfield County. When talking about efficiency in terms of stopping livestock loss, our study is to run until October 15. We have monthly report forms coming from probably eight to ten counties on their monthly loss by all causes, predator, disease, weather, whatever and what we need to do, of course, is parallel that with the control tools that are being used in the field. Our study was control tools of all types plus the addition of $M-44$, what effect does it have? We have control and experimental areas. I car't give you any data on that because we have not planned to release that or evaluate that until the end of our program. We have answered one pphase of our study, the relationship to nontarget species. I think we have shown a very specific result. As to livestock loss, preventing a livestock loss by using the $M-44$, we cannot answer that question at this time.

Q: Ken, you said something about a very serious dog problem?

A: Yes, in some communities. Willard would be a prime example, it is right next door, they have a small sheep producer, they had a small problem. I think an excellent example of that, however, would be south of Missoula, in Florence, where a sheep producer was told his problem was dogs, but they ran a research project this year on this by the Department of interior and they did an excellent job. They showed all of his problems were coyotes.

Q: How many dogs were taken with the $M-44$ program?

A: We took four dogs, two were predatory in nature, two dogs had strayed into the ranch, they were the producer's dogs.

Q: How do you mark your sites out in the bush? Do you have a system?

A: Yes, we have a field diary. In that field diary they place the date, the date they placed them, and the location, how far from the ranch boundary.

Q: Is the area posted or something?

A: Yes. In addition to that we have warning signs. We also have a stake warning sign, which is a survey stake with an arrow on it that will point you right at it and within 25 feet of the device there is a warning sign that says danger,

Q: This question of efficiency on the number of animals taken, perhaps there would be some interest in the results of the $M-44$ emergency use last year by Interior. could you give that report?

A: Yes, you mean where they reduced the losses by two to three percent?

Q: No, in the areas where damage was occurring, the percentage of losses that were stopped by the M-44.

A: Yes, that was a two to three percent figure. 
Q: No, I was thinking of a different figure, in the areas where it was tested, I believe 310 , if I recall correctly. Thirteen percent of the time, it stopped, it is the only device that stopped losses, $41 \%$ of the time was total ineffective and $46 \%$ of the area was tested was partially affected.

A: That's interesting because they didn't use those figures at the hearings in Washington, I would like to say one thing about the hearings that EPA had. I was very impressed, I was proud to I ive in the United States and of the administrative law judge that handles thepproceedings was outs tanding, he was fair, honest, they were trying to gather information that was true. Emotionalism was squelched at those hearings. One thing I still have of great concern was that the environmental groups are able to be represented by one attorney. In other words, eight, ten, or fourteen in this case of M-44 was represented by one set of attornies. One of them having their own. While other parties that enter, we have to be separate, we all had our own council, to join would be very difficult. It puts those who are registering products, which probably many of you here are aware of, in a very awkward and expensive position. Whereas those who can pool their money and have one attorney and he can speak for them all, it definitely saves time and money for them. of course, the burden of proof for a pesticide, in our case here, a predacide was on our backs so we had to do that. It's $n$ ice to be able to set back and ask lots of questions and eventually in anything when you break it down to scientific findings, I think it's very difficult to answer many of the questions today that we have regarding anything. If you get down to brass tacks, like the gentlemen was saying, outlines and designs, you would eventually get to that point with anything. I was impressed with EPA's hearings.

Q: Perhaps some of you may be interested in the current registration of the use of these on forest lands. I called back to Washington and they indicated that they weren't to be used on forest or recreational type places so I am not sure which interpretation is correct. 
Q: How did the federal contract tie in with the incineration work in Texas? Did this compliment this or was it of value in where you started from?

A: I'm not aware of this study. Where in Texas? I know that about six years ago there was three studies, two in Oregon and one incineration in Texas. There was an incineration study down at Mississippi State at about that point in time, I'm not familiar with anything done in Texas. The work at Mississippi state was at a laboratory scale, general. They looked at such things as the thermal gravimetric analysis to see at what temperature the compound might come apart. They did not look at the kind of things we were trying to address, and that is what is the specific operating condition we would use in the field to effect the degradation. We did utilize their laboratory results in helping us decide where to try to operate.

Q: Do the operating costs of incineration make it practical?

A: We get into a snag as to what is practical. If we go back to this slide showing a range of results for DDT, which have been researched, they can be arranged from .30 pounds/thousand to .02 pounds/thousand. I'm not sure who is in a position to determine if that is a significant difference. That same range represents a rather broad range of an operating condition, from 30,000 to extremely good. The only way that 1 know to evaluate the cost of what we did is in terms of the pounds of product that we burned with the dollars that we spent on our contract. You know when you're talking about $\$ 19$ pound you appreciate that there's quite a bit of analytical work involved here, that you normally wouldn't get.

Q: Did you try your experiment using red oxygen in your fuel system rather than compressed air?

A: No we did not.

Q: I understand that if you use air you process a lot of $n$ itrogen that goes out the stacks.

A: That's correct. When you burn with air you do get quite a bit of nitrogen through there and you do generate, well it turns out that the better job you do of burning things, the worse jcb you do in terms of nitrous oxide emissions. This is one alternative we did not look at. Our basic approach was to try to utilize in so far as was possible, off the shelf standards. The thinking was to come as close as was feasible to utilizing existing facilities of standard design criteria. We used this standard fuel oil burner like you probably have if you have a boiler somewhere, it's exactly the same design, we did not use more sophisticated burners such as the blue flame burners, such as the people in Canada utilize. But our overlying policy was to try to utilize the state of the art equipment, of the shelf equipment.

Q: The assured $99.99 \%$ efficiency is not an acceptable level, is it?

A: It was acceptable at the $t$ ime. I am sure there are people who will say that anything coming out of the stack is unacceptable, but one rarely gets $100 \%$ yield in anything.

Q: Are you familiar with the Aerolet Corporation?

A: Yes 1 am. 
Q; They say they have a $100 \%$ rating.

A: I'm aware of that. The results that we showed here in all cases included limits of detection or vapor components of the sample in which the actual pesticide was not detected. This is true as 1 already pointed out for Malathion, but it was also true for Atrizine and a couple of others. Again, that's why you can look at the data in the report and find a lot of "less than values" given. We took what we thought was a conservative approach to report the quantity that we could really evaluate which translated less than the detection limit. We were not in apposition to say that it was simply zero, just because v'e couldn't detect it.

Q: But, your emissions will not meet the air quality standards of almost any state that has that standard at the present time.

A: The emission from the stack, this is true. This is why emission control devices will be required. Even with theoretically $100 \%$ efficiency in burning DDT, you have still quite an amount of $\mathrm{HCl}$ coming out that is not going to meet anybody else's standards either, without some sort of control device. 
U: Did I hear you right, that if EPA does not, on an approven basis, fund this program, you will change the law?

A: iNo, we will not change the law. They will still take the written examination, but I won't say what kind of written examination it is. It'll show on paper that it meets federal minimum standards for private applicators. But in terms of the state of Montana going out and doing what 1 consider to be a halfway adequate job, we will not be able to because we won't have the manpower. I'm not going to hide this under a bushel basket, it's a fact.

Q: It isn't state law is it?

A: Oh yes, we must doiit by written examination. It doesn't say what the written examination is. The written examination technically could be two questions that the county agent has setting in his office. I mean that's a little ridiculous.

1: Could the certification program be handled by education only, to reduce the cost and manpower needs?

A: In the first place, I would be against any system for private or commercial applicators that is based just strictly on education. If you don't combine education with enforcement and evaluation, you don't have anything. We estimate originally that the cost for training, I think it was for both private and commercial applicators was initially $\$ 450,000$. Then our farm applicators would come back every six years for re-qualification either by taking an approved training course or by re-examination, whatever they desire. Commercial applicators will come back every five years for re-qualification either by examination or by a training course. 
